

\section{K R I T I K E \\ An Online Journal of Philosophy \\ Volume 12, Number 2 \\ December 2018}

ISSN 1908-7330
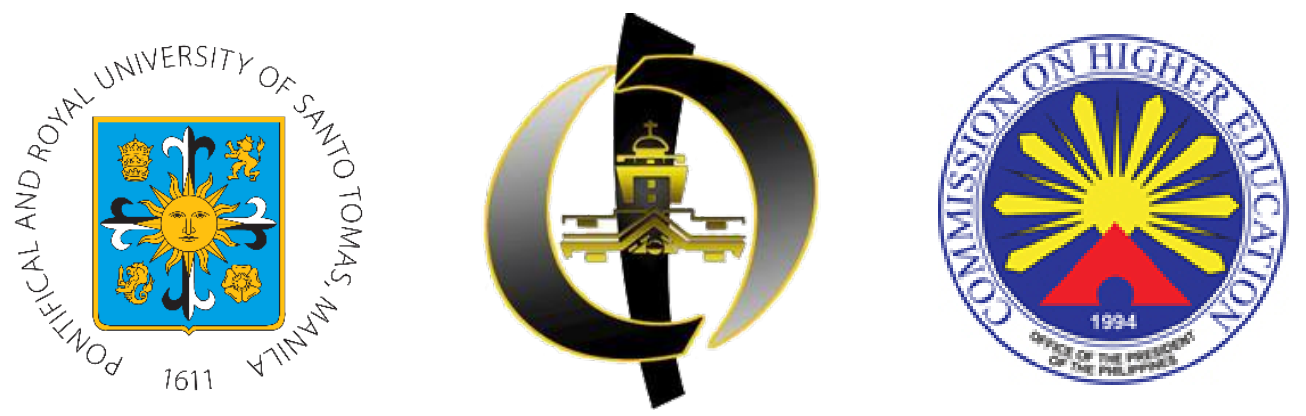

THE DEPARTMENT OF PHILOSOPHY

University of Santo Tomas

Philippine Commission on Higher Education 


\section{COPYRIGHTS}

\section{(c) (1) (5) \\ BY NC \\ All materials published by KRITIKE are licensed under a Creative Commons Attribution-NonCommercial 4.0 International License}

KRITIKE supports the Open Access Movement. The copyright of an article published by the journal remains with its author. The author may republish his/her work upon the condition that KRITIKE is acknowledged as the original publisher.

KRITIKE and the Department of Philosophy of the University of Santo Tomas do not necessarily endorse the views expressed in the articles published.

(C) 2007-2018 KRITIKE: An Online Journal of Philosophy | ISSN 1908-7330 | OCLC 502390973 | kritike.editor@gmail.com

\section{ABOUT THE COVER}

KRITIKE: An Online Journal of Philosophy, 12:2 (December 2018)

Roland Theuas DS. Pada, Parasol, 2018. Photograph. 


\section{About the Journal}

KRITIKE is the official open access (OA) journal of the Department of Philosophy of the University of Santo Tomas (UST), Manila, Philippines. It is a Filipino peer-reviewed, interdisciplinary, and international journal of philosophy founded by a group of UST alumni. The journal seeks to publish articles and book reviews by local and international authors across the whole range of philosophical topics, but with special emphasis on the following subject strands:

- Filipino Philosophy

- Oriental Thought and East-West Comparative Philosophy

- Continental European Philosophy

- Anglo-American Philosophy

The journal primarily caters to works by professional philosophers and graduate students of philosophy, but welcomes contributions from other fields (literature, cultural studies, gender studies, political science, sociology, history, anthropology, economics, inter alia) with strong philosophical content.

The word "kritike" is Greek from the verb "krinein," which means to discern. Hence, kritike means the art of discerning or the art of critical analysis. Any form of philosophizing is, in one way or another, a "critique" of something. Being critical, therefore, is an attitude common to all philosophical traditions. Indeed, the meaning of philosophy is critique and to be philosophical is to be critical.

KRITIKE supports the Open Access Movement and is classified under the "Platinum OA" category, which means that articles published by the journal are fully accessible online without a subscription fee. Moreover, the journal does not levy charges against the authors for the publication of their works. Articles can either be read on site or downloaded as pdf files and old issues are archived for future retrieval.

KRITIKE is committed to meet the highest ethical standards in research and academic publication. The journal is guided by the principles set in its Publication Ethics and Publication Malpractice Statement.

KRITIKE is a Philippine Commission on Higher Education (CHED) Journal Incentive Program Recognized Journal (Journal Challenge Category) and is indexed and listed in the following:

The Philosopher's Index

Web of Science ${ }^{\mathrm{TM}}$ Core Collection (ISI)

Scopus ${ }^{\circledR}$ (Elsevier)

Humanities International Complete ${ }^{\mathrm{TM}}$ (EBSCO)

Humanities International Index ${ }^{\mathrm{TM}}$ (EBSCO)

ASEAN Citation Index

International Directory of Philosophy

Modern Language Association (MLA) Directory of Periodicals

Directory of Open Access Journals

PhilPapers: Philosophical Research Online

Google Scholar

KRITIKE is a biannual journal published in June and December of each year. 


\section{Editorial Board}

\section{Editors-in-Chief}

Paolo A. Bolaños, University of Santo Tomas

Roland Theuas DS. Pada, University of Santo Tomas

\section{Managing Editors}

Ranier Carlo V. Abengaña, University of Santo Tomas Jovito V. Cariño, University of Santo Tomas

Raniel SM. Reyes, University of Santo Tomas

\section{Associate Editors}

Fleurdeliz R. Altez-Albela, University of Santo Tomas

Moses Aaron T. Angeles, San Beda College

Marella Ada M. Bolaños, University of Santo Tomas Brian Lightbody, Brock University

Peter Emmanuel A. Mara, University of Santo Tomas

Melanie P. Mejia, University of Santo Tomas

Dean Edward A. Mejos, University of Asia \& the Pacific Mario Wenning, University of Macau

\section{Editorial Collaborative}

Agustin Martin Rodriguez, Ateneo de Manila University

Napoleon Mabaquiao, De La Salle University Jeffry Ocay, Silliman University

Renante Pilapil, Ateneo de Davao University Ryan Urbano, University of San Carlos

\section{Book Review Editors}

Darlene Demandante, University of Santo Tomas Tracy Ann P. Llanera, Macquarie University Wendyl Luna, University of New South Wales Jonathan Villacorta, University of Santo Tomas

\section{Style and Copy Editors}

Gian Carla D. Agbisit, University of Santo Tomas Julia D. De Castro, University of Santo Tomas

Pia Patricia P. Tenedero, University of Santo Tomas

\section{International Advisory Board}

Romualdo E. Abulad, University of Santo Tomas Karin Bauer, McGill University

Roger Burggraeve, Katholieke Universiteit Leuven

Alfredo P. Co, University of Santo Tomas

William Franke, Vanderbilt University

Leovino Ma. Garcia, Ateneo de Manila University Heinrich Geiger, Katholischer Akademischer Ausländer-Dienst Morny M. Joy, University of Calgary

John F. X. Knasas, University of St. Thomas - Houston

Megan Jane Laverty, Columbia University

Zosimo E. Lee, University of the Philippines - Diliman

Julius D. Mendoza, University of the Philippines - Baguio

Hans-Georg Moeller, University of Macau

Paul Patton, University of New South Wales

Karl-Heinz Pohl, Universität Trier

Peter L P Simpson, City University of New York

Nicholas H. Smith, Macquarie University John Rundell, University of Melbourne

Vincent Shen, University of Toronto John Weckert, Charles Sturt University 


\section{K R I T I K E}

\section{An Online Journal of Philosophy}

Volume 12, Number 2

December 2018

\section{FEATURED ESSAYS}

1 PAUL R. PATTON

The Reception and Evolution of Foucault's Political Philosophy

MARK W. WESTMORELAND

Césaire’s Revolution of Pedagogy

\section{ON FILIPINO PHILOSOPHY}

37 TOMAS G. ROSARIO $†$

Sundays with Roque: A Tale of Friendship and Companionship

48 MARC OLIVER D. PASCO

Ferriols at Heidegger: Ang Pagbigkas sa Kasaysayan bilang Talagang Nangyayari

65 NOEL L. CLEMENTE

Ilang Katagang Filipino bilang Bukal ng Pamimilosopiya

\section{ARTiCLes}

81 F.P.A. DEMETERIO III AND ROLAND THEUAS DS. PADA

A Humboldtian Critique of the University of the Philippines as the Flagship of Philippine Higher Education

JOSEPH MARTIN M. JOSE AND NAPOLEON M. MABAQUIAO, JR.

Resolving the Gettier Problem in the Smith Case: The Donnellan Linguistic Approach

DONGHYUN KIM

The Reinterpretation of Tetsurô Watsuji’s Communitarian Thought

Narrowing the Gap between Theory and Practice: Community of Inquiry and Its State in the Philippines

\section{BOOK REVIEW}

MacIntyre, Alasdair, Ethics in the Conflicts of Modernity: An Essay on Desire, Practical Reasoning and Narrative. 
Featured Essay

\title{
The Reception and Evolution of Foucault's Political Philosophy
}

Paul R. Patton

\begin{abstract}
With the benefit of the complete publication of Foucault's lectures at the Collège de France, the reception of his work by political philosophers in the English-speaking world during the late 1970s and early 1980s appears extremely confused. This reception was based on the English translations of work published in the mid-1970s, chiefly Discipline and Punish and The History of Sexuality Volume One, along with collections of interviews from the same period. The misunderstandings of those works were compounded by ignorance of developments in his approach to politics and his understanding of power worked out in lectures from 1976 to 1979. The aim of this paper is not simply to defend Foucault against critics from that period, but to show how a more complete understanding of the evolution of his political thought might enable a better understanding of the similarities and differences between his genealogical approach to power and government and the concerns of normative political philosophy.
\end{abstract}

Keywords: Foucault, power, government, political philosophy

$\mathrm{I}$

n 1971, amidst the social turmoil of post-1968 France, Michel Foucault founded an organization called the Prisons Information Group and published a long interview with Gilles Deleuze entitled "Intellectuals and Power." 1 This interview presented his work as that of someone driven by a desire to find new ways for intellectuals to contribute to struggles against oppression. The book that grew out of this activity, Discipline and Punish, was widely read as a political text about punishment, power and associated forms

${ }^{1}$ Michel Foucault and Gilles Deleuze, "Intellectuals and Power" in Michel Foucault, Language, Counter-Memory, Practice: Selected Essays and Interviews, ed. by Donald F. Bouchard, trans. by Donald F. Bouchard and Sherry Simon, (Ithaca, NY.: Cornell University Press, 1977); Gilles Deleuze, Desert Islands and Other Texts 1953-1974, ed. by David Lapoujade, trans. by Michael Taormina. (New York: Semiotext(e), 2004).

(c) 2018 Paul R. Patton

https://www.kritike.org/journal/issue 23/patton december2018.pdf

ISSN 1908-7330

(cc) $\mathrm{BY}-\mathrm{NC}-\mathrm{ND}$ 


\section{FOUCAULT'S POLITICAL PHILOSOPHY}

of knowledge. ${ }^{2}$ However, it has always had a somewhat strained relationship to the discipline of political philosophy, especially in the English- speaking world. Coincidentally, the book that has been widely credited with reviving the field of political philosophy from the doldrums of ordinary language philosophy and conceptual analysis, John Rawls's A Theory of Justice, was also published in $1971 .{ }^{3}$ For many critics of Foucault, the difference between these two books was perceived as that between political philosophy and something else, a confused historical or sociological approach to penal policy, the politics of prisons and the nature of discipline as a specific technology of power. In contrast, my aim is to see whether it is possible to regard both Foucault's work and that of Rawls as contributions to political philosophy; that is, as different but no less legitimate philosophical approaches to politics in the twentieth century. I argue that this requires a more comprehensive and nuanced appreciation of the evolution of Foucault's political philosophy after 1976.

\section{Responses}

Initial receptions of Foucault's work were not promising. Political philosophers tended to see his work as fatally flawed, confused or, in Habermas' critique, a renewed form of anti-modernist and anti-intellectual conservatism. ${ }^{4}$ Michael Walzer's response was in some ways more sympathetic-he saw Foucault as a fellow leftist-but, in other ways, no less critical. He drew attention to the absence of normative standards in Foucault's work in a manner that echoed similar claims made by Nancy Fraser and later repeated by Habermas, Charles Taylor and others. He characterized Foucault as a nihilist who endorsed no values that might provide grounds for moral or political evaluation. As such, Walzer argued,

\footnotetext{
2 See Michel Foucault, Surveiller et punir: Naissance de la prison (Paris: Gallimard, 1975). For the English translation, see Michel Foucault, Discipline and Punish, trans. by Alan Sheridan, (London: Allen Lane/Penguin, 1977).

${ }^{3}$ John Rawls, A Theory of Justice, (Cambridge, MA.: Harvard University Press, 1971).

${ }_{4}^{4}$ See among other initial responses: J. Minson, "Strategies for Socialists? Foucault's Conceptions of Power," Economy and Society, 9:1 (1980), 1-43; Nancy Fraser, "Foucault on Modern Power: Empirical Insights and Normative Confusions," Praxis International, 3 (1981), 272-287; reprinted in Nancy Fraser, Unruly Practices, (Minneapolis, MN: University of Minnesota Press, 1989), 17-34; Mark Philp, "Foucault on Power: A Problem in Radical Translation?" Political Theory, 11:1 (1983), 29-52; Michael Walzer, "The Politics of Michel Foucault," Dissent, Fall (1983), 481-90; reprinted as Michael Walzer, "The Politics of Michel Foucault," in Foucault: A Critical Reader, ed. by David Couzens Hoy (Oxford: Basil Blackwell, 1986), 51-68 (references are to this edition); also reprinted in slightly revised form as Michael Walzer, "The Lonely Politics of Michel Foucault," in The Company of Critics (New York: Basic Books, 1988), 191-209; Charles Taylor, "Foucault on Freedom and Truth," Political Theory, 12:2 (1984), 152-183; also reprinted as Charles Taylor, "Foucault on Freedom and Truth," in Foucault: A Critical Reader, 69-102; Jürgen Habermas, The Philosophical Discourse of Modernity, trans. by Frederick G. Lawrence (Cambridge, MA: MIT Press, 1987).

(C) 2018 Paul R. Patton

https://www.kritike.org/journal/issue 23/patton december2018.pdf

ISSN 1908-7330
}

(c) BY-NC-ND 
Foucault gave us no reason to expect that new forms of power would be any better than old ones and, more importantly, failed to address the normative principles that underpin such judgments: "Nor for that matter, does he give us any way of knowing what 'better' might mean." 5

The centrality of the concept of power to Foucault's work during the early 1970s-not only in Discipline and Punish but also in The History of Sexuality Volume One, ${ }^{6}$ where he outlined a project the whole point of which, as he said in a 1977 interview, lay "in a re-elaboration of the theory of power" 7 -meant that he gave frequent summaries, theses and responses to questions from interviewers about the nature of power and how it should be studied: power was dispersed throughout the social body; it should be studied at the periphery, in its effect on bodies, from the ground up, and so on. ${ }^{8}$ Walzer took this to imply that

Citizenship and government alike have been superseded. And yet the whole point of modern political theory, since the absolutist state provided the ground on which it was constructed, has been to account for these two things. ${ }^{9}$

Walzer's conception of the "whole point" of modern political theory underpins his conclusion that, in the end, Foucault did not have a political theory, or, if we persist in calling his work political theory, then it suffers "catastrophic weakness" by virtue of the absence of any consideration of democratic citizenship or the liberal state. ${ }^{10}$

\section{Political Philosophy and Approaches to Power}

A first point to make about this kind of criticism is that, while representative of many responses from English-speaking political philosophers, Walzer relied on a view of the nature and history of political

\footnotetext{
${ }^{5}$ Walzer, "The Politics of Michel Foucault," 61.

${ }^{6}$ Michel Foucault, The History of Sexuality, Volume One: An Introduction, trans. by Robert Hurley, (New York: Pantheon, 1978).

${ }^{7}$ Michel Foucault, Power/Knowledge: Selected Interviews and Other Writings, 1972-1977, ed. by Colin Gordon, trans. by Colin Gordon, Leo Marshall, John Mepham, and Kate Soper (Hemel Hempstead: Harvester Wheatsheaf, 1980), 187.

${ }^{8}$ See Foucault, The History of Sexuality, Volume One, 94-97; Michel Foucault, "Society Must Be Defended": Lectures at the Collège de France 1975-1976, ed. by Mauro Bertani and Alessandro Fontana, trans. by David Macey, (New York: Picador, 2003), 29-34. Hereafter cited as Society Must Be Defended.

${ }^{9}$ Walzer, "The Politics of Michel Foucault," 53.

${ }^{10}$ Ibid., 67.
} 


\section{FOUCAULT'S POLITICAL PHILOSOPHY}

philosophy that Foucault acknowledged, but only in order to distinguish it from his own approach. He repeatedly contrasted his own approach to power with the 'juridico-political' theory that sought to explain the origin and legitimacy of sovereign power. Criticism of what he called the 'juridicodiscursive' conception of power was a persistent theme of his analyses during this period. By 'juridico-discursive' he meant a conception of political power that is focused on the figure of the sovereign, the Leviathan in Hobbes's work of that name, who was the legitimate ruler of the body politic and the source of all its laws.

In a 1976 lecture, Foucault offered several historical reasons why political philosophers should have been preoccupied with this form of power: first, the imposition of law played a crucial role in the establishment of absolute, secular authority in the European middle ages and second, in the sixteenth and seventeenth centuries, political struggles were fought in relation to the sources of law: "the theory of sovereignty became a weapon that was used both to restrict and to strengthen royal power."11 Finally, he noted that after the democratization of political authority in the course of the nineteenth and twentieth centuries, the legal and constitutional apparatus of sovereignty remained the institutional framework of political power in the West.

During the early 1970s, Foucault objected that this conceptual focus on the formation and legitimation of political authority was not adequate to account for other ways in which power came to be exercised in modern European societies. In Discipline and Punish, for example, he showed that over the same period, a new mechanism of power with different objects and objective was invented. This disciplinary mechanism of power is applied primarily to bodies and what they do, rather than to land and what it produces. It was a mechanism of power that made it possible to extract time and labor, rather than commodities and wealth, from bodies. It was a type of power that was exercised through constant surveillance, rather than in discontinuous fashion through chronologically defined systems of taxation and obligation. It was a type of power that presupposed a closely meshed grid of material coercions, rather than the physical existence of a sovereign. As such, it defined a new economy of power based upon the principle that there had to be an increase in the subjugated forces of bodies, and an increase in the force and efficacy of that which subjugated them. Foucault later suggested that this new mechanism of power was "absolutely incompatible with relations of sovereignty" as well as being "one of bourgeois society's

${ }^{11}$ Foucault, Society Must Be Defended, 34.

(C) 2018 Paul R. Patton

https://www.kritike.org/journal/issue 23/patton december2018.pdf

ISSN 1908-7330

(cc) BY-NC-ND 
great inventions. It was one of the basic tools for the establishment of industrial capitalism and the corresponding type of society." 12

Discipline and Punish traced the development of this disciplinary power and the adoption of its techniques in most of the key institutions of modern society: armies, factories, schools, hospitals, and eventually, prisons. The analysis of this kind of power relation, exercised over individual bodies and small groups of people, and involving the detailed ordering of movements, activities, and dispositions in space and time, called for a quite different 'micropolitical' understanding of power. However, contra Walzer, Foucault never argued that the juridico-political conception of sovereign power disappeared in favor of disciplinary techniques. Rather, Foucault argued that it persisted alongside disciplinary power, not merely as ideology, but as organizing principle for the juridical and political institutions of modern European societies:

From the nineteenth century until the present day, we have then in modern societies, on the one hand, a legislation, a discourse, and an organization of public right articulated around the principle of the sovereignty of the social body and the delegation of individual sovereignty to the State; and we also have a tight grid of disciplinary coercions that actually guarantees the cohesion of that social body. Now that grid cannot in any way be transcribed in right, even though the two necessarily go together. A right of sovereignty and a mechanics of discipline. It is, I think, between these two limits that power is exercised. ${ }^{13}$

Foucault's diagnosis of the continued existence and function of the theory of sovereignty from the end of the eighteenth century onwards provides a context for his reluctance to pursue the standard questions and approach of modern political philosophy. In defense of his focus on disciplinary power, he famously wrote in The History of Sexuality Volume One that "[in] political thought and analysis, we still have not cut off the head of the king." ${ }^{14}$ By this, he meant that thought about political power remained bound up with the perspective of the sovereign, focused on the supposed universal principles that justify the exercise of sovereign power and set limits to its legitimate exercise. In contrast, Foucault described his own approach as directed at other, non-sovereign mechanisms, and as descriptive rather than normative,

12 Ibid., 36.

${ }^{13}$ Ibid., 37.

${ }^{14}$ Foucault, The History of Sexuality, Volume One, 88-89. 
concerned not with why but with how power is exercised, by what mechanisms, and to what ends. ${ }^{15}$

This brief characterization of Foucault's differences with the 'juridico-discursive' conception of power suggests a response to those critics who castigate him for not providing a normative criteria: are not these critics reproducing the standpoint, the speaking position and the approach of the theory of sovereignty? They call for global principles that would underpin the law, justify, and at the same time, establish limits to the exercise of legitimate power. Walzer is explicit in his defense of the traditional standpoint of political theory. On his view, no political theory can ignore the sovereign state that "establishes the general framework within which all other disciplinary institutions operate." 16 It must provide an account of "the liberal state and the rule of law," which implies "a kind of knowledge political philosophy and philosophical jurisprudence - that regulates disciplinary arrangements across our society." 17 Foucault refuses to provide this kind of jurisprudential knowledge. The response of Walzer and other political philosophical critics amounts to criticizing Foucault from the standpoint of a 'sovereigntist' and normative approach to power from which Foucault explicitly sought to distance himself.

\section{The Evolution of Foucault's Analysis of Power}

A second point to make in response to Walzer's criticism is that it illustrates, in dramatic fashion, a weakness shared by much of the criticism of Foucault's work published in English in the early 1980s (and by many of the defenses of his approach), namely that it was founded on complete ignorance of his political philosophy after 1976. In particular, the lectures of 1977-1978 (Security, Territory, Population) and of 1978-1979 (The Birth of Biopolitics) played no role in these evaluations. This is not surprising since these lectures were not published in French until 2004, and then in English in 2007 and 2008. It is in these lectures that Foucault began to focus on the exercise of sovereign power as this was theorized from the sixteenth through the eighteenth and nineteenth century. As in his earlier work on discipline and 'micropower,' he remained focused on the descriptive analysis of power, but at the level of its exercise over populations. This involved different objects and different techniques but still focused on the question of 'how' power is exercised rather than why. Eventually these lectures came to concentrate on the distinguishing features of liberal government as it emerged in the course

\footnotetext{
${ }^{15}$ Michel Foucault, Power, vol. 3 of Essential Works of Foucault, 1954-1984, ed. by James D. Faubion, trans. by Robert Hurley and Others (New York: The New Press, 2000), 336-337.

${ }^{16}$ Walzer, "The Politics of Michel Foucault," 66.

${ }^{17}$ Ibid.

(C) 2018 Paul R. Patton

https://www.kritike.org/journal/issue 23/patton december2018.pdf

ISSN 1908-7330
}

(c) BY-NC-ND 
of the eighteenth century. This was a modality of government informed by the study of political economy and concerned to allow for the operation of a market economy.

Walzer's ignorance of these developments in Foucault's thought, long before the article published in Dissent in 1983, leads him to infer a theory of liberalism as "nothing more than discipline concealed." 18 Foucault's lectures in 1978 and 1979 develop a rather more sophisticated account of liberalism as a novel form of government that sought to accommodate the practice of government with the operation of a market economy. The significant changes in Foucault's conceptualization of power, along with his explicit attention to the forms of exercise of state power, provide a direct rebuttal to Walzer's claim that Foucault pays no attention to the state, in particular, the liberal state. He does address the nature of the modern democratic state and citizenship, although not in terms of the search for jurisprudential principles of just or legitimate government.

I do not propose to dwell on the reasons for Foucault's reexamination and critique of his earlier approach to power, but simply to draw attention to the opening lecture in 1976 that begins with the statement of an intellectual crisis. Foucault says that he has had enough and would like to bring to a close the "mere fragments of research" that he has pursued in preceding years and that have become very repetitive, "always falling into the same rut, the same themes, the same concepts." 19 He connects this intellectual crisis to "changes in the conjuncture" but does not spell out the nature of these changes. It is worth noting that 1975 and 1976 were the years in which the Marxist orthodoxy that had sustained radical political movements in France since the 1960s began to fall apart: Soviet dissidents, "new philosophers," but also a turn towards armed struggle on the part of some elements of the extreme left. ${ }^{20}$

Whatever the reasons for this crisis in his own political thought around this time, for the remainder of his 1975 - 1976 lecture course, Foucault embarks on a self-critical examination of the nature of power. There are several dimensions to this: First, he poses a diagnostic question about the nature of power in modern society. He asks: what are the distinguishing features of power in modern European societies? In these and in subsequent lectures between 1976 and 1979, he offers a number of responses to this question, suggesting that it is fundamentally a form of biopower, of pastoral power, that it is characterized by the deployment of mechanisms of security

${ }^{18}$ Ibid., 62.

${ }^{19}$ Foucault, Society Must Be Defended, 3.

${ }^{20}$ For a longer discussion of this re-examination and the reasons for it, see Paul Patton, "From Resistance to Government: Foucault's Lectures 1976-1979" in A Companion to Foucault, ed. by C. Falzon, T. O’Leary, J. Sawicki (Oxford: Blackwell, 2013), 172-188.

(c) 2018 Paul R. Patton

https://www.kritike.org/journal/issue 23/patton december2018.pdf

ISSN 1908-7330

(cc) BY-NC-ND 


\section{FOUCAULT'S POLITICAL PHILOSOPHY}

and, finally, a succession of different forms of liberal government. Second, he poses a conceptual question about the nature of political power: how it operates. This is the most directly self-critical dimension since Foucault questions the 'war-repression' schema in terms of which he had earlier conceptualized the operation of power:

I would like to try to see the extent to which the binary schema of war and struggle, of the clash between forces, can really be identified as the basis of civil society, as both the principle and motor of the exercise of political power. Are we really talking about war when we analyze the workings of power? Are the notions of 'tactics,' 'strategy, and 'relations of force' valid? To what extent are they valid? Is power quite simply a continuation of war by means other than weapons and battles? 21

Third, he undertakes a change of perspective that, in one respect, challenges the regicidal declaration cited above. He no longer insists on the importance of studying power from below or at the capillary extremes of its exercise in the social body, but instead returns to the exercise of power by the figures of sovereign authority that emerged in the seventeenth and eighteenth centuries. From 1978 onwards, he embarked on an ambitious study of the different ways in which power was exercised (or supposed to be exercised) at the level of society as a whole. In this manner, he outlined in his 1978 and 1979 lectures a history of some of the major forms of 'governmentality,' by which he meant not so much the actual exercise of state power but the manner in which it was theorized and written about. In short, he proposed to study "the rationalization of governmental practice in the exercise of political sovereignty." 22 It was this project that led him to focus on the emergence of liberal governmentality from the middle of the eighteenth century onwards, and then in his 1979 lectures, on the outlines of neoliberal governmentality as this emerged during the latter part of the twentieth century.

These dimensions of Foucault's reconsideration of political power are not unrelated. Consider the movement from 'war-repression' to government as models of the exercise of power. The 'micro-physics' of disciplinary power outlined in Discipline and Punish presupposed that power relations are grounded in relations of force and that "one should take as the model for

${ }^{21}$ Foucault, Society Must Be Defended, 18.

22 Michel Foucault, The Birth of Biopolitics: Lectures at the Collège de France 1978-1979, ed. by Michel Senellart, trans. by Graham Burchell (Houndmills, Basingstoke and New York: Palgrave Macmillan, 2008), 2.

(C) 2018 Paul R. Patton

https://www.kritike.org/journal/issue 23/patton december2018.pdf

ISSN 1908-7330

(cc) BY-NC-ND 
power relations a perpetual battle rather than a contract regulating a transaction or the conquest of a territory." ${ }^{23}$ The History of Sexuality, Volume One famously argued that "power must be understood in the first instance as the multiplicity of force relations immanent in the sphere in which they operate" and that the condition of possibility of all power relations must be sought in "the moving substrate of force relations which, by virtue of their inequality, constantly engender states of power." ${ }^{24}$ At the same time, this passage offered a more nuanced view of the usefulness of battle as the model for power relations, suggesting that the difference between war and politics was not a difference in kind but a difference of strategy whereby the force relations present in a given society could be played out either in the forms of war or politics. Foucault's discussion of power here draws a distinction, that is obscured in the English translation, between power in general, as it is exercised in local relations throughout society, and 'the power' understood as the overall system of domination and control: "power insofar as it is permanent, repetitive, inert and self-reproducing." ${ }^{25}$ Foucault's nominalist understanding of the latter relies on the military metaphor: "'the' power is not an institution, and not a structure; neither is it a certain strength with which some are endowed; it is the name that one attributes to a complex strategical situation in a particular society." 26

At the beginning of the 1976 lectures, "Society Must Be Defended," Foucault explicitly questioned the applicability of concepts such as antagonism, rivalry or confrontation, and struggle between contending parties to the analysis of power. Similarly, a number of comments in interviews recorded around this time allude to his doubts about the warrepression schema. For example, in the "Truth and Power" interview, which took place in June 1976, he commented that "it's astonishing to see how easily and self-evidently people talk of warlike relations of power or of class struggle without ever making it clear whether some form of war is meant, and if so what form." ${ }^{27}$ In "The Eye of Power" interview conducted around the same time, he commented on the frequency with which people use the term 'struggle' without questioning what is implied by this term: "Is the relation of forces in the order of politics a warlike one? I don't personally feel prepared to answer this with a definite yes or no." 28

\footnotetext{
${ }^{23}$ Foucault, Discipline and Punish, 26.

${ }^{24}$ Foucault, The History of Sexuality, Volume One, 92-93.

25 Ibid., 93.

${ }^{26}$ Ibid. (translation modified)

${ }^{27}$ Foucault, Power, 124.

${ }^{28}$ Michel Foucault, Jean-Pierre Barou, and Michelle Perrot, "The Eye of Power," in Power/Knowledge: Selected Interviews and Other Writings 1972-1977, 164.
} 
This dissatisfaction with the war-repression schema was only partly expressed in The History of Sexuality, Volume One published at the end of 1976. As noted above, the language of forces and strategies continued to provide the conceptual frame for the analysis of power. There was, however, a chapter devoted to criticizing the 'repressive hypothesis' in relation to sexuality. ${ }^{29}$ The reason Foucault continued to rely on the war model of the operation of power is that, at this point, he had not settled on any alternative. Instead of providing an alternative, the 1975-1976 lectures only repeat and reformulate the conceptual question:

To what extent can a relationship of domination boil down to or be reduced to the notion of a relationship of force? To what extent can the relationship of force be reduced to a relationship of war? ${ }^{30}$

\section{Power and Government}

The closest Foucault came to a definitive response to the conceptual questions posed in his 1976 lectures was in the essay, "The Subject and Power," published for the first time in English in Critical Inquiry in 1982, and as an appendix to Dreyfus and Rabinow's Beyond Structuralism and Hermeneutics. ${ }^{31}$ It is unclear precisely when this essay was written. Arnold Davidson suggests that "there is compelling internal evidence that parts of it were written several years earlier." 32 What is clear is that the key sections of the essay that provide a definition of power could only have been written after Foucault's discovery of the rich theme of government and governmentality in 1978.

Foucault begins by distinguishing power relations from relations of communication, and from the power exercised over things through the

\footnotetext{
29 Arnold Davidson's Introduction to "Society Must Be Defended" acknowledges Foucault's questioning of the war model of power in interviews, but then curiously disregards this critical dimension of the 1976 lectures by suggesting that "Foucault's preoccupation with the schema of war was central to this formulation of the strategic model of power, of force-relations, a strategic model that would allow us to reorient our conception of power" (Arnold I. Davidson, Introduction to Michel Foucault, Society Must Be Defended, xviii). In fact, Foucault's preoccupation with the schema of war was rather the beginnings of a shift in his thinking about power away from the strategic model.

${ }^{30}$ Foucault, Society Must Be Defended, 46.

${ }^{31}$ Michel Foucault, "The Subject and Power," in Critical Inquiry, 8:4 (1982), 777-795. Reprinted as Michel Foucault, "The Subject and Power," Afterword to H. Dreyfus and P. Rabinow, Michel Foucault: Beyond Structuralism and Hermeneutics (Chicago: The University of Chicago Press, 1982), 208-226. Also reprinted in Foucault, Power, 326-348.

32 Arnold Davidson, "In Praise of Counter-Conduct," History of the Human Sciences, 24:4 (2011), 39, note 4 .

(C) 2018 Paul R. Patton

https://www.kritike.org/journal/issue 23/patton december2018.pdf

ISSN 1908-7330
}

(cc) BY-NC-ND 
exercise of particular physical, technical or organizational capacities. All of these may be involved in a given social institution or activity, but the specificity of power relations is that they involve action upon the actions of others:

In effect, what defines a relationship of power is that it is a mode of action that does not act directly and immediately on others. Instead, it acts upon their actions: an action upon an action, on possible or actual future or present actions. ${ }^{33}$

This understanding of power relations is significantly different from Foucault's earlier conception of power relations as conflict or struggle between opposing forces. The most important difference is the fact that the parties to relations of power are now conceived as agents endowed with a degree of freedom. The exercise of power presupposes that those on whom power is exercised are subjects capable of action, and that they are, in fact, free to act in a number of ways: "Power is exercised only over free subjects, and only insofar as they are 'free'." 34 The scare quotes around 'free' here indicate that this is not a natural freedom but rather specific kinds of freedom that are required for certain kinds of government, or for the government of certain kinds of subjects.

The definition of power as action upon the actions of others confirms Foucault's rupture with the war model and the juridical conception of power. Power is not something possessed that can be exchanged or transferred. It does not essentially involve either contracts or violence, which does not mean that the exercise of power cannot, in particular cases, involve the obtaining of consent or the threat of violence. Nor does it essentially involve struggle between contending forces. Rather, power acts on the 'field of possibilities' that circumscribes the actions of others. It is a way of directing or governing the actions of others:

Basically, power is less a confrontation between two adversaries or their mutual engagement than a question of 'government'... The relationship proper to power would therefore be sought not on the side of violence or of struggle, nor on that of voluntary contracts (all of which can, at best, only be the instruments of power)

\footnotetext{
${ }^{33}$ Foucault, Power, 340.

${ }^{34}$ Ibid., 342.
} 
but, rather, in the area of that singular mode of action, neither warlike nor juridical, which is government. ${ }^{35}$

So how did Foucault get from power as the effect of conflicting forces to power as government? The breakthrough in his conceptual analysis of power occurred two years after those questions were first raised, in his 1977-1978 lectures Security, Territory, Population. ${ }^{36}$ It was here that he began to analyze the technologies of state power that he called mechanisms of security. These do not involve direct confrontation between contending forces, but are forms of action on a population, where this is considered as a natural phenomenon subject to various kinds of regular behavior: economic, demographic, epidemiological, and so on. These mechanisms of security, and the forms of knowledge associated with them represented a shift from a political order characterized by the exercise and maintenance of sovereignty to one characterized by government. From this point onwards, Foucault's analyses of the exercise of power became focused on government rather than war.

The theme of government is explicitly introduced in the fourth lecture in 1978. However, an earlier lecture devoted to the study of 'mechanisms of security' introduced the basic elements of the new form of governmental power that emerged in Europe in the course of the eighteenth century. Foucault's lecture on 18 January 1978 was devoted to proposals put forward in the middle of the eighteenth century to deal with the problem of grain shortage. La disette (meaning 'dearth,' or 'scarcity') was defined as "the present insufficiency of the amount of grain necessary for a nation's subsistence." 37 Grain shortage was a threat to governments because it could quickly lead to revolt on the part of urban populations deprived of food. Previously, it had been dealt with by regulations intended to prevent such shortages from occurring:

price control, and especially control of the right to store; the prohibition of hoarding with the consequent necessity of immediate sale; limits on export, the prohibition of sending grain abroad with, as the simple restriction on this, the limitation of the extent of land under cultivation, because if the cultivation of grains is

\footnotetext{
${ }^{35}$ Ibid., 341.

${ }^{36}$ Michel Foucault, Security, Territory, Population: Lectures at the Collège de France 19771978, ed. by Michel Senellart, trans. by Graham Burchell. (Houndmills, Basingstoke and New York: Palgrave Macmillan, 2007).

37 “La disette, c'est-à-dire l'insuffisance actuelle de la quantité des grains nécessaire pour faire subsister une Nation," Louis-Paul Abeille, Lettre d'un négociant sur la nature du commerce des grains (1763) (Paris: Institut Coppet, 2014), 13. As quoted in Foucault, Security, Territory, Population, 30.

(C) 2018 Paul R. Patton https://www.kritike.org/journal/issue 23/patton december2018.pdf ISSN 1908-7330
}

(c) BY-NC-ND 
too extensive, the surplus from this abundance will result in a collapse of prices, so that the peasants will not break even. ${ }^{38}$

At the end of the seventeenth century, some economic advisors to the French monarchy argued that the free circulation of grain along the lines of the English model was a better mechanism to ensure food security. This was a key proposition defended by Physiocrats, such as Quesnay, who became influential in French economic policy in the 1750s. Foucault examines the defense outlined by Louis-Paul Abeille in the 1763 text, Letter from a trader on the nature of the grain trade. Abeille was involved in French economic policy during the 1760 s when he served as Secretary to the Bureau of Commerce. Foucault proposes to consider this indicative text "from the perspective of a genealogy of technologies of power." ${ }^{39}$ Edicts in 1763 and 1764 resulted to a radically new policy for dealing with the problem of grain shortage that amounted to

a complete change, or rather a phase in a major change in the techniques of government and an element in the deployment of what I will call apparatuses of security. In other words, you could read the principle of the free circulation of grain as the consequence of a theoretical field and also as an episode in the mutation of technologies of power and an episode in the installment of this technique of apparatuses of security that seems to me to be one of the typical features of modern societies. ${ }^{40}$

The new policy sought to take into account, not just the market price of grain, but the whole economic cycle of production and circulation that produced more or less grain. Rather than artificially set a low price, it sought to allow for, and even favor, a higher price, so that more investment would be made in production. It recommended the removal of restrictions on hoarding, on the export and import of grain, and on the extent of land devoted to its production in order to rely on market mechanisms to stabilize the price and the supply of grain. It involved a conception of market mechanisms that was "not just the analysis of what happens. It is at once an analysis of what happens and a program for what should happen." ${ }^{11}$ In order to develop this program, Foucault pointed out, the analysis of the production of grain had to

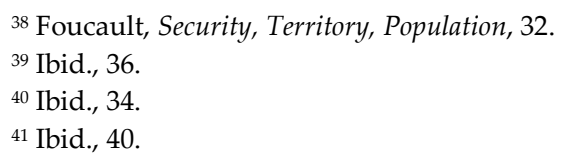




\section{FOUCAULT'S POLITICAL PHILOSOPHY}

be broadened in several respects: First, on the side of production, it had to consider the entire cycle from the initial actions of producers up to the final profit. Second, on the side of the market, the analysis had to consider not just the domestic market but all of the international sources of grain. Third, the analysis had to be broadened on the side of the protagonists in order to understand

how and why they act, what calculation they make when, faced with a price rise, they hold back grain, and what calculation they make when, on the other hand, they know there is freedom, when they do not know how much grain will arrive, when they hesitate so as to know whether there will be a rise or fall in the amount of grain. All of this, that is to say that completely concrete element of the behavior of homo oeconomicus, must also be taken into account ... ${ }^{42}$

The new measures aimed at the security of food for the population at large, but they worked through the decisions of individual producers, merchants, and consumers by allowing the free circulation of goods. They did not involve the direct confrontation and struggle of contending forces, as suggested by the schema of war. Nor did they involve direct action upon the forces of individuals and groups in the manner of disciplinary techniques. Rather, they established conditions under which market incentives would cause individuals to act in ways that would address the problem of shortage. In this manner, the new measures act indirectly on the actions of others. They do not seek to directly regulate the production and circulation of grain, but rather, to achieve the desired result by allowing the natural mechanisms of the economic cycle to operate. Foucault notes that this manner of exercising power

is profoundly linked to the general principle of what is called liberalism. The game of liberalism-not interfering, allowing free movement, letting things follow their course; laisser faire, passer et aller-basically and fundamentally means acting so that reality develops, goes its way, and follows its own course according to the laws, principles, and mechanisms of reality itself. ${ }^{43}$

\footnotetext{
42 Ibid., 41.
}

${ }^{43}$ Ibid., 48. 
Foucault returns to this problem of grain scarcity and the different ways of dealing with it in his final lecture in 1978, suggesting, with characteristic hyperbole, that he has done little more over the course of these lectures than comment on the texts dealing with this issue. The intervening lectures devoted to 'police' government allow him to situate the debates over grain scarcity in the broader context of criticism of this style of government. He rehearses key theses of the criticism of the mercantilist inspired policy of police in relation to grain production, and suggests that the market solution to the problem of grain shortage embodies a new rationality of government, one that no longer supposes that government regulation can ensure the being and well-being of people. This new rationality also involves a new conception of the subjects of government that further specifies their nature as 'free' agents. They are subjects supposed to have certain irreducible interests, and supposed to be able to calculate optimal ways of satisfying those interests. In effect, this form of government is exercised neither over subjects of power or force-as the analysis of disciplinary power supposed-nor over juridical subjects of right, but over subjects of interest. This is the government of homo oeconomicus. Henceforth:

The state is envisioned as the regulator of interests and no longer as the transcendent and synthetic principle of the transformation of the happiness of each into the happiness of all. I think this is a crucial change that brings us face to face with an essential element of the history of the eighteenth, nineteenth, and also twentieth century, that is to say: What should the state's game be, what role should it play, what function should it perform in relation to that fundamental and natural game of private interests? ${ }^{44}$

In this manner, Foucault suggests, by virtue of its reliance on the individual governed as a subject of interest, and by virtue of its mode of acting indirectly on the actions of the governed, "the governmentality of the eighteenth century économistes introduces some of the fundamental lines of modern and contemporary governmentality." 45

${ }^{44}$ Ibid., 346-347.

${ }^{45}$ Ibid., 348. 


\section{The Relationship between the Conceptual and the Diagnostic Questions}

There is more to say about Foucault's analysis of liberal governmentality and its relation to the concerns of normative political philosophy, but it is worthwhile to return for a moment to the different dimensions of his reconsideration of power from 1976 onwards, in order to see how these were related to one another. Foucault's answer to the conceptual question was a direct consequence of the shift of focus from micropower to power exercised by the state over entire populations, and of the answer that he eventually gave to the diagnostic question, namely that the exercise of state power in the West, from the latter half of the eighteenth century onwards, was predominantly liberal.

Foucault's 1979 lectures point to some of the fundamental features of the liberal art of government: (1) the transformation of the relation between government and economy involved in the shift from market as a site of jurisdiction to the market as a site of veridiction: "The market must tell the truth (dire le vrai); it must tell the truth in relation to governmental practice," 46 (2) the idea that government should promote the welfare and well-being of individuals. The concept that connects the idea of the market as site of veridiction and the idea of (public) utility is the concept of interest:

Governmental reason in its modern form, in the form established at the beginning of the eighteenth century ... is a reason that functions in terms of interest ... [this involves] a complex interplay between individual and collective interests, between social utility and economic profit, between the equilibrium of the market and the regime of public authorities, between basic rights and the independence of the governed. ${ }^{47}$

Note the correspondence of this characterization modern governmentality with the characterization of power as action on the actions of others that Foucault gave in 'Subject and Power.' This is a manner of exercising power that acts indirectly. Government, he says,

no longer has a direct hold on things and people; it can only exert a hold, it is only legitimate, founded in law and reason, to intervene, insofar as interest, or interests,

${ }^{46}$ Foucault, The Birth of Biopolitics, 32.

${ }^{47}$ Ibid., 44.

(C) 2018 Paul R. Patton

https://www.kritike.org/journal/issue 23/patton december2018.pdf

ISSN 1908-7330

(c) BY-NC-ND 
the interplay of interests, make a particular individual, thing, good, wealth, or process of interest for individuals. ${ }^{48}$

The definition of power as action on the action of others corresponding to the liberal mode of exercise of power points to another feature of Foucault's approach to the analysis of power that was often overlooked by his English language critics, namely its resolute historicism. 'The Subject and Power' reiterates his insistence, in The History of Sexuality, Volume One and elsewhere, that the analysis of power relations and the forms of its exercise requires not so much a theory of power as an 'analytics' that, as he says, would provide the concepts required for the analysis of particular modalities of power. ${ }^{49}$ The bare object of study, namely power, does not provide a sufficient basis for an adequate conceptualization: "We have to know the historical conditions that motivate our conceptualization. We need a historical awareness of our present circumstances." 50 In particular, Foucault adds, we need to check "the type of reality with which we are dealing," which means the type of power that operates in our present circumstances. In other words, there is a direct relationship between answers to the diagnostic and the conceptual questions about power.

In this sense, Foucault's approach to the analysis of power is thoroughly historicist. He is not interested in a conceptual analysis of power in general, or in the abstract, but rather, in a conceptual analysis that responds to the present, to the particular form or forms of power by means of which we are now governed. In 'The Subject and Power,' he suggests that this is a form of power that 'individualizes' or that makes people subjects of certain kinds. The eighteenth century saw the introduction of a new organization of the pastoral power that had previously developed in the context of the Church's responsibility for the salvation of souls, one in which the material, rather than the spiritual, well-being of individuals became the concern of government. In this way, he suggested that "we can see the state as a modern matrix of individualization or a new form of pastoral power." 51 Making individuals into certain kinds of subjects, or treating them as certain kinds of subjects, is a way of acting on their actions. In these terms, we can read the second part of this text entitled 'How is Power Exercised?' as setting out the conceptual requirements for the study of this modern, individualizing form of governmental power.

${ }^{48}$ Ibid., 45.

${ }^{49}$ Foucault, The History of Sexuality, Volume One, 82.

${ }^{50}$ Foucault, Power, 327.

${ }^{51}$ Ibid., 354.

(c) 2018 Paul R. Patton

https://www.kritike.org/journal/issue 23/patton december2018.pdf

ISSN 1908-7330

(cc) BY-NC-ND 


\section{Conclusion}

Let me try to draw together the main threads of this overview of developments in Foucault's political philosophy as outlined in lectures after 1976, and comment on what it tells us about Foucault's relation to normative political philosophy. First, his discovery of governmentality is a development of his earlier descriptive analysis of power, albeit one that is increasingly directed at the state and its manner of governing populations and the conditions of their life, well-being and prosperity. As a consequence, the criticism of Walzer and others that Foucault ignores the state is redundant.

Second, his analysis of governmentality becomes increasingly focused on the liberal mode of government that emerged in Europe from eighteenth century onwards. Foucault's 1978-79 lectures, then, discuss elements of the neoliberal governmentality that emerged towards the middle of the twentieth century, first in Germany, and then in United States. One reviewer suggests that these lectures represent Foucault's one and only 'diversion into contemporary political philosophy', so long as we understand that his interest does not involve the juridical tradition of contractarian and natural rights philosophy associated with Rawls and Nozick but rather the political economic tradition: "Think of the tradition that goes from Hobbes, Hume and Adam Smith to Milton Friedman, Friedrich Hayek, David Gauthier, and contemporary evolutionary game theory." 52 To the extent that neoliberal conceptions of the proper business of government came to inform specific policy proposals, they became part of the public political reason. In this sense, Foucault's outline of a genealogy of modern governmentality may be read as a contribution to an historical conception of public reason. ${ }^{53}$

Thirdly, the analysis of governmentalities involves a historical approach to contemporary forms of the exercise of state power that seeks neither to justify nor to set limits to legitimate power-it is not explicitly normative in the way that much liberal political philosophy is-but it does, nevertheless, develop a historical perspective on the kinds of normativity that concern political philosophers. For example, the 1979 lectures misleadingly titled The Birth of Biopolitics, describe a fundamental duality at the heart of the modern exercise of state power that is also reflected in normative political theory, namely, the sense in which it refers to two quite different subjects of government: homo oeconomicus as opposed to homo juridicus. They point to the

52 F. Guala, “Critical Notice of Michel Foucault," Economics and Philosophy, 22 (2006), 429, 431. See also, Michel Foucault, Naissance de la biopolitique: Cours au Collège de France, 1978-1979 (Seuil/ Gallimard, 2004).

53 For a detailed discussion of this claim, see Paul Patton, "Foucault and Rawls: Government and Public Reason" in The Government of Life: Foucault, Biopolitics, and Neoliberalism, ed. by Vanessa Lemm and Miguel Vatter (New York: Fordham University Press, 2014), 141-162.

(C) 2018 Paul R. Patton

https://www.kritike.org/journal/issue 23/patton december2018.pdf

ISSN 1908-7330

$(c c))$ BY-NC-ND 
emergence of a modern, bipolar political normativity that resulted in "two ways of constituting the regulation of public authorities by law, two conceptions of law, and two conceptions of freedom." 54 The thought of normative political philosophers, such as Rawls, is shaped by this duality, even though it is not an explicit topic for most of them. Consider the manner in which Rawls's theory of justice combines the economic and juridical subjects of government. Unlike earlier contractarians such as Locke, Rawls does not begin with individuals endowed with rights by God or nature. Rather, he begins from a conception of a rational person with a capacity to form a conception of the good and a life plan "designed to permit the harmonious satisfaction of his interests." 55 Rawls relies on an ideal or hypothetical form of original contract in which parties would decide on principles of justice behind a veil of ignorance that deprived them of all but the most basic knowledge about the kind of society in which they would live. The first principle that would be accepted under such conditions states that each person is to have an equal right to the most extensive basic liberty compatible with a similar liberty for others. This principle establishes the basic rights associated with the juridical subject of earlier liberalisms. However, the subjects of the original position supposed to endorse this principle are subjects of interest. He draws an explicit analogy between the situation of choice in the original position and the situation in competitive markets, where price equilibrium is attained on the basis of exchanges among individuals seeking to advance their own interests. In Rawls's words, the principles of justice are those that "rational persons concerned to advance their interests would accept." 56

Finally, I am not suggesting that the lectures from 1976 to 1979 present the 'real' political thought of Foucault that Walzer and many other critics and commentators ignored, for good reason since it was unavailable to them. Rather, my point is that a more fruitful treatment of Foucault as a political philosopher needs to take into account the whole body of work on power and government produced in the 1970s and 1980s. An informed appreciation of Foucault as a political philosopher has yet to occur. I hope I have provided some indication of what this might entail and how it might be carried out.

School of Language and Humanities, Faculty of Arts E Social Sciences, University of New South Wales, Australia

${ }^{54}$ Foucault, The Birth of Biopolitics, 42.

${ }^{55}$ Rawls, A Theory of Justice, 93.

${ }^{56}$ Ibid., 118.

(c) 2018 Paul R. Patton

https://www.kritike.org/journal/issue 23/patton december2018.pdf

ISSN 1908-7330

(cc) BY-NC-ND 


\section{References}

Abeille, Louis-Paul, Lettre d'un négociant sur la nature du commerce des grains (Paris: Institut Coppet, 2014).

Davidson, Arnold I., "In Praise of Counter-Conduct," History of the Human Sciences, 24:4 (2011).

Introduction to Michel Foucault, "Society Must Be Defended": Lectures at the Collège de France 1975-1976, ed. by Mauro Bertani and Alessandro Fontana, trans. by David Macey, (New York: Picador, 2003).

Deleuze, Gilles, Desert Islands and Other Texts 1953-1974, ed. by David Lapoujade, trans. by Michael Taormina. (New York: Semiotext(e), 2004).

Foucault, Michel, Discipline and Punish, trans. by Alan Sheridan, (London: Allen Lane/Penguin, 1977).

Naissance de la biopolitique: Cours au Collège de France, 1978-1979 (Seuil/ Gallimard, 2004).

Power, vol. 3 of Essential Works of Foucault, 1954-1984, ed. by James D. Faubion, trans. by Robert Hurley and Others (New York: The New Press, 2000).

Power/Knowledge: Selected Interviews and Other Writings, 19721977, ed. by Colin Gordon, trans. by Colin Gordon, Leo Marshall, John Mepham, and Kate Soper (Hemel Hempstead: Harvester Wheatsheaf, 1980).

Security, Territory, Population: Lectures at the Collège de France 1977-

1978, ed. by Michel Senellart, trans. by Graham Burchell. (Houndmills, Basingstoke and New York: Palgrave Macmillan, 2007).

"Society Must Be Defended": Lectures at the Collège de France 1975-

1976, ed. by Mauro Bertani and Alessandro Fontana, trans. by David Macey, (New York: Picador, 2003).

Surveiller et punir: Naissance de la prison (Paris: Gallimard, 1975). The Birth of Biopolitics: Lectures at the Collège de France 1978-1979, ed. by Michel Senellart, trans. by Graham Burchell (Houndmills, Basingstoke and New York: Palgrave Macmillan, 2008).

The History of Sexuality, Volume One: An Introduction, trans. by Robert Hurley, (New York: Pantheon, 1978).

"The Subject and Power," Afterword to H. Dreyfus and P.

Rabinow, Michel Foucault: Beyond Structuralism and Hermeneutics

(Chicago: The University of Chicago Press, 1982).

, "The Subject and Power," in Critical Inquiry, 8:4 (1982).

(C) 2018 Paul R. Patton

https://www.kritike.org/journal/issue 23/patton december2018.pdf

ISSN 1908-7330

(c) ) BY-NC-ND 
Foucault, Michel and Gilles Deleuze, "Intellectuals and Power" in Michel Foucault, Language, Counter-Memory, Practice: Selected Essays and Interviews, ed. by Donald F. Bouchard, trans. by Donald F. Bouchard and Sherry Simon, (Ithaca, NY.: Cornell University Press, 1977).

Foucault, Jean-Pierre Barou, and Michelle Perrot, "The Eye of Power," in Power/Knowledge: Selected Interviews and Other Writings, 1972-1977, ed. by Colin Gordon, trans. by Colin Gordon, Leo Marshall, John Mepham, and Kate Soper (Hemel Hempstead: Harvester Wheatsheaf, 1980).

Fraser, Nancy. "Foucault on Modern Power: Empirical Insights and Normative Confusions," Praxis International, 3 (1981). Unruly Practices, (Minneapolis, MN: University of Minnesota Press, 1989).

Guala, F., "Critical Notice of Michel Foucault," Economics and Philosophy, 22 (2006).

Habermas, Jürgen, The Philosophical Discourse of Modernity, trans. by Frederick G. Lawrence (Cambridge, MA: MIT Press, 1987).

Minson, J., "Strategies for Socialists? Foucault's Conceptions of Power," Economy and Society, 9:1 (1980).

Patton, Paul, "Foucault and Rawls: Government and Public Reason" in The Government of Life: Foucault, Biopolitics, and Neoliberalism, ed. by Vanessa Lemm and Miguel Vatter (New York: Fordham University Press, 2014).

"From Resistance to Government: Foucault's Lectures 19761979" in A Companion to Foucault, ed. by C. Falzon, T. O'Leary, J. Sawicki (Oxford: Blackwell, 2013).

Philp, Mark, "Foucault on Power: A Problem in Radical Translation?" Political Theory, 11:1 (1983).

Rawls, John, A Theory of Justice, (Cambridge, MA.: Harvard University Press, 1971).

Taylor, Charles, Foucault on Freedom and Truth," in Foucault: A Critical Reader, ed. by David Couzens Hoy (Oxford: Basil Blackwell, 1986). "Foucault on Freedom and Truth," Political Theory, 12:2 (1984).

Walzer, Michael, "The Lonely Politics of Michel Foucault," in The Company of Critics (New York: Basic Books, 1988).

"The Politics of Michel Foucault," Dissent, Fall (1983).

"The Politics of Michel Foucault," in Foucault: A Critical Reader, ed. by David Couzens Hoy (Oxford: Basil Blackwell, 1986). 
Featured Essay

\title{
Césaire's Revolution of Pedagogy
}

\section{Mark W. Westmoreland}

\begin{abstract}
Just as Césaire called for revolutionary practices that would put an end to colonization, its corrupt institutions, and its dehumanizing policies, his words still speak truth to a world marred by neocolonialism and rampant inequalities. His call for revolution continues to challenge us to create "a humanism made to the measure of the world." In this essay, I turn to his Discourse on Colonialism and suggest that his critique can still be useful for the twenty-first century. First, I provide an account of Césaire's diagnosis of the brutality of colonialism. Second, I consider the role of public intellectual. I argue that the self-determination of colonized peoples, dialogue, and radical change of institutions are necessary ingredients for forming a nonmanichaean humanity.
\end{abstract}

Keywords: Césaire, pedagogy, revolution, intellectuals

17 et the peoples speak. Let the black peoples come onto the great stage of history." 1 These words were spoken by Aimé Césaire at 1956 Congress of Black Writers and Artists in Paris. His words raise questions about who speaks, with what content does one speak, and how, or in what manner, one speaks. What will the colonized say? In "Black Orpheus," Jean-Paul Sartre writes, "When you removed the gag that was keeping these black mouths shut, what were you hoping for? That they would sing your praises? Did you think that when they raised themselves up again, you would read adoration in the eyes of these heads that our fathers had forced to bend down to the very ground? Here are black men standing, looking at us, and I hope that you-like me-will feel the shock of being seen." 2 The colonial white gaze attempts to trap black persons under the white gaze, which is both the lens and action through which whites viewexplicitly or implicitly-black persons. It filters that view so that the default way of seeing black persons is that they are ignorant or threatening. But Sartre

${ }^{1}$ Aimé Césaire, “Culture and Colonization," Social Text, 28:2 (2010), 142.

2 Jean-Paul Sartre, "Black Orpheus," in Race, ed. by Robert Bernasconi (Malden, MA: Blackwell, 2001), 115.

(C) 2018 Mark W. Westmoreland

https://www.kritike.org/journal/issue 23/westmoreland december2018.pdf

ISSN 1908-7330

(cc) BY-NC-ND 
has borne witness to the countergaze in which the insidious nature of whiteness is called out. A new world begins.

The fundamental question of the so-called postcolonial moment is about revolutionary practice, namely, what does it mean to begin? At the same time, an answer requires a new kind of pedagogy-one of destroying the world in order to lead into another. In his poem "The Thoroughbreds," Césaire writes:

\author{
As everything was dying, \\ I did, I did grow - as big as the world- \\ and my conscience wider than the sea! \\ Last sun. \\ I explode. I am the fire, I am the sea. \\ The world is dissolving but I am the world
}

The end, the end did we say. ${ }^{3}$

On this passage, John Drabinski comments that "the end of the world is what makes consciousness possible and makes consciousness wider than the seaperhaps exceeding, in its beginning again, the catastrophe represented by the sea, where the history and memory of Africa were drowned." 4 If the pedagogue's aim is to critique the present in order to create new horizons of the imaginary, then there exists a need to grasp the ever-present tension between past and future. Paulo Freire suggests that "the point of departure must always be with men and women in the 'here' and 'now,' which constitutes the situation within which they are submerged, from which they emerge, and in which they intervene." 5 In addition to the temporal dimension of the critique of the present, there is a spatial dimension which inclines one to begin with the situation of the marginalized, the oppressed, the wretched of the earth. There is no neutral standpoint since there is no individual or group that is not within a social world. Alice Walker writes, "I believe that the truth about any subject only comes when all sides of the story are put together, and all their different meanings make one new one." ${ }^{\prime}$ Each epistemic group contributes partial (not universal) knowledge, situated knowledge. To speak briefly, Patricia Hill Collins in Black Feminist Thought

\footnotetext{
3 Aimé Césaire, "The Thoroughbreds," in The Collected Poetry, trans. by Clayton Eshleman and Annette Smith (Berkeley, CA: University of California Press, 1983), 101.

4 John E. Drabinski, "Césaire's Apocalyptic Word," South Atlantic Quarterly, 115:3 (2016), 574

${ }^{5}$ Paulo Freire, Pedagogy of the Oppressed (New York: Continuum, 2007), 85.

${ }^{6}$ Alice Walker, In Search of Our Mother's Gardens (San Diego, CA: Harcourt Brace Jovanovich, 1983), 49.
}

(c) 2018 Mark W. Westmoreland https://www.kritike.org/journal/issue 23/westmoreland december2018.pdf ISSN 1908-7330 


\section{CÉSAIRE'S REVOLUTION OF PEDAGOGY}

offers one necessary but insufficient remedy to injustice: dialogue. Dialogue is not two monologues happening concurrently. Rather, it implies empathy and call-and-response. Dialogue implies a genuine attempt to understanding how, to borrow from Nikki Giovanni, "the universal comes from the particular." 7 Collins suggests that black feminist epistemology refuses the universalizing of positivism, which separates the knower from the thing known, eschews emotion, disavows values with regard to facts, and approaches knowledge through adversity. Collins also claims that advocating for situated knowledge is not the same as advocated for relativism. The latter treats all knowledge claims as equally valid. For Collins, however, one's position in the social matrix grants a particular perspective, and some perspectives give better insight into the phenomenon under investigation. For Césaire, the phenomenon is the racialized domination of colonialism. This new historical-critical consciousness is brought about by a new education-one that takes seriously the Archimedean point of contextualized everyday lived experience.

In this paper, I turn to Césaire's Discourse on Colonialism and suggest that his critique can still be useful for addressing neocolonial and racial injustice in the twenty-first century. First, I provide an account of Césaire's diagnosis of the brutality of colonialism and racialized capitalism. Second, I consider the role of the public intellectual. Many public intellectuals espouse a humanism that remains Eurocentric. However, for Césaire, there are positive future possibilities that the public intellectual can aid in making manifest, namely, the self-determination of colonized peoples, dialogue, and radical change of institutions for forming a nonmanichaean humanity.

\section{Creating a Politico-Aesthetic Imaginary}

Colonialism, as Césaire conceives it, is a totalizing scheme of inside/outside, of the systems of the colonizer and the interior life of the colonized. Colonization, for Césaire, is decivilization. It is he writes, "neither evangelization, nor a philanthropic enterprise, nor a desire to push back the frontiers of ignorance, disease, and tyranny, nor a project undertaken for the greater glory of God, nor an attempt to extend the rule of law." 8 What Charles Mills calls "the racial polity" refers to the system of domination in which races are categorized and ascribed value. The racial contract, which is what sustains the racial polity, is, for Mills, an epistemological contract. Where recognition is understood as an agreement, whites have agreed with one another not to

\footnotetext{
${ }^{7}$ Nikki Giovanni, Sacred Cows and Other Edibles (New York: William Morrow, 1988),

57.

8 Aimé Césaire, Discourse on Colonialism, trans. by Joan Pinkham (New York, NY: Monthly Review Press, 2000), 32.

(c) 2018 Mark W. Westmoreland

https://www.kritike.org/journal/issue 23/westmoreland december2018.pdf ISSN 1908-7330
}

(c) $)$ BY-NC-ND 
recognize black persons as persons of equal standing. And, as the contract attempts to protect property, whiteness itself becomes property. "Where whiteness itself becomes property," Mills claims, "nonwhites do not fully, or at all, own themselves, and nonwhite labor does not appropriate nature." 9 Nonwhiteness - or I'll say "blackess" for clarity - has instrumental value for whiteness. Du Bois's "wages of whiteness" name those benefits accrued to whites due to a racial polity that attaches whiteness to property. This has two steps: whiteness is defined as oppositional. Where white equals virtue and citizen, black equals vice and anticitizen, that is, a Caliban needing to be controlled. If whiteness is a differential entitlement or property, then blackness cannot be. To be clear, whiteness in this context, while not disassociated from identity, speaks to the material benefits that whiteness confers. In other words, whiteness means that one owns differential treatment in the social sphere (political, legal, economic, etc.). Put differently, the goal of the racial polity, which assumes black inferiority as natural/apolitical, is to continually subordinate nonwhite racial groups in the interest of serving whiteness. According to Sartre, one of Césaire's interlocutors, the nature of "Colonialism [is to deny] human rights to [those] whom it has subdued by violence, and keeps them by force in a state of misery and ignorance that Marx would rightly call a subhuman condition. Racism is ingrained in actions, institutions, and in the nature of the colonialist methods of production and exchange." 10 A civilization that accepts this is only nominally civilized. The West is Hitler and has been since the dawn of colonization. The Führer did not appear from nowhere; rather his stage was already set long before he arrived. He was the consequence of an already decadent, sick civilization. Césaire tells us that "no one colonizes innocently."11. In short, all of the West is Hitler and has been so centuries before 1933.

To colonize is to "thingify." The colonizer defends himself in the name of progress. What he does not accept is his culpability in dehumanizing a large portion of the world. However, when the West takes pride in curing diseases and improving standards of living, Césaire laments the "societies drained of their essence ... lands confiscated ... magnificent artistic creations destroyed, [and] extraordinary possibilities wiped out." 12 While the oppressor points to roads, canals, railroads, and other infrastructure, Césaire looks upon "thousands of men sacrificed...millions of men torn from their gods, their

\footnotetext{
${ }^{9}$ Charles Mills, The Racial Contract (Ithaca, NY: Cornell University Press, 1997), 96.

${ }^{10}$ Jean-Paul Sartre, Introduction to Albert Memmi, The Colonizer and the Colonized (Boston, MA: Beacon Press, 1965), xxiv.

${ }^{11}$ Césaire, Discourse, 39.

${ }^{12}$ Ibid., 43.
}

(c) 2018 Mark W. Westmoreland https://www.kritike.org/journal/issue 23/westmoreland december2018.pdf ISSN 1908-7330 


\section{CÉSAIRE'S REVOLUTION OF PEDAGOGY}

land, their habits, their life." 13 The West sees trade and agricultural expansion. Césaire sees "food crops destroyed, malnutrition permanently introduced...about the looting of products [...] of raw materials." 14 The cynegetic logic of racism and colonialism results in only exploitation and domination. There are colonials and there are things.

The figure of Caliban in Shakespeare's The Tempest, given a voice of his own by Césaire, marks the present human condition, that is, the dialectical relation between reason and antimodernity that is part of a larger colonial project. The Caliban problem, explains Negri in The Savage Anomaly, is "the problem of the liberatory force of natural imagination." 15 The Caliban figure functions as the limit of reason. The problem for moderns is how best to deal with those who do not share the same epistemic and normative framework. For Negri, this problem is twofold: to what extent is imagination a means through which we navigate the vicissitudes of life and to what extent does the imagination play a role in the constitution of soul and world. In Commonwealth, Negri, along with Michael Hardt, explains how modern rationalism developed concurrently with the monstrous. The latter, for Hardt and Negri, names the antimodernity that grounds modernity's Caliban problem. These antimodern monsters-the forces allegedly threatening European enlightenment-were becoming all too familiar. Journal entries describing cannibalism, tales of human sacrifice, and reports of witches tormenting the hillside fed into the narrative of Europe's need to control such "creative powers" either by slavery, witch hunts, or colonialism. Cannibalism and sacrifice, albeit outside of Europe, pointed to a disposition of "cruelty, violence, and madness," while witches, both external and internal to Europe, were the manifestation of "irrationality and superstition, betraying reason and religion." 16 These monsters were met with one of two responses: either Europe tried to control them or it chose to disregard them, naming them "illusions, figments of an overheated imagination." 17 The figure of Caliban marks the present human condition, that is, the dialectical relation between reason and antimodernity that is part of a larger colonial project.

At the edge of the map, beyond the cartography of reason, here there be monsters-hic sunt dracones. In other words, "the dialectic brings the relationship to a standstill" in that modernity is equated with progress circumscribed by the stagnation of antimodernity. ${ }^{18}$ In their retort, Hardt and

\footnotetext{
13 Ibid.

${ }^{14}$ Ibid.

${ }^{15}$ Antonio Negri, The Savage Anomaly: The Power of Spinoza's Metaphysics and Politics, trans. by Michael Hardt (Minneapolis, MN: University of Minnesota Press, 1991), 86.

${ }_{16}$ Michael Hardt and Antonio Negri, Commonwealth (Cambridge, MA: Harvard University Press, 2009), 95.

17 Ibid.

${ }^{18}$ Ibid., 96.

(C) 2018 Mark W. Westmoreland

https://www.kritike.org/journal/issue 23/westmoreland december2018.pdf

ISSN 1908-7330
}

(c) BY-NC-ND 
Negri suggest that the problems of the Frankfurt description can be avoided. Rather than being in contradiction, rather than being oppositional, antimodernity has a diagonal relation to modernity. It cuts across the narrative of modern progress by opening up new possibilities for human progress. "The monsters of liberation," Hardt and Negri write, "because the most powerful of them, and the ones that will interest us most, do not stand in a specular, negative relation to modernity but rather adopt a diagonal stance, [are] not simply opposing all that is modern and rational but [are] inventing new rationalities and new forms of liberation." 19

It was the black slave who signified antimodernity. The black slave had to be put to work within a system of white supremacy. Turning to Shakespeare's The Tempest, Hardt and Negri note how Caliban, as the savage monstrosity, will not be killed by Prospero since he and his daughter Miranda need Caliban:
We cannot miss him.
He does make our fire,
Fetch in our wood, and serves in offices
That profit us. ${ }^{20}$

Contra this portrait of Caliban, anticolonial authors and theorists like Césaire have used Caliban to signify the struggle of resistance against the empires of modernity. For example, in Césaire's retelling of $A$ Tempest, Caliban gains his freedom by breaking the Manichean chains that imprisoned him, chains that were both physical and psychological. Caliban realizes that, rather than being incompetent and irrational, he has a form of reason that runs diagonal to that of European modernity. Hardt and Negri summarize the tension between Prospero and Caliban quite well:

From the perspective of the European colonizers the monster is contained in the dialectical struggle between reason and madness, progress and barbarism, modernity and antimodernity. From the perspective of the colonized, though, in their struggle for liberation, Caliban, who is endowed with as much or more reason and civilization than the colonizers, is monstrous only to the extent that his desire for freedom exceeds the bounds of the colonial relationship of biopower, blowing apart the chains of the dialectic. ${ }^{21}$

\footnotetext{
${ }^{19}$ Ibid., 97.

${ }^{20}$ William Shakespeare, The Tempest, I.2.310-312.

${ }^{21}$ Hardt and Negri, Commonwealth, 98.
} 


\section{CÉSAIRE'S REVOLUTION OF PEDAGOGY}

Such horrors of controlling the magical monster were buttressed by the political imaginary of modernity - one that understood the other, that is, the Amerindian, the African, and so on, as the functional limit of reason, as the body in opposition to thought. The body was understood as an external marker of a threat to rationality; as such, it was associated with the devil. Surveying journals and other documents made by European explorers and traders, Anthony Barker concludes: "Devil worship and diabolical interventions were the most widely reported aspects of the non-European societies the slave traders encountered." 22 Any conjuration or agreement made between slaves and the indigenous underclass was seen by the slaveholders and merchants as akin to the pact made between the devil and a witch. Such Calibans are not to be tolerated in the white, racial polity.

Whiteness disguises its imaginary force as a sociopolitical construction by accounting for race in terms of nature, namely, what will later be the domains of biology and genetics. Whiteness names a set of power relations through which "human" is defined in relation to the monstrous other (Caliban) - the African Negroes, the cannibals, those who practice human sacrifice, those who practice divination and a malicious alchemy. These others are to be controlled and either placed in bondage or exterminated. But, this illustrates how modernity cannibalizes itself, how it is its very own opposite. Césaire writes: "That the West alone knows how to think; that at the borders of the Western world there begins the shadowy realm of primitive thinking, which, dominated by the notion of participation, incapable of logic, is the very model of faulty thinking." ${ }^{23}$ In other words, by thinking its own rationality superior to others, modernity reveals itself as a monstrosity. For Mills, it is from the exclusion of others - the antimodernsthat the modern notion of the human-the liberal subject or the autonomous individual-is established in modernity. In the racial polity, for whites the game is to include whiteness and exclude the other.

"Every day that passes," Césaire writes, "every denial of justice, every beating by the police, every demand of the workers that is drowned in blood, every scandal that is hushed up brings home to us the value of our old societies." 24 And yet, he does not call for a return to the democratic and cooperative cultures of precolonial Africa. In Discourse, there is no call to revert to a premodern condition; there is no retreat to the past. Like Frantz Fanon after him, Césaire offers not naïve nostalgia but revolution. To return would be to repeat a history that cannot survive in the present; it is simply

\footnotetext{
${ }^{22}$ Anthony J. Barker, The African Link: British Attitudes to the Negro in the Era of the Atlantic Slave Trade, 1550-1807 (Totowa, NJ: Frank Class, 1978), 91.

${ }^{23}$ Césaire, Discourse, 64.

${ }^{24}$ Ibid., 44.

(c) 2018 Mark W. Westmoreland

https://www.kritike.org/journal/issue 23/westmoreland december2018.pdf

ISSN 1908-7330
}

(c) BY-NC-ND 
exoticism. For Césaire, the goal is not to choose from the preexistent options but to construct a way of life, a style, an aesthetics of the existence, to create something new by embracing both "the productive power of modern times" and "the fraternity of the olden days." 25

\section{Pedagogues and Public Intellectuals}

Robin D.G. Kelley's introduction to Césaire's Discourse ends with a powerful description of Césaire's text: It "never intended to be a road map or a blueprint for revolution. It is poetry and therefore revolt. It is an act of insurrection .... It is a rising, a blow to the master who appears as owner and ruler, teacher and comrade. It is revolutionary graffiti painted in bold strokes." ${ }^{26}$ Discourse is no blueprint, but it is revolutionary, or, as Kelley describes it, "a declaration of war ... almost a 'third world manifesto'." 27 Just as Césaire challenged his contemporaries and called for revolutionary practices that would put an end to colonization, its corrupt institutions, and its dehumanizing policies, his words still speak truth to a world marred by neocolonialism, rampant inequalities, and perverse capitalism, which, according to Marx, began with the cynegetic practice of hunting of black skins. Many of the social ills that confronted Césaire have yet to be remedied; not "every denial of justice" has been answered. ${ }^{28}$ Nevertheless, his call for resistance and revolution continues to encourage and challenge us to create "a humanism made to the measure of the world," a world with parity of participation among all. ${ }^{29}$

In Toward the African Revolution, Fanon asks, "Have I not, because of what I have done or failed to do, contributed to an impoverishment of human reality?" 30 Like Marx, Fanon realized the task before him was to change the world and not only to interpret it. The public intellectual's task is to improve human reality, to change the world, by placing herself in medias res alongside those suffering under, for example, the steel grip of racism or imperialism. This is not easily done for the intellectual is already in a double bind and is caught within a web of contradictions. The public intellectual, according to Sartre, receives her vocation from no one; her function is not mandated to her. The dominant, bourgeois class recognizes the public intellectual only as an intellectual in so far as she is a technician of knowledge whose task it is to

${ }^{25}$ Ibid., 52.

${ }^{26}$ Robin D.G. Kelley, "A Poetics of Anticolonialism," Introduction to Aimé Césaire, Discourse on Colonialism, trans. by Joan Pinkham (New York, NY: Monthly Review Press, 2000), 28.

${ }^{27}$ Ibid., 7.

${ }^{28}$ Césaire, Discourse, 44 .

${ }^{29}$ Ibid., 73.

${ }^{30}$ Frantz Fanon, Toward the African Revolution (New York, NY: Grove Press, 1967), 3.

(c) 2018 Mark W. Westmoreland https://www.kritike.org/journal/issue 23/westmoreland december2018.pdf ISSN 1908-7330 


\section{CÉSAIRE'S REVOLUTION OF PEDAGOGY}

perpetuate the advantages of the dominant class. As a "custodian of tradition," she is expected to be conservative. ${ }^{31}$ At the same time, the underprivileged class views her with much skepticism. She gets her own advantage, namely, education and sufficient employment, from the surplus value produced by the exploitation of the lower class by the dominant class. Any solidarity she may show toward this class meets distrust as she "is not one of us, she cannot understand our oppression." The middle class, of which she belongs, shares her contradictions but ignores them and welcomes the present ideology. The middle-class mass clamors "I too can be successful. I can be wealthy. I can have power." as if these things came about solely through a liberalism, colorblind and naïve, that buys into the idea that "if I only work hard enough, nothing can stand in my way." But, there is something in the way for the underclass and the racially oppressed, namely, the white supremacist patriarchy. Colonialism did not emerge from happenstance. It was not some accidental, historical enigma of Western civilization. Rather, it proceeded from the logic that undergirds the Eurocentric monologue of the West. It is against this monologue, which Césaire addresses in the final section of Discourse, that Négritude stands as a corrective, as one piece of what we might call a transformative remedy.

The public intellectual has a second problem, namely, his position. Trying to investigate himself and the conditions of which he is a product, the public intellectual lacks a view from the outside. If he wants to properly grasp the situation, then, according to Sartre, "he has only one course open to him and that is to adopt the point of view of its most under-privileged members," who, by their very existence, condemn the dominant ideology. ${ }^{32}$ While adopting this view, the public intellectual takes on several tasks, namely:

1. To struggle against ideology's rebirth

2. To elevate popular culture

3. To aid the underprivileged class in creating technicians of practical knowledge

4. To realize that the democratization of knowledge, freedom of thought, and truth are ends shared by all

5 . To demonstrate that immediate aims fall short of our ultimate objectives

6. To guard the "historical ends pursued by the masses, against all political power 33

\footnotetext{
${ }^{31}$ Jean-Paul Sartre, "Plea for Intellectuals," in Between Existentialism and Marxism (New York: William Morrow, 1976), 238.

32 Ibid., 235.

${ }^{33}$ Ibid., 262-263.

(c) 2018 Mark W. Westmoreland

https://www.kritike.org/journal/issue 23/westmoreland december2018.pdf

ISSN 1908-7330
}

(c) BY-NC-ND 
Noting these tasks reminds us that theory and practice do not belong to separate spheres. There is no pure theory; theory is a practice. Césaire and others were already doing this. Fanon, Léopold Senghor, and other Négritude artists were already turning an antiracist, anticolonial theory into a revolution of minds and a revolutionary aesthetics of existence.

There is nothing original in my claim that colonialism was destructive and abhorrent. In The Notebook of a Return to the Native Land, Césaire writes,

At the end of daybreak, life prostrate, you don't know how to dispose of your aborted dreams, the river of life desperately torpid in its bed, neither turgid nor low, hesitant to flow, pitifully empty, the impartial heaviness of boredom distributing shade equally on all things, the air stagnant, unbroken by the brightness of a single bird. ${ }^{34}$

While the colonial system brought a cloud of darkness over the earth, the selfdetermination of the colonized gave and still gives us hope that brighter days are possible. But before such bright days come, the unheard must become heard. The pedagogue must, as Spivak suggests, learn to learn from below. Those below know that the new world, which lingers at the end of history, comes about at the end of this world. Such a new pedagogy would, in Césaire's view, bring down the reign of Prospero.

Césaire writes in response to the monologue of white normative and white supremacist thinking: "And the voice [that is, the voice of Africa] complains that for centuries Europe has force-fed us with lies and bloated us with pestilence, for it is not true that the work of man is done, that we have no business being on earth, that we parasite the world." 35 The European Prospero sees the Calibans of the world as a threat to the cosmic order of whiteness. In reply, Caliban speaks:

Prospero, you are the master of illusion.

Lying is your trademark.

And you have lied so much to me

(lied about the world, lied about me)

that you have ended by imposing on me

an image of myself.

Underdeveloped, you brand me, inferior,

${ }^{34}$ Aimé Césaire, Notebook of a Return to the Native Land (Middletown, CT: Wesleyan University Press, 2001), 9.

${ }^{35}$ Ibid., 44.

(c) 2018 Mark W. Westmoreland

https://www.kritike.org/journal/issue 23/westmoreland december2018.pdf

ISSN 1908-7330

(cc) BY-NC-ND 


\title{
32 CÉSAIRE'S REVOLUTION OF PEDAGOGY
}

that's the way you have forced me to see myself.

I detest that image! What's more, it's a lie!

But now I know you, you old cancer, and I know myself as well. ${ }^{36}$

Césaire, like Du Bois before him, rejects Prospero's colonizing claim: modern European civilization destroyed the beautiful cultures of Africa and, once politically and socially free, the Negro peoples will again create a new way of life, a new "humanism made to the measure of the world." 37

\section{Revolution}

Revolution transforms the potential into the actual. In the era of decolonization, "revolution was [a] way of life," a way of renewing the realm of the possible. ${ }^{38}$ What was becoming actualized was not simply access to subsistence, not simply the struggle for bare life; but, also, it was a struggle for dignity, for recognition of "[the negroes'] full human value." 39 The primary condition for the creation of dignity, value, and culture, according to Césaire, is destruction - the end of the world - a revolution. Césaire writes in Notebook:

\author{
What can I do? \\ One must begin somewhere. \\ Begin what? \\ The only thing in the world \\ Worth beginning: \\ The End of the world of course. ${ }^{40}$
}

Let me briefly lay out a historical account of revolution and what this might mean for the twenty-first century. First, revolution is not synonymous with war nor should it be confused with revolt. Human histories are full of wars, but revolutions came about only in the recent past. While they might be violent, they are not carried out in order to acquire the resources of another

36 Aimé Césaire, A Tempest, trans. by Richard Miller. (New York, NY: Theatre Communications Group, Inc., 2002), 61-62.

${ }^{37}$ Césaire, Discourse, 73.

${ }^{38}$ Adolfo Gilly, Introduction to Frantz Fanon, A Dying Colonialism (New York: Grove Press, 1965), 1.

${ }^{39}$ Ibid., 58.

${ }^{40}$ Césaire, Notebook, 22.

(c) 2018 Mark W. Westmoreland

https://www.kritike.org/journal/issue 23/westmoreland december2018.pdf

ISSN 1908-7330

(c) BY-NC-ND 
people, as is often common in wars, nor are they pursued solely for the sake of regime change; in other words, revolutions are not coup d'etat. When Louis XVI saw the beginnings of what would become the French Revolution, he called it a revolt. This was just two days before the storming of the Bastille. A French Duke, standing next to the king responded, "Sire ... it is not a revolt, it is a revolution." 41 (Williams 272). What this little anecdote shows is how revolution was beginning to take on a new meaning and one that we should ask whether or not is still fitting for our contemporary time.

The term revolution has a wide lexical range. It may refer to planetary cycles, such as the orbit of the earth around the sun, for example. It may refer to groundbreaking shifts in paradigms, as when, for instance, we speak of the Copernican revolution in science or the Kantian revolution in philosophy. In addition, an older notion of political revolution may be found in the ancient Greeks and Romans but such a revolution was linked with the natural order of the world. This older notion of revolution held that one regime or constitution at a time could structure the polis. The regimes might emerge in cycles, one replacing another in a continuous political orbit, but nothing radically new was created. What was lacking in this sort of revolution was a transformation of the social order.

Modern revolution, however, involves both political and social newness. Furthermore, it does not participate in a recurring cycle. According to Hannah Arendt, "the modern concept of revolution, inextricably bound up with the notion that the course of history suddenly begins anew, that an entirely new story, a story never known or told before, is about to unfold, [that!] was unknown prior to the two great revolutions at the end of the eighteenth century." 42 Revolution is seen here, not as a return to an earlier state of affairs, but as a radical break from previous modes of social and political life. This unprecedented event opens up an unknown future in which society is reconfigured or transformed. In the modern context of the decolonization, the question remains whether political emancipation or liberation also involves social progress and freedom-the freedom to determine one's own destiny. Such freedom or self-determination cannot arise from mere reforms since reforms do not dismantle the architecture of systemic oppression. As remedies, they might tweak this or that, but, if the foundation of society is already unjust, the rest of the house will remain tainted. Revolution, however, is the beginning of a transformative remedy that "aim[s] at correcting inequitable outcomes precisely by restructuring the

${ }^{41}$ Raymond Williams, Keywords: A Vocabulary of Culture and Society (New York: Oxford University Press, 1985), 272.

${ }^{42}$ Hannah Arendt, On Revolution (New York, NY: Penguin Books, 2006), 18-19.

(c) 2018 Mark W. Westmoreland

https://www.kritike.org/journal/issue 23/westmoreland december2018.pdf

ISSN 1908-7330

(cc) BY-NC-ND 


\section{CÉSAIRE'S REVOLUTION OF PEDAGOGY}

underlying generative framework" of society. ${ }^{43}$ This restructuring involves more than minor, surface reforms. Reforms might lessen the negative effects of colonization and systemic racism but they will not abolish them. A remedy is transformative on two counts in the way that it produces parity of participation. It attempts to significantly restructure both the relations of production so that material conditions are equalized, so that resources such as wealth and opportunity are evenly distributed, and also the relations of recognition so that all members of society are seen as equal peers.

\section{Intellectuals and Revolution}

"What Césaire destroys," Sartre suggests, "is not all culture but rather white culture; what he brings to light is not desire for everything but rather the revolutionary aspirations of the oppressed negro; what he touches in his very depths is not the spirit but a certain specific, concrete form of humanity." 44 The soul of revolution is imagination and Césaire, as a public intellectual, helped develop a critical consciousness for the wretched of the earth. The imagination opens up new possibilities in both thought and practice, new changes in human social interaction. Revolutionary aspirations find their actualization in the work of the oppressed masses, who alone are the miraculous weapons of liberation. Often, the biggest hindrance is the "decent fellow," or the white moderate, or the false intellectual. ${ }^{45}$ The public intellectual, however, serves as a corrective. She is from the middle class, same as the "decent fellow," and can challenge the moderate's acceptance of the dominant ideology. Whereas the moderate says no to radical change, no to violent revolution, no to the abolition of capitalism, the Sartrean public intellectual, of which Césaire is paradigmatic, says "if all I can do is speak, it is for you [the colonized, that] I shall speak." 46 Where white supremacist patriarchy attempts to fragment the oppressed, thereby rendering them mute, the revolutionary poet, the public intellectual, gives unreserved "support [to] the national aspirations of colonized peoples." 47 While the liberal focuses on reforming society in order to reduce individual racism, Césaire, according to André Breton, is "a black who is not only a black but of all of [humankind], who conveys all of [our] questionings, all of [our] anguish, all of [our] hopes and all of [our] ecstasies, and who will remain more and more [...] the prototype of dignity" that stands defiantly before the monster that is systemic

${ }^{43}$ Nancy Fraser, Justice Interruptus: Critical Reflections on the "Postsocialist" Condition (New York, NY: Routledge, 1996), 23.

${ }^{44}$ Sartre, "Black Orpheus," 127.

${ }^{45}$ Césaire, Discourse, 47.

${ }^{46}$ Césaire, Notebook, 13.

${ }^{47}$ Fanon, Toward the African Revolution, 76.

(C) 2018 Mark W. Westmoreland

https://www.kritike.org/journal/issue 23/westmoreland december2018.pdf

ISSN 1908-7330

(c) BY-NC-ND 
racism. ${ }^{48}$ It is from being one from below, one of the wretched, that one can speak for all in so far as he gives voice to what whiteness tried to make invisible. And finally, what is this new kind of dignified life? What is the alternative to liberal reform? What is the concrete alternative? These questions are meaningless in so far as there is no a priori blueprint. Before the revolution begins and in the midst of revolution itself, the revolutionary actors do not have a view of the future of this world. They call for its end. Césaire's Discourse is not a blueprint, but it does provide a ground upon which we can imagine a new body politic, one that is generated from within the ranks of the colonized. The colonized know the end of the world, and yet, at the same time, know of a "humanism made to the measure of the world."

Department of Philosophy, Villanova University, USA

\section{References}

Arendt, Hannah, On Revolution (New York, NY: Penguin Books, 2006).

Barker, Anthony, The African Link: British Attitudes to the Negro in the Era of the Atlantic Slave Trade, 1550-1807 (Totowa, NJ: Frank Cass, 1978).

Breton, André, "A Great Black Poet," in Aimé Césaire, Notebook of a Return to the Native Land (Middletown, CT: Wesleyan University Press, 2001).

Césaire, Aimé, A Tempest, trans. by Richard Miller (New York, NY: Theatre Communications Group, Inc., 2002).

"Culture and Colonization," Social Text, 28:2 (2010).

Discourse on Colonialism, trans. by Joan Pinkham (New York, NY:

Monthly Review Press, 2000). Notebook of a Return to the Native Land (Middletown, CT:

Wesleyan University Press, 2001).

"The Thoroughbreds," in The Collected Poetry, trans. by Clayton

Eshleman and Annette Smith (Berkeley, CA: University of California

Press, 1983).

Drabinski, John E., "Césaire's Apocalyptic Word," South Atlantic Quarterly, 115:3 (2016).

Fanon, Frantz, Toward the African Revolution (New York, NY: Grove Press, 1967).

Fraser, Nancy, Justice Interruptus: Critical Reflections on the "Postsocialist" Condition (New York, NY: Routledge, 1996).

Freire, Paulo, Pedagogy of the Oppressed (New York: Continuum, 2007).

48 André Breton, "A Great Black Poet," in Notebook of a Return to the Native Land (Middletown, CT: Wesleyan University Press, 2001), xii.

(c) 2018 Mark W. Westmoreland https://www.kritike.org/journal/issue 23/westmoreland december2018.pdf ISSN 1908-7330 


\section{CÉSAIRE'S REVOLUTION OF PEDAGOGY}

Gilly, Adolfo, Introduction to Frantz Fanon, A Dying Colonialism (New York: Grove Press, 1965).

Giovanni, Nikki, Sacred Cows and Other Edibles (New York: William Morrow, 1988).

Hardt, Michael, and Antonio Negri, Commonwealth (Cambridge, MA: Harvard University Press, 2009).

Kelley, Robin D.G, "A Poetics of Anticolonialism," Introduction to Aimé Césaire, Discourse on Colonialism, trans. by Joan Pinkham (New York, NY: Monthly Review Press, 2000).

Mills, Charles, "Racial Polity," in Blackness Visible (Ithaca, NY: Cornell University Press, 1998). The Racial Contract (Ithaca, NY: Cornell University Press, 1997).

Negri, Antonio, The Savage Anomaly: The Power of Spinoza's Metaphysics and Politics, trans. by Michael Hardt (Minneapolis, MN: University of Minnesota Press, 1991).

Sartre, Jean-Paul, "Black Orpheus," in Race, ed. by Robert Bernasconi (Malden, MA: Blackwell, 2001).

Introduction to Albert Memmi, The Colonizer and the Colonized (Boston, MA: Beacon Press, 1965). "Plea for Intellectuals," in Between Existentialism and Marxism (New York: William Morrow, 1976).

Shakespeare, William, The Tempest, in The Riverside Shakespeare: The Complete Works, $2^{\text {nd }}$ ed. (Boston, MA: Houghton Mifflin, 1997).

Walker, Alice, In Search of Our Mother's Gardens, (San Diego, CA: Harcourt Brace Jovanovich, 1983).

Williams, Raymond, Keywords: A Vocabulary of Culture and Society (New York: Oxford University Press, 1985).

(c) 2018 Mark W. Westmoreland https://www.kritike.org/journal/issue 23/westmoreland december2018.pdf ISSN 1908-7330

\section{(c) ) BY-NC-ND}




\title{
Sundays with Roque: A Tale of Friendship and Companionship
}

Tomas G. Rosario, Jr. ${ }^{1}$

\begin{abstract}
Sundays with Roque" is partly narrative, mainly reflective essay patterned after the best-selling memoir Tuesdays with Morrie. Like Tuesdays with Morrie, which tells the inspiring story of the relationship between writer Mitch Albom and his professor Morrie Schwartz, this narrative-reflective essay is about the equally inspirational bond between Leovino Garcia and his former professor Fr. Roque Ferriols, S.J. Their relation is a tale of friendship and companionship that manifest extraordinary commitment, fidelity, and sacrifices from both parties in their mutual care and dynamic love for one another. What is most noteworthy, however, in "Sundays with Roque," is that it serves as a call, even an appeal, to the present generation to recognize the principal value of companionship in caring for our elderly family members and our friends.
\end{abstract}

Keywords: Aristotle, Aquinas, Ferriols, Garcia

7 uesdays with Morrie $^{2}$ is an unusually inspirational memoir which became an international best-seller when it was published in 1997. I was given a copy of this book as a fitting birthday gift in the year 2000 by a former student from Davao city. She had apparently looked up to me not only as her teacher but also as her guardian because I took care of her as a resident student of Eliazo Hall for four years. Perhaps, she had viewed her relation with me and my influence on her during her four-year academic life

${ }^{1}$ Tomas G. Rosario, Jr. was a full professor in the Department of Philosophy at the Ateneo de Manila University. He finished his PhD in Philosophy from the University of Santo Tomas in 1990 and did postdoctoral studies at the Katholieke Universiteit Leuven in Belgium in 1994. Known for his translations of the Summa of Thomas Aquinas from Latin to Filipino, he also specialized on the thoughts of Richard Rorty. He was 67 years old when he died last 6 December 2017. The editor of this essay is Mark Joseph T. Calano, Coordinator for Research and Creative Works of the School of Humanities and Assistant Professor of Philosophy at the Ateneo de Manila University. Inc., 1997).

2 Mitch Albom, Tuesdays with Morrie (New York: Doubleday Dell Publishing Group,

(c) 2018 Tomas G. Rosario

https://www.kritike.org/journal/issue 23/rosario december2018.pdf

ISSN 1908-7330

(cc) $\mathrm{BY}-\mathrm{NC}-\mathrm{ND}$ 


\section{SUNDAYS WITH ROQUE}

in Ateneo as a relatively noteworthy instance of the more ennobling bond between the two main figures in the memoir: author Mitch Albom and Morrie Schwartz, a retired university professor suffering from a serious type of sclerosis.

The book is a chronicle of Mitch Albom's Tuesday visits to his very ill former mentor. These visits have been highlighted by discussions on fundamentally human issues, such as marriage, family, feeling sorry for oneself, regrets, emotions, fear of aging, forgiveness, giving love, and, of course, death. But more than an academic nostalgia, this unexpected reunion between a favorite student and a greatly admired teacher has turned out to be a rediscovery of something truly noble in the personality not only of the forgotten teacher but also of the forgetful and ambitious former student. Their Tuesday dialogues have been opportunities to be reflective on two subjects that Mitch finally realized to be the most crucial in life but which he failed to seriously think about when Morrie raised them in his classes, namely, "being human" and "relating to others." ${ }^{3}$ Mitch recalls in the book that these topics sounded strange and distant when he was a young university student.

As such, the Tuesday visits have provided Mitch with a now-ornever chance to relearn about being human from Morrie. The book thus abounds with words of philosophical wisdom. On the fourth Tuesday visit, for instance, when they dwelt on death, Morrie points out to Mitch: the "imminence of death makes us see our lives in a radically different way." 4 Once, he evokes Socrates as when he gave a paradoxical lesson: "Learn how to die, and you learn how to live." 5 In every conversation with Morrie, Mitch learns something new. In one conversation, he realizes that Morrie had been aware of his ambitious disposition and conduct. ${ }^{6}$ There is no doubt that Morrie was deeply concerned then about Mitch's preoccupation with what he called the "egotistical concerns" 7 of the $20^{\text {th }}$-century American culture, characterized by what we learned from Marcel as the goods of having, such as career, money, owning a luxurious house in a rich village, a new car, and the like. If Morrie has frankly called Mitch's attention about the latter's ambitiousness, it is only because he is genuinely concerned for his wellbeing. A particularly memorable wisdom from Morrie is his conviction that "the most important thing in life is to learn how to give out love, and to let it come in" 8 which demonstrates that he viewed "being human" as centrally constituted by a loving communion with fellowmen. His idea of giving out

\footnotetext{
${ }^{3}$ Ibid., 17.

${ }^{4}$ Ibid., 83.

${ }^{5}$ Ibid.

${ }^{6}$ Ibid.

${ }^{7}$ Ibid, 64 .

8 Ibid., 52.
}

(C) 2018 Tomas G. Rosario

https://www.kritike.org/journal/issue 23/rosario december2018.pdf ISSN 1908-7330

(c) BY-NC-ND 
love need not entail great sacrifices as it may just be ordinary gestures like allotting someone time to provide companionship and engage in storytelling. ${ }^{9}$ It is probably because of this deep insight on love that Morrie finds hope that his death does not entail separation from Mitch insofar as Morrie's love continues to dwell in his heart ${ }^{10}$ and energizes him to serve other people and his community. ${ }^{11}$ It is this love, i.e., the love of people who patiently care for him, that protected and strengthened Morrie against self-pity and despair. ${ }^{12} \mathrm{He}$ displayed great hope in spite of his daily sufferings and of his knowledge of the incurable character of his illness.

From this brief narrative of Tuesdays with Morrie, which features insightful dialogues between the teacher and his former student, I am reminded of another true story of exemplary bond between a Jesuit priest, Roque Ferriols, and his former student, Leovino Garcia. Based on Garcia's own account, Ferriols had assumed the task of serving as his protective guardian and mentor since he started his college education up to the time that he gained the honor of becoming an Ateneo faculty member. Ferriols never relented in the succeeding years, not only to guide and support Garcia in the performance of his tasks and in the realization of the university vision when he became an administrator at the Ateneo de Manila University, but also to vigorously defend him when confronted with detractive criticisms of his academic leadership by certain faculty members and even by other university administrators.

Now, what I have observed for more than twenty years and continue to witness today is the faithful and patient devotion of Garcia not only to look after the physical wellbeing of Ferriols in view of the latter's old age, but also, and especially, to spend quality time with him. As we have seen above, this spending of quality time is, according to Morrie, one of the noble gestures of loving commitment. But perhaps what makes Garcia's tireless caring attention for Ferriols all the more praiseworthy and exemplary is his unchangeable and unconditional dedication to lovingly serve his mentor and spiritual father in spite of the widely known volatile temperament of the latter. I, myself, have witnessed the outburst of the fiery anger of Ferriols on several occasions when I was his student pursuing a master's degree in Philosophy and during the initial years of my teaching career in Ateneo. But it will be an unjust narrative of my personal encounters with Ferriols if I do not take note of my experiences of the gentle, warm, and generous aspects of his personality.

\footnotetext{
${ }^{9}$ Ibid., 126.

10 Ibid., 174.

${ }^{11}$ Ibid., 127.

${ }^{12}$ Ibid., 36.
} 


\section{SUNDAYS WITH ROQUE}

Ferriols's deteriorating physical health necessitated the reduction of his teaching load and his transfer to the infirmary area of the Loyola House of Studies where a 24-hour immediate attention is provided by the medical staff. Yet, in spite of this professional medical service available to Ferriols, Garcia has reserved Sunday afternoons to visit and to be with him. It was on one Sunday afternoon that I was able to accompany Garcia in his selfprescribed schedule of visits and noticed then that Ferriols has lost much energy of mobility, yet he obviously has the fortitude to be as active as he could be.

Perhaps, if one were to adhere to Marcel's nonrational mode of thinking, one would find that there is a mysterious way by which Ferriols draws strength from his regular communion with Garcia. It is, in fact, unusual that health experts do claim, on the basis of their latest studies, that social gatherings or the time spent relaxing or chatting with friends have been found to be a major factor in minimizing, if not preventing, ailments related to the heart. What we see in this claim is a clear reliance on the principle of causality, which is under the purview of rational justification, in the scientific effort to articulate the abovementioned established connection between gregariousness and one's wellbeing.

Our main interest, however, in adopting Garcia's Sunday moments with Ferriols as an appropriate model of companionship, is to try to explore the values and virtues which can be drawn from these visits of companionship and which, upon reflection, could be shown to be constitutive of moral wisdom. If there are lasting lessons of relationships that we could gain from this narrative, then, "Sundays with Roque" deserves to be considered as an inspiring story.

We may begin with companionship itself. In his treatise on happiness, Thomas Aquinas has considered societas amicorum, ${ }^{13}$ or the companionship of friends, as one of the essential elements of legitimate happiness in our earthly life. Consider the following justification:

If we speak of present-life happiness ... then the happy man must have friends. It is not that he makes use of them ... but that he needs them in order that he may act well, namely, that he may do them good, that he may take delight in seeing them do good, and also that they may help him in his good works, and also that they may

13 Thomas Aquinas, Summa Theologica of St. Thomas, trans. by Fathers of the English Dominican Province (New York: Benziger Brothers, Inc., 1947), I-II.4.8. Hereafter cited as Summa Theologica.

(c) 2018 Tomas G. Rosario

https://www.kritike.org/journal/issue 23/rosario december2018.pdf

ISSN 1908-7330

(c) BY-NC-ND 
help him in his good works, for he needs their support in both the active and contemplative life. ${ }^{14}$

St. Thomas himself acknowledges in the same passage his reliance on the teaching of Aristotle regarding the vital role of the companionship of friends in having a good and happy life. ${ }^{15}$ This acknowledgement of the saint leads us, then, to Aristotle's treatise on friendship which could help us in the understanding of the abovementioned passage and in the articulation of the Sunday companionship of Garcia with Ferriols.

First of all, Aristotelian scholars should be familiar with the teaching of Aristotle that friendship is a virtue and that it is indispensable in having a good life. ${ }^{16}$ Now, what appears to be central to his conception of friendship is that it is none other than mutual goodwill. ${ }^{17}$ This position, in fact, implies his conviction that we should not consider someone as a friend unless we desire what is good for his own sake. ${ }^{18}$ But, employing the rational tool of distinction which St. Thomas may have inherited from Aristotle, the latter clarified that goodwill should not be confused with friendship since he deemed it essential to the notion of friendship that one's goodwill should be reciprocated by the beneficiary. We may conclude from this definite conception of friendship that two individuals can be considered as friends only if they seek respectively what is truly good for one another. It should be added, however, that Aristotle should also mean in his essential conception of friendship that the mutual goodwill should be active and dynamic in character. Goodwill must involve energetic effort to attain the desired good of the beloved.

What we have seen so far as the chief teaching of Aristotle on friendship is that it signifies mutual goodwill such that the goal of goodwill is none other than the true good of the beloved. It is, in this sense, that friendship is essentially associated with what is good in a dual sense, namely, the goodwill of the benevolent person and the wellbeing of the beloved.

Moreover, we may highlight another relevant insight of Aristotle on friendship: that "... loving seems to be the characteristic virtue of friend...." 19 This is tantamount to an affirmation that friendship is a relationship of love so that the other person in the relation of friendship is someone who is

${ }^{14}$ Ibid.

${ }^{15}$ Aristotle initially observed that friends "... are thought the greatest of external goods" [Aristotle, Nicomachean Ethics, in The Basic Works of Aristotle, ed. by Richard McKeon (New York: Random House, 1941), IX.9.1169b10]. Then in reference to the 'happy man,' he declared that "...it is better to spend his days with friends and good men than with strangers or any chance persons. Therefore, the happy man needs friends." [Ibid., IX.9.1169b20.].

${ }^{16}$ Ibid., VIII.1.1155a5.

17 Ibid., VIII.2.1155b30-1156a5.

${ }^{18}$ Ibid., VIII.2.1155b30.

${ }^{19}$ Ibid., VIII.7.1159a35. 


\section{SUNDAYS WITH ROQUE}

beloved. ${ }^{20}$ Aristotle did not mean, however, that the beloved refers to any family member, or to any relative, or to an individual who is the object of one's romantic affection. I do not think that Aristotle has a parochial conception of the beloved other in the relation of friendship. In fact, it was also his clear teaching that the object of one's goodwill is someone who "has been found lovable." ${ }^{21}$ If we ask what, for him, constitutes the loveableness of both parties in friendship, Aristotle was also definite in his reply that it is "in virtue of their goodness." 22 In other words, good men are loveable because they are good or morally upright.

Now, Aristotle has considered the friendship of good men as the true and perfect form of friendship. ${ }^{23}$ Since the persons involved in this friendship are men of goodwill, their friendly companionship will endure for as long as both of them continue also to be good and righteous. ${ }^{24}$ But, if true friendship is exclusively exemplified by men of goodwill, this immediately impresses on us that most men are not engaged in honorable friendship due to self-serving interests. Aristotle himself admitted that the friendship of good men is uncommon, since, although this is a questionable view, men of virtue are very few in the society. ${ }^{25}$ But what could serve as a positive rejoinder to the abovementioned admission that seemed to erode his preference for the friendship of good men is his own claim that true friendship takes time to develop, but it is attainable. In other words, since Aristotle has viewed friendship as one of the moral virtues, ${ }^{26}$ imperfect forms of friendship like friendship of utility or friendship of pleasure could undergo a metamorphosis towards the realization of the perfect friendship of men of goodwill.

Finally, we must not fail to point out that friendship entails equality ${ }^{27}$ even in inequality. ${ }^{28}$ First of all, friends are equal in terms of the good that they desire and they obtain reciprocally. ${ }^{29}$ Aristotle made this specifically clear with his teaching that it is in the case of perfect friendship wherein there

\footnotetext{
${ }^{20}$ In relation to this, St. Thomas himself held the view that "...love consists chiefly in this, that the 'lover desires the good of the beloved'." Thomas Aquinas, Summa contra Gentiles, trans. by Brian Davies (New York: Oxford University Press, 2016), III.90. See also Aquinas, Summa Theologica, I.20.1-2.

${ }^{21}$ Aristotle, Nicomachean Ethics, VIII.3.1156b25-30.

22 Ibid., VIII.4.1157b35.

${ }^{23}$ Aristotle referred to other forms of friendship such as the friendship of utility and the friendship of pleasure, both of which he considered as transient and vulnerable to dissolution. Ibid., VIII.3.1156a5-20.

${ }^{24}$ Ibid., VIII.3.1156b10.

${ }^{25}$ Ibid., VIII.3.1156b25.

${ }^{26}$ Ibid., VIII1.1155a5.

${ }^{27}$ Ibid., VIII5.1157b35, 1158b.

${ }^{28}$ Ibid., VIII8.1159b5.

${ }^{29}$ Ibid., VIII6.1158a5.

(c) 2018 Tomas G. Rosario

https://www.kritike.org/journal/issue 23/rosario december2018.pdf

ISSN 1908-7330
}

(cc) BY-NC-ND 
is "an equal return in goodwill and in pleasantness." 30 This declaration shows that Aristotle has not referred to physical factors like age, economic status, or position of influence in speaking of equality in friendship. Now, in speaking of equality in mutual goodwill and in pleasant companionship, he impressed on us the view that goodwill is the equalizing factor in friendship. This means that inequality or difference in age or in socio-economic status is overcome due to the goodwill, in particular, of the partner in friendship who is either more advanced in age or who occupies a position of superiority or authority in the society. It is, in fact, our common experience that goodwill easily stimulates mutual goodwill and, in itself, is the source of tranquil delight associated with a high level of happiness. In this sense, then, we could say that goodwill is the primary principle which undermines all barriers to friendship and which serves also as probably the most effective cause of communion or of durable and nobly pleasant companionship.

Against the background of our consultation on Aristotle's treatise on friendship, we could notice, if we go back to the passage on companionship of friends drawn from St. Thomas's treatise on happiness, that it is focused also on what is good in speaking of the happy man's need for friends. But what is remarkably significant is the consonance of the two thinkers' conception of friendship in terms of the good: just as Aristotle has spoken of friendship as the virtue of willing the good of the beloved friend, St. Thomas has seen it as an opportunity for mutual support or cooperation to do good deeds. Now, this fundamental concord between the Aristotelian and Thomistic theories of friendship could help in our reflection on the extraordinary story of Garcia's Sundays with Roque.

At this stage of our reflection, we may now say that the relation between Garcia and Ferriols falls under what Aristotle described as the friendship of good men. It might be the case, however, that Garcia does not relate himself as a friend, in the common sense of this word, to Ferriols, but that he esteems highly and reveres greatly the latter as his guardian and adviser, as the source of wise counsels, principles, and life lessons. Nonetheless, it is undeniable that it is the principle of goodwill that truly governs their relationship. Garcia himself has confided, in many occasions, to his close friends and even to his colleagues, the demonstration of his goodwill in terms of the unconditional care and the many sacrifices of Ferriols not only when he started his teaching career in Ateneo, but also during the many difficult years when he occupied a major administrative position in the university as he contributed to the promotion of its academic mission and goals.

${ }^{30}$ Ibid., VIII5.1157b35.

(c) 2018 Tomas G. Rosario

https://www.kritike.org/journal/issue 23/rosario december2018.pdf

ISSN 1908-7330

(cc) BY-NC-ND 


\section{SUNDAYS WITH ROQUE}

Garcia's Sundays with Roque might be viewed as an instance of the Filipino value of utang na loob. But, if the sociological analysis of utang na loob as part of the Filipino social culture is valid, then it could be abused to manipulate and even enslave someone with a debt of gratitude. ${ }^{31}$ This Filipino value, then, must be reexamined in order to explore and discover its possibly principal character as a moral value. To assist in attaining this goal, let us consult the pertinent teachings of Dietrich von Hildebrand. According to him, when I am grateful to someone, my gratitude is indicative of two things: the first is that an objective good for me as a human person is the result of the good action of the other person to whom I am grateful; the second is that "gratitude also refers to the morally noble attitude of my benefactor which manifests itself in his bestowing the benefit on me." 32 What we see in these teachings of Hildebrand is that when one is grateful, the response of gratitude is directed to and is an acknowledgement of the intentio benevolentiae ${ }^{33}$ or the goodwill of the individual who has done a good deed which generates what is truly good for him as an individual human person. He was also categorical in his affirmation that the benevolent intention or goodwill is directed to the person or persons we love. ${ }^{34}$ Furthermore, gratitude necessarily presupposes the value of moral goodness of the doer of the good act.

What strikes our interest in these teachings of Hildebrand is that they confirm at least one of the main teachings of Aristotle, namely, that goodwill is directed to the person we love. But what is more significant is his position that gratitude is not only a recognition by the grateful person of the true good which he has received, but also of the morally good intention of the doer of the good act. This teaching of Hildebrand is crucial, for it means that the Filipino value response of utang na loob, if we go beyond the sociological view, has a meaning that perhaps properly pertains to the sphere of morality. Following Hildebrand's doctrine on the relation of gratitude to the intentio benevolentiae of the doer of the good act, utang na loob should signify a moral debt-if we follow St. Thomas, ${ }^{35}$ - to the goodwill of the benevolent agent. But this moral indebtedness is neither manipulative nor enslaving, since, if it could be either, it would contradict the very principle of goodwill. In other words, it is thoroughly inconsistent with one's benevolent intention for the

\footnotetext{
${ }^{31}$ Evelyn Miranda-Feliciano, Filipino Values and our Christian Faith (Mandaluyong: OMF Literature Inc., 1990), 70.

${ }^{32}$ Dietrich von Hildebrand, Christian Ethics (New York: David McKay Company, Inc., 1953), 50 .

${ }^{33}$ Ibid., 59.

${ }^{34}$ Ibid.

${ }^{35}$ St. Thomas clearly taught that it is in accordance with justice that as a beneficiary of good act one should know "... gratitude, whereby a debt is paid to benefactors ...." Aquinas, Summa Theologica, I-II.60.3.

(C) 2018 Tomas G. Rosario

https://www.kritike.org/journal/issue 23/rosario december2018.pdf

ISSN 1908-7330
}

(cc) BY-NC-ND 
beloved to bind him or her to one's demands and wishes through regular reminders of the big favors one has bestowed upon him or her.

Following this ethical study, the goodwill is attributed to a morally upright agent whose intention for doing a good act for another person is not tainted by self-gratifying actual result or future benefit for the said doer of the act. It is in the moral sense then that we could consider Garcia's Sundays with Roque as an act of utang na loob.

It is unfair, however, to view Garcia's utang na loob to Ferriols as nothing but a demonstration of what St. Thomas has called the moral obligation to be grateful. For, as we have already noted above, Garcia has quietly demonstrated bountiful concern and patient commitment to care for Ferriols for probably more than three decades by now. We should turn instead to St. Thomas' treatise on God's love in order to articulate Garcia's morally relevant affection for Ferriols. We learn in this treatise that, "to love a person is to will good for that person," 36 which we notice to be essentially similar to the position of Aristotle. Now, just as it is the principle of goodwill that moved Ferriols when he attended to and looked after the personal and professional welfare of Garcia, especially during the adjustment years of his teaching career, the same principle continues to animate Garcia's indefatigable attentive visits to Ferriols. It is very significant to note at this stage of our reflection that Garcia's devotion to care for Ferriols is a clear proof that goodwill generates mutual goodwill.

Hence, we may make the definitive claim that it is at the level of mutual goodwill, or what St. Thomas referred to as the superior love of friendship, ${ }^{37}$ which characterizes the relation of Ferriols and Garcia, which is undoubtedly similar to the relation of mutual loving care between Morrie and his student Mitch.

Now, we may initially note as a moral lesson in life, our wisdom story that this extraordinary bond of mutual goodwill between Ferriols and Garcia is a forceful reminder to promote what is commonly acknowledged as a value ordinarily associated with family life: this is none other than the caring for the elderly. It is truly very unfortunate that in a widely secularized society today characterized by mobility, anonymity, and obsession with success, the care for the elderly is either relegated to institutions like "Home for the Aged," or, if they stay with their own family, they do not receive adequate attention, especially the care which is vital to their psychological and social wellbeing. It is, I believe, an eminent testimony of magnanimous self-giving for Garcia to take upon himself the loving commitment to personally attend to Ferriols, although the latter belongs to a religious community whose

${ }^{36}$ Ibid., I-II.20.1, ad 3. See also I-II.20.2 and I-II.20.3.

${ }^{37}$ Ibid., I-II.20.2, ad 3.

(c) 2018 Tomas G. Rosario

https://www.kritike.org/journal/issue 23/rosario december2018.pdf

ISSN 1908-7330

(cc) BY-NC-ND 


\section{SUNDAYS WITH ROQUE}

members are supposed to be mandated by the rules of their religious life to cultivate the sort of companionship appropriate to a religious society inspired by Jesus Christ.

Moreover, this true story of mutual goodwill is an extraordinary affirmation of what was claimed in Tuesdays with Morrie as the most important thing in life, namely, to give out love and to be open to receive it in spite of the fact that the abovementioned individuals involved do not have family ties. This indicates that there is a truly noble and great reason or principle transcending the blood relationship which is the common basis for bestowing care and support for the elderly or for someone close to us. We already referred to this noble reason and moral principle as the principle of goodwill. Our consultation of the related teachings of Aristotle, St. Thomas, and Hildebrand helped us see that it is this principle which mutually motivated Ferriols and Garcia to be dedicated in their active concern for each other's welfare.

It was the opinion of Aristotle that it is rare to find good men whom he considered as the only ones capable of cultivating mutual goodwill. But, if his skepticism on the promotion of goodwill among men has any plausibility, it would mean that the Ferriols-Garcia story of friendship of good men should be considered as an isolated case. Aristotle, however, may have overstated his negative perception of the possible expansion of mutual goodwill among members of the society for we may raise, at least, my personal experiences of noble friendship and companionship with former dorm scholars from various parts of the country who are still in regular contact with me to express our relative opposition to Aristotle's position. In fact, I could still recall Garcia's advice to me, when I was designated as Director of the Residence Halls through his recommendation: that is, not to fail to take care of dorm scholars for, one day, they will reciprocate my goodwill. And I must not fail to add another corroborating personal experience, for it shows that the mutual goodwill and companionship between Ferriols and Garcia could be a positively contagious and self-propagating example, that is, that Garcia has expanded his goodwill to me: he unconditionally assisted me towards the promotion of my teaching career and he has also provided me with the opportunities to rise from being an unknown Ateneo faculty to being acknowledged and honored as one of the best teachers of the university.

These evidences lead us now to the last point. Finally, and most of all, this wisdom story, "Sundays with Roque," in hindsight, serves to corroborate what I have envisioned as probably the principal categorical imperative of a philosophy teacher: that he/she is more a guardian of goodwill than a guardian of philosophically sanctioned truth. As a guardian of goodwill, I am convinced that Ferriols, Garcia, myself, and the new generation of philosophy teachers could contribute to the vision of building

(c) 2018 Tomas G. Rosario

https://www.kritike.org/journal/issue 23/rosario december2018.pdf

ISSN 1908-7330

(c) $)$ BY-NC-ND 
a solidarity of mutual goodwill, at least, with our students and with one another.

Department of Philosophy, Ateneo de Manila University, Philippines

\section{References}

Albom, Mitch, Tuesdays with Morrie (New York: Doubleday Dell Publishing Group, Inc., 1997).

Aristotle, Nicomachean Ethics, in The Basic Works of Aristotle, ed. by Richard McKeon (New York: Random House, 1941).

Aquinas, Thomas, Summa contra Gentiles, trans. by Brian Davies (New York: Oxford University Press, 2016).

Summa Theologica of St. Thomas, trans. by Fathers of the English Dominican Province (New York: Benziger Brothers, Inc., 1947).

von Hildebrand, Dietrich, Christian Ethics (New York: David McKay Company, 1953).

Miranda-Feliciano, Evelyn, Filipino Values and our Christian Faith, (Mandaluyong: OMF Literature Inc., 1990). 
On Filipino Philosophy

\title{
Ferriols at Heidegger: Ang Pagbigkas sa Kasaysayan bilang Talagang Nangyayari
}

Marc Oliver D. Pasco

\begin{abstract}
This essay aims to view the philosophy of Roque J. Ferriols, from a Heideggerian perspective. It argues that Ferriols' way of philosophizing may be appreciated by illuminating it with Heidegger's authentically historical way of philosophizing. Heidegger's Wiederholung or creative retrieval of Ancient Greek philosophy is evident in Ferriols' own approach in thinking meron. Both hold that genuinely historical philosophical thinking may not be reduced to a historiographical approach to philosophizing, akin to Nietzsche's account of the antiquarian approach to history. To wit, it may be argued that Ferriols' way of thinking is somehow similar to Heidegger's insofar as it desires to perform its own unique way of creatively retrieving the meaning of meron from its authentically historical roots as talagang nangyayari, as thought and lived out in the Filipino context. Ferriols' pagbigkas sa meron resonates with Heidegger's call to retrieve the historically forgotten meaning of Sein.
\end{abstract}

Keywords: kasaysayan, talagang nangyayari, Wiederholung, pagbigkas sa meron

\section{Si Ferriols bilang Istoryador ng Pilosopiya}

$\mathrm{M}$ alimit na nauunawaan ang kasaysayan bilang proseso ng paglipas ng panahon mula sa nakaraan, ang paghantong nito sa ngayon, at ang pagdako nito sa hinaharap. Madalas ding mas nabibigyangdiin ang yugto ng nakaraan sa prosesong ito, dulot na rin siguro ng pagkilala na sadyang mas may halaga ang mga bagay at pangyayaring hindi na maibabalik o mababalikan pa kaysa sa mga pangyayaring hawak pa at mababago pa sa ngayon at lalo na sa mga pangyayaring wala pa naman, at kung gayo'y hindi pa dapat isipin. Kung iisipin, ang ganitong pasulong at romantikong interpretasyon sa kasaysayan ay batay sa perspektibo ng tao bilang tagapagmasid ng mga pangyayari mula sa isang abot-tanaw na animo'y nasa labas o sumasaibayo sa kasaysayan mismo. Nahihiwalay ang

(C) 2018 Marc Oliver D. Pasco

https://www.kritike.org/journal/issue 23/pasco december2018.pdf

ISSN 1908-7330

(cc) $\mathrm{BY}-\mathrm{NC}-\mathrm{ND}$ 
tao sa kasaysayan sa ganitong pagtanaw. Hindi niya ito itinuturing bilang siyang mismong kinikilusang abot-tanaw ng lahat ng tungkol sa kanya, bagkus ay tinititigan niya ito sa mga pahina ng makakapal na libro ng kasaysayan, o 'di kaya'y sa mga webpage sa internet, na siyang nagtataguyod ng akademikong pagtingin sa kasaysayan bilang isang kuwentong binabasa ng isang mambabasa. Kung mananatili lamang tayo sa ganitong pananaw, hindi natin lubusang mapapahalagahan ang ambag ni Roque Ferriols sa kasaysayan, hindi lamang ng pilosopiyang Filipino, kundi sa pilosopiya mismo.

Sa bungad ng kanyang akdang Mga Sinaunang Griyego, inilista ni Ferriols ang mga kakailanganing katangian at kakayahan ng isang istoryador ng pilosopiyang handang makipagsapalaran at umunawa sa mga katutubong kaisipan ng mga sinaunang palaisip. ‘Ika niya:

Ang nasabing istoryador ay nangangailangan ng: 1) pagkaeksakto: nang huwag niyang baluktutin o pilipitin ang talagang iniisip ng pilosopong kanyang pinagaaralan 2) buhay na pagmumulat na kapuwa tao rin ang mga pilosopo 3) pagsisikap maging maunawain sa mga taong marahil ibang-iba sa kanya ang uri ng pag-iisip 4) pananabik matulungang magbukas ng kalooban nang magamit niya, ika nga, ang mga bahagi ng kanyang utak at puso na hindi niya nakaugaliang gamitin. ${ }^{1}$

Sa siping ito, malinaw ang iginagawad na pagpapahalaga ni Ferriols sa pagiging mulat at bukas sa abot-tanaw ng mga pilosopong ninanais nating maunawaan. Bukod sa kahilingang maging eksakto o tapat sa binigkas ng mga pilosopo ayon sa pag-unawa natin sa kanila bilang kapwa-taong may sariling ginagalawang konteksto, kapansin-pansin ang pagpapahalaga ni Ferriols sa papel ng istoryador bilang bukas, buhay, at dinamikong mambabasang handang ilagay ang kanyang sarili sa alanganin at paganahain ang mga bahagi ng kanyang pag-iisip at pag-unawang hindi niya kinasanayang gamitin alang-alang sa pagiging tapat sa pakikipagsapalaran sa kasaysayan. Wari ba'y pinaaalahanan tayo ni Ferriols na ang pakikipagsapalaran sa kasaysayan ng pilosopiya ay isang galaw ng sariling ginagabayan hindi lamang ng personal na kahiligan kundi ng mismong mga bukal ng pag-uunawang may kakayahan pa ring makipag-usap sa atin, sa ngayon maging, sa hinaharap. Para sa kanya, ang mga labi nina Herakleitos, Parmenides, Xenophanes, Platon, at Aristoteles ay mga buhay na

${ }^{1}$ Roque J. Ferriols, Mga Sinaunang Griyego (Quezon City: Office of Research and Publications, Ateneo de Manila University, 1991), 2. 
pagpapahayag ng mga diwang buhay na buhay pa rin sa ngayon. Hindi niya ito inaral dahil itinuring niya ang mga itong antigong labi na pinaka-iingatan niyang mapanatili sa kanilang dalisay na estado bilang luma at gayo'y mahalaga. Ang halaga ng mga labi ay nababatay sa kakayahan ng mga itong pukawin ang isip at diwa ng istoryador nang mabigkas niya ang meron nang ayon sa wasto nitong abot-tanaw.

Ang problematikong nais tugunan ng papel na ito ay ang paksang may kinalaman sa reduksyon ng kasaysayan sa ideya ng mala-Almanac na tambakan ng kronolohikal na pangyayari, hindi naiiba sa karakterisasyon ni Nietzsche sa kanyang maikling librong, On the Uses and Disadvantages of History for Life, sa antikwaryong pagtanaw sa kasaysayan. Ang ganitong pananaw ay nagpapa-bangkay sa kasaysayan, itituturing ito bilang isang ispesimen na binabalangkasan at pinapatawan ng mga makataong panukat na hindi kumikilala sa likas nitong wika at dinamismo. Sa palagay ko, makatutulong ang gagawing sabayang pagtalakay sa mga pilosopiya nina Ferriols at Heidegger sa pagbuhay sa intrinsikong dinamismo ng kasaysayan kapag ito'y inunawa sa lilim ng kanilang pag-unawa sa meron at Sein at ang relasyon nito sa makasaysayang pag-iral ng tao.

Nais ipakita ng sanaysay na ito na ang pamimilosopiya ni Ferriols ay tunay na makasaysayan sa ganang ito'y buhay at dinamikong pakikipagtalastasan hindi lamang sa mga sinaunang pilosopo, kundi sa meron mismo na patuloy na kumikilos at sumasanib sa ginagawa niyang pamimilosopiya. Sa gagawing pagtanaw sa pilosopiya ni Ferriols mula sa lente ng pamimilosopiya ni Martin Heidegger, susubuking ipakita ang pagkakahawig ng kanilang pamamaraan ng pamimilosopiya mula sa perspektibo ng pag-unawa sa kasaysayan bilang pakikipagsapalaran sa pamamagitan ng malikhaing pag-uulit sa pangyayari ng talagang nangyayari. Susubukin ding tingnan kung mapapalalim ni Ferriols ang diskurso ni Heidegger tungkol sa panahon ng modernong teknolohiya. Sa huli, layunin ng papel na ito na itaguyod ang isang larawan ni Ferriols bilang isang palaisip na tunay na kumilos sa abot-tanaw ng meron dahil siya ay nakipagsapalaran sa isang makasaysayang paraan sa talagang nangyayari at hindi lamang nagpa-akit sa kasiguruhan at malilinaw na hangganan ng konsepto. Gaya ng mismong sabi niya:

Ang pag-aalala naman sa meron ay pagbabalik sa isang pagmamalay-tao, na hindi iniwanan kailan man. Ano itong pagmamalay-tao na hindi iniwanan? Ang pagbigkas sa meron. Hindi ko ibig sabihin na kailangang sabihin ninoman: meron, merong ganito, merong ganoon. Ang buhay ninoman na mulat at gising sa talagang nagyayari ay pagbigkas sa meron. At mulat

(C) 2018 Marc Oliver D. Pasco

https://www.kritike.org/journal/issue 23/pasco december2018.pdf ISSN 1908-7330

(c) $)$ BY-NC-ND 
siya sa isang malalim, hindi-konsepto at lihim na pagmamalay na binibigkas nga niya ang meron. ${ }^{2}$

Para kay Ferriols ang pag-aalala ay isang kilos ng pagbabalik sa mismong sarili ng tao. Kapag inaalala natin ang meron sa pamamagitan ng pagbigkas dito, nangyayari ang pagiging tao ng ating pagkatao at nakikisalamuha't sumasabak tayo sa daluyong ng kasaysayang patuloy na humahamon sa ating lumikha ng isang matinong sariling marunong bumigkas sa wika ng meron na talagang makasaysayan.

\section{Ang Meron bilang Paksang Historikal: Pag-uulit ayon kina Ferriols at Heidegger}

Para sa palaisip na si Martin Heidegger, mainam na linawin ang pagkakaiba ng kahulugan ng dalawang salitang Aleman para sa kasaysayan, ang Historie at Geschichte. Ang Historie ay tumutukoy sa kasaysayan bilang historiyograpiya o ang disiplinado at siyentipikong pag-aaral sa mga pangyayari sa nakaraan at ang mga kaugnayan ng mga ito, samantalang ang Geschichte ay may kinalaman sa mismong pangyayari ng mga pangyayari batay sa "bigay" o pagtatakda ng Sein o ng pagprepresensya ng nagprepresensya. Ayon kay Heidegger, "chronological distance and causal sequence do indeed belong to the study of historiography, but are not themselves history." ${ }^{3}$ Ang kasaysayan, bilang Geschichte ay ang kasaysayan ng Sein o Seinsgeschichte. Inungkat ni Heidegger ang etimolohikal na relasyon ng salitang Geschichte sa Geschick na nangangahulugang "destining" o pagtatakda. Ayon kay William Lovitt, isang tagapagsalin ng mga akda ni Heidegger, "the word Geschick can mean fate or destiny. Furthermore, the word Schickung, which denotes a 'providential decree or dispensation,' is closely related to Geschick. Another term, the verb, sich schicken, which means 'to come to pass' or 'happen,' 'to suit or to be fit' is also related to Geschick." ${ }^{4}$ Mula sa pananaw na ito, masasabing para kay Heidegger, ang kasaysayan, bilang kasaysayan ng

\footnotetext{
2 Roque J. Ferriols, SJ, Pambungad sa Metapisika (Quezon City: Office of Research and Publications, Ateneo de Manila University, 1997), 13.

3Martin Heidegger, "The Anaximander Fragment," in Early Greek Thinking, trans. by David Farrell Krell and Frank Capuzzi (San Francisco: Harper San Francisco, 1984.), 26. Dagdag pa ni Michael Inwood, “The German language has two words for 'history', Geschichte and Historie. Both refer ambiguously to history as events or happenings and to history as the study of events. Heidegger disambiguates them, assigning Geschichte to events, 'history', and Historie to the study of events, 'historiology, the 'historian.' His choice is not arbitrary: Geschichte comes from geschehen, 'to happen', while Historie comes from the Greek historein, 'to enquire, etc."' Michael Inwood, A Heidegger Dictionary (Malden: Blackwell Publishers, 1999), 90.

${ }^{4}$ Martin Heidegger, "The Turning," in The Question Concerning Technology and Other Essays, trans. by William Lovitt (New York: Harper and Row Publishers, 1977), 37.
} 


\section{FERRIOLS AT HEIDEGGER}

Sein ay may kinalaman sa pangyayari ng mismong Sein bilang paglalantadsabay-kubli ng pagprepresensya ng nagprepresensya na siyang kondisyon ng posibilidad ng anumang ispesikong pangyayari sa kasaysayan mula sa lente ng historiyograpiya.

Ang Sein ay nangyayari, bagamat nakakubli. Sa pagkakakubli ng paprepresensya sa taong nakatanod dito, nahuhulog ang tao sa kapalaran ng paglimot (Seinsvergessenheit) dahil natututok ang kanyang atensyon sa mga nagprepresensya at hindi sa mismong pagprepresensya ng mga ito. Kumbaga, batay sa pag-unawa sa kasaysayan bilang Geschichte, malinaw ang kakayahan ng taong umunawa at makisangkot sa mga pangyayari sa kasaysayan gaya ng mga rebolusyon at digmaan, ngunit salat siya sa kamulatan sa saysay ng mga ito sa abot-tanaw ng mismong pangyayari ng mga ito na nababatay sa laro ng litaw-sabay-kubli ng katotohanan o alêtheia. Hindi lubusang kakulangan o kasalanan ng tao ang kanyang paglimot, kundi ito ay buhat sa mismong esensya ng Sein bilang siyang nagkukubli ayon sa pagtatakda na rin Geschick ng Sein mismo. Paglilinaw ni Heidegger:

When we use the word Geschick in connection with be-ing, then we mean that being hails us and clears and lights itself, and in clearing it furnishes the tem-poral play-space wherein beings can appear. In light of the Geschick of being, the history of being is not thought of in terms of a happening characterized by a passing away and a process. Rather, the essence of history is determined on the basis of the Geschick of being, of being as Geschick, of what as such proffers itself to us in withdrawing. Both-proffering and withdrawingare one and the same, not two different things. ${ }^{5}$

Ang nauunang pagtatakda ng Sein ang naghahanda ng espasyo at panahon para sa pangyayari ng kasaysayan. Sa pangyayari ng kasaysayan bilang Geschichte nagiging posible ang pakikipagtagpo sa mga umiiral na siya namang kinakanlong ng kanyang pag-uunawa. Para kay Heidegger hindi mauunawaan ang esensyal na kahulugan ng Sein (na siyang proyekto ng kanyang pamimilosopiya) nang hindi sabay inuunawa ang esensyal na kahulugan ng kasaysayan bilang ang pangyayari ng katotohanan. Wika niya, "History means, again at first appearance arbitrarily, the happening [Ereignis] of a decision about the essence of truth. The manner in which the whole of beings is

${ }^{5}$ Martin Heidegger, The Principle of Reason, trans. by Reginald Lilly (Indianapolis: Indiana University Press, 1996), 62.

(c) 2018 Marc Oliver D. Pasco

https://www.kritike.org/journal/issue 23/pasco december2018.pdf

ISSN 1908-7330

(c) $)$ BY-NC-ND 
revealed, in which man is allowed to stand in the midst of this revelation, is grounded and transformed in such a decision." 6

Sa madaling salita, ipinaliliwanag ni Heidegger na hindi tulad ng kinasanayang kaisipan, hindi tao ang ultimong tagapagtakda ng saysay ng kasaysayan, bagkus, ang anumang interpretasyon at pag-uunawa niya sa mga pangyayaring kinasasangkutan niya sa kasaysayan ay masasabing tugon sa nauna nang pagtatakda ng Geschick ng Sein na nagtataguyod ng parametrong bumabalangkas sa mga bagay na kanyang pag-uukulan ng pansin at isasaloob pati na sa mga aspeto ng mga bagay at pangyayaring hindi niya mapapansin. Bilang halimbawa, sa panahon ng modernong teknolohiya, ang saysay ng mga bagay ay batay sa kanilang pagiging handang magamit at pagkakitaan. Walang kakayahan ang tao na bumaling sa ibang aspeto ng mga nagprepresensya (gaya ng angking 'di matatawarang halaga at ganda ng kalikasan) dahil nakakahon ang kanyang kakayahang pumansin at umunawa sa kuwadro ng mismong yugto ng kasaysayan kung saan ang mga umiiral ay tinitingnan lamang bilang likas-yaman o puhunan.

Kung gayon, masasabi na para kay Heidegger, ang kasaysayan ng Sein ay ang kasaysayan ng paglimot ng tao sa mismong bukal ng kasaysayan na walang iba kundi ang Sein mismo. Sa bawat yugto ng kasaysayan, mula sa panahon ng mga sinaunang Griyego, sa panahong Medyibal, sa panahon ng Aufklärung, hanggang sa panahon ng modernong teknolohiya at ngayon sa panahon ng impormasyon, ipinagkakait ng Sein ang sarili nito (epoché) sa kilos ng pagkukubli pabor sa paglalantad ng mga umiiral nang ayon sa espiritu ng panahong itinakda ng Geschick ng Sein mismo. Nasa mismong esensya (das Wesen) ng Sein ang pagkanakakubli nito mula sa pag-iisip ng tao, at mula sa esensyang ito nakaugat ang panawagan sa malikhaing pag-uulit at pag-aalala (Wiederholung) sa Sein bilang yaong palaging nagkukubli.

Wiederholung o malikhaing pag-uulit at pag-aalala ang paraan ng pag-iisip ni Heidegger sa kasaysayan ng Sein. Ito ay ang kumakatawan sa kanyang pagsusumubok makipagsapalaran sa kasaysayan ng Sein bilang pangyayaring itinatakda ng pagkukubli ng mismong dapat pag-isipan. Ang Wiederholung o pagsundo (holen) muli (wieder) ay ang muling pagtatanong sa pundamental na tanong na parating nalilimutang itanong sa awtentikong paraan sa bawat yugto ng kasaysayan: Ano ang Sein? ${ }^{7}$ Nais niyang muling

${ }^{6}$ Martin Heidegger, Basic Concepts, trans. by Gary E. Aylesworth. (Indianapolis: Indiana University Press, 1993), 17.

7 Isinasalin ko ang Wiederholung na may literal na kahulugang "to fetch again," bilang pagsundong muli sapagkat mababakas sa pilosopiya ni Heidegger lalo na sa mga sanaysay niya sa librong Introduction to Metaphysics at Early Greek Thinking na ang kanyang pakikipagtapatang muli sa mga sinaunang Griyego gaya nina Anaximander, Heraclitus, at Parmenides ay naglalayong ipakita na marami pang posibilidad ang nagkukubli't dapat hayaang marinig muli ayon sa sariling huni ng katutubong wika na maaaring gamitan ng awtentikong pageetimolohiya ng mga salita gaya ng logos at einai. Sinusundong muli ni Heidegger ang naririto 


\section{FERRIOLS AT HEIDEGGER}

sunduin ang tanong na ito mula sa historikal na bukal ng tanong sa panahon ng mga sinaunang Griyego tulad nina Herakleitos at Parmenides hindi dahil sa isang romantikong pagbibigay-halaga sa simula dahil sa pagiging simula nito kung hindi dahil nais niyang pakinggan ang orihinal na abot-tanaw ng tanong mula sa mga labi ng mga unang palaisip na hindi lamang nag-isip kundi dumanas nito upang makapagsimula tayong, na nasa ngayon, na makipagsapalaran at makisangkot sa pundamental na tanong nang may pagkilala at pag-amin sa ating sariling pagkalimot. Sabi niya, "But we do not repeat a beginning by reducing it to something past and not known, which need merely be imitated; no, the beginning must be begun again, more radically, with all the strangeness, darkness, insecurity that attend a true beginning." ${ }^{8}$ Sa palagay $\mathrm{ni}$ Heidegger, sa pamamaraang ito lamang mabubuksan ang ibang posibilidad at paraan ng pakikisangkot natin sa kasaysayan ng mga umiiral at ng Sein mismo dahil sa paraang ito lamang tayo magiging bukas sa mga hindi pa nabigkas at hindi pa nasabi sa kasaysayan ng Sein dahil na rin sa esensya nito bilang nagkukubli. Paliwanag ni George Seidel:

Thus does Heidegger return to the thought of Parmenides and Heraclitus; not simply because their thought still supports our world, but also because in understanding them we understand where thinking with reference to being-for this is how one comes to stand authentically in his philosophical traditionsomehow went off-track; we must also return to the PreSocratics, says Heidegger, if we are to build historically anew. This return to tradition is no mere restoration or uncreative imitation. Heidegger is not striving to promote some sort of Renaissance of pre-Socratic thinking, even if this would be possible. He studies Parmenides and Heraclitus in an attempt to regain our authentic origins, such that our own thinking may be projected in an authentically historical manner into the future. ${ }^{9}$

\footnotetext{
na sa ngayon mula sa nakaraan upang bigyan ng panibagong pagdanas ang tao sa mga simpleng salitang ito na matagal nang natabunan ng tradisyunal na metapisikal na pag-iisip mula pa kay Platon hanggang kay Nietzsche. Kapag sinabing sinusundo muli ang isang tao, halimabawa, may implikasyon na parang may naiwan o nakaligtaan pa o 'di kaya'y naihatid siya sa maling lugar at kailangang dalhin sa orihinal na destinasyon. Sa parehong paraan, sinusundo muli ni Heidegger ang mga binigkas na kataga ng mga sinaunang Griyego upang makahanap ng mas angkop na landas para sa mga ito sa konteksto ng ngayon.

${ }^{8}$ Martin Heidegger, An Introduction to Metaphysics, trans. by Ralph Manheim (New York: Yale University Press, 1959), 39.

${ }_{9}^{9}$ George Joseph Seidel, Martin Heidegger and the Pre-Socratics (Lincoln: University of Nebraska Press, 1964), 121.
}

(c) 2018 Marc Oliver D. Pasco

https://www.kritike.org/journal/issue 23/pasco december2018.pdf

ISSN 1908-7330

(c) BY-NC-ND 
Ganito ang pamamaraan ng makasaysayang pakikipagsapalarang ginawa ni Heidegger sa kanyang pamimilosopiya. May malinaw siyang pagkilala sa mga nakatagong posibilidad na ikinukubli ng kasaysayan sa pag-iisip ng pilosopo at nakita niyang obligasyon ng mga nag-iisip na hayaang makahinga at makapagsalita ang mga nalimutang kahulugan ng mga binigkas ng mga sinaunang palaisip. Para sa kanya, ang mga simpleng kataga, gaya ng esti gar einai ni Parmenides at logos ni Herakleitos ay mga makasaysayang pagbigkas ng tao sa Sein. Sa madaling salita, nais ni Heidegger na tumalab muli ang esensyal na kahulugan ng Sein sa atin dito sa ngayon sa pamamagitan ng malikhaing pag-uulit ng mga tanong na binigkas sa nakaraan nang sa gayo'y maging tunay na makasaysayan ang ating pakikipagsapalaran patungo sa ating hinaharap.

Kung babasahin ang Mga Sinaunang Griyego at Pambungad sa Metapisika ni Ferriols sa lilim ng pagtanaw ni Heidegger sa makasaysayang pagbigkas sa Sein, mababakasan natin ang hawig na pamamaraan ng pakikisangkot sa kasaysayan ng pamimilosopiya. "Ika niya, "Ugali ng mga namimilosopiya na bumuo ng bagong salita, dala ng pangangailangan ng udyok ng pag-iisip. Ngunit, madalas, hindi sila nag-iimbento ng bagong huni, kundi kumukuha ng dati at kilalang huni at ginagamit ito sa bagong paraan. At ang bagong paraan ay may kaugnayan sa mga nakaugalian nang paraan, ngunit iba pa rin. At iba sapagkat iyan ang hinihingi ng paguunawa." ${ }^{10}$ Dagdag pa niya:

Ang sining ng pamumuhay na mulat sa meron, ay sining ng wasto at buhay na pagtatanong. Sa panahon na isinisilang ang isang wika, ang mga taong lumilikha't humuhubog sa wika ay nakatatanggap ng biyaya ng bago at sariwang pagkalito sa meron, ng orihinal na pagtatanong. Ang biyayang ito'y nag-iiwan ng bakas sa mismong wika. Ang buod ng bawat wika ay ilan mga kataga na mga labi, mga bakas, ng sinaunang pagtatanong. At sinumang gumagamit ng anomang wika, ay may kakayahang magtiyagang hanapin ang mga katagang buod, upang buhayin muli ang sinaunang paghahanap at pagkalito na nakatago sa mga katagang iyon ... parang apoy na nakatago sa baga. At maaaring ulitin ang mga mga katagang iyon.

Ganito ang pag-uulit sa wika: hanapin, gisingin, pairalin ang pagtataka, ang mapaglikhang pagkalito na nakatago

${ }^{10}$ Roque J. Ferriols SJ, Pambungad sa Metapisika, 113.

(c) 2018 Marc Oliver D. Pasco https://www.kritike.org/journal/issue 23/pasco december2018.pdf ISSN 1908-7330 


\section{FERRIOLS AT HEIDEGGER}

sa mga katagang buod. Magiging bago at sariwa uli ang wika, Matutuklasan ng umuulit na ang wika ay potensyal sa pag-unawa at paglikha sa meron. Magiging bago at sariwa ang pakikihalubilo sa meron ng taong umuulit sa anomang wika." 11

Inaalingawngaw ng pahayag nito ang sinabi ni Heidegger na, "ways of thinking hold within them that mysterious quality that we can walk them forward and backward, and that indeed only the way back will lead us forward." 12

Sa pakikipagbuno ni Ferriols sa mga labi ng mga palaisip tulad nina Parmenides at Herakleitos, sinubukan niyang tapat na bigkasin muli ang mga nabigkas na sa ngalan ng pagtalima niya sa meron na siyang paksa ng mga binigkas ng mga palaisip ng sinaunang panahon. Maingat niyang hinimay ang bawat taludtod ng mga tula ni Parmenides at sinikap humabi ng isang makasaysayang kuwento mula sa mga ito na tigib ng mga tinawag niyang pahiwatig o hudyat. Nabakasan niya ang pagsusumubok ni Parmenides na gumamit ng talinghaga sa pagbigkas sa meron na hindi kayang sabihin sapagkat sadyang tigib-apaw ang meron. ${ }^{13}$ Paano nasabing makasaysayan ang muling pagbigkas ni Ferriols sa mga nasabi na ng sinaunang pantas? Sapagkat sa kanyang pagsusumubok makipagsapalaran sa isang banyagang abot-tanaw at kausapin ito mula sa abot-tanaw ng Filipino, masasabing lumikha si Ferriols ng sariwang paraan ng pagtataka at pag-uusisa sa isang paksang kung tutuosin ay luma at lipas na. Sa kanyang pagsundo muli sa mga kataga ng sinaunang Griyego, sumibol ang isang sariwa at malikhaing pakikipagtapatan ng diwang Filipino sa diwa ng mga sinaunang Griyego. Sa kanyang pagbabalangkas ng mga labi ni Herakleitos na kilala sa pagiging malabo (ho skoteinos), nabuhay muli ang diwa ng logos para sa atin sa kasalukuyang panahon at natanto natin na may nabubuo nga sa paghihidwaan. Ang metodo ng pag-uulit ni Ferriols ay may kinalaman sa pag-angkas sa mismong abot-tanaw ni Herakleitos at sa huli'y subuking gumalaw sa abot-tanaw ng mismong meron. ${ }^{14}$ Ang logos na siyang sinaunang pagtitipon (legein) na nagbibigay saysay sa pagpapakita ng mga naghihidwaan ay ang mismong gabay ni Ferriols sa kanyang pagsasalin at pakikipag-diskurso sa mga labi. Sa madaling salita, kumilos ang logos sa bigkas ni Ferriols kaya't masasabing tunay na pangyayari ang naganap sa kanyang pag-iisip - talagang nangyari at nangyayari pa rin ang mga bigkas ni Ferriols--makasaysayang tunay. Naging bago at sariwa muli ang wikang

\footnotetext{
${ }^{11}$ Ibid., 43. Ang italisasyon at ellipses ay kay Ferriols.

${ }^{12}$ Martin Heidegger, "A Dialogue on Language," in On the Way to Language, trans. by Peter D. Hertz (New York: Harper and Row Publishers, 1971), 12.

${ }^{13}$ Ferriols, Mga Sinaunang Griyego, 50-68.

${ }^{14}$ Ibid., 27.
}

(C) 2018 Marc Oliver D. Pasco

https://www.kritike.org/journal/issue 23/pasco december2018.pdf

ISSN 1908-7330

(c) BY-NC-ND 
kanyang kinaharap (wikang Griyego) at kasabay nito, nanariwa rin ang wikang Filipino na sumubok umangkas sa abot-tanaw ng wika ng logos ng Sein noong unang panahon. At dito napapatunayan ang sinabi ni Ferriols na, "Walang labas ang abot tanaw ng meron; o, kung gusto mo, walang tunay na labas ang meron. Ang maaari lamang mangyari ay baka ako matauhan na nasa meron na nga pala ako. At magtataka ako na lalo pala itong mahiwaga kaysa sa inakala ko." 15

Binibigkis sina Herakleitos at Parmenides, ng mismong meron sa mga pahiwatig nito na mababakasan sa mismong mga pagtatangkang pagbigkas ng tatlong palaisip. Meron ang paksa ng logos ni Herakleitos, meron din ang tinutukoy ng perpektong bilog ni Parmenides, kung kaya't si Ferriols, na imbestigador ng meron, ay madaling naka-angkas sa ibig nilang sabihin. Lahat sila ay nakipagsapalaran sa kasaysayan, sa esensyal nitong kahulugan bilang pangyayari. Ang pangyayari ng meron ay walang iba kundi ang paglalantad-sabay-kubli ng meron mismo na humihiling ng makasaysayang pagbigkas sapagkat tanging meron lamang ang paksa ng kasaysayan, ang paksa ng mga paksa. Sabi ni Ferriols, "Kapag nasakyan na natin ang meron bilang paksa, makikita natin na ang meron ang dapat tawaging tunay na paksa; paksa ng mga paksa; mas sinauna kaysa sa anomang sinauna. Sapagkat lahat ng mga ibang paksa: maganda, mabuti, totoo, tao, hayup, musika, salita at kahit na ano ... ay paksa lamang kung meron at palibhasa'y meron. Kung hindi meron, wala. At ang wala ay wala." ${ }^{16}$ Sa makasaysayang pagbigkas sa meron, nailalantad ng wika ang nakakubling misteryo ng meron na siyang paksa ng lahat ng paksa. Nahahayaang tipunin ng logos ang mga paghihidwaang bumubuo at lumilinaw ang papel ng tao sa pangyayaring ito na siyang bumubuo sa kasaysayan sa esensyal nitong kahulugan bilang saksi at daluyan ng wika ng meron na maipapamalas niya hindi lamang sa salita kundi mas lalong higit sa paggawa. Tulad ng paalala ni Ferriols, "Ang pagbigkas na tugon sa tawag ng meron, hindi maaaring manatili sa isip lamang. Kailangang gumagawa. Kung walang paggawa, walang pagkataya." 17 Sa palagay nina Ferriols at Heidegger, ang pagkatao ng tao ay nakaugat sa kanyang kakayahang tumayong saksi sa meron at mabuhay nang nababatay sa pahiwatig ng meron sa pamamagitan ng malikhaing pag-uulit ng mga katutubong pagbigkas sa meron na hindi maikukulong kailanman sa anumang batayang konspeto. Wika ni Ferriols:

Meron nang pag-iisip na nangyari sa nakaraang panahon, pero ang pag-iisip na nangyari na ay maaaring

\footnotetext{
${ }^{15}$ Ferriols, Pambungad sa Metapisika, 11.

16 Ibid., 128. Ang ellipses ay kay Ferriols.

17Tbid., 119.
} 
pangyarihin muli. Ang mga nangyari sa larangan ng diwa ay hindi natatapos kailanman. At sa taong buhay, hindi naluluma kailanman ang anumang ideya. At kaya nga kung ang isang tao ay makikihalubilo sa isang buhay na pag-iisip, kahit na iyong nag-isip ay namatay na, pero ang kanyang pag-iisip ay buhay pa, kung makikihalubilo ka roon at pangyarihin mo muli, mabubuhay iyon uli sa iyong pag-iisip, at marami kang mauunawaan, marami kang makikita na hindi mo sana makikita kung hindi dahil sa kanya. ${ }^{18}$

Maaaring pangyarihin ang nakaraang pag-iisip sapagkat ito ay nakibahagi sa talagang nangyayari. Ang talagang nangyayari ang pinakabuod at abottanaw ng pangyayari ng kasaysayan kung kaya't ang paglipas ng mga taong kumilala at kumilatis dito ay hindi katumbas ng pagwawakas ng pangyayari nito. Ang meron ay palaging meron, at ang tunay na palaisip ay laging nakakabit sa meron sa pangyayari nito sa kasysayan kung kaya't nagiging makasayasayan ang kanyang mga binigkas na nananawagan lagi ng muli't muling pag-uulit.

Ang pagbigkas sa meron ay pagiging makatotohanan, ang pagpaparaya sa pangyayari ng talagang nangyayari, ang pakikipagsapalaran sa saysay ng kasaysayang patuloy na humihiling ng masigasig na pagpupulis at pagdanas. Hindi sapat ang kumilos lamang sa mundo ng konsepto. Kailangang danasin at bigkasin ang talagang nangyayari sapagkat, "Ang pagbigkas sa meron ay pasiyang mabuhay sa talagang totoo: pasiyang kailangang alagaan at pairalin at iligtas sa mga pag-urong ng kahinaan."19 Bilang paksa ng mga paksa, nananawagan ang meron na patalabin ang bisa ng talagang totoo sa kasaysayan, at mangyayari lamang ito sa pagtalima, pakikinig, pagtataya, at pagbigkas sa meron mismo. Iisa ang sinasabi ng logos: na meron, at ang namimilosopiya ay tinatawag na ulitin ito nang ulitin sa parating bagong paraan sa bawat yugto ng kasaysayan.

\section{Kasaysayan sa Panahong Moderno: Pag-aalala sa Paglimot}

Ayon kay Heidegger, "Withdrawal is an event. In fact, what withdraws may even concern and claim man more essentially than anything present that strikes

${ }^{18}$ Roque J. Ferriols, "Fr. W. Norris Clarke, SJ: Heswitang Metapisiko," in Pagdiriwang sa Meron: A Festival of Thought Celebrating Roque J. Ferriols, SJ, ed. by Nemesio S. Que, SJ, at Agustin Martin Rodriguez (Quezon City: Office of Research and Publications, Ateneo de Manila University, 1997), 268.

${ }^{19}$ Ferriols, Pambungad sa Metapisika, 119.

(c) 2018 Marc Oliver D. Pasco

https://www.kritike.org/journal/issue 23/pasco december2018.pdf

ISSN 1908-7330

(c) $)$ BY-NC-ND 
and touches him." 20 Mula sa pagtanaw na ito, mainam pagmunihan kung anong ispesipikong kaganapan sa kasaysayan ang masasabing kanlungan ng nasabing paglimot. Sa palagay ni Heidegger, sa modernong panahon umabot sa rurok ng paglimot ang tao sa kasaysayan ng Sein. Sa Kartesyanong mundo ng mga bagay na may haba't sukat, pawang ang pagka-nabibilang at pagkanasusukat lamang ng mga nagmemeron ang siyang tinatanglawan ng kasaysayan. Kalkulasyon ang pangunahing patakaran ng pag-iisip at kumikilos ang tao sa daigdig na hubog ng kanyang mismong imahe. Mula sa Arkimedyanong punto na natukoy ni Descartes sa hindi maitatatwang pagiisip ng suheto, sumulong ang kasaysayan tungo sa progresibong pagkakawangis ng lahat ng nagpapakita ayon sa mga plano ng tao para sa kanyang sarili, na siyang naging pundasyon ng modernong teknolohiya. Ang pagkanauuna at pagkapinakatiyak na importante palagi ng cogito bilang fundamentum absolutum inconcussum veritatis ang nagdidikta ng abot-tanaw ng katotohanan ukol sa mga umiiral na nagpapakita. ${ }^{21}$ Ang suheto ang nagtatakada ng mga rasyunal na hangganan kung saan maaari lamang magpakita ang Sein. Ginagawa niya ito sa pamamagitan ng walang humpay na pagbibilang at pagsusukat na naglalayong iuwi sa pagkamasusukat at pagkamabibilang ang lahat sapagkat sa ganitong porma lamang ito kapakipakinabang para sa tao. Ngunit ayon kay Ferriols:

Sa lahat ng pagbilang at pagsukat, may paglayo sa meron na ginaganap. Hindi lamang sa masasalimuot na metodo ng matematika, kundi pati sa pinakasimpleng pagbilang at pagsukat, pati kung nakikita at nahahawakan ng isa isa ang mga binibilang at sinusukat, may paghiwalay sa meron na hindi maiiwasan; sapagkat kailangang tuonan lamang ng pansin ang pagka-maaaring-bilangin at pagka-maaaringsukatin ng mga bagay, at nalilimutan ng taga-sukat ang buong lalim at yaman $n g$ meron. ${ }^{22}$

Sa ganitong konteksto, masasabing nakalilimot ang tao sa misteryong pinagbubukalan ng lahat ng mga umiiral at nakatutok lamang ang kanyang atensyon sa mga aspeto ng umiiral na umaayon sa pagtatakda ng panahong moderno. Kumbaga, hindi sa ayaw ng taong danasin ang mismong meron, sadyang nanakubli lamang ang posibilidad na ito sa kanya dahil siya ay

${ }^{20}$ Martin Heidegger, What is Called Thinking, trans. by J. Glenn Gray (New York: Harper and Row Publishers, 1968), 9.

${ }^{21}$ Martin Heidegger, "The Age of the World Picture," in The Question Concerning Technology and Other Essays, trans. by William Lovitt (New York: Harper and Row Publishers, 1977), 148.

${ }^{22}$ Ferriols, Pambungad sa Metapisika, 170. Kay Ferriols ang italisasyon.

(C) 2018 Marc Oliver D. Pasco

https://www.kritike.org/journal/issue 23/pasco december2018.pdf

ISSN 1908-7330 
nabubuhay sa panahong modernong kung saan paglimot sa meron ang praktikal at usong paraan ng pag-iisip. Masasabing sa yugtong ito ng kasaysayan, ang cogito ang batayang-unibersal ng lahat ng uri ng pagpapakita ng mga umiiral.

Halimbawa, sa panahon ngayon, kapag bumiyahe ang tao patungo sa isang lugar na masasabing hindi pa inaabot ng "pag-unlad," hindi niya maiwasang makita ang mga bakanteng lupa mula sa lente ng paghahati-hati ng mga subdibisyon, o sa upa kada metro kuwadrado ng mga lupang nakatiwangwang na puwedeng tayuan ng mga gusaling pang-komersyo. $\mathrm{O}$ kaya naman, sa mundo ng akademya, bago magsulat ang isang mananaliksik, malay man siya o hindi, ay iniaayon niya ang paksa at metodolohiya ng kanyang sasaliksikin batay sa mga pamantayan ng posibilidad ng pondo para dito, at kung sa palagay niya'y wala naman siyang makukuhang isponsor para sa kanyang paksa ay papalitan niya ito o 'di kaya'y iaangkop ito sa mga kahilingan ng "kapondo-pondong" pananaliksik.

Sa madaling salita, sa ating modernong panahon, isinusulong ng iba't ibang sangay ng kaalamang maka-agham at teknolohikal ang isang uring pagtanaw na nagkakahon sa mga nagmemeron sa kuwadro ng pagkamaaaring-masukat at pagka-maaaring-mabilang sa layong isalin sa wika ng kalkulasyon ang logos ng meron. Pagkatiyak sa sariling mga ideya ang layunin ng ganitong pag-iisip at hindi ang pakikinig sa meron. Ang subiectum, ang yaong nauuna't nakalatag na bago pa ang lahat, ang basehan ng pagiging umiiral ng mga umiiral. Ito ang panahon ng paglimot sa meronang walang-malay na pananalamin ng suheto sa kanyang sarili sa lahat ng kanyang nakikita kung saan may mabalintunang alyenasyon ang nagaganap sa relasyon niya sa meron mismo. Dagdag pa ni Heidegger, "What is, in its entirety, is now taken in such a way that it first is in being and only is in being to the extent that it is set up by man, who represents and sets forth." ${ }^{23}$ Ang mismong pagmemeron, ang pagka-talaga ng nangyayari ay itinatalaga ng iba't ibang kilos-representasyon ng cogito sa sarili nito. Ang pangyayari ng nangyayari at ang kasaysayan ng pangyayari ng mga ito na naunawaan ng mga sinaunang Griyego bilang galaw mismo ng meron (bilang phusis, techné at alêtheia) na humihiling ng pagsabay at pakikibagay ay nalilimot at nauuwi sa mga kalkuladong numero at datos na handang magamit ng tao sa anumang paraan at panahon (Bestand). Ang nakakubling esensya ng Sein bilang pagprepresensya ng mga nagprepresensya ay nalilimot bilang siyang lihim na abot-tanaw ng saysay ng kasaysayan.

Sa bahagi ng kanyang libro kung saan pinag-usapan niya ang sozein ta phainomena ng penomenolohiya, nililinaw ni Ferriols na ang pagliligtas sa nagpapamasid ay hindi lamang ukol sa mga bagay na nagpapakita sa

${ }^{23}$ Heidegger, "The Age of the World Picture," 129-130.

(c) 2018 Marc Oliver D. Pasco

https://www.kritike.org/journal/issue 23/pasco december2018.pdf

ISSN 1908-7330

(c) $)$ BY-NC-ND 
kasalukuyan, kundi nangangailangan din ng pagtalima sa mga hindi pa nagpapakita o hindi pa napagmamasdan. Tunay na makasaysayan ang pagunawa ni Ferriols sa phainomena-nagpapasilip ito hindi lamang bilang nandiyan na o nandiyan na dati, kundi bilang hindi pa nagpapamasid, yaong hindi pa hinog sa panahon para mapansin at maisalba. Wika niya, "Bahagi rin ng sozein ta phainomena na hanapin at antabayanan at magpaka-alisto sa mga hindi pa napagmamasdan. Nasa sozein ta phainomena din ang pagkabukas ng loob sa data na darating pa." ${ }^{24}$ Kumikilos sa isang makasaysayang abot-tanaw ang puntong ito ni Ferriols. Bahagi ng pagpapakita ng nagpapakita ang pagiging dinamiko nito. Kung layon ng kalkulatibong pagiisip ng modernong panahon ang pagpapako sa ngayon ng kasaysayan, sa ganang ang ngayon ang laging handang mabilang, makalkula, at mapanghawakan, iminumungkahi ni Ferriols at ni Heidegger ang walang sawang pag-aantabay sa wala pa at sa hindi pa nagpapakita. Kailangang isalba ang mga posibilidad ng meron na natatabunan ng pagka-obheto nito sa harap ng suheto. Nananawagan ang pag-iisip na mamulat ito sa sarili nitong mga hangganan sa abot-tanaw ng meron. Kaya't nasabi ni Heidegger na, "Most thought-provoking in our time is that we are still not thinking.... that we are still not thinking stems from the fact that the thing itself that must be thought about turns away from man, has turned away long ago." ${ }^{25}$ Sinasabi ni Heidegger na tayo ay nabubuhay sa isang panahon kung saan napakahirap umusbong ang tunay na pag-iisip, hindi dahil hindi tayo nag-iisip, kung hindi dahil sadyang nagtatago ang dapat na pinag-uukulan ng ating pag-iisip at pagtalima.

Ano pa nga ba itong nagtatagong sadyang lampas sa abot-tanaw ng kasalukuyang uri ng pag-iisip kung hindi ang misteryosong pagtatakda ng Sein ng mismong paglimot na nangyayari sa yugtong ito ng kasaysayan. Sinususugan ng pag-iisip ni Heidegger ang punto ni Ferriols ukol sa pagbubukas-loob sa hindi pa nagpapakita. Wika niya, "The more original the thinking, the richer will be what is unthought in it. The unthought is the greatest gift that thinking can bestow." 26 Habang mas naiuugat ng nag-iisip ang sarili niya sa hindi-maiisip-at-hindi-pa-mabibigkas-na-nabigkas-na-rin-dati, mas nagiging mulat siya sa kanyang pagiging kabahagi ng kasaysayan ng talagang nangyayari. At ano ba ang talagang nangyayari ngayon, at mula pa noon-ang meron, at parating meron, maging sa panahon ng animo'y pagwawala ng tao sa kasaysayan. Kailangang ulitin ang pag-aalala sa paglimot ng kalimot-limot na talagang nangyayari sa kasaysayan sa pamamagitan ng tunay na pag-iisip, o sa wika ni Ferriols, sa pagbigkas sa meron. Sapagkat, wika nga ni Heidegger, "In order to bring into view what

${ }^{24}$ Ferriols, Pambungad sa Metapisika, 187.

${ }^{25}$ Heidegger, What is Called Thinking, 6-7.

${ }^{26}$ Ibid., 76.

(C) 2018 Marc Oliver D. Pasco https://www.kritike.org/journal/issue 23/pasco december2018.pdf ISSN 1908-7330 


\section{FERRIOLS AT HEIDEGGER}

resides in a visual field, the visual field must precisely light up first, so that it might illuminate what resides within it; however, it cannot and may not be seen explicitly. The field of view, alêtheia, must in a certain sense be overlooked." 27 Sa ganitong pagtanaw, ang kasaysayan ng paglimot ay hindi lamang nakaugat sa modernong kalkulatibong pag-iisip kung hindi sa mismong esensya ng katotohanang patuloy na nagkukubli sa kasaysayan. Dagdag pa ni Heidegger, "To recollectively think-upon what has-been is to fore-think into the unthought that is to be thought. To think is to recollectively fore-think. It neither dwells on what has-been as a past represented by historiography, nor is it a representational thinking that stares with prophetical pretenses into a supposedly known future. Thinking as a recollective fore-thinking is the leaping of the leap. This leap [Sprung] is a movement [Satz] to which thinking submits." 28 Nangangailangan ng isang paglundag patungo sa pag-aalala sa hindi pa nasasabi ang pakikipagsapalaran ng tao sa kasaysayan ng talagang nangyayari. Gaya ng sinabi ni Ferriols, kailangang isalba ang hindi pa rin nabibigkas, bilang sarili nito-bilang siyang hindi pa rin nabibigkas na dapat bigkasin. Ang paglundag na ito ay isang radikal na pag-aalala sa isang katotohanang hindi pa lantad sa tao sa modernong panahon, at kung gayo'y humihiling ng matinding pasensya at atensyon mula sa mga taong umaasang mabigkas ang totoo.

\section{Pangwakas}

Ang kasaysayan ng meron ay nangyayari lamang sa pag-aalala sa paglimot. Iiisa ang paksa ng lahat ng pagbigkas-ang meron, subalit kailangang maging mulat sa katotohanang sa bawat pagtatangkang bumaling sa totoo at maging makabuluhang bahagi ng kasaysayan, nandoon lagi ang hindi maiiwasang posibilidad ng paglimot dahil na rin sa mismong esensya ng meron. Bago pa man subuking bigkasin ang ipinahihiwatig ng meron sa kasaysayan, kailangan munang magpadala ang tao sa tawag ng meron na magpapamulat sa kanya na madalas kaysa hindi, walang masasabi sa harap ng kayamanan ng meron. Kailangang hayaang maging daluyan ng wika ng meron ang wika ng tao kung nais niyang bumigkas ng totoo. Sa wika ni Ferriols, "May pagbigkas ng salita na kusang pag-apaw ng biglang liwanag; nagiging sabay bunga at sanhi ng pag-uunawa ang ganiyang salita. May pagbigkas ng salita na pagtupad ng tao sa kanyang papel sa daigdig bilang taga-unawa at pag-uunawa. Ang ganyang pagbigkas ay hindi lamang nanggagaling sa tao bilang sangkap ng sansinukob, kundi isang kilos din ng

\footnotetext{
${ }^{27}$ Heidegger, Basic Questions of Philosophy: Selected "Problems" of "Logic," trans. by Richard Rojcewicz and André Schuwer (Indianapolis: Indiana University Press, 1994), 127-128.

${ }^{28}$ Heidegger, The Principle of Reason, 94.

(c) 2018 Marc Oliver D. Pasco

https://www.kritike.org/journal/issue 23/pasco december2018.pdf

ISSN 1908-7330
}

(cc) BY-NC-ND 
sansinukob na tumatalab sa loob ng tao." ${ }^{29}$ Hindi lamang isang instrumento ang salita na ginagamit ng tao para ipahayag ang kanyang saloobin. Hindi rin ito simpleng konsepto na kumakahon at nagbibigay-hugis at mukha sa mga umiiral para sa tao. "Language is the lighting-concealing arrival of being itself." 30 Sa wika nagaganap ang mismong pangyayari ng meron. Sa wika nasasangkot ang tao sa kasaysayan ng talagang nangyayari. Sa wika bumabakas ang kasaysayan. Kaya't kailangang ulit-ulitin ang pagbigkas, sapagkat hanggang meron, hanggang may nangyayari, patuloy ang pagkukubli ng meron sa kanyang kapayakan. Ang kasaysayan ng talagang nangyayari ay kailangang patuloy na danasin ng taong nakatadhanang makalimot sa kanyang lugar sa kasaysayan. Tunay na makasaysayan ang mga ginanap na pamimilosopiya nina Ferriols at Heidegger. Pareho nilang sinubukang buksan ang sarili sa paanyaya ng pakikipagsapalaran sa pangyayari ng talagang nangyayari. Hindi maluluma ang kanilang pamimillosopiya sapagkat ito ay nangyayari pa rin at mangyayari pa, hangga't may mga katulad nating naghahangad na masabi ang hindi masasabi.

Department of Philosophy, Ateneo de Manila University, Philippines

\section{References}

Ferriols, Roque, Mga Sinaunang Griyego (Quezon City: Office of Research and Publications, Ateneo de Manila University, 1991). . Pambungad sa Metapisika (Quezon City: Office of Research and Publications, Ateneo de Manila University, 1997). . "Fr. W. Norris Clarke, SJ: Heswitang Metapisiko," in Pagdiriwang sa Meron: A Festival of Thought Celebrating Roque J. Ferriols, SJ, ed. by Nemesio S. Que at Agustin Martin Rodriguez (Quezon City: Office of Research and Publications, Ateneo de Manila University, 1997).

Heidegger, Martin, An Introduction to Metaphysics, trans. by Ralph Manheim (New York: Yale University Press, 1959). . What is Called Thinking, trans. by J. Glenn Gray (New York: Harper and Row Publishers, 1968). . "A Dialogue on Language," in On the Way to Language, trans. by. Peter D. Hertz (New York: Harper and Row Publishers, 1971). . "The Anaximander Fragment," in Early Greek Thinking, trans. by David Farrell Krell at Frank A. Capuzzi (San Francisco: Harper San Francisco, 1975).

${ }^{29}$ Ferriols, Mga Sinaunang Griyego, 21.

${ }^{30}$ Heidegger, "Letter on Humanism," trans. by Frank A. Capuzzi, in Pathmarks, ed. by William McNeill (Cambridge. Cambridge University Rress, 1998), 249.

(c) 2018 Marc Oliver D. Pasco https://www.kritike.org/journal/issue 23/pasco december2018.pdf ISSN 1908-7330 


\section{FERRIOLS AT HEIDEGGER}

. "The Age of the World Picture," in The Question Concerning Technology and Other Essays, trans. by William Lovitt (New York: Harper and Row Publishers, 1977).

. "The Turning," in The Question Concerning Technology and Other Essays, trans. by William Lovitt (New York: Harper and Row Publishers, 1977).

. Basic Concepts, trans. by Gary E. Aylesworth (Indianapolis: Indiana University Press, 1993).

. Basic Questions of Philosophy: Selected "Problems" of "Logic," trans.

by Richard Rojcewicz and André Schuwer (Indianapolis: Indiana University Press, 1994).

. The Principle of Reason, trans. by Reginald Lilly (Indianapolis: Indiana University Press, 1996).

. "Letter on Humanism," trans. by Frank A. Capuzzi, om Pathmarks, ed. by William McNeill (Cambridge: Cambridge University Press, 1998).

Inwood, Michael, A Heidegger Dictionary (Malden: Blackwell Publishers, 1999).

Seidel, George, Joseph, Martin Heidegger and the Pre-Socratics (Nebraska: University of Nebraska Press, 1964). 


\title{
Ilang Katagang Filipino bilang Bukal ng Pamimilosopiya
}

\section{Noel L. Clemente}

\begin{abstract}
Despite Roque J. Ferriols's initiative of teaching philosophy in the Filipino vernacular, many philosophy teachers in the Philippines still use primarily European thinkers, albeit translating their ideas into Filipino. Emerita S. Quito questions the suitability of the Filipino language for philosophizing: can we philosophize in Filipino without merely translating Western ideas? In this paper, I want to dispel Quito's doubts by examining Filipino words that are rich in philosophical meaning, which, I argue, are not merely translations of European ideas. I focus my discussion on key terms in teaching Philosophy of the Human Person: how 'pagninilay' describes what philosophizing is, how 'pagkakataon' captures the historicity of the human person, and how 'tao po' illustrates what philosophy of the human person is about, within a particularly Filipino experience. Through these Filipino terms, I hope to show that our language is indeed rich in philosophical insight.
\end{abstract}

Keywords: philosophizing in Filipino, pagninilay, pagkakataon, philosophy of the human person

\section{Pambungad}

K

araniwang mga Kanluraning pilosopo at teksto ang ginagamit sa pagtuturo ng pilosopiya sa Filipinas-Socrates, Plato, Rene

Heidegger, Gabriel Marcel, at marami pang iba. Hindi naman ito nakagugulat sapagkat ang Europa ang isa sa pinakamatanda at pinakamatatag na kanlungan ng pilosopiya sa mundo. Dahil dito, palasak din ang paggamit ng Ingles bilang wika sa pag-aaral ng pilosopiya-pati na rin ng ibang asignatura - sa mga silid-aralan. Napuna ni Roque J. Ferriols ang kabalintunaan ng ganitong kalakaran: bukod sa pagpapabása sa mga magaaral ng mga artikulong nása banyagang wika, pinag-iisip din sila sa isang

(C) 2018 Noel L. Clemente

https://www.kritike.org/journal/issue 23/clemente december2018.pdf

ISSN 1908-7330

$(c c)$ BY-NC-ND 


\section{ILANG KATAGANG FILIPINO}

wikang hindi kinasanayan ng kanilang diwa. ${ }^{1}$ Ito ang nagtulak sa kaniyang isulong ang pagtuturo ng pilosopiya sa wikang Filipino noong $1969 .{ }^{2}$

Sa pambungad sa isang Festschrift para kay Ferriols, inilalagom nina Nemesio Que at Agustin Rodriguez ang kahalagahan ng pagtuturo ng pilosopiya at pag-iisip sa katutubong wika:

Kung magtuturo ka ng buháy na pag-iisip sa mga magaaral, kailangan silang mapag-isip sa kanilang buháy na wika. Ibig sabihin, hindi ang wikang pormal na hitik sa naisaulong pormula, kundi ang wikang ginagamit nila sa pagdanas ng katalagahan at pamumuhay sa kanilang mundo. Samakatwid, may pangangailangang mamilosopiya sa wikang Filipino. ${ }^{3}$

Nagpapatúloy ang ganitong tradisyon ng pamimilosopiya ${ }^{4}$ at pagtuturo ng pilosopiya sa wikang Filipino ${ }^{5}$ na pinasiklab ni Ferriols. Ngunit dahil na rin sa kasanayan ng mga Filipino sa pilosopiyang Europeo, hindi maiiwasan ang paghahambing ng pamimilosopiya ni Ferriols sa mga ideya ng mga Europeo. Halimbawa, may mga kumukuwestiyon kung ang meron $^{6}$ ba na tinatalakay

\footnotetext{
${ }^{1}$ Nemesio S. Que and Agustin Martin G. Rodriguez, eds., Introduction to Pagdiriwang sa Meron: A Festival of Thinking Celebrating Fr. Roque J. Ferriols, S.J. (Quezon City: Ateneo de Manila University, 1997), vi.

${ }^{2}$ Para sa kasaysayan at konteksto ng pagpapasiya ni Ferriols na magturo ng pilosopiya sa Filipino, tingnan ang Franz Giuseppe F. Cortez, "The Linguistic Turn as a Political Act: Another Look at the Thoughts of Roque Ferriols," Kritike: An Online Journal of Philosophy, 8:1 (June 2014), 51-55, pati na rin ang kinalap ni Glenda C. Oris na panayam sa "Ferriols on Ferriols and More," Perspectives in the Arts and Humanities Asia 5:1 (2015), 121-125.

${ }^{3}$ Salin ng may-akda sa "If one were to teach living thought to students, they need to be made to speak in their living language. That is to say not the formal language of memorized formulas and petrified discourse, but the language with which they experience their world and live their reality. Thus, the necessity to allow philosophy to speak in Filipino," mula sa Rodriguez and Que, Introduction, vii.

${ }^{4}$ Nananatiling bukal ng pananaliksik ang pilosopiya ng "meron" ni Ferriols, pati na rin ang kaniyang pamamaraan ng pamimilosopiya sa katutubong wika. Ilan sa mga kontemporanyong artikulo ang mga sumusunod: Roy Allan B. Tolentino, "Biyaya ang Meron, Biyaya ng Meron: Ang Pag-iisip nina Ferriols, Marion, at San Agustin," Perspectives in the Arts and Humanities Asia 5:1 (2015), 91-107; Albert M. Lagliva, "Ang Paraan at mga Elemento ng Pagtuturo ni Roque J. Ferriols, SJ, tungo sa Matinong Pag-Uunawa," Perspectives in the Arts and Humanities Asia 5:1 (2015), 41-53; at Wilhelm P.J. Strebel, "Pitong Sulyap sa Pilosopiya ng Wika ni Ferriols," Kritike: An Online Journal of Philosophy, 12:1 (June 2018), 39-55.

${ }^{5}$ Sa kasalukuyan, halos kalahati ng mga kurso sa pilosopiya sa Pamantasang Ateneo de Manila ay itinuturo sa wikang Filipino. Ilan sa kanila sina Remmon E. Barbaza, Eduardo Jose E. Calasanz, Preciosa A. De Joya, Albert M. Lagliva, Michael Ner E. Mariano, Mark Oliver G. Pasco, Jovino G. Miroy, Agustin Martin G. Rodriguez, Wilhelm P.J. Strebel, at Venusto F. Suarez.

${ }^{6}$ Matatagpuan ang ekstensibong pamimilosopiya ni Ferriols ukol sa meron sa kaniyang Pambungad sa Metapisika (Quezon City: Ateneo de Manila University Press, 2014).
}

(C) 2018 Noel L. Clemente

https://www.kritike.org/journal/issue 23/clemente december2018.pdf

ISSN 1908-7330

(c) BY-NC-ND 
ni Ferriols ay katulad ng Sein ni Heidegger. ${ }^{7}$ Lumilitaw rito ang suliranin ng potensiyal ng wikang Filipino sa pilosopiya: káya ba nating gamitin ang sariling wika sa pamimilosopiya nang hindi lámang isinasalin ang mga ideya ng Europeo?

Sa palagay ni Emerita S. Quito, hindi. Isa sa mga dahilan kung bakit naniniwala siyang walang maituturing na pilosopiyang Filipino ${ }^{8}$ ay dahil hindi kondusente ang wikang Filipino sa pagtalakay ng mga abstraktong paksa ng pilosopiya. Isinusulat niya: "Maging ang wika natin ay hindi bagay sa pilosopiya. Walang katumbas sa Filipino ang mga salitâng being, essence, existence, becoming, actuality, transcendence." ${ }^{9}$

Tinatawag ito ni Albert E. Alejo na isa sa mga "tiyanak ng kalooban," mga mapanuksong elemento na sinusubok linlangin at iligaw ang mga manlalakbay sa pag-iisip. ${ }^{10}$ Dahil sa ganitong pangamba sa kakayahan ng sariling wikang maipahayag ang mga pilosopikong dalumat, may mga nagaalinlangan na gamitin ang Filipino sa pamimilosopiya. Ang kadalasang paratang: Filipino man ang wikang ginagamit, mga Europeong ideya pa rin ang pinag-iisipan, at isinasalin lámang ang mga ito sa ating wika. At kung hindi man mahanapan ng katumbas na salita sa Filipino, ninanakaw na lang ang mga salitang pilosopiko: Angst, Sein, differánce, atbp.

Sa papel na ito, nais kong tuligsain ang haka ni Quito; gusto kong ipakita na may pangako ang wikang Filipino para sa pamimilosopiya sa kabila ng mga di maisasaling kataga. ${ }^{11}$ Ani Ferriols, "may natatanging potensiyal ang bawat

7 Halimbawa, para kay Leonardo Mercado, ang ideya ng "meron" ni Ferriols ay maisasalin bilang "being." Taliwas dito, iginigiit ni Mark Joseph Calano na hindi ito salin ng being ng Ingles, Sein ng Aleman, être ng Pranses. Ayon sa kaniyang panayam kay Ferriols, ni hindi pa nabasa nitong hulí ang Being and Time ni Martin Heidegger. Tingnan ang Mark Joseph Calano, "Ang Pilosopiya at si Roque J. Ferriols, SJ," Perspectives in the Arts and the Humanities 5:1 (2015), 15.

${ }^{8}$ Isang kontrobersiyal na paksa noong dekada sitenta ang suliranin ng kung mayroon bang matatawag na "pilosopiyang Filipino," na tinatalakay pa rin hanggang ngayon. Bagaman interesante ang usaping ito, nalilihis na ito sa paksa ng papel ko. Maaaring tingnan ang iba't ibang pananaw sa Roque J. Ferriols, "A Memoir of Six Years," Philippine Studies 22 (1974), 339340, Leonardo N. Mercado, Elements of Filipino Philosophy (Tacloban City: Divine Word University Publications, 1993), 3-4; at Emerita S. Quito, Lectures on Comparative Philosophy (Manila: De La Salle University Press, 1979), 22-29.

${ }^{9}$ Salin ng may-akda sa "Even our langauge does not lend itself to philosophy. There are no equivalents to words like being, essence, existence, becoming, actuality, transcendence," mula sa Quito, Lectures on Comparative Philosophy, 29.

${ }^{10}$ Albert E. Alejo, Tao pô! Tulóy! Isang Landas ng Pag-unawa sa Loob ng Tao (Quezon City: Ateneo de Manila University Office of Research and Publications, 1990), 6.

${ }^{11}$ Hindi ko nais ipahiwatig dito na sinasalungat ni Quito ang proyekto ng paggamit ng wikang Filipino sa pamimilosopiya. Sa katunayan, iginigiit niya ang kahalagahan ng paggamit ng ating wika sa iba't ibang larang, kasama na ang pilosopiya, upang mapaunlad ang wika, sa "Ang Kayamanan ng Wikang Filipino," in A Life of Philosophy: Festschrift in Honor of Emerita S. Quito (Manila: De La Salle University Press, 1990), 604-605. Nais kong bigyang-diin na ang tinutuligsa ko rito ay hindi ang hamak na posibilidad ng pamimilosopiya sa wikang Filipino, 


\section{ILANG KATAGANG FILIPINO}

wika sa pagtingin at pagdama,"12 at dahil dito, may nabibigkas ang ating wika na marahil hindi maaaring bigkasin sa Ingles, Pranses, Aleman, o iba pang wika (katulad din ng alegasyon na hindi mabibigkas sa Filipino ang being, transcendence, etc. na pinag-usapan ng mga Europeo). Ipapakita ko, gamit ang tatlong halimbawa ng mga katagang Filipino, na naglalaman ang ating wika ng mga karanasang bukal ng pilosopikong pagninilay.

Igigiit kong ang mga katagang Filipino na tatalakayin ko sa papel na ito, taliwas sa pangamba ni Quito, ay hindi hamak na pagtatangkang (o pagpipílit) isalin ang mga ideyang Europeo sa sarili nating salita. Hindi ko naman inimbento ang mga katagang ito, maging ang kanilang mga kahulugan; karaniwan nang ginagamit ang mga salitang ito bagaman hindi namamalayan ang kanilang pilosopikong pahiwatig. Sapagkat "taal na paraan ng pamumuhay ang bawat wika," 13 may nilalaman ang mga katagang ito na nagkataon lámang na kahawig - ngunit hindi ganap na katumbas-ng mga pilosopikong ideya ng Europa. Sa katunayan, walang monopolyo ang alinmang wika sa pamimilosopiya; nauna mang mailimbag sa Pranses o sa Aleman ang mga ideya ng mga pilosopong Europeo, hindi ito nangangahulugang walang ganoong katotohanan sa ating wika

Samakatuwid, nais kong ipakita sa papel na ito na nararanasan din nating mga Filipino, sa pamamagitan ng ating wika, ang mga katotohanang naipahayag na sa ibang wika. Kung tutuusin, sinusubukan naman ng pilosopiyang pag-usapan ang mga unibersal na karanasan ng tao sa mundo, ngunit matutunghayan natin sa ating wika ang pagka-partikular nito sa ating danas. Babanggitin ko ang mga ideya ng mga Europeong pilosopo dahil ito marahil ang mas kilalá ng mambabasa (lalo na sa mga nag-aaral ng pilosopiya), ngunit hindi ito nangangahulugan na hinango ko ang kahulugan ng mga katagang Filipino sa mga pilosopong Europeo. ${ }^{14}$ Muli, bagaman may pagkakahawig, hindi sila ganap na magkatumbas.

Hindi sasapat ang maikling papel na ito (o maging isang buong aklat) para suriin ang lahat ng mga salitang may taglay na malalim na pilosopikong danas. Kayâ pagtutuunan ko ng pansin ang tatlong kataga na sa tingin ko'y

kundi ang paggamit ng ating wika nang hindi basta isinasalin ang mga pilosopiya ng mga Europeo.

12 Salin ng may-akda sa "Each language has unrepeatable potentials for seeing and feeling," mula sa Ferriols, "A Memoir of Six Years," 340.

${ }^{13}$ Salin ng may-akda sa "Each language is a way of being alive that is irreducible," mula sa ibid., 340 .

${ }^{14}$ Kahawig ito ng estratehiya ni Leonardo Mercado sa pagtatangkang makausap ang mga mambabasang mas nasanay sa pag-aaral ng pilosopiyang Kanluranin. Ipinapaliwanag niya na itinatapat lang niya ang nililinang niyang pilosopiyang Filipino sa mga kaisipang Kanluranin para mas maunawaan ng mga mambabasa ang kaniyang ipinapaliwanag, ngunit iginigiit niya na hindi ito pagmamaliit sa mga kaisipang Filipino. Tingnan ang Mercado, Elements of Filipino Philosophy, 13.

(C) 2018 Noel L. Clemente

https://www.kritike.org/journal/issue 23/clemente december2018.pdf

ISSN 1908-7330

(cc) BY-NC-ND 
akmang inilalahad ang mga sentral na ideya ng Pilosopiya ng Tao: una, kung ano ang pilosopiya; ikalawa, kung ano ang tao; at ikatlo, kung ano ang pamimilosopiya ukol sa tao. Titingnan ko sa mga susunod na bahagi ang pilosopiya bílang isang pagninilay, ang táong sumasakasaysayan bílang pagkakataon, at ang pamimilosopiya ukol sa tao bílang Tao po! Sa pamamagitan ng tatlong halimbawang ito, umaasa akong mamumulat ang mambabasa sa pagkabukal ng wikang Filipino sa pamimilosopiya.

\section{Pamimilosopiya bilang Pagninilay}

Karaniwang ginagamit ang kurso ng Pilosopiya ng Tao bílang pambungad sa pilosopiya. ${ }^{15}$ Dahil dito, isa sa mga pinakamahahalagang maunawaan ay kung ano nga ba ang pilosopiya, at kung paano ito naiba sa ibang uri ng pag-iisip. Iginigiit ni Ferriols na "Lalong mabuting gawin muna bago pag-usapan kung ano [ang pilosopiya]. Sapagkat ang pilosopiya ay ginagawa."16 Inihahambing niya ang pamimilosopiya sa paglalakad, pamimisikleta, paglalangoy, at pagmamaneho: mga gawaing natututuhan ng tao sa mismong paggawa nito. Sa kabila nito, hindi maiiwasan ng táong maghanap ng mapanghahawakang paunang ideya o konsepto ng kung ano ang pilosopiya. Maaari itong mabasag at maitama kalaunan, gayunpaman likás sa tao na magsimula sa isang konsepto sa pagkatuto.

Kaugnay nito, kadalasang ikinakabit ang ideya ng pagninilay o pagmumuni sa pamimilosopiya. Itinuturing ng mga tao na mapagnilay ang pilosopiya. Ngunit tulad ng pagpapaliwanag ni Gabriel Marcel, kadalasan namang iniuugnay ang pagninilay sa isang 'malalim' na gawain, na tíla ba kailangan mong magkulong sa iyong silid at lumayo sa ibang tao upang makapagnilay nang maayos. ${ }^{17}$ Sa gayon, tinitingnan ang mga pilosopo, o sinumang palánilay, bílang mga "malalalim" na tao na para bang lutáng sa mundo. Nariyan ang kuwento ng sinaunang pilosopong Griyego na si Thales na naglalakad nang nakatingala sa mga bituin at sapagkat hindi nakatingin sa dinaraanan ay nahulog sa balon. Makikita rin ang ganitong karikatura ng mga pilosopo sa sining at panitikan: nariyan si Pilosopo Tasyo ng Noli Me Tangere na inilalarawan bílang may sariling mundo at hindi gaanong

15 Sa kasalukuyang "core curriculum" (mga asignaturang inaaral ng lahat ng estudyante, anuman ang kanilang major) ng kolehiyo sa Pamantasang Ateneo de Manila, ang Pilosopiya ng Tao ang unang kurso sa pilosopiya ng mga mag-aaral. Dahil dito, ang unang paksa sa kursong ito ay pagtatanong sa kung ano nga ba ang pilosopiya.

${ }^{16}$ Ferriols, Pambungad sa Metapisika, ix.

17 Ipinapaliwanag ni Gabriel Marcel sa unang bahagi ng ikalimang kabanata ng kaniyang aklat ang ganitong karaniwang palagay ukol sa pagninilay, at pinapabulaanan niya ito sa pagpapakitang nakaugat ang pagninilay sa búhay. Tingnan ang Gabriel Marcel, Reflection and Mystery, vol. 1 of The Mystery of Being, trans. by G.S. Fraser (London The Harvill Press, 1951), $77-$ 82. Mula rito, tutukuyin ang akda bilang The Mystery of Being.

(c) 2018 Noel L. Clemente

https://www.kritike.org/journal/issue 23/clemente december2018.pdf

ISSN 1908-7330

(cc) BY-NC-ND 


\section{ILANG KATAGANG FILIPINO}

kinakausap ng mga tao, pati na rin ang eskultura ni Auguste Rodin na The Thinker na nagpapakitang ang isang palaisip ay karaniwang mag-isa.

Taliwas sa karaniwang konsepto patungkol sa pilosopiya, may sinasabi ang mismong salitang pagninilay ukol sa kung ano ba talaga ang pamimilosopiya. Maaaring ituring na salitang ugat nito ang silay, ${ }^{18}$ na nangangahulugang pagtingin. Samakatuwid, bago pa man tayo sumisid sa kalaliman ng ating loob, ang pagninilay ay isa munang pagtingin. Ipinapakita ni Marcel sa karanasan ng pagkawala ng kaniyang relo na ang pagninilay ay nagsisimula sa pagbibigay-pansin sa mga bagay na mahalaga sa isang tao. ${ }^{19}$ Pamilyar ang ganitong karanasan: kapag nawawalan ako ng relo, o cellphone, pitaka, susi, o anumang bagay na hindi ko matagpuan sa karaniwang kinalalagyan, aalalahanin ko kung saan ko ito hulíng nakita, hahalughugin ang mga lugar na pinanggalingan ko, hanggang sa matagpuan ko ang nawawala. Nagsisimula ang pagtingin sa ganitong mga bitak sa karanasan: may nawawala, may bago, may kakaiba, may hindi ako napansin dati kayâ nagtataka ako ngayong napansin ko na. Ayon sa mga sinaunang Griyego, ito ang thaumazein o wonder na sinasabing simula ng pamimlosopiya; nagaganap lamang ang pagtataka at pagkamangha kung tumingin muna ako. ${ }^{20}$ Ito rin ang hámon ni Wittgenstein: "Look and see!" para matuklasan kung paano gumagana ang wika. ${ }^{21}$

Ganito rin ang ipinahihiwatig ng salita ng mga sinaunang Griyego sa katotohanan. Para sa kanila ang katotohanan ay aletheia: pagkakawala sa pagkakakubli, samakatuwid, pagpapakita. ${ }^{22}$ Masasaksihan lamang ng isang tao ang nagpapakita kung sisilayan niya ito. Kung hindi matalas ang kaniyang pagtingin, ang kaniyang pagsilay, hindi niya makikita ang nagpapakita. Sang-ayon ito sa isa pang karaniwang konsepto ng pilosopiya bilang paghahanap ng katotohanan: masisimulan ko lang mahanap ang katotohanang nagpapakita (aletheia) kung titingnan ko ito (pagninilay at pamimilosopiya).

Dagdag pa rito, ipinapaliwanag ni Ferriols na kung nais mong makita, kailangang 'ikaw' ang tumingin. ${ }^{23}$ Walang ibang puwedeng

18 Ayon sa UP Diksiyonaryong Filipino, binagong ed., s.v. "nilay", "nilay" ang tinukoy na salitang ugat ng "pagninilay." Ang iminumungkahi kong pag-uugnay ng "nilay" sa "silay" ay sarili kong interpretasyon, na inaasahan kong maaaring pagmulan ng hinuhang pilosopiko.

${ }^{19}$ Marcel, The Mystery of Being, 77-78.

${ }^{20}$ Aristotle, Metaphysics, trans. by W.D. Ross, in The Basic Works of Aristotle, ed. by Richard McKeon. (New York: Random House, 1941), 982b 11-24.

${ }^{21}$ Ludwig Wittgenstein, Philosophical Investigations, rev. 4th ed., ed. by P.M.S. Hacker and Joachim Schulte, trans. by G.E.M. Anscombe, P.M.S. Hacker, and Joachim Schulte (Malden: Wiley-Blackwell, 2009), §§ 66, 72, 93, 578.

22 Pansinin na sinasalamin ng salitang aletheia ang karansan ng mga sinaunang Griyego sa pamimilosopiya, sa parehas na paraan na ipinakikita kong nakikita sa pagninilay o pagsilay ang karanasan ng Filipino sa pamimilosopiya.

${ }^{23}$ Ferriols, Pambungad sa Metapisika, xi-xii.

(c) 2018 Noel L. Clemente

https://www.kritike.org/journal/issue 23/clemente december2018.pdf

ISSN 1908-7330

(cc) BY-NC-ND 
tumingin para sa iyo; maaaring ikuwento ng ibang tao ang nakita nila sa iyo, ngunit kung mananatili ka lang sa pakikinig ng kanilang kuwento, wala kang makikita. Samakatuwid, lubos na personal ang karanasan ng pagtingin. Ang aking pagtingin ay maaaring hindi katulad ng pagtingin ng ibang tao, bagaman magkaparehas kami ng bagay na tinitingnan. Lumilitaw rito ang iginuhit ni Marcel na pagkakaiba ng pagmumuning primarya at sekundarya. ${ }^{24}$ Paliwanag niya, ang pagmumuning primarya ay isang obhetibong pagtanaw sa bagay; nagmumula ang 'obheto' sa ob-jectum na nangangahulugang "pagtatapon sa harap." Samakatuwid inilalagay ko sa harap ko ang bagay na pinagmumunihan, na tíla isang bagay na hiwalay sa akin. Dahil hiwalay ito sa akin, maaari ko itong suriin, kalikutin, at kumpunihin, upang maunawaan nang maayos. Mahalaga rito ang pagkakahiwalay ng nagninilay sa pinagninilayan; may agwat na tumutulot sa pagsusuri. Karaniwang itinuturing na obhetibo ang mga agham at matematika sapagkat nararapat na may paghihiwalay ang mga siyentista at matematiko sa kanilang inaaral. Ang mga suliraning ganito ay maaaring sagutin at pag-isipan ninuman, at inaasahan na magkatulad lamang ang mga sagot na makukuha, sapagkat hindi naman nakasalalay ang suliranin sa umuunawa nito.

Sa kabilâng banda, ang pagmumuning sekundarya naman ay suhetibo; ang 'suheto' ay mula naman sa sub-jectum bilang "pagtatapon sa ilalim." Hindi ganoon kadaling ihiwalay ang nagninilay sa pinagninilayan, dahil bahagi ng pagninilay ang nagninilay. Halimbawa, ang mga opinyon ay inilalarawan bilang suhetibo sapagkat hindi maihihiwalay ang mga ito sa taong pinanggalingan nito; ang magkakaibang tao ay may magkakaibang opinion. Sangkot siya sa mismong pagtingin, at hindi lamang hamak na tagamasid. Ganito ang nais ipahiwatig ni Ferriols sa kaniyang sikát na paanyaya: "Lundagin mo beybe!" 25 Kailangan mong tumingin kung nais mong ikaw ang makakita. Bagaman maaaring pag-aralan ang pilosopiya bilang isang obheto sa pamamagitan ng pagbabasa at pag-uunawa ng lahat ng akda ng mga dakilang pilosopo sa mundo, hindi pa ito pamimilosopiya. Maihahalintulad lamang ito sa pagbabasa ng manual ng paglangoy o pagmamaneho nang hindi pa lumulusong sa tubig o humahawak ng manibela (mga halimbawa ng pagmumuning primarya). Hangga't hindi sarili mismo ang tumitingin - hindi bilang tagamasid kundi bilang kasangkot

\footnotetext{
24 Tinatalakay ni Marcel sa ikalimang kabanata ng The Mystery of Being (pp. 83-93) ang dalawang uri ng pagninilay sa kaniyang pagtingin sa karanasan ng pagsasakatawang-diwa ng tao. Maaari ring tingnan ang salin ng kabanatang ito sa Filipino: "Ang Bulangang 'Heto Ako!'," trans. by Nonna J. Peña, in Magpakatao: Ilang Babasahing Pilosopiko, 2nd ed., ed. by Roque J. Ferriols (Quezon City: Office of Research and Publications, Ateneo de Manila University, 1999), 104-128.

${ }^{25}$ Ferriols, Pambungad sa Metapisika, $\mathrm{x}$.
} 


\section{ILANG KATAGANG FILIPINO}

ng karanasan ${ }^{26}$-hangga't hindi lumulundag ang sarili, hindi pa ganap na matatawag na namimilosopiya ang tao.

Ang hulíng puntong nais kong talakayin ay ang hamon ng pamimilosopiya. Kung ito ay tunay na pagninilay, isang tuwinang pagsilay, bakit naituturing na mahirap at di-pangkaraniwan ang pilosopiya? Kailangan nating maunawaan kung bakit itinuturing higit na mahirap ang isang pang-araw-araw na gawain tulad ng pagtingin.

Kung tutuusin, likás sa mga bata ang pagninilay sapagkat nabibihag pa sila ng pagkamangha sa mga bagay. Lahat ng nakikita nila ay bago, kayâ tanong sila nang tanong. Dumaan ang lahat ng tao sa ganitong yugto. Ngunit sa pagkatuto at pagkasanay sa mga bagay sa mundo, nalimutan na natin ang katutubong pananabik matuto (thaumazein, wonder): dahil nalimutan na nating sumilay. Ika ni Ferriols, nababara na tayo sa awtomatiko. ${ }^{27}$ Nasanay na tayo sa mga konsepto kayâ wala nang pagnanasàng sumilay at tumingin. May tiyak na táyong inaasahan sa mga bagay buhat sa ating mga natutuhan. May pagsasantabi sa mga bagong karanasan dahil "alam ko na iyan."

Ito ang hamon ng pilosopiya, na binigkas na ng maraming pilosopo sa nakaraan-ang panatilihin ang pananabik matuto sa kabila ng mga nakasanayan sa mundo. Hinahamon táyong huwag magsawang tumingin at sumilay, kahit sa mga bagay na natingnan at nasilayan na natin dahil hindi kailanman mauubos ang matututuhan natin ukol sa isang bagay.

Samakatuwid, ang pilosopiya ay isang walang sawa at patúloy na pagninilay: ang parating pagtataka at pagtingin sa talaga.

\section{Ang Pagkasumasakasaysayan ng Tao bílang Pagkakataon}

Nakita natin sa nakaraang yugto kung paanong nilalaman ng salitang pagninilay ang kay raming pilosopikong ideya, lalo na kaugnay sa paglalarawan ng kung ano ang pilosopiya. Sa bahaging ito, ilalarawan naman natin ang pagkasumasakasaysayan ng tao sa pamamagitan ng pagkakataon.

Isa sa mga pinakamahalagang paksa, sa palagay ko, na itinatalakay ng Pilosopiya ng Tao, ay ang relasyon ng tao sa kasaysayan. Ipinaliliwanag ni Ramon C. Reyes na "ang tao ay hugpungan ng mga pangyayari." 28 Naroroon ang isang tao sa kinalalagyan niya ngayon dahil sa mga nangyari sa nakaraan, at ihahatid siya ng mga pangyayari sa kasalukuyan sa kung saan man siya mapupunta sa hinaharap. Samakatuwid, ang tao ay bahagi ng

\footnotetext{
${ }^{26}$ Makikita rito ang sinasabi ni Alejo na ang pilosopiya ay isang pakikisangkot. Tingnan ang Tao pô! Tulóy!, 4-5.

${ }^{27}$ Ferriols, Pambungad sa Metapisika, xi.

${ }^{28}$ Salin ng may-akda sa "Man is the 'cross-point' or point of intersection of certain lines of events," mula sa Ramon Reyes, "Man and Historical Action," in Philosophy of Man: Selected Readings, 3rd ed., ed. by Manuel B. Dy, Jr. (Quezon City: Katha Publishing Co., Inc., 2012), 109.

(C) 2018 Noel L. Clemente

https://www.kritike.org/journal/issue 23/clemente december2018.pdf ISSN 1908-7330

(c) $\mathrm{BY}-\mathrm{NC}-\mathrm{ND}$
} 
kasaysayan, at nakikibahagi rin sa paglikha nito; ang tao ay sumasakasaysayan.

Ang sentral na mensahe ni Reyes: parehas na limitasyon at posibilidad ang kasaysayan ng tao. ${ }^{29}$ Ito ang dalawang mukha ng ating pagkasumasakasaysayan. Sapagkat ako ay hugpungan ng mga pangyayari, limitado ang aking maaaring galawan sa mga nangyari na't hindi ko na mababago. Ngunit saanman ako naroroon, mayroon akong mga posibilidad na maaari kong patunguhan. Ang pagiging limitasyon at posibilidad ng ating kasaysaysan ay nagsasanib sa salitang pagkakataon. Kadalasan itong ginagamit bilang oportunidad, ngunit maaari rin itong gamitin bilang koinsidensiya (tulad ng paggamit sa "nagkataon lang"). Ipaliliwanag ko ngayon ang punto ni Reyes sa pamamagitan nitong dalawang gamit ng pagkakataon.

Naririto táyo sa ating kinatatayuan ngayon dahil nangyari na ang mga nangyari sa nakaraan, at wala táyong magagawa sa mga nangyari na. Sinakop na ng mga Kastila, at ng mga Amerikano ang Filipinas; nanungkulan na ang iba't ibang presidente; nagtagpo ang aking mga magulang; bininyagan akong Katoliko Romano; pinaaral ako sa ganitong paaralan; nakilala ko ang mga táong ito; pinili ko itong partikular na landas noong nakaraang taon - at dahil nagkataon ang lahat ng mga ito, naririto ako sa aking kasalukuyan. Samakatuwid, limitado ang aking kasalukuyan ng mga koinsidensiya ng nakaraan. Ito ang dahilan kung bakit makatwirang isisi sa nakaraan ang anumang kasalukuyang kinalalagyan. Kung hindi ko nasagutan ang aking pagsusulit, maaari kong sisihin ang pagkakataong tinamad akong mag-aral kagabi. Kung naging suwail at rebelde ang aking pag-uugali, maaari kong sisihin ang pagkakataon na mahigpit ang pagpapalaki sa akin ng aking mga magulang. Kung kinasusuklaman ko ang Kanluraning impluwensiya sa aking pag-iisip, maaari kong sisihin ang aksidenteng pagkakatagpo ni Magellan sa Mactan noong 1521, o ang pananakop ng mga Amerikano sa bansa noong simula ng ika-dalawampung siglo.

Ngunit iginigiit ni Reyes na tila hindi makatwiran para sa isang tao na habambuhay na isinisisi na lamang sa nakaraan ang kaniyang kalagayan. Isinalaysay ni Reyes ang dati niyang estudyante na isinisisi sa "katangahan at kawalan ng ambisyon" ng kaniyang ama ang kaniyang kahirapan. Nakilala niya itong estudyante nang nása ikalawang taon ito ng kolehiyo, at magpahanggang ikaapat na taon ay patúloy ang paninisi ng estudyante sa kaniyang ama. ${ }^{30}$ Bagaman may katwiran siya sa ganitong paninisi, hindi na yata katanggap-tanggap kung hanggang maging $30 \mathrm{o} 40$ anyos siya ay sa ama

\footnotetext{
${ }^{29}$ Reyes, “Man and Historical Action," 113-114.

${ }^{30}$ Ibid., 113.
}

(c) 2018 Noel L. Clemente 


\section{ILANG KATAGANG FILIPINO}

pa rin niya isisisi ang kaniyang kalagayan sa búhay. Maihahalintulad ito sa isang laro ng baraha. Kapag nakikipaglaro ka sa iyong mga kaibigan ng baraha, binabalasa (kung walang nandaraya) nang tapat ang mga baraha. Sa unang minuto, pamilyar na eksena ang paninisi sa sinumang nagbalasa kung bakit pangit ang mga barahang nakuha ng isang manlalaro. Nagkataon lang naman na yaon ang mga napunta sa kaniya, at wala na siyang magagawa; limitado ang tsansa niyang manalo sa kalidad ng mga baraha niya. Ngunit hindi yata makatwiran kung lilipas ang isang oras at hindi pa rin siya nakikipaglaro dahil patuloy ang paninisi niya sa kalarong nagbalasa. Kailangang umabot sa punto na tanggapin niya ang mga barahang naibigay sa kaniya at maglaro na lang gamit ng mga ito.

Dito pumapasok ang posibilidad ng kasaysayan na kaakibat ng mga limitasyon nito; sapagkat nagkataon (konsidensiya) ang mga pangyayari sa nakaraan, mayroong pagkakataon (oportunidad) ang tao na kumilos at magpasiya. ${ }^{31}$ Ang nagkataong pangkat ng mga baraha na napunta sa isang manlalaro ang siya ring nagbibigay sa kaniya ng pagkakataong maglaro. Hindi man niya mapipili kung aling mga baraha ang mapupunta sa kaniya, mapipili naman niya kung paano niya lalaruin ang mga ito. Hindi dapat limutin ang pagkakatali ng kaniyang mga posibilidad sa kaniyang limitasyon; mahihirapan man siyang manalo kung pangit ang kaniyang mga baraha, hindi nito ibig sabihing imposible ang manalo. Gayundin, mahihirapang mamuhay nang maayos at matiwasay ang isang táong hindi pinagpalà ng mga biyaya sa búhay, ngunit may káya pa rin siyang gawin sa anumang kakaunti na naibigay sa kaniya. Sa kabilâng banda, hindi rin naman ibig sabihin na kung magaganda ang baraha ay mananalo na agad ang isang manlalaro, tulad ng hindi ibig sabihin na kung marangya at sagana ang pinanggalingan ay madadalian na siyang makipagsapalaran sa búhay. Dito natin makikita na hindi sapat ang suwerte sa laro (at sa búhay); mahalaga rin ang diskarte.

Samakatuwid, bagaman limitado ang ating kasaysayan, hitik din tayo sa posibilidad dahil dito. Sapagkat naririto na ako sa aking kinatatayuan, marami akong maaaring arami akong maaaring tahaking landas. Nagkataong ipinanganak ako sa Filipinas, at isa itong pagkakataong magpaka-Filipino. Maaari kong piliing lisanin ang bansa kalaunan o maaari akong manatili, pero anupaman ang mangyari, mayroon akong pagkakataon. Nagkataong mga Katoliko ang aking mga magulang kayâ ako bininyagang Katoliko, at isa itong pagkakataong magpaka-Katoliko, o maaari ring pagkakataong tumiwalag sa aking relihiyon. Nagkataong naging kaklase ko

\footnotetext{
${ }^{31}$ Pinuna ni Donald Jay Bertulfo na mas palasak ang gamit ng mga Filipino sa salitang "pagkakataon" bilang oportunidad kaysa koinsidensiya. Maaaring may sinasabi ito sa tendensiya ng mga Filipino na bumaling sa mga posibilidad sa halip na sa mga limitasyon, sa hinaharap sa halip na sa nakaraan.
}

(c) 2018 Noel L. Clemente

https://www.kritike.org/journal/issue 23/clemente december2018.pdf ISSN 1908-7330

(c) BY-NC-ND 
ang táong ito, at isa itong pagkakataong makilala siya at makipagkaibigan, o maaari ring pagkakataong isantabi siya at piliing hindi maging bahagi ng búhay ko.

Dito natin nauunawaan ang kasaysayan ng tao bilang isang pagkakataon: sabay na nagkataon lamang at wala nang magagawa ang tao, at isang pagkakataon na maaaring samantalahin ng tao. Manapa, naipapakita rin ito ng katagang pagtatakda. Kapag sinabi nating "naitakda na," may ibang entidad na nagpataw sa atin ng isang pangyayari, at wala na tayong magagawa rito. Ngunit ginagamit din natin ang salitang "takda" bilang isang gawain: na para bang takdang-aralin ng isang mag-aaral. Itinakda sa atin ang ating kasaysayan: muli, sabay na limitasyon at posibilidad. Katulad ng pagkakataon, nahuhúli rin ng pagtatakda ang dalawang mukha ng pagkasumasakasaysayan ng tao, ngunit mas naipapahiwatig nito ang kalayaan ng tao. Sapagkat limitado ang tao sa kaniyang kasaysayan, limitado rin ang kaniyang kalayaan. May mga "naitakda na" na hindi niya mababago. Sa kabilâng banda, anuman ang kaniyang limitasyon, naglalaman pa rin ito ng mga posibilidad, kayâ hindi rin masasabing radikal na determinado ang kaniyang kasaysayan.

Maaari rin nating iugnay ang pagiging pagkakataon ng kasaysayan sa salitang-ugat ng 'kasaysayan': saysay. Marahil, isa ito sa pinakapalasak na pagpapahayag ng pangunahing tanong sa ating búhay: Ano ba ang saysay ng ating búhay? Bakit ako umiiral? Ano ang papel ko sa mundong ito? Makatutulong sa paghahanap ng sagot sa tanong na ito ang pagkilala sa mga limitasyon at posibilidad ng ating pagkatao. Sa isang banda, ang saysay ko ay naitakda na ng aking nakaraan. Nagkataon na ganito ang kontekstong aking sinilangan, kayâ may hangganan ang mga maaari kong piliing landas. Gayunpaman, isa ring patuloy na takda ang paghahanap na ito ng saysay ng aking búhay; saanman ako naroroon sa kasalukuyan ay may pagkakataon akong pumili ng aking patutunguhan.

\section{Pilosopiya ng Tao bílang Pagpapahayag ng Tao po!}

Ang huli kong gustong pag-usapang kataga na nagpapalawig, hindi lang ng pamimilosopiya at ng pagiging tao, kundi ng mismong pamimilosopiya ukol sa tao, ay ang "tao po." Halaw ang pagtalakay na ito sa pagpapaliwanag ni Alejo ng pamagat ng kaniyang aklat. Sa Tao po! Tulóy!, inilalarawan at sinusuri ni Alejo ang loob, isang Filipinong kataga, konsepto, at katotohanan. Paliwanag niya, maaaring ihambing ang loob sa ibang mga obheto ng pilosopiya. Itinuring ng mga sinaunang Griyego ang katotohanan bilang aletheia, na nangangahulugang pag-alis mula sa pagkakakubli; samakatuwid kung gusto mong maunawaan ang aletheia, tingnan mo kung ano ang nagpapakita. Sentral naman kina Lao Tzu at Chuang Tzu ang Dao o 


\section{ILANG KATAGANG FILIPINO}

landas; kung gusto mong maunawaan ang Dao, bagtasin mo ang landas na ito. Sa gayon, kung gusto mong maunawaan ang loob ng tao, kailangan mong tumuloy sa loob. ${ }^{32}$ Ngunit, sa kaugaliang Filipino, hindi basta-basta ang pagpasok sa loob. Bílang paggalang, kailangan mo munang magpaálam, at karaniwang ipinapahayag itong pagpapaálam sa pagsambit ng "Tao po!" kasabay ng pagkatok sa pinto. At hinihintay niya muna ang tugon na "Tulóy" ng nása loob. Sa isang payak at pamilyar na palítang ito, marami tayong matututuhan ukol sa pakikiugnay ng mga tao.

Pagtuunan natin ng pansin ang mga katagang "tao po." May dalawa itong maaaring ipinahihiwatig. Una, isa itong pagpapahayag ng "May tao po rito!". Sa pamamagitan ng pagkatok sa pinto, nais mong ipaalam sa nása loob na may tao sa labas. Ikalawa, maaari rin itong pagtatanong o paghahanap ng tao sa loob, na para bang nagtatanong ng "May tao po ba riyan?" Ipinahihiwatig ng dalawang mukha nito ang karaniwang paghahati ng pagtuturo ng Pilosopiya ng Tao: sinisimulan ito sa mga tema ng pagtuklas sa sarili bílang tao (eksistensiyal), bago tumungo sa mga tema ng pagkilala sa ibang kapuwa tao (panlipunan). ${ }^{33}$ Ngunit sa pagbigkas ng "tao po," sa konteksto ng pagkatok bago pumasok sa loob, iminumungkahi ang sabay na pagpapahayag ng sarili at paghahanap ng kapuwa.

May matututuhan din tayo sa salitang kapuwa. Binabaybay rin ito bilang "kapwa," ngunit pinipili kong gamitin ang "kapuwa" dahil may iminumungkahi itong orihen ng salita. Maaaring tingnan ang "kapuwa" bilang pinaikling "ka-puwang," isang kahati sa puwang. ${ }^{34}$ Ang aking kapuwa ay ang tao na kabahagi ko sa puwang ng daigdig. Mapapansing hindi lamang pisikal o obhetibong puwang ang tinutukoy rito. Isa sa mga pinakamalalim na punto ng Pilosopiya ng Tao ay ang realisasyon na ano pa man ang ating angkan, kasarian, edad, o paniniwala, lahat tayo ay mga kapuwa tao, at iyon ang maaari nating pagsimulan ng pakikipag-ugnay.

Bilang pagpapatúloy ng pagtalakay sa "tao po," maaari nating idagdag ang pagsusuri ni Ricoeur sa Parabula ng Mabuting Samaritano. ${ }^{35}$

${ }^{32}$ Alejo, Tao pô! Tulóy!, 68.

33 Sa Pamantasang Ateneo de Manila, halimbawa, tinuturo ang Pilosopiya ng Tao sa dalawang magkasunod na kurso. Karamihan ng mga guro ay nagtutuon sa sarili sa PH101, at sa lipunan naman sa PH102.

${ }^{34}$ Kung tama ang aking pagkakatanda, sa isang klase ni Remmon E. Barbaza ko unang narinig ang ganitong mungkahi sa pahiwatig ng salitang "kapuwa." Sinubukan kong kumpirmahin ito sa diksiyonaryo, ngunit walang ganitong ipinapahayag na orihen. Gayunpaman, hindi imposibleng magkaugnay ang salitang ito sa "ka-puwang" na may malalim na sinasabi tungkol sa kahulugan nito. Nakikiusap ako sa ibang mananaliksik na mayroong masasabi sa ganitong lingguistikong pagsusuri, na mag-bahagi ng isa mang pagkumpirma o pagtuligsa, para rin maging tapat ang paggamit nitong salita sa kaniyang pinagmulan.

35 Paul Ricoeur, "Ang Kalipunan at ang Kapwa," in Pilosopiya ng Tao: Ilang Piniling Babasahin Tomo I, ed. by Antonette Palma-Angeles, Rofel G. Brion, et. al., trans. by Albert Alejo (Quezon City: Kagawaran ng Pilosopiya, Pamantasang Ateneo de Manila, 1988), 149-164,

(c) 2018 Noel L. Clemente

https://www.kritike.org/journal/issue 23/clemente december2018.pdf

ISSN 1908-7330

(cc) BY-NC-ND 
Aniya, ang kapuwa ay hindi sosyolohikal na kategoriya, kundi kilos ng sarili; ginagawa kong kapuwa ang sarili ko sa pakikipag-ugnay sa kaniya. Dito, nagsasabay ang danas ng 'ako' at ng 'kapuwa'; nagiging kapuwa ako sa pamamagitan ng aking kilos. Samakatuwid, hindi hiwalay ang ako at ang kapuwa. Hindi ko mauunawaan ang ako nang hiwalay sa kapuwa, at hindi ko mauunawaan ang kapuwa nang hiwalay sa akin. Ito ang nagaganap sa pamimilosopiya ng tao. Kumakatok ako sa pinto ng aking kapuwa, binibigkas ang "Tao po!" bilang pagpapakilala ng sarili ko bilang tao, samantalang hinahanap ang kapuwa ko na alam kong katulad kong tao.

Tulad ng nabanggit sa ikalawang seksiyon, ang pamimilosopiya ay mas maihahanay sa pagmumuning sekundarya, kung saan isinasangkot ko ang sarili ko. Kaakibat ng pagsangkot ng aking sarili ang pagtataka ukol sa kapuwa. Samakatwid, nakikilala ko ang kapuwa hindi sa paraan ng pagsisiyasat sa kaniya na para bang isang specimen sa isang laboratoryo, kundi sa aking mismong pakikihalubilo sa kaniya. Kaakibat nito, lalo ko ring nakikilala ang sarili ko sa pakikiugnay sa iba-sabay na paglantad ng sarili, "May tao po rito!", sa paghahanap ng makauugnay na kapuwa, "May tao po ba riyan?"

\section{Pangwakas}

Taliwas sa palagay ni Quito, mayamang-mayaman ang ating wika sa mga salita na hitik sa pilosopikong kahulugan. Marami táyong matututuhan sa pagsisiyasat ng ating mga kataga; ang aking mga iminungkahi sa mga nakaraang bahagi ay ilan lamang halimbawang panimula. Hindi man maiiwasan na ihambing ang mga nabanggit ko sa mga Europeong konsepto na marahil mas kilalá na sa akademya, igigiit kong iba pa rin ang danas ng ating mga salita sa kanila.

Bilang pangwakas, nais kong magbigay pa ng dalawa pang mga katagang Filipino na masasabi ring bukál ng pilosopikong diskurso. Tulad ng mga tinalakay kong kataga sa mga naunang seksiyon, masasabing nakapaloob sa mga katagang ito ang mga nasabi na ng mga pilosopong Europeo, na nagpapahiwatig na buháy sa ating kultura ang danas ng kanilang mga nasabi. Ipaliliwanag ko lang nang bahagya ang kaugnayan ng mga ibibigay kong salita sa mga pilosopikong ideya, ngunit iiwan kong bukás ang diskusyon sa mga katagang ito.

Isang karaniwang paksa sa Pilosopiya ng Tao ang mga pananaw ni Karl Marx ukol sa alyenadong paggawa. Ginagamit nating salita sa trabaho ang hanapbuhay, na nagpapahiwatig ng sinasabi niyang ikatlong anyo ng 


\section{ILANG KATAGANG FILIPINO}

alyenasyon, ang alyenasyon sa pag-iral na pantao. ${ }^{36}$ Ayon kay Marx, dulot ng alyenasyon ng manggagawa sa produkto at sa mismong akto ng paggawa, ibinubuhos ng manggagawa ang kaniyang sarili sa produktong hindi nagiging kaniya. Dahil dito, nagiging banyaga sa kaniya ang pag-iral na bukod tanging para sa mga tao lamang: ang kakayahang gumawa nang lagpas sa kinakailangan. Nakapagtatrabaho rin naman, halimbawa, ang mga langgam sa paggawa nila ng punso, mga bubuyog sa paglikha nila ng bahaypukyutan, o mga gagamba sa paghabi nila ng sapot, ngunit ang mga ito ay tawag ng pangangailangan nilang mabuhay. Tao lamang, para kay Marx, ang may kakayahang lumikha ng mga bagay na hindi naman niya kinakailangan upang mabuhay, tulad ng smartphone, tula, awit, puntod, atbp. Subalit sa paggawa ng manggagawa ng produktong hindi mapapasakaniya, napapako ang kaniyang paggawa sa pangangailangan, at maihahambing na lang siya sa mga langgam, bubuyog, at gagamba. Samakatuwid, kung ang trabaho ay hamak na paghahanap-ng-búhay, sa literal na kahulugan na ginagawa niya ito para lamang mabuhay, nakararanas siya ng alyenadong paggawa.

Maaari ring suriin ang katagang karapatan. Ang salitang ugat nito ay 'dapat.' Ang karapatan ay ang napagkasunduang mga "dapat" ng isang pamayanan. Kung nais ng mga mamamayan na mamuhay nang matiwasay, kailangan nilang igalang ang karapatan ng isa't isa, at kaugnay nito, kailangan nilang sundin ang mga kaugnay na patakaran. (Nakatutuwang punahin na anagrama ng "karapatan" ang "patakaran.") Ngunit parating may konteksto ang mga karapatan; nagkakaroon ang isang entidad ng karapatan bilang bahagi ng isang pangkat. Ang mga karapatang pantao ay karapatan natin bilang mga tao (kaya nga may Universal Declaration of Human Rights ang United Nations; unibersal ang mga karapatang ito para sa lahat ng tao); ang mga karapatang sibil ay karapatan ng isang mamamayan bilang napapasailalim sa isang pamahalaan; ang mga karapatang pambabae ay karapatan na natamo sa mismong pagiging babae. Kaugnay ng pagiging bahagi ng isang pangkat, mayroong mga nararapat (at di-nararapat) para sa mga taong ito. Mula rito, maaari pang suriin ang katagang "karapatan" bilang pundasyon ng isang pilosopiyang panlipunan nating mga Filipino.

Umaasa akong ang pagbabahaging ito ng mga ideya hinggil sa mga salitang Filipino na maituturing na bukal ng diwang pilosopiko ay maging isang munting ambag sa pagpapatuloy ng tradisyon ni Ferriols ng pagtuturo ng pilosopiya at pamimilosopiya sa wikang Filipino. Hinihimok ko ang aking mga mambabasa na ipagpatuloy ang ganitong pagpapahalaga at paglilinang sa ating wika sa larangan ng pamimilosopiya.

36 Ang "pag-iral na pantao" ay salin ng may-akda sa "species-being." Karl Marx, "Alienated Labor," in Karl Marx: Selected Writings, 2nd ed., ed. by David McLellan (Oxford: Oxford University Press, 2000), 89-91.

(C) 2018 Noel L. Clemente

https://www.kritike.org/journal/issue 23/clemente december2018.pdf ISSN 1908-7330

(c) $)$ BY-NC-ND 


\section{Pasasalamat at Pagkilala}

Nais kong pasalamatan sina Precious De Joya at Albert Alejo na humimok sa aking isulat ang papel na ito, pati na rin ang mga tagapagbasáng napili ng Kritike para sa kanilang mahahalagang puna sa unang burador nitong manuskrito. Nais ko ring kilalanin ang mga ambag at mungkahi nina Danna Aduna, Jayne Tinhay Arriola, at Donald Jay Bertulfo.

Department of Philosophy, Ateneo de Manila University, Philippines

\section{References}

Alejo, Albert E., Tao pô! Tulóy! Isang Landas ng Pag-unawa sa Loob ng Tao (Quezon City: Ateneo de Manila University Office of Research and Publications, 1990).

Aristotle, Metaphysics, trans. by W.D. Ross, in The Basic Works of Aristotle, ed. by Richard McKeon. (New York: Random House, 1941).

Calano, Mark Joseph, "Ang Pilosopiya at si Roque J. Ferriols, SJ," Perspectives in the Arts and the Humanities 5:1 (2015)

Cortez, Franz, Giuseppe F., "The Linguistic Turn as a Political Act: Another Look at the Thoughts of Roque Ferriols," Kritike: An Online Journal of Philosophy, 8:1 (June 2014).

Ferriols, Roque J., “A Memoir of Six Years,” Philippine Studies 22 (1974).

Pambungad sa Metapisika (Quezon City: Ateneo de Manila University Press, 2014)

Lagliva, Albert M., "Ang Paraan at mga Elemento ng Pagtuturo ni Roque J. Ferriols, SJ, tungo sa Matinong Pag-Uunawa," Perspectives in the Arts and Humanities Asia 5:1 (2015).

Marcel, Gabriel, “Ang Bulangang 'Heto Ako!',” trans. by Nonna J. Peña, in Magpakatao: Ilang Babasahing Pilosopiko, 2nd ed., ed. by Roque J. Ferriols (Quezon City: Office of Research and Publications, Ateneo de Manila University, 1999).

Reflection and Mystery, vol. 1 of The Mystery of Being, trans. by G.S. Fraser (London The Harvill Press, 1951).

Marx, Karl, "Alienated Labor," in Karl Marx: Selected Writings, 2nd ed., ed. by David McLellan (Oxford: Oxford University Press, 2000)

Mercado, Leonardo N., Elements of Filipino Philosophy (Tacloban City: Divine Word University Publications, 1993).

Oris, Glenda C., "Ferriols on Ferriols and More," Perspectives in the Arts and Humanities Asia 5:1 (2015).

(C) 2018 Noel L. Clemente

https://www.kritike.org/journal/issue 23/clemente december2018.pdf

ISSN 1908-7330 


\section{ILANG KATAGANG FILIPINO}

Que, Nemesio S. and Agustin Martin G. Rodriguez, eds., Introduction to Pagdiriwang sa Meron: A Festival of Thinking Celebrating Fr. Roque J. Ferriols, S.J. (Quezon City: Ateneo de Manila University, 1997).

Quito, Emerita S., "Ang Kayamanan ng Wikang Filipino," in A Life of Philosophy: Festschrift in Honor of Emerita S. Quito (Manila: De La Salle University Press, 1990).

Lectures on Comparative Philosophy (Manila: De La Salle University Press, 1979).

Reyes, Ramon, "Man and Historical Action," in Philosophy of Man: Selected Readings, 3rd ed., ed. by Manuel B. Dy, Jr. (Quezon City: Katha Publishing Co., Inc., 2012).

Ricoeur, Paul, "Ang Kalipunan at ang Kapwa," in Pilosopiya ng Tao: Ilang Piniling Babasahin Tomo I, ed. by Antonette Palma-Angeles, Rofel G. Brion, et. al., trans. by Albert Alejo (Quezon City: Kagawaran ng Pilosopiya, Pamantasang Ateneo de Manila, 1988).

Strebel, Wilhelm P.J., "Pitong Sulyap sa Pilosopiya ng Wika ni Ferriols," Kritike: An Online Journal of Philosophy, 12:1 (June 2018).

Tolentino, Roy Allan B., "Biyaya ang Meron, Biyaya ng Meron: Ang Pag-iisip nina Ferriols, Marion, at San Agustin," Perspectives in the Arts and Humanities Asia 5:1 (2015).

Wittgenstein, Ludwig, Philosophical Investigations, rev. 4th ed., ed. by P.M.S. Hacker and Joachim Schulte, trans. by G.E.M. Anscombe, P.M.S. Hacker, and Joachim Schulte (Malden: Wiley-Blackwell, 2009). 
Article

\title{
A Humboldtian Critique of the University of the Philippines as the Flagship of Philippine Higher Education (Part I)
}

\section{F.P.A. Demeterio III Roland Theuas DS. Pada}

\begin{abstract}
For the Philippines to benefit from the ASEAN integration and globalization, in general, it must be able to mold highly educated citizens who can proactively engage themselves with the national, regional, and international knowledge economies. ${ }^{1}$ The Philippines has nine research universities that presumably lead its approximately 2,500 higher educational institutions in molding these needed citizens. These nine research universities are the eight autonomous constituent units of the University of the Philippines and De La Salle University. The idea of the modern research university was invented more than 200 years ago in Berlin by the philosopher, linguist, humanist, and statesman Wilhelm von Humboldt (1767-1835). Around 1850, American educational leaders started to appropriate Humboldt's ideas to establish the American research universities. As the University of the Philippines is an American creation and at the same time the flagship institution of Philippine higher education, this paper used the Humboldtian philosophy of education, as well as its American rendition, in looking at the soundness of this university's claim to be a research university. To attain this goal this paper has three substantive sections: 1) a discussion on Humboldt's philosophy of education, 2) a discussion on the American translation of Humboldt's philosophy of education, 3) a critique of the foundational principles of the University of the Philippines as a research university.
\end{abstract}

Keywords: Wilhelm von Humboldt, Humboldtian research university, American research university, Philippine higher education

${ }^{1}$ Philip G. Altbach, "The Past, Present, and Future of the Research University," in The Road to Academic Excellence: The Making of World-Class Research Universities, ed. by Philip G. Altbach and Jamil Salmi (Washington, D.C.: The World Bank, 2011), 11.

(C) 2018 F.P.A. Demeterio III and Roland Theuas DS. Pada

https://www.kritike.org/journal/issue 23/demeterio\&pada december2018.pdf

ISSN 1908-7330

$(\mathrm{Cc}) \overline{\mathrm{BY}-\mathrm{NC}-\mathrm{ND}}$ 


\section{A HUMBOLDTIAN CRITIQUE}

7 he idea of the modern research university was invented more than 200 years ago in Berlin, the capital at that time of the Kingdom of Prussia, by the German philosopher, linguist, humanist, and statesman Wilhelm von Humboldt (1767-1835). Around 1850, American educational leaders started to appropriate Humboldt's ideas to establish the American research universities. ${ }^{2}$ UP was founded by the Philippine Legislative Assembly, under the American colonial government in 1908. In 1972, the whole University of the Philippines was reorganized into a system, which eventually had eight constituent autonomous units, namely: 1) University of the Philippines Los Baños, 1972; 2) University of the Philippines Manila, 1979; 3) University of the Philippines Visayas, 1979;4) University of the Philippines Diliman, 1985; 5) University of the Philippines Open University, 1995; 6) University of the Philippines Mindanao, 1995; 7) University of the Philippine Baguio, 2002; and 8) University of the Philippines Cebu, 2010. UP is the flagship university of the country per R.A. 9500.

\section{Introduction}

As UP is an American creation and at the same time the flagship institution of Philippine higher education, this paper used Humboldt's philosophy of education as well as its American rendition in looking at the soundness of this university's claim as a research university. To attain this goal this paper has three substantive sections: 1) a discussion on Humboldt's philosophy of education, 2) a discussion on the American rendition of Humboldt's philosophy of education, and 3) a critique of the foundational principles of UP as a research university.

The first section was formulated by mainly using Humboldt's short essay, titled "On the Internal and External Organization of the Higher Scientific Institutions in Berlin," as well as some English language commentaries on the Humboldtian educational revolution. The second section was written by using English language accounts of how Humboldt's ideas reached the United States of America and how these were eventually instrumental to the development of the so-called American research university. The third section was done by articulating it into four sub-sections representing four periods of UP: 1) the university under the American colonization (1908-1946), 2) the university after the liberation (1946-1972), 3) the university as a system (1972-2008), and 4) the university's transition to a research university (2008-present). Key documents from each of these four periods are examined from the perspective of Humboldt's philosophy of

2 Daniel Fallon, "German Influences on American Education," in The German-American Encounter: Conflict and Cooperation between Two Cultures, ed. by Frank Trommler and Elliott Shore (New York: Berghahn Books, 2002), 85.

(C) 2018 F.P.A. Demeterio III and Roland Theuas DS. Pada

https://www.kritike.org/journal/issue 23/demeterio\&pada december2018.pdf ISSN 1908-7330

(c) $)$ BY-NC-ND 
education as well as its American translation. These documents are mentioned in the respective subsections under the third section of this paper. As a disclaimer for this study, our scope of analysis of UP's attempt to adopt the American translation of Humboldt's is based on archival documents to support our main arguments. Our study will not cover other factors such as the political, social, and other areas that are not covered in the archival documents of the University of the Philippines.

The insights that are culled by this paper can be helpful in the research planning and management of not only the country's nine research universities but also of the other Philippine universities that aim to boost their research productivities and/or move towards the Humboldtian model, or any other current dominant model, of the research university. With the looming ASEAN integration, a self-respecting Philippine higher educational institution has actually very little option left but to beef up its research capacity in order to compete with the real research universities within the ASEAN region.

The Commission on Higher Education's Memorandum Order 46, Series of 2012, is adding to this pressure. Among other things, this memorandum order intends to classify the existing Philippine higher educational institutions into professional institutions, colleges, or universities. Research is one of the bottlenecks for current universities to maintain their university classification or for current colleges to move up to the status of a university.

A literature search on Philippine research universities made through Google Scholar in April 2017 generated no relevant material. Hence, this paper could be the first published material that problematizes the research university in the Philippine setting. This paper also provides some preliminary groundwork for the succeeding efforts in formulating models of the research university that could be suitable to Philippine conditions.

\section{Humboldt's Philosophy of Education}

\section{Intellectual Biography and Social Context}

Humboldt was born in Potsdam in 1767. He started his higher education at the Prussian University in Frankfurt an der Oder but transferred to Gottingen University and studied jurisprudence, philology, natural sciences, and philosophy, particularly the one of Immanuel Kant. ${ }^{3}$ After finishing his studies in 1790 he went to Berlin to work in the Prussian

${ }^{3}$ Hermann Klencke and Gustav Schlesier, Lives of the Brothers Humboldt, Alexander and William (London: Ingram, Cooke, and Company, 1852), 253.

(c) 2018 F.P.A. Demeterio III and Roland Theuas DS. Pada https://www.kritike.org/journal/issue 23/demeterio\&pada december2018.pdf ISSN 1908-7330 


\section{A HUMBOLDTIAN CRITIQUE}

government. But only one year in civil service, he resigned, went to Jena, married, and stayed in that city up to 1797. At the University of Jena, he interacted with the romantic thinkers Johann Gottlieb Fichte, the brothers Friedrich and August Wilhelm Schlegel, Johann Wolfgang von Goethe, and Friedrich Schiller. ${ }^{4}$ From 1797 to 1801, Humboldt and his family stayed in Paris. It was during this period where his linguistic turn happened, fueled by his curiosity with the Basque language. He even went to Spain in order to study this language in its natural setting. From 1803 to 1808, Humboldt was back in the Prussian civil service, working as envoy to the Vatican. In Rome, he studied some native American languages.

From 1808 to 1810, Humboldt was back in Berlin to work under the Minister of the Interior as head of the ecclesiastical and education section. ${ }^{5}$ It was during the short period of work in the Prussian capital when he effected the so-called Humboldtian revolution in education by founding the University of Berlin. Without seeing the inauguration of the said university, Humboldt was sent to Vienna as the Prussian ambassador to Austria. ${ }^{6}$ There, he continued his linguistic studies. Around 1815, he was then reassigned as the Prussian representative to the German Confederation in Frankfurt am Main and was soon transferred to London as the Prussian ambassador to England. In 1819, he was back to Berlin to assist the Ministry of the Interior in drafting a new constitution for Prussia. However, in the same year, he was dismissed from the civil service due to some key disagreements with his superiors. He stayed near Berlin and spent his remaining time and energy for his scholarly works. He died in 1835 at the age of 67.

With Humboldt's very swift implementation of his educational revolution, one cannot help but wonder how he managed to effectuate this feat in such a short time. He was, of course, addressing some concrete and historical conditions that begged for a much-needed reformation of the Prussian educational system. The most salient among these concrete and historical conditions were: 1) Prussians who were defeated and humiliated by France and Napoleon Bonaparte and who were therefore clamoring for sociopolitical and cultural reforms; ${ }^{7}$ 2) a mercantilist orientation of pursuing research in the German universities, where such institutions pressure their professors to do research in order to increase the fame of their respective universities and contribute to the income of their respective cities and states; ${ }^{8}$

\footnotetext{
${ }^{4}$ Ibid., 287-299.

5 Ibid., 346.

${ }^{6}$ Ibid., 362.

${ }^{7}$ Ibid., 355.

${ }^{8}$ Chad Wellmon, Organizing Enlightenment: Information Overload and the Invention of the Modern Research University (Baltimore, MD: Johns Hopkins University Press, 2016), 222. See also Peter Josephson, "The Publication Mill: The Beginnings of Publication History as an Academic Merit in German Universities, 1750-1810," in The Humboldtian Tradition: Origins and Legacies, ed.
} 
3) professors who were financially lured to do research at the expense of relegating their teaching function as a task of lesser importance; $\left.{ }^{9} 4\right)$ the proliferation of printed books that had collectively been deemed as a less expensive replacement of professors as the main transmitters of knowledge; ${ }^{10}$ 5) an emerging concept of knowledge, from being something that is already made and complete and can be easily transmitted to being something that is always in the process of becoming and can never be completed and therefore cannot be easily transmitted;11 and 6) cities and states with diverse and unrelated learning institutions, such as primary schools, secondary schools, universities, specialized schools (such as the ones dealing with veterinary medicine, mining, trade, and the like), academies, anatomical theatres, libraries, museums, menageries, and botanical gardens. ${ }^{12}$

In addition to these concrete and historical conditions that pleaded for reforms, Humboldt also had his own sources, inspirations, models, and collaborators: 1) Gottingen University, which was one of the leading German universities at that time, where research was seriously pursued by its professors, and where Humboldt studied; ${ }^{13}$ 2) the University of Jena, which was also one of the leading German universities at that time, where academic freedom flourished, great intellectuals congregated, and where Humboldt lived nearby for a while; ${ }^{14} 3$ ) the philosopher Kant, who proposed that the faculty of philosophy should be at the heart of a university, since it is the faculty that can manage and critique knowledge, and who was one of the subjects of Humboldt's studies in Gottingen; ${ }^{15}$ and 4) the philosophers, man of letters, scientists, and philologists Fichte, Friedrich Schelling, Henrik Steffens, and Friedrich Schleiermacher, who already penned down some sketches on how to reform the German universities. ${ }^{16}$

One of the most amazing accomplishments that Humboldt had was to synthesize all his sources, inspirations, models, and collaborators' ideas as he addressed the concrete and historical conditions that begged for reforms.

by Peter Josephson, Thomas Karlsohn, and Johan Östling (Leiden: Brill Academic Publishers, 2014), 26-27.

${ }^{9}$ Josephson, “The Publication Mill," 28-29.

${ }^{10}$ Wellmon, Organizing Enlightenment, 225.

${ }^{11}$ Ibid., 220.

12 Klencke and Schlesier, Lives of the Brothers Humboldt, 362.

${ }^{13}$ Wellmon, Organizing Enlightenment, 211.

${ }^{14}$ Theodore Ziolkowski, "The Nineteenth-Century German University and German Idealism," in Reexamining Academic Freedom in Religiously Affiliated Universities: Transcending Orthodoxies, ed. by Kenneth Garcia (Cham: Palgrave Macmillan, 2016), 37.

${ }^{15}$ Sven-Eric Liedman, "In Search of Isis: General Education in Germany and Sweden," in The European and American University Since 1800: Historical and Sociological Essays, eds. Sheldon Rothblatt and Bjorn Wittrock (Cambridge: Cambridge University Press, 1993), 82.

16 Michael Peters, "On Narratives of Self-Formation and Education," in Psychosociological Issues in Human Resource Management, 3:2 (2015), 124-125.

(c) 2018 F.P.A. Demeterio III and Roland Theuas DS. Pada https://www.kritike.org/journal/issue 23/demeterio\&pada december2018.pdf ISSN 1908-7330 


\section{A HUMBOLDTIAN CRITIQUE}

He consolidated these in a master plan for the creation of the University of Berlin, as well as for the rationalization of the whole Prussian educational system, in that short window of time when he was able to convince the Prussian government to implement such master plan.

\section{The Foundation of the University of Berlin}

In 1808, Humboldt submitted to King Friedrich Wilhelm III of Prussia his master plan for the establishment of the University of Berlin. During the inauguration of the university, the Prussian king uttered the prophetic words: "the state must replace by intellectual powers what it has lost in material power." 17

Figure 1 schematically represents Humboldt's philosophical vision of the modern university. At the heart of the modern university, represented by a circle inside the triangle, is the dynamic and infinite conception of knowledge/science: "everything depends on preserving the principle of seeing science as something that has not been and can never be entirely found, and to constantly pursue it as such." 18 As already mentioned, one of the concrete and historical conditions that begged to be addressed by higher education was the emerging concept of knowledge and science from being something that is already made and complete and can be easily transmitted to being something that is always in the process of becoming and can never be completed and, therefore, cannot be easily transmitted. For Humboldt, teaching knowledge/science as something already made and complete is only good for the secondary school. ${ }^{19}$ It is a concession that he had to make to make secondary education capable of dispensing the broadest possible preparatory knowledge to its younger students. But in the modern university, knowledge/science should be taught as it really is: always in the process of becoming and never to be completed.

\footnotetext{
${ }^{17}$ Pieter Dhondt, "Humboldt in Belgium: Rhetoric on the German University Model," in The Humboldtian Tradition: Origins and Legacies, ed. by Peter Josephson, Thomas Karlsohn, and Johan Östling (Leiden: Brill Academic Publishers, 2014), 101.

18 Wilhelm Humboldt, "On the Internal and External Organization of the Higher Scientific Institutions in Berlin," in German History in Documents and Images, vol. 2, From Absolutism to Napoleon (1648-1815), ed. by William Hagen (Washington, D.C.: German Historical Institute, n.d.), http://germanhistorydocs.ghi-dc.org/sub_document.cfm?document_id=3642, 30 July 2017.

${ }^{19}$ Ibid., 1.

(c) 2018 F.P.A. Demeterio III and Roland Theuas DS. Pada

https://www.kritike.org/journal/issue 23/demeterio\&pada december2018.pdf

ISSN 1908-7330
}

(c) BY-NC-ND 


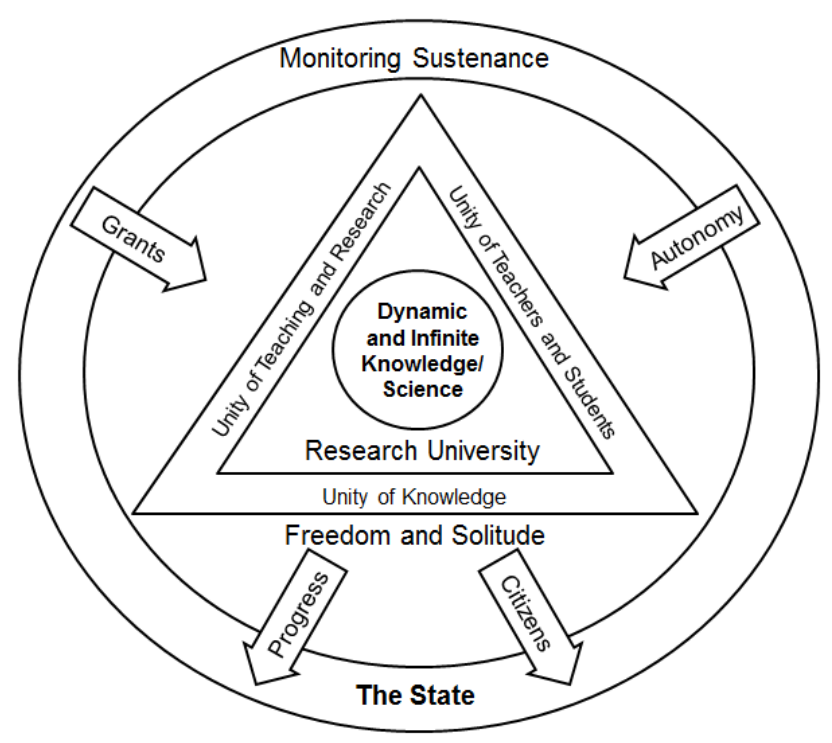

Figure 1: Schematic Representation of Humboldt's Philosophical Vision of the Modern University

For Humboldt, there are three unities in the modern university. ${ }^{20}$ The first of these unities is the unity of teaching and research, represented by the left side of the triangle. ${ }^{21}$ This unity implies that research is utilized as a method of teaching, and teaching is used as part of the research process. As also already mentioned, one of the concrete and historical conditions that required attention by higher education was the unfortunate situation where professors were financially lured to do research with the unintended consequence that they pursued research at the expense of relegating their teaching function as a task of lesser importance. This created the dichotomy between teaching and research in the traditional university. This dichotomy was banished forever in the modern research university in the sense that a good professor would always be a good researcher and a good teacher at the same time.

The second of the three unities mentioned by Humboldt is the unity of teachers and students, represented by the right side of the triangle. ${ }^{22}$ This unity implies that professors are expected to do research in collaboration with their students. The students need the experience and expertise of the professors for them to be introduced and trained in the process of research and learning. On the other hand, the professors also need the fresh ideas and out-of-the-box thinking and perspective of the students, as well as their

\footnotetext{
${ }^{20}$ Susan Harris-Huemmert, Evaluating Evaluators: An Evaluation of Education in Germany (Wiesbaden: VS Verlag für Sozialwissenschaften, 2011), 30-31.

${ }^{21}$ Ibid., 31.

22 Ibid., 30. See also, Humboldt, “Internal and External Organization," 2.
} 


\section{A HUMBOLDTIAN CRITIQUE}

youthful energies and passions, to further and deepen their research and teaching functions. ${ }^{23}$

The third of the three unities mentioned by Humboldt is the unity of knowledge/science, represented by the lower side of the triangle. ${ }^{24}$ This unity implies that all the knowledge/sciences pursued and produced by the different faculties and departments within the university are expected to be noncontradictory with each other and will eventually form a coherent whole. ${ }^{25}$

Humboldt stipulated that freedom and solitude, represented by the circle that immediately contains the triangle of three unities, must prevail within the university. ${ }^{26}$ This freedom and solitude will provide an atmosphere that is conducive for the professors and students to go on with their unending quest for knowledge/science. Freedom inside the modern university is specifically articulated as the freedom to teach and do research on the part of the professor, and freedom to learn on the part of the students. The state, therefore, must give autonomy, represented by the upper right arrow in figure 1 , to the modern university. ${ }^{27}$ It must prevent the church from interfering in the affairs of the modern university. Humboldt observed that freedom could be under threat externally, as well as, internally. ${ }^{28} \mathrm{~A}$ similar case can be seen in the establishment of the Frankfurt School and the Institute of Social Research. Conceived by Felix Weil and funded by his father, Hermann Weil, the institute pursued, from the very beginning, an academic institution that is free from interference to pursue its goal of unrestricted social research and theoretical innovation. ${ }^{29}$

Since the modern research university is an expensive venture, the state, represented by the outermost concentric circle in figure 1, must be willing to shoulder its whole operation. ${ }^{30}$ To assure that this financial support will not deteriorate sooner or later into policy interference, Humboldt preferred that financial support is given as land grants, represented by the upper left arrow in figure 1, rather than annual budgetary allocation. ${ }^{31}$ The sufficient income from the land grants will allow the university to have short range and long range plans. Aside from the financial support, Humboldt

\footnotetext{
${ }^{23}$ Humboldt, "Internal and External Organization," 5.

${ }^{24}$ Harris-Huemmert, Evaluating Evaluators, 31.

${ }^{25}$ Ibid.

${ }^{26}$ Humboldt, "Internal and External Organization," 1.

${ }^{27}$ Ibid.

${ }^{28}$ Ibid., 3.

${ }^{29}$ Martin Jay, Dialectical Imagination: A History of the Frankfurt School and the Institute of Social Research 1923-1950 (London: Heinemann Educational Books, 1976), 5.

${ }^{30}$ John Hargrove Van de Graaff, The Politics of German University Reform, 1819-1979

${ }^{31}$ Ibid.
}

(New York: Columbia University, 1973), 36.

(c) 2018 F.P.A. Demeterio III and Roland Theuas DS. Pada

https://www.kritike.org/journal/issue 23/demeterio\&pada december2018.pdf

ISSN 1908-7330

(c) BY-NC-ND 
expects the state to also monitor the university to prevent its institutional structure from deteriorating through time. ${ }^{32}$ Humboldt is particularly concerned with the recruitment of professors. If the modern university is left alone to recruit its professors, it could easily engage in nepotism and favoritism, just like what happened to the traditional and medieval universities. ${ }^{33}$ Humboldt is particularly concerned as well with the possibility that the university itself, or its senior professors, will suppress the freedom of the other entities within the university. ${ }^{34}$

After all the trouble of putting up the modern research university, providing it with autonomy and land grants, as well as monitoring its continued institutional integrity, the state will finally reap its gains and rewards. The modern university provides the state with knowledge/science that it needs to fuel its socio-economic and cultural progress, represented by the lower left arrow in figure 1.35 The modern university also provides the state with superior and intelligent citizens, represented by the lower right arrow in figure 1, who will work for the state's progress and development. ${ }^{36}$ Humboldt emphasized that the modern university and the state may disagree on some short-term issues, but in the end, the goals of the state and the goals of the university are one and the same: progress and development. ${ }^{37}$ This could be the fourth unity in the Humboldtian university. Humboldt believes that the research/education received by the students in the modern university would eventually provide them with the formation/cultivation (Bildung) that they will need as cultured and dedicated citizens of the state: "for only the science that comes from the inside and can be implanted into the inside also reshapes the character, and the state, just as humanity is not concerned with knowledge and talk, but with character and action." 38

\section{Rationalization of the Prussian Educational System}

Humboldt did not only focus his philosophy of education on reforming the traditional and medieval university into a modern university. He also rationalized the diverse and unrelated learning institutions that were found in many German cities and states, specifically: the primary schools; secondary schools; universities; specialized schools that were providing educational trainings in veterinary medicine, mining, trade, agriculture, and

\footnotetext{
${ }^{32}$ Humboldt, "Internal and External Organization," 2.

${ }^{33}$ Ibid., 5.

${ }^{34}$ Ibid., 3.

35 Wellmon, Organizing Enlightenment, 226.

${ }^{36}$ Ibid., 217.

${ }^{37}$ Humboldt, "Internal and External Organization," 4.

${ }^{38}$ Ibid., 3.
}

(c) 2018 F.P.A. Demeterio III and Roland Theuas DS. Pada https://www.kritike.org/journal/issue 23/demeterio\&pada december2018.pdf ISSN 1908-7330 


\section{A HUMBOLDTIAN CRITIQUE}

others; academies, anatomical theatres, libraries, museums, menageries, and botanical gardens. ${ }^{39}$ Figure 2 represents how Humboldt rationalized and interlocked these various learning institutions into a single Prussian educational system.

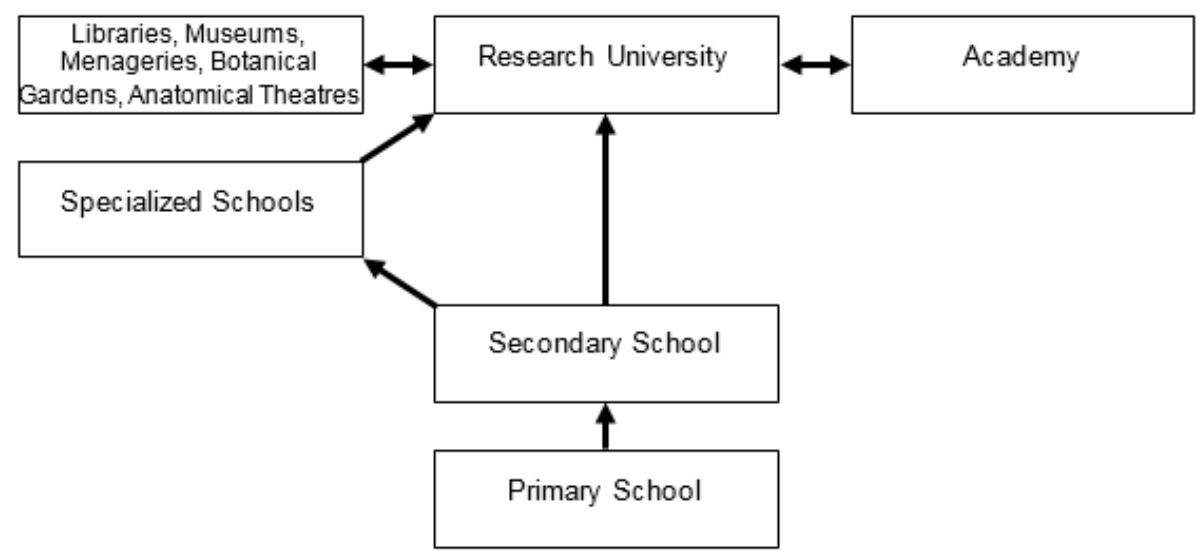

Figure 2: Humboldt's Interlocking of the Various Learning Institutions of Prussia into a Unified Prussian Educational System

Within the single Prussian educational system, curricular overlapping is avoided, and the lower or minor institutions of learning were made preparatory institutions or support institutions for the higher institutions of learning. Thus, the primary schools are expected to provide the fundamentals of learning that is necessary for the secondary schools. The secondary schools, in turn, provide broad general knowledge/science in preparation for the specialized fields in the specialized schools or the modern university. In the secondary schools, knowledge/science can remain as traditionally conceived: made and complete. ${ }^{40}$ Liberal education also happens in secondary schools. This will free a lot of time for the specialized knowledge/sciences in specialized schools and the modern university. Secondary education is very important for Humboldt to the point that he stipulated that only individuals who had university training should be allowed to teach in the secondary schools.

The specialized schools may be absorbed by the modern university. If it remains independent from the modern university, it can only provide training for specific skills (Erziehung) and not the superior

\footnotetext{
${ }^{39}$ Van de Graaff, The Politics of German University Reform, 30-31.

${ }^{40}$ Humboldt, "Internal and External Organization," 1.
} 
formation/cultivation (Bildung) provided by the modern university. ${ }^{41}$ The libraries, museums, anatomical theatres, menageries, and botanical gardens were brought closer to the university as additional venues for learning and research for both the professors and students, although these remained to be in the control of the state. ${ }^{42}$ The academy, previously the site of serious research, was also brought closer to the university. Humboldt believed that eventually, the modern university will eclipse the significance of the royal academy in terms of doing research because research in the modern university is continuous and efficient since it uses the intellectual powers and passions of the professors, but more so, the intellectual powers and passions of the stream of students. ${ }^{43}$

\section{Overview of the Humboldtian Educational Revolution}

With Humboldt's creation of the modern university, or his reformation of the traditional and medieval university, as well as his rationalization of the previously diverse and unrelated learning institutions within the German cities and states, he was able to successfully address the concrete and historical conditions that begged for a much-needed reformation. The Prussian government responded to the clamor for sociopolitical and cultural reforms of the humiliated and defeated Prussians through the establishment of the modern university.

The mercantilist orientation of pursuing research in the German universities was supplanted with a nobler orientation for research. Hence, instead of simply pressuring the professors to do research to increase the fame of their respective universities and contribute to the income of their respective cities and states, research became a pedagogical method that in the end would provide formation/cultivation (Bildung) to the students and sociopolitical and cultural progress to the state.

The tension between the teaching and research functions of the professors that arose from the financial allure of research was erased with the unification of teaching and research in the modern university. Theoretically speaking, the proverbial good researcher but the bad teacher and the good teacher but bad researcher could no longer thrive in the modern university since research became the way of teaching and teaching became part of research. The fear among traditional and medieval universities, as well as among professors, that the proliferation of books would eventually become their less expensive replacements is dispelled in Humboldt's philosophy of education. Books can only transmit made and complete knowledge and can

\footnotetext{
${ }^{41}$ Wellmon, Organizing Enlightenment, 217.

${ }^{42}$ Klencke and Schlesier, Lives of the Brothers Humboldt, 362.

${ }^{43}$ Humboldt, "Internal and External Organization," 5.
}

(c) 2018 F.P.A. Demeterio III and Roland Theuas DS. Pada https://www.kritike.org/journal/issue 23/demeterio\&pada december2018.pdf ISSN 1908-7330 


\section{A HUMBOLDTIAN CRITIQUE}

never compete with the modern university and its professors' capacity to handle knowledge as something that is always in the process of becoming.

The emerging concept of knowledge as something that is always in the process of becoming and will never be complete was responded to by the modern university's unification of teaching and research. In the modern university, knowledge is no longer transmitted for the sake of transmission. Instead, knowledge is transmitted as seeds for the students to generate new knowledge. The more pressing preoccupation in the modern university is to transmit to the students the skill of generating new knowledge. The German cities and states' diverse and unrelated learning institutions were rationalized and interlocked by Humboldt into a much stronger and efficient Prussian educational system.

The University of Berlin became the model of the modern university or more specifically the modern research university. The universities of Breslau and Bonn were the first ones to be established/reestablished after this model in 1811 and 1818, respectively. The model of the German research university achieved its definitive form at around 1830s and started to spread to the other German-speaking territories. ${ }^{44}$ In the early half of that same century, this model started to extend to the northern, eastern, and southern of Europe. ${ }^{45}$ Beyond Europe, the two countries that seriously pursued the model of the German research university were the United States of America and Japan. ${ }^{46}$

\section{American Translation of The Humboldtian Philosophy of Education}

From 1850 to 1870, American academics learned about the educational revolution that happened in Germany. ${ }^{47}$ Thousands of them went to Germany to obtain their doctor's degrees in the famed German universities, such as those of Berlin, Heidelberg, Leipzig, and Göttingen. ${ }^{48}$ Of

\footnotetext{
${ }^{44}$ William Clark, Academic Charisma and the Origins of the Research University (Chicago: University of Chicago Press, 2006), 28.

45 Ibid., 28.

${ }^{46}$ Altbach, "The Past, Present, and Future of the Research University," 15.

${ }^{47}$ Fallon, "German Influences on American Education," 85.

${ }^{48}$ Frank Trommler, "Recovering the History of Germanics in the United States: An Exploration," in Teaching German in Twentieth-Century America, ed. by David Benseler, Craig Nickisch, and Cora Lee Nollendorfs (Madison, WI: University of Winconsin Press, 2001), 28. See also Cameron Fincher, The Influence of British and German Universities on the Historical Development of American Universities (Athens, Georgia: Institute of Higher Education, University of Georgia, 1996), 4.

(c) 2018 F.P.A. Demeterio III and Roland Theuas DS. Pada

https://www.kritike.org/journal/issue 23/demeterio\&pada december2018.pdf

ISSN 1908-7330

(cc) BY-NC-ND
} 
these thousands of American academics, about 5,000 specifically studied at the University of Berlin. ${ }^{49}$

From 1869 to 1909, Charles William Eliot, who studied at the Marburg University, served as the president of Harvard University and led its transition from Harvard College to the leading American research university. In 1876, the Johns Hopkins University opened under the leadership of Daniel Coit Gilman, who studied at the University of Berlin. Johns Hopkins University was explicitly modelled after the German research university and became the first modern university in America and the first to offer graduate studies. ${ }^{50}$ In 1885, the Stanford University was founded. Of its original 30 professors, half earned their degrees in Germany. Its original logo even bore a German motto: Luft der Freiheit weht (the wind of freedom blows). In 1887, the Clark University was established under the leadership of Granville Stanley Hall, who studied further at the University of Berlin. To focus on research, Clark University started as a purely graduate-level university. It, however, opened its undergraduate programs more than a decade after. In 1890, the University of Chicago was founded under the leadership of William Rainey Harper. The University of Chicago made the innovation of retaining its undergraduate program as an English style college while modelling its graduate program on the German research university.

The American rendition of the Humboldtian model of the research university was supported by three landmark laws: the Morrill Act of 1862, the Hatch Act of 1887, and the Smith-Lever Act of 1914. ${ }^{51}$ Justin Smith Morrill, Senator from the State of Vermont, was the one who introduced the bill that would later be known as the Morrill Act of 1862. The act was intended to create land-grant colleges for the purpose of teaching "such branches of learning as are related to agriculture and the mechanic arts" but "without excluding other scientific and classical studies and including military tactic" so as "to promote the liberal and practical education of the industrial classes in the several pursuits and professions in life." 52 William Henry Hatch, Congressman from the State of Missouri, was the chairman of the house committee on agriculture when the bill that would later be known as the Hatch Act of 1887 was introduced. The act intended to provide federal funding to the land-grant colleges for them to establish agricultural experiment stations. The act, although limited to agriculture and its allied disciplines, could be considered as the legislated marker of the emergence of the American research universities. Michael Hoke Smith, Senator from the State of Georgia, and Asbury Francis Lever, Congressman from South

\footnotetext{
${ }^{49}$ Fincher, Influence of British and German Universities, 4.

${ }^{50}$ Ibid., 10.

51 Ibid.

${ }^{52}$ Morrill Act of 1862, 7 U.S.C. $§ 304$ (1862).
}

(c) 2018 F.P.A. Demeterio III and Roland Theuas DS. Pada https://www.kritike.org/journal/issue 23/demeterio\&pada december2018.pdf ISSN 1908-7330 


\section{A HUMBOLDTIAN CRITIQUE}

Carolina, advocated for the bill that would later be known as the Smith-Lever Act of 1914. The act mandated the land-grant colleges and universities to conduct extension services to disseminate information about innovations in "agriculture, uses of solar energy with respect to agriculture, home economics, and rural energy, and to encourage the application of the same." 53 If in the Humboldtian model of the research university extension is more like a tacit concept that undergirds the unity of goals of the state and the university, in the American model this is something that is made explicit by a legislation.

Roger Geiger's book To Advance Knowledge: The Growth of American Research Universities, 1900-1940, made the assertions that the American model of the research university's emphasis on the natural sciences became apparent in the 1850s, while its pursuance of utilitarian objectives became apparent in the 1860s. ${ }^{54}$ Thus, the Morrill Act of 1862, the Hatch Act of 1887, and the Smith-Lever Act of 1914 are more like the culmination of some trends that were going on in American higher education as America tried to appropriate the German model of the research university.

In the end, this was how the Americans translated the Humboldtian research university: the model was predominantly applied to graduate education in selected universities, while the American undergraduate education retained its old British model. ${ }^{55}$ Hence, the American model of the research university is a composite of a 17th-century British undergraduate base that supports a 19th-century Humboldtian graduate education. ${ }^{56}$ To energize this expensive model, the American research universities counted on expensive tuition fees, government endowments, private endowments, and further government grants. The Humboldtian unities of teaching and research, and of teachers and students were retained at the graduate level. The Humboldtian unity of the goals of state and university was highlighted with the American stress on extension programs. However, the Humboldtian unity of knowledge, that reserved a special place for philosophy, was set aside by the American fascination with utilitarian goals.

\footnotetext{
53 Smith-Lever Act of 1914, 7 U.S.C § 341 (1914).

${ }^{54}$ Roger Geiger, To Advance Knowledge: The Growth of American Research Universities, 1900-1940 (New York: Oxford University Press, 1986), 9.

${ }^{55}$ Fallon, "German Influences on American Education," 83. See also, Clark, Academic Charisma and the Origins of the Research University, 28. See also Fincher, Influence of British and German Universities, 1.

${ }^{56}$ Fallon, "German Influences on American Education," 83. See also Clark, Academic Charisma and the Origins of the Research University, 28.

(c) 2018 F.P.A. Demeterio III and Roland Theuas DS. Pada https://www.kritike.org/journal/issue 23/demeterio\&pada december2018.pdf ISSN 1908-7330
}

(c) BY-NC-ND 


\section{Critique of the University of The Philippines}

At its foundational stage, at least some people in UP were aware of the German and American research universities. Firstly, UP had a number of American professors who studied in either German or American research universities, such as Hans Aron (University of Berlin), Charles Fuller Baker (Stanford University), George William Beattie (University of California), Oliver Frederick Bishop (Yale University), William Hutchins Boynton (Cornell University), William Henry Brown (Cornell University), Edwin Bingham Copeland (Stanford University and the University of HalleWittenberg), Lawrence Edmonds Griffin (Johns Hopkins University), Dean Spruill Fansler (Columbia University), Paul Casper Freer (University of Munich), Eustace Merchant (Cornell University), and Archibald Ward (Cornell University). Secondly, the German language was taught at the university, and at its Los Baños campus, two years of learning the language was a requirement in order for the agricultural students to access the scientific literature. This policy reveals the American fascination with the German research university. Thirdly, two early university presidents explicitly mentioned in their inaugural addresses that the German university is known for its emphasis on research. But is UP a research university worthy of the same title as its German and American counterparts?

As already implied in the introductory section of this paper, such question will be covered by first periodizing UP into 1) its American colonial phase (1908-1946), 2) its liberation phase (1946-1972), 3) its system phase (1972-2008), and 4) its transition phase into a research university (2008present).

\section{The University During the American Colonial Period}

As already mentioned, this period spanned from 1908, the foundation of UP, to 1946, the end of the American colonial rule in the Philippines. The length of this period is 38 years. The key documents that were analyzed under the American colonial period of UP are: 1) the 1908 University Charter, or the Philippine Legislature Act Number 1870; 2) the inaugural speech of University President Murray Bartlett of 1911;3) the inaugural speech of University President Ignacio Villamor of 1915; 4) the inaugural speech of University President Guy Potter Benton of 1921; 5) the inaugural speech of University President Rafael Palma of 1925; 6) the Monroe Commission Report, otherwise known as A Survey of the Educational System of the Philippine Islands by the Board of Educational Survey, Created under Acts 3162 and 3196 of the Philippine Legislature, of 1925; 7) Encarnacion Alzona's book $A$ History of Education in the Philippines, 1565-1930 of 1932; 8) the inaugural 


\section{A HUMBOLDTIAN CRITIQUE}

speech of University President Jorge Bocobo of 1934; and 9) the inaugural speech of University President Bienvenido Gonzalez of 1939.

The 1908 University Charter (Act No. 1870): The foundational legislation of UP does not mention research. It states that the purpose of the university is: "to provide advanced instruction in literature, philosophy, the sciences, and arts, and to give professional and technical training." 57 Research, however, is hinted very faintly in its order for the university to establish endowed chairs in the colleges, and for the other government departments to lend and detail equipment, supplies and personnel to the university when needed. ${ }^{58}$ As it is, the foundational legislation of UP talks about a teaching university and not a research university.

The 1911 Inaugural Speech of Bartlett: Murray Bartlett was president of the university from 1911 to 1915. Research for him is a way of enriching classroom instruction:

undoubtedly in this university, there must be room, time, and provision for research. It would not make for efficiency if the professors spent all his time in teaching. He must keep abreast and ahead of his subject. He must inspire and enliven his instruction with inspiration gained from his own investigation. Only so can the student catch the spirit of initiative that is so necessary for the efficient worker in any field. ${ }^{59}$

The president was talking about a teaching university that should be enriched with research. He maintained the dichotomy between teaching and research.

The 1915 Inaugural Speech of Villamor: Ignacio Villamor was president of the university from 1915 to 1920 . He talked about research as something necessary for the sociopolitical, economic, and cultural development of the Philippines: "we should search the bowels of the earth to unfold its hidden treasures. We should transform raw materials to increase their commercial value. Science, in its various aspects, renders almost unlimited the power of the human efforts." 60 But he is not very clear about how this task is to be accomplished by the professors and students. His

\footnotetext{
${ }^{57}$ Act No. 1870, Sec. 2 (1908).

${ }^{58}$ Ibid., Sec. 6(d) and Sec. 14.

${ }^{59}$ Murray Bartlett, "A University for the Filipino," in The Role and Mission of the University: Inaugural Addresses of the Presidents of the University of the Philippines, ed. Consuelo Fonacier (Quezon City: University of the Philippines Press, 1971), 8.

${ }^{60}$ Ignacio Villamor, "The University and the People," in The Role and Mission of the University: Inaugural Addresses of the Presidents of the University of the Philippines, 25.

(c) 2018 F.P.A. Demeterio III and Roland Theuas DS. Pada https://www.kritike.org/journal/issue 23/demeterio\&pada december2018.pdf ISSN 1908-7330
}

(cc) BY-NC-ND 
statement appears like a mere lip service to the significance of research in the university.

The 1921 Inaugural Speech of Benton: Guy Potter Benton was president of the university from 1921 to 1925 . He wanted to limit the number of students to a realistically manageable group to allow the university to pursue excellence with its limited annual allocation. Research for him is still a way of enriching classroom instruction:

the best university instruction comes from the professor fresh from his investigations in the laboratory, and the research scientist finds the best confirmation of his conclusions by their application with his students in the classroom or lecture hall. The university teacher, without research habit, is dead on his feet, and the scientific investigator who does not teach is usually an impractical theorist. ${ }^{61}$

The president was again talking about a teaching university that should be enriched with research. He also maintained the dichotomy between teaching and research.

The 1925 Inaugural Speech of Palma: Rafael Palma was president of the university from 1925 to 1933 . His inaugural speech has no clear discussion on research at the university. But in his problematization on how to finance the developments in the university, he mentioned about his desire to ask the federal government itself, in Washington, D.C., to extend the benefits of the Hatch Act of 1887, the Adams Act of 1906, and the Smith-Lever Act of 1914 to UP as a publicly-funded university under the American colonial rule. ${ }^{62}$ The Hatch Act of 1887 and the Smith-Lever Act of 1914 were already mentioned as two of the three landmark laws that supported the American translation of the Humboldtian model of the research university. The Adams Act of 1906 is another legislation intended to further increase the federal funding to landgrant colleges and universities. Palma's intention to lobby in Washington, D.C. revealed the tacit understanding that the American government simply did not consider UP as one of its land-grant research colleges/universities.

The 1925 Monroe Commission Report: The Philippine Legislature authorized a 23-member team of American and Filipino educators to review the then two-decade-old American education implanted on the Philippine

\footnotetext{
${ }^{61}$ Guy Potter Benton, "Objectives of the University," in The Role and Mission of the University: Inaugural Addresses of the Presidents of the University of the Philippines, 48-49.

${ }^{62}$ Rafael Palma, "Inaugural Address," in The Role and Mission of the University: Inaugural Addresses of the Presidents of the University of the Philippines, ed. Consuelo Fonacier (Quezon City: University of the Philippines Press, 1971), 72.
}

(C) 2018 F.P.A. Demeterio III and Roland Theuas DS. Pada https://www.kritike.org/journal/issue 23/demeterio\&pada december2018.pdf ISSN 1908-7330 


\section{A HUMBOLDTIAN CRITIQUE}

soil. The head of the team was Paul Monroe, who at that time was the director of the International Institute of Teacher's College at the Columbia University. The eighth chapter of the team's report zeroed in on UP. This chapter is not only longer than any of the first five documents examined by this subsection, but its tone is also incisive and diagnostic instead of being futuristic and laudatory like the said first five documents.

The chapter mentions not less than ten phenomena that hindered the university's transition to a research university or at least its desire to strengthen its research capability. First is the incongruence between the Filipino-Spanish educational system and the American educational system. In the Filipino-Spanish educational system, the freshmen are younger than their American counterparts, and these younger freshmen were first required to take a two-year bachelor's degree program before they proceed to another two-year professional degree program. It was only in 1919 that UP discarded the two-year bachelor's degree training so that the freshmen can go directly to their professional degree training just like their American counterparts. ${ }^{63}$ However, UP was not able to address the fact that its freshmen were younger and therefore less intellectually mature than their American counterparts.

Second is the language gap between the English medium of the university and the Filipinos who were just recently trying to master the language of their new colonizers. ${ }^{64}$ If teaching these Filipino students was already a big challenge for the academic staff, it would be much more challenging to do meaningful research with them. The third is the meddling of the Filipino politicians with the governance of the university. The report emphasized: "in all political affairs and in all activities of the politicians, considerations of expediency and policy and even of partisanship and propaganda are bound to be influential." 65 Fourth is the rapid increase of the university's student population, which from 1911 to 1924 registered an average annual increase of $13.53 \% .{ }^{66}$ The report explained: "Unfortunately, when we come to the section entitled Income of the University, we shall see that the support necessary for efficient administration has not by any means kept with an increase in numbers." ${ }^{67}$ A rapidly growing university that can hardly support itself as a teaching university could not be expected to transition into a much more expensive research university.

\footnotetext{
${ }^{63}$ Paul Monroe, A Survey of the Educational System of the Philippine Islands by the Board of Educational Survey, Created under Acts 3162 and 3196 of the Philippine Legislature (Manila: Bureau of Printing, 1925), 610.

${ }^{64}$ Ibid.

65 Ibid., 613.

${ }^{66}$ Ibid., 616.

${ }^{67}$ Ibid., 617.

(c) 2018 F.P.A. Demeterio III and Roland Theuas DS. Pada https://www.kritike.org/journal/issue 23/demeterio\&pada december2018.pdf ISSN 1908-7330
}

(c) BY-NC-ND 
Fifth is the failure of the Philippine Legislature to petition the federal government to make UP a beneficiary of the Hatch Act of 1887, the Adams Act of 1906, and the Smith-Lever Act of 1914. ${ }^{68}$ The data gathering interviews of Monroe's team with the officials of UP could be what triggered Palma to articulate his desire to bring such petition to Washington, D.C. Sixth is the deplorable condition of the collection of the university library which the report labelled as "the weakest division of the University." 69 In the age prior to the internet, it is not right to expect quality research from both faculty and students when the library is below standard. Seventh is the heavy workload of the faculty members and their lack of resources that prevented them from producing quality output despite the abundance of potential research problems and topics in the Philippine setting and despite the talents and capacities of these faculty members. ${ }^{70}$ Eighth is the archipelagic geography of the Philippines and the average literacy and scientific readiness of the Filipinos that would make the extension more challenging. ${ }^{71}$

Ninth is the unreadiness of the university to establish a researchbased graduate school. The report explained: "no department of a university is costlier than a graduate school requiring as it does special laboratory and library facilities and personnel of unusual attainments - another matter of expense. UP is a young institution whose foundations need strengthening. Its limited resources should be concentrated on improving the work in which it is already engaged." 72 The tenth is the age demography of the faculty members, where $82 \%$ is below 40 years old. The report stated: "the comparative youth of the teaching staff is no doubt also the explanation of its relative sterility in scholarly productivity." 73 Added to this phenomenon that a huge portion of faculty members are part-time lecturers and teaching assistants. ${ }^{74}$ This demographic flaw is an outcome of the rapid increase of student numbers.

The 1932 History of Philippine Education of Alzona: The sixteenth chapter of Alzona's book focused on UP. This chapter is also longer than any of the inaugural speeches of the University Presidents, although its tone is not as incisive and diagnostic, compared to the Monroe Commission Report. The chapter mentions not less than five phenomena that have bearing to research. First is the explication that research has become part of the faculty

\footnotetext{
${ }^{68}$ Ibid., 629.

${ }^{69}$ Ibid., 643.

${ }^{70}$ Ibid., $645-645$.

${ }^{71}$ Ibid., 645 .

72 Ibid.

${ }^{73}$ Ibid., 654 .

${ }^{74}$ Ibid., 655
}

(c) 2018 F.P.A. Demeterio III and Roland Theuas DS. Pada https://www.kritike.org/journal/issue 23/demeterio\&pada december2018.pdf ISSN 1908-7330 


\section{A HUMBOLDTIAN CRITIQUE}

members' promotion in rank. ${ }^{75}$ Second is a reduction of the faculty members' teaching loads to 15 hours a week, which according to Alzona is "the current. . p practice in many American state universities." 76 The third is the decrease in the percentage of average annual increase in student numbers. If the Monroe Commission Report recorded an average annual increase of $13.53 \%$ from 1911 to 1924, Alzona only recorded an average annual increase of $4.87 \%$ from 1924 to $1930 .{ }^{77}$ But the trend was still about the annual increase in student numbers.

Fourth is the provision of a ten thousand-hectare land grant to UP, through the efforts of Palma and through the Act No. 3608 of 1930.78 However, the grant was not only two thousand hectares smaller than what was guaranteed by the Morrill Act of 1862, but it was also not meant to be sold but to be managed agriculturally or commercially. ${ }^{79}$ The Morrill Act of 1862 specified that the land should be sold and the proceeds are made into a trust fund for a given state college/university. ${ }^{80}$ Hence the land grant given to UP was not only smaller for a university that was growing bigger and bigger, but also created another managerial and entrepreneurial concern for the university. Nevertheless, Alzona saw it as "a beginning...to endow the university with a dependable source of income." ${ }^{81}$ Fifth is the reference to a partially centralized graduate programs for the Colleges of Liberal Arts, Education, and Agriculture, where such program remained non-researchbased and limited still to the masteral level. ${ }^{82}$ As a whole, although the sixteenth chapter of Alzona's book talks about favorable developments that strengthen research at UP, it also implies that the university was still unable to transition into a research university.

The 1934 Inaugural Speech of Bocobo: Dr. Jorge Bocobo was president of the university from 1934 to 1939. In his inaugural speech, he lamented the $45 \%$ reduction of the 1935 university budget with reference to the 1931 university budget. ${ }^{83} \mathrm{He}$ mentioned that such reduction put on hold some 500 research projects, of which $65 \%$ were supposed to be done in the College of Agriculture. ${ }^{84}$ With regard to the necessity of pursuing research,

75 Encarnacion Alzona, A History of Education in the Philippines, 1565-1930 (Manila: University of the Philippines Press, 1932), 280.

76 Ibid., 281-282.

77 Ibid., p.286.

${ }^{78}$ Ibid., p.292.

${ }^{79}$ Act No. 3608, Sec.3 (1930).

${ }^{80}$ Morrill Act of 1862, 7 U.S.C. $\S 304$ (1862).

${ }^{81}$ Ibid.

82 Ibid., 327-328.

83 Jorge Bocobo, "Presidential Inaugural Address," in The Role and Mission of the University: Inaugural Addresses of the Presidents of the University of the Philippines, 102.

${ }^{84}$ Ibid., 103-104.

(c) 2018 F.P.A. Demeterio III and Roland Theuas DS. Pada

https://www.kritike.org/journal/issue 23/demeterio\&pada december2018.pdf ISSN 1908-7330

(c) $)$ BY-NC-ND 
he stated: "the teaching for scientific agriculture in the Philippines must rely chiefly on our own researches because of the peculiarity of local conditions. Though to a less degree, the same problem confronts medicine, law, business, education, engineering, and the social sciences in these islands." 85 For Bocobo, research may be a means of developing the Philippine society, but in the context of education, it remained as a tool of scrounging suitable teaching materials.

The 1939 Inaugural Speech of Gonzalez: Dr. Bienvenido Gonzalez, an agricultural scientist trained in Johns Hopkins University, was president of the university from 1939 to 1943, and from 1945 to 1951. From 1943 to 1945, the president was Dr. Antonio Sison. These two are considered as the wartime presidents of the university. In his first inaugural address, Gonzalez admitted that research is something "that has suffered from relative neglect." $86 \mathrm{He}$ argued that research in the university is something necessary for the Philippine society: "For our own (university) to carve for herself a position of leadership among our people, she must take upon herself the task of studying our problems systematically and as far back as necessary so that with proper understanding, and in the light of experience, solutions may be worked out." ${ }^{87}$ Gonzalez, however, is silent about the interrelationship between teaching and research.

Summation: The story of UP during its American colonial period appears to be a story of a teaching university that had some aspirations to transition into a research university in its graduate level or at least strengthen the research capacity of its faculty members. It was a university that was controlled by the Philippine Legislature, and it was obliged to take in an increasing number of students that was way beyond what its annual allocations can reasonably accommodate. When it was constructively critiqued by the Monroe Commission it appeared to have responded well, such that in the early 1930s Alzona was able to record remarkable gains towards the strengthening of faculty research. But during the presidencies of Bocobo and Gonzalez, such gains appeared to be eclipsed by the great depression that impacted the Philippines in the 1930s and 1940s. The university remained a teaching university with a huge undergraduate population and a small body of master's level, non-research-based graduate students. It also appears that in order to respond to the great depression, the large segment of the middle class employed in the civil service and schools

\footnotetext{
85 Ibid., 105

${ }^{86}$ Bienvenido Gonzalez, "A University for the Philippines," in The Role and Mission of the University: Inaugural Addresses of the Presidents of the University of the Philippines, 129.

${ }^{87}$ Ibid., 121.
}

(c) 2018 F.P.A. Demeterio III and Roland Theuas DS. Pada https://www.kritike.org/journal/issue 23/demeterio\&pada december2018.pdf ISSN 1908-7330 


\section{A HUMBOLDTIAN CRITIQUE}

had to experience a decline in promotions and funding. ${ }^{88}$ Furthermore, this decline led to the inability of new high school and college graduates to find employment, thus, the trend following this, lead to the influx of growth in the public teaching sector in 1937-1939. ${ }^{89}$ The American colonial period of UP was concluded with the devastation of the Manila and Los Baños campuses brought about by the Second World War.

(Continued in Part II)

Department of Filipino, De La Salle University, Philippines Department of Philosophy, University of Santo Tomas, Philippines

\section{References}

Abueva, Jose, Reinventing UP as the National University: Learning for Truth, Leadership, and Social Transformation (Quezon City: University of the Philippines, 2008).

Act No. 1870, An Act for the Purpose of Founding a University for the Philippine Islands, Giving It Corporate Existence, Providing for a Board of Regents, Defining the Board's Responsibilities and Duties, Providing Higher Professional Instruction, and for Other Purposes (1908).

Act No. 3608, An Act Endowing the University of the Philippines with Portions of Lands of the Public Domain for Additional Support and Maintenance, and for other Purposes (1930).

Adams Act of 1906, An Act to Provide for an Increased Annual Appropriation for Agricultural Experiment Stations and Regulating the Expenditure Thereof (1906).

Altbach, Philip, "The Past, Present, and Future of the Research University," in The Road to Academic Excellence: The Making of World-Class Research Universities, ed. by Philip Altbach and Jamil Salmi (Washington, D.C.: The World Bank, 2011).

Alzona, Encarnacion, A History of Education in the Philippines, 1565-1930 (Manila: University of the Philippines Press, 1932).

Bartlett, Murray, "A University for the Filipino," in The Role and Mission of the University: Inaugural Addresses of the Presidents of the University of the Philippines, ed. by Consuelo Fonacier (Quezon City: University of the Philippines Press, 1971).

Bauzon, Leslie, “Angara's Tough Minded Leadership: The Diamond Jubilee Highlighted by Reform of the University System," in University of the

88 Daniel F. Doeppers, "Metropolitan Manila in the Great Depression: Crisis for Whom?" The Journal of Asian Studies, 50:3 (August 1991), 516.

${ }^{89}$ Ibid., 517.

(c) 2018 F.P.A. Demeterio III and Roland Theuas DS. Pada

https://www.kritike.org/journal/issue 23/demeterio\&pada december2018.pdf

ISSN 1908-7330

(c) $\mathrm{BY}-\mathrm{NC}-\mathrm{ND}$ 
Philippines: The First 75 Years (1908-1983), ed. by Oscar Alfonso (Quezon City: University of the Philippines, 1985).

Benton, Guy Potter, "Objectives of the University," in The Role and Mission of the University: Inaugural Addresses of the Presidents of the University of the Philippines, ed. by Consuelo Fonacier (Quezon City: University of the Philippines Press, 1971).

Bocobo, Jorge, "Presidential Inaugural Address," in The Role and Mission of the University: Inaugural Addresses of the Presidents of the University of the Philippines, ed. by Consuelo Fonacier (Quezon City: University of the Philippines Press, 1971).

Carson, Arthur, Higher Education in the Philippines (Washington, D.C.: United States Printing Office, 1961).

Clark, William, Academic Charisma and the Origins of the Research University (Chicago: University of Chicago Press, 2006).

Concepcion, Danilo, "Redefining the Culture of the University of the Philippines: Honor and Excellence with Compassion," (Diliman, Quezon City: Office of the Secretary of the University, 2016), http://osu.up.edu.ph/wp-content/uploads/2016/09/VISION PROF.DANILO-L.-CONCEPCION.pdf, 30 July 2017.

Dhondt, Pieter, "Humboldt in Belgium: Rhetoric on the German University Model," The Humboldtian Tradition: Origins and Legacies, ed. by Peter Josephson, Thomas Karlsohn, and Johan Östling (Leiden: Brill Academic Publishers, 2014).

Doeppers, Daniel F, "Metropolitan Manila in the Great Depression: Crisis for Whom?" The Journal of Asian Studies, 50:3 (August 1991).

Dyde, Walter, A Report on Graduate Education in the Philippines (Quezon City: Graduate College of Education, University of the Philippines, 1962).

Education Division, USOM to the Philippines, A Report of a Decade of U.S. Assistance to Public Education in the Philippines: The 10th Milestone Manila 1962 (Manila: USOM to the Philippines, Agency for Internationl Development, 1961).

Endriga, Jose, "Corpuz and Soriano's Bifocal Administrations: Toward a Realignment of the Academe to National Realities under a Crisis Government," in University of the Philippines: The First 75 Years (19081983), ed. by Oscar Alfonso (Quezon City: University of the Philippines, 1985).

Evangelista, Oscar, "Lopez's Beleaguered Tenure: Barricades on Campus at the Peak of Student Discontent," University of the Philippines: The First 75 Years (1908-1983), ed. by Oscar Alfonso (Quezon City: University of the Philippines, 1985).

Fallon, Daniel, "German Influences on American Education," in The GermanAmerican Encounter: Conflict and Cooperation Between Two Cultures, ed.

(C) 2018 F.P.A. Demeterio III and Roland Theuas DS. Pada https://www.kritike.org/journal/issue 23/demeterio\&pada december2018.pdf ISSN 1908-7330 
104 A HUMBOLDTIAN CRITIQUE

by Frank Trommler \& Elliott Shore (New York: Berghahn Books, 2002).

Fincher, Cameron, The Influence of British and German Universities on the Historical Development of American Universities (Athens, Georgia: Institute of Higher Education, University of Georgia, 1996).

Fores-Ganzon, Guadalupe, "Research," in Reappraisal and Rededication: Papers and Proceedings, 1966 UP Faculty Conference, ed. by Hernando Abaya. (Quezon City: University of the Philippines, 1966).

Geiger, Roger, To Advance Knowledge: The Growth of American Research Universities, 1900-1940 (New York: Oxford University Press, 1986).

Gonzalez, Bienvenido, "A University for the Philippines," in The Role and Mission of the University: Inaugural Addresses of the Presidents of the University of the Philippines, ed. by Consuelo Fonacier (Quezon City: University of the Philippines Press, 1971).

Harris-Huemmert, Susan, Evaluating Evaluators: An Evaluation of Education in Germany (Wiesbaden: VS Verlag für Sozialwissenschaften, 2011).

Hatch Act of 1887, An Act to Establish Agricultural Experiment Stations in Connection with the Colleges Established in the Several States under the Provisions of an Act Approved July Second, Eighteen Hundred and Sixty-Two, and of the Acts Supplementary Thereto, 7 U.S.C. $\S$ 361 (1887).

von Humboldt, Wilhelm. "On the Internal and External Organization of the Higher Scientific Institutions in Berlin," in German History in Documents and Images, Vol. 1, From Absolutism to Napoleon (16481815), ed. by William Hagen (Washington, D.C.: German Historical Institute, n.d.), http://germanhistorydocs.ghidc.org/sub document.cfm?document id=3642, 30 July 2017.

Javier, Emil, "U.P. in the Service of the Nation: Recapturing the Sense of National Purpose," in The Investiture of Dr. Emil Q. Javier as Sixteenth President of the University of the Philippines (Quezon City: University of the Philippines, 1994).

Jay, Martin, Dialectical Imagination: A History of the Frankfurt School and the Institute of Social Research 1923-1950 (London: Heinemann Educational Books, 1976).

Josephson, Peter, "The Publication Mill: The Beginnings of Publication History as an Academic Merit in German Universities, 1750-1810," in The Humboldtian Tradition: Origins and Legacies, ed. by Peter Josephson, Thomas Karlsohn, and Johan Östling (Leiden: Brill Academic Publishers, 2014).

Klencke, Hermann, and Gustav Schlesier, Lives of the Brothers Humboldt, Alexander and William (London: Ingram, Cooke and Company, 1852).

(c) 2018 F.P.A. Demeterio III and Roland Theuas DS. Pada

https://www.kritike.org/journal/issue 23/demeterio\&pada december2018.pdf

ISSN 1908-7330

(cc) BY-NC-ND 
Liedman, Sven-Eric, "In Search of Isis: General Education in Germany and Sweden," in The European and American University Since 1800: Historical and Sociological Essays, ed. by Sheldon Rothblatt and Bjorn Wittrock (Cambridge: Cambridge University Press, 1993).

Lopez, Salvador, "The University as Social Critic and Agent of Change," in The Role and Mission of the University: Inaugural Addresses of the Presidents of the University of the Philippines, ed. by Consuelo Fonacier (Quezon City: University of the Philippines Press, 1971).

Monroe, Paul, A Survey of the Educational System of the Philippine Islands by the Board of Educational Survey, Created under Acts 3162 and 3196 of the Philippine Legislature (Manila: Bureau of Printing, 1925).

Morales, Alfredo, "Our Goal of Quality Education," in Reappraisal and Rededication: Papers and Proceedings, 1966 UP Faculty Conference, ed. by Hernando Abaya (Quezon City: University of the Philippines, 1966).

Morgan, Keith, "Where is von Humboldt's University Now?" in Research in Higher Education-Daigaku Ronshu, 42 (March 2011).

Morrill Act of 1862, An Act Donating Public Lands to the Several States and Territories which May Provide Colleges for the Benefit of Agriculture and the Mechanic Arts, 7 U.S.C. § 304-309 (1862).

Nemenzo, Francisco, UP into the 21st Century and other Essays (Quezon City: University of the Philippines Press, 2000).

Office of the President of the University of the Philippines, University of the Philippines Strategic Plan 2011-2017 (Quezon City: University of the Philippines, 2012).

Office of the Vice President for Academic Affairs of the University of the Philippines, Shaping our Institutional Future: A Statement on Faculty Tenure, Rank and Promotion (Quezon City: University of the Philippines, 2004).

Office of the Vice President for Academic Affairs of the University of the Philippines, A University of the Philippines Research Guidebook (Quezon City: University of the Philippines, 2015).

Palma, Rafael, "Inaugural Address," in The Role and Mission of the University: Inaugural Addresses of the Presidents of the University of the Philippines, ed. by Consuelo Fonacier (Quezon City: University of the Philippines Press, 1971).

Pascual, Alfredo, "President Pascual's Turnover Speech," in UP Newsletter: The University of the Philippines Newspaper, 32:2 (February 2011).

Peters, Michael. "On Narratives of Self-Formation and Education," Psychosociological Issues in Human Resource Management, 3:2 (2015).

Presidential Decree No. 58, Constituting the University of the Philippines at Los Banos, Granting It Full and Complete Autonomy, and Amending the Charter of the University of the Philippines (1972).

(C) 2018 F.P.A. Demeterio III and Roland Theuas DS. Pada

https://www.kritike.org/journal/issue 23/demeterio\&pada december2018.pdf

ISSN 1908-7330 
106 A HUMBOLDTIAN CRITIQUE

"QS University Rankings: Asia 2016," in QS Top Universities, https://www.topuniversities.com/university-rankings/asianuniversity-rankings/2016, 14 August 2017.

Republic Act 9500, An Act to Strengthen the University of the Philippines as the National University (2008).

Revised Code of the University of the Philippines (Diliman, Quezon City: U.P. Law Center, 1975), http://osu.up.edu.ph/wpcontent/uploads/2014/05/UNIVERSITY-CODE-1961 1.pdf, 30 July 2017.

Roman, Emerlinda, "The University of the Philippines: A National University in the 21st Century," in The University of the Philippines Gazette, 36:3 (July-September 2005).

Romulo, Carlos, "Toward the Best University for the Filipino," in The Role and Mission of the University: Inaugural Addresses of the Presidents of the University of the Philippines, ed. by Consuelo Fonacier (Quezon City: University of the Philippines Press, 1971).

Sinco, Vicente, "The University of the Philippines and its Mission," in The Role and Mission of the University: Inaugural Addresses of the Presidents of the University of the Philippines, ed. by Consuelo Fonacier (Quezon City: University of the Philippines Press, 1971).

Smith-Lever Act of 1914, An Act to Provide for Cooperative Agricultural Extension Work between the Agricultural Colleges in Several States Receiving the Benefits of an Act of Congress approved July Second, Eighteen Hundred and Sixty-Two, and of Acts Supplementary Thereto, and the United States Department of Agriculture, 7 U.S.C $\S$ 341-349 (1914).

Tan, Vidal, "The Role of our State University," in The Role and Mission of the University: Inaugural Addresses of the Presidents of the University of the Philippines. ed. by Consuelo Fonacier (Quezon City: University of the Philippines Press, 1971).

Trommler, Frank, "Recovering the History of Germanics in the United States: an Exploration," in Teaching German in Twentieth-Century America, ed. by David Benseler, Craig Nickisch, and Cora Lee Nollendorfs (Madison, WI: University of Wisconsin Press, 2001).

United States Office of Mission to the Philippines, The Tenth Milestone: A Report of a Decade of U.S. Assistance to Public Education in the Philippines, 1952-1962 (Manila: United States Office of Mission to the Philippines, Agency for International Development, 1962).

Valenzuela, Victor, "Graduate Education," in Reappraisal and Rededication: Papers and Proceedings, 1966 UP Faculty Conference, ed. by Hernando Abaya (Quezon City: University of the Philippines, 1966).

(c) 2018 F.P.A. Demeterio III and Roland Theuas DS. Pada https://www.kritike.org/journal/issue 23/demeterio\&pada december2018.pdf ISSN 1908-7330

(c) BY-NC-ND 
Van de Graaff, John Hargrove, The Politics of German University Reform, 18191979 (New York: Columbia University, 1973).

Villamor, Ignacio, "The University and the People," in The Role and Mission of the University: Inaugural Addresses of the Presidents of the University of the Philippines, ed. by Consuelo Fonacier (Quezon City: University of the Philippines Press, 1971).

Wellmon, Chad, Organizing Enlightenment: Information Overload and the Invention of the Modern Research University (Baltimore, MD: Johns Hopkins University Press, 2016).

Ziolkowski, Theodore, "The Nineteenth-Century German University and German Idealism," in Reexamining Academic Freedom in Religiously Affiliated Universities: Transcending Orthodoxies, ed. by Kenneth Garcia (Cham: Palgrave Macmillan, 2016). 
Article

\title{
Resolving the Gettier Problem in the Smith Case: The Donnellan Linguistic Approach
}

\section{Joseph Martin M. Jose Napoleon M. Mabaquiao, Jr.}

\begin{abstract}
In this paper, we contend that the "Smith case" in Gettier's attempt to refute the justified true belief (JTB) account of knowledge does not work. This is because the said case fails to satisfy the truth condition, and thus is not a case of JTB at all. We demonstrate this claim using the framework of Donnellan's distinction between the referential and attributive uses of definite descriptions. Accordingly, the truth value of Smith's proposition "The man who will get the job has ten coins in his pocket" partly depends on how Smith uses the definite description "the man who will get the job" when he utters the proposition. Since, upon uttering the proposition, Smith has in mind a particular individual, namely Jones, and not just whoever will fit the attribute specified in the definite description, Smith uses the definite description referentially. And so when it turns out that it is Smith who eventually gets the job, the definite description fails to refer to Jones as intended by Smith, thereby making Smith's proposition false. To think that Smith's proposition is still true, in this regard, is to use the definite description attributively - that it is about whoever will fit the definite description. Apparently, when Gettier claims that Smith's proposition is still true, to demonstrate that it is a case of JTB, he, in effect, imposes his attributive understanding of Smith's usage of the definite description on Smith's own epistemic situation.
\end{abstract}

Keywords: Gettier, Donnellan, Gettier problem, definite descriptions

\section{Introduction}

ccording to the traditional understanding of knowledge (henceforth
understood as propositional knowledge ${ }^{1}$ ), knowledge is constituted by
three individually necessary and jointly sufficient conditions;

${ }^{1}$ Propositional knowledge is the kind of knowledge whose content is expressible in the form of a proposition and thus is truth-bearing. It is usually distinguished from practical knowledge, referring to knowledge of skills and procedures, and knowledge by acquaintance, referring to knowledge understood as familiarity with persons, places, and others. The contents of these two other kinds of knowledge are non-truth-bearing; that is, they cannot be said to be either true or false. The Gettier problem only concerns propositional knowledge.

(c) 2018 Joseph Martin M. Jose and Napoleon M. Mabaquiao, Jr. https://www.kritike.org/journal/issue 23/jose\&mabaquiao december2018.pdf ISSN 1908-7330 
namely: justification, truth, and belief. This understanding has been referred to as the Tripartite Analysis of Knowledge or the Justified True Belief (JTB) Account of Knowledge. Formally put, it claims that $S$ (standing for the subject) knows that $p$ (standing for any proposition) if and only if: (1) $S$ believes that $p ;(2) p$ is true; and (3) $S$ is justified in believing that $p$ is true. Throughout the history of philosophy, this account, it is safe to say, has been the long-held and accepted view by most analytic epistemologists. This, however, has been challenged by Edmund Gettier in his seminal paper "Is Justified True Belief Knowledge?" by presenting two cases (now called Gettier cases) which served as counterexamples to the JTB definition of knowledge. ${ }^{2}$ Gettier's critique can be summarized in the following argument:

P1: If JTB is a correct account of knowledge, then in all instances where JTB obtains, knowledge likewise obtains.

P2: There are instances where JTB obtains but knowledge does not obtain.

C: Therefore, JTB is not a correct account of knowledge.

Gettier's two cases are intended to instantiate P2. Different scholars, to defend the JTB account of knowledge, have used a variety of strategies to respond to the challenge of the Gettier cases. Jonathan Dancy distinguishes three general types of these strategies: "(1) find some means to show that the counterexamples do not work; (2) accept the counter-examples and search for a supplement to the tripartite analysis which excludes them; (3) accept the counter-examples and alter the tripartite analysis to suit rather than adding anything to it." 3 Most of the classical attempts to resolve the Gettier problem have focused on the strategy that seeks to modify certain aspects of the JTB account, either by adding supplementary conditions to the JTB conditions or by qualifying some or all of them to accommodate the Gettier cases. ${ }^{4}$ In our

\footnotetext{
${ }^{2}$ Edmund Gettier, “Is Justified True Belief Knowledge?,” Analysis, 23:6 (1963), 121-123.

${ }^{3}$ Jonathan Dancy, An Introduction to Contemporary Epistemology (Oxford: Blackwell Publishing, 1985), 26.

${ }^{4}$ Examples of attempts that have made use of this strategy include the following: the Infallibility Proposal which argues that we must make sure that in our cases of JTB one's justification for one's belief that p should be infallible [see Keith Lehrer, "Why Not Skepticism?," The Philosophical Forum, 2 (1971), 283-298, and Peter Unger, "A Defense of Skepticism," The Philosophical Review, 80:2 (1971), 198-219]; the Eliminating Luck Proposal which argues that we must remove any presence of luck in one's cases of JTB [see Peter Unger, "An Analysis of Factual Knowledge," Journal of Philosophy, 65:6 (1968), 157-170]; the No False Evidence Proposal which suggests that none of our evidence, by which we have a justified true belief, is false [see Richard Feldman, "An Alleged Defect in Gettier Counterexamples," Australasian Journal of Philosophy, 52 (1974), 68-69.]; the No Defeat Proposal which suggests that there be no defeaters in our evidences for having a justified true belief [see Keith Lehrer and Thomas Paxson, "Knowledge: Undefeated
} 


\section{RESOLVING THE GETTIER PROBLEM}

case, we shall endeavor to respond to the Gettier problem using the strategy that shows that the Gettier cases are problematic in themselves and that they do not work at all. We shall, however, focus only on the first Gettier case, known as the Smith case. We intend to demonstrate that this case is not a case of JTB at all and that there is a confusion in Gettier's understanding of Smith's epistemic situation. Crucial to our analysis is how Smith uses the definite description "the man who will get the job" upon uttering the proposition "The man who will get the job has ten coins in his pocket." The framework that we shall use for our analysis shall be Keith Donnellan's distinction between the referential and attributive uses of definite descriptions. Given this distinction, we shall argue that Gettier misunderstands Smith's epistemic situation with regard to the usage of the definite description in Smith's proposition. Basically, we contend that Smith is using the definite description referentially since he has a particular person in mind, namely, Jones, when he utters the proposition containing the definite description, and not whoever will fit the attribute indicated by the definite description. This means that Smith's proposition is false when in turns out that it is he, not Jones, who will get the job; and, consequently, fails to instantiate P2. To say that the proposition is still true, as Gettier does, is to wrongly impute an attributive usage to the definite description in Smith's proposition.

We shall divide our discussion into three parts. In the first part, we shall briefly expound on the JTB account of knowledge and present the Gettier problem as expressed in the first case. This will give us a better handle of the issue being addressed in the paper. In the second part, we shall provide a brief survey of the various approaches to the Gettier problem. This will distinguish our framework in handling the Gettier problem from the others. In the third part, we will explicate Donnellan's theory of definite descriptions and then apply this theory in resolving the Gettier problem in the Smith case.

Justified True Belief," Journal of Philosophy, 66:8 (1969), 225-237]; and the Appropriate Causality Proposal which suggests that $S^{\prime}$ s belief that $\mathrm{p}$ should be causally connected with $S^{\prime}$ s believing that p [see Alvin Goldman, "A Causal Theory of Knowing," Journal of Philosophy, 64:12 (1967), 357372]. Other attempts using other strategies include the following: the Competing Intuitions Approach, which point that there is a discrepancy between the intuitions of lay people and the intuitions of professional epistemologists; thus, posing problems on the interpretation of the Gettier cases itself [see Jonathan Weinberg, Shaun Nichols, and Stephen Stich, "Normativity and Epistemic Intuitions," Philosophical Topics, 29:1/2 (2001), 429-460]; and the Knowing Luckily Proposal which argues that although we cannot eliminate the presence of luck (strange occurrence/s) in some of our experiences of knowing, it does not diminish its status of being knowledge [see Stephen Hetherington, Good Knowledge, Bad Knowledge: On Two Dogmas of Epistemology (Oxford: Oxford University Press, 2000), 70-107].

(c) 2018 Joseph Martin M. Jose and Napoleon M. Mabaquiao, Jr. https://www.kritike.org/journal/issue 23/jose\&mabaquiao december2018.pdf ISSN 1908-7330

(cc) BY-NC-ND 


\section{JTB and Gettier's Smith Case}

As already noted, according to the JTB account of knowledge, knowledge consists of the three individually necessary and jointly sufficient conditions; namely: belief, truth, and justification. These three conditions are individually necessary for knowledge in that the absence of any of them would mean the absence of knowledge. They are, however, jointly sufficient in that the three of them together is enough to explain the occurrence of knowledge. To fully understand Gettier's critique of this account, let us briefly delve into each of the JTB conditions.

First, in order to say that we know that $p$, it is necessary that we believe that $p$. If we claim to know that Manila is the capital of the Philippines, for instance, it is necessary that we believe that Manila is the capital of the Philippines. What makes belief a necessary condition for knowledge can be explained via the Speech Act Theory developed by J.L. Austin and John Searle. ${ }^{5}$ For this theory, belief is the sincerity condition for assertives, the class of speech acts under which propositions are classified (along with descriptions, classifications, and explanations, among others). As Searle explains: "An assertive is always an expression of a belief." ${ }^{6}$ This means that we can only be said to be stating a proposition if at the time that we utter it our mental state or attitude towards the content of this proposition is one of belief. If we do not believe in the content of our proposition, our purpose for uttering the proposition is presumably other than to express a knowledge claim, say perhaps to mislead some people. For instance, if I believe that it is not raining and I tell a person that it is, my purpose in doing so is presumably not to tell

${ }^{5}$ Beliefs belong to what are called "intentional states" in the philosophy of mind, referring to a class of mental states whose mentality derives from their inherent directedness towards possible objects or states of affairs in the world. They are usually distinguished from the so-called "phenomenal states," whose mentality derives from their phenomenal feel or "what-itis-like" properties (paradigm examples are pains). When intentional states particularly concern possible states of affairs, they are usually called "propositional attitudes," a term coined by Bertrand Russell in consideration of their two main components: content and quality. Their content, which is expressible in the form of a proposition, refers to the possible state of affairs they are directed to; while their quality refers to their kind of attitude towards their content. Thus, "I believe that $\mathrm{p}$ " and "I hope that $\mathrm{p}$ " are propositional attitudes having two different attitudes towards the same content; whereas "I believe that $\mathrm{p}$ " and "I believe that $\mathrm{q}$ " are propositional attitudes having the same attitude towards different contents. Since the contents of propositional attitudes are either correct or incorrect representations of states of affairs in the world, they are thus truth-bearing, that is, they are either true or false. Now, the attitude of beliefs, in contrast to other propositional attitudes such as hopes, desires, and fears, is to assert the truth of their contents. See Napoleon Mabaquiao, Jr., Mind, Science and Computation (Quezon City: Vibal Publishing, Inc. and De La Salle University, 2012), 55-57.

${ }^{6}$ John Searle, Mind, Language and Society: Doing Philosophy in the Real World (London: Weidenfeld and Nicolson, 1999), 149.

(C) 2018 Joseph Martin M. Jose and Napoleon M. Mabaquiao, Jr. https://www.kritike.org/journal/issue 23/jose\&mabaquiao december2018.pdf ISSN 1908-7330 


\section{RESOLVING THE GETTIER PROBLEM}

this person what I know. In the language of Austin, my speech act in this situation is abused, and hence a failure (or "unhappy," as Austin puts it). ${ }^{7}$

The purpose of stating a proposition is to assert that something is the case; and we can only assert that something is the case if we believe it to be the case. This purpose is what Searle refers to as the illocutionary point of the assertive class: "The point of the assertive speech acts is to commit the hearer to the truth of the proposition. It is to present the proposition as representing a state of affairs." ${ }^{8}$ Belief is, therefore, necessary for knowledge, for it is a necessary condition (acting as the proposition's sincerity condition) for stating the proposition that one claims to know. But is belief sufficient for knowledge? No, for not all of our beliefs are true; and truth is also necessary for knowledge. If someone, for instance, claims to know that Earth has three moons or that 2 and 2 are 6 , we will surely respond that he/she does not really know what he/she is talking about, even though he/she believes them to be true. This is because we know that what he/she claims to know is false. For knowledge to obtain, one cannot just believe a proposition; rather, that proposition must also be true. Of course, there are various contending positions as to when one can legitimately say that a proposition is true. ${ }^{9}$ This, however, does not change the fact that truth, in addition to belief, is a necessary condition for knowledge.

So then, are belief and truth already sufficient for knowledge? Not yet. Consider the fact that one can form one's belief based on mere hunch or lucky guesses, which later on turns out to be true. ${ }^{10}$ An example is a belief that it is presently raining in another part of the country, which is based on reading a forecast of a fake news agency. Now suppose that it is actually raining in that part of the country, then one's belief is true even though one's belief is based on faulty grounds. But can we say that this person does indeed know that it is raining in another part of the country? No, for how we come to know the truth of our beliefs also matters. What we believe to be true must be based on good grounds, reasons, or evidences. These good grounds, reasons, and evidences upon which our belief of a true proposition must rest are what we call justification. Justification is thus the third necessary

\footnotetext{
${ }^{7}$ J.L. Austin, How to do Things with Words (Oxford: Oxford University Press, 1962), 12 24; and J.L. Austin, "Performative-Constative," in The Philosophy of Language, ed. by John Searle (Oxford: Oxford University Press, 1971), 13-22.

${ }^{8}$ Searle, Mind, Language and Society, 148.

${ }^{9}$ There are, for instance, the three main theories on truth, namely, the correspondence, coherence, and pragmatic theories of truth. In the main, the correspondence theory claims that $\mathrm{X}$ is true if and only if $X$ corresponds to facts (or states of affairs in the world); the coherence theory argues that $X$ is true if and only if $X$ coheres to a given set of propositions/beliefs; and the pragmatic theory states that $\mathrm{X}$ is true if and only if $\mathrm{X}$ is useful. See Noah Lemos, An Introduction to the Theory of Knowledge (Cambridge: Cambridge University Press, 2007), 9-12.

${ }^{10}$ Lemos, An Introduction to the Theory of Knowledge, 6.
}

(c) 2018 Joseph Martin M. Jose and Napoleon M. Mabaquiao, Jr. https://www.kritike.org/journal/issue 23/jose\&mabaquiao december2018.pdf ISSN 1908-7330

(c) BY-NC-ND 
condition for knowledge. To know that $p$, we should believe that $p$, $p$ must be true, and our belief that $p$ is true must be justified.

Now, the two Gettier cases are intended to serve as two counterexamples to the JTB account, whereby the three conditions are believed to have obtained and yet we cannot allegedly claim that knowledge has likewise obtained. For our purposes, we shall, however, focus only on the first case, as all of the other attempts to engage Donnellan's theory of definite descriptions only dealt with the first case. More importantly, it is because it is the first case that is directly open for linguistic analysis, for which Donnellan's theory is one strategy. As such, our conclusion will, therefore, also be limited only to the first case. Now whether our analysis of this first case extends to the second one is something that would require another research. Offhand, since the second Gettier case operates on strictly logical terms and rules, its analysis would require a strategy that is more logical rather than linguistic. In any case, before we present the first Gettier case, it is important to take note that Gettier has some assumptions in his critique of the JTB account. First, Gettier assumes that "it is possible for a person to be justified in believing a proposition that is in fact false."11 Second, Gettier subscribes to the Principle of Deductive Closure, 12 according to which: "for any proposition $P$, if $S$ is justified in believing $P$, and $P$ entails $Q$, and $S$ deduces $Q$ from $P$ and accepts $Q$ as a result of this deduction, then $S$ is justified in believing Q." ${ }^{13}$ In short, this principle tells us that justification can be transmitted via deduction from one proposition to another.

Gettier's first case asks us to suppose that two men, Smith and Jones, are applying for a certain job. ${ }^{14}$ While waiting, Smith is informed by the president of the company that Jones will be the one who will get the job. Furthermore, Smith earlier found out that Jones has ten coins in his pocket. From these two evidences, Smith formulates the conjunctive proposition that: (d) "Jones is the man who will get the job, and Jones has ten coins in his pocket." From this proposition, Smith deduces the proposition: (e) "The man who will get the job has ten coins in his pocket." Through the Principle of

${ }^{11}$ Gettier, “Is Justified True Belief Knowledge?," 121. Noah Lemos provides some illustrative examples: "Suppose, for example, you are justified in believing that it is noon. You are justified because you have just looked at your watch around midday and it says that it is noon. But suppose that, unbeknownst to you, your watch stopped working at noon and it is now 12:30. Given your evidence, your belief is justified but false. Again, I might be justified in believing that the person I see going into the library is Lisa. I am justified because the person I see looks, dresses, and behaves just like Lisa. But suppose that, unbeknownst to me, Lisa has an identical twin and the person I see is not Lisa, but her twin. My belief that the person I saw was Lisa is false, but justified." See Lemos, An Introduction to the Theory of Knowledge, 14.

12 Lemos, An Introduction to the Theory of Knowledge, 24-25.

${ }^{13}$ Gettier, "Is Justified True Belief Knowledge?," 121.

${ }^{14}$ Ibid., 122.

(C) 2018 Joseph Martin M. Jose and Napoleon M. Mabaquiao, Jr. https://www.kritike.org/journal/issue 23/jose\&mabaquiao december2018.pdf ISSN 1908-7330 


\section{RESOLVING THE GETTIER PROBLEM}

Deductive Closure, Smith is justified in believing that proposition (e) is true which he deduces from proposition (d), which in turn he is justified in believing based on the two evidences. But then Gettier further asks us to imagine that unknown to Smith, it is he who will get the job and that he himself has ten coins in his pocket. Gettier remarks:

Proposition (e) is then true, though proposition (d), from which Smith inferred proposition (e) is false. In our example, then, all of the following are true: (i) (e) is true, (ii) Smith believes that (e) is true, and (iii) Smith is justified in believing that (e) is true. But it is equally clear that Smith does not know that (e) is true; for (e) is true in virtue of the number of coins in Smith's pocket, while Smith does not know how many coins are in Smith's pocket, and bases his belief in (e) on a count of the coins in Jones's pocket, whom he falsely believes to be the man who will get the job. ${ }^{15}$

Throughout the decades after Gettier formulated his two cases, there are epistemologists who created their own "Gettier cases."16 For instance, Roderick Chisholm formulated his sheep in the field case wherein we are asked to imagine that a person, say Luke, is standing in front of a field and that in front of Luke there is a sheep. ${ }^{17}$ Luke then formulates the proposition, "There is a sheep in the field." But unknown to Luke, the sheep that he sees is not really a sheep but a dog disguised as a sheep. But also unknown to Luke, there is in fact a sheep in the field but hiding behind the hill in the field. Hence, Luke has a justified true belief that there is a sheep in the field. But can one say that Luke has indeed knowledge that there is a sheep in the field?

\section{Approaches to the Gettier Problem}

Following Allan Hazlett, the various attempts to respond to the Gettier problem can be divided into two periods: the $20^{\text {th }}$ century and the $21^{\text {st }}$

${ }^{15}$ Ibid.

${ }^{16}$ For our purposes, we will only discuss the sheep in the field case since that will only be the focus of our analysis later and that such a case is sufficient to show that our analysis later can, in a sense, be extended to other versions of the Gettier cases and not just limited to what Gettier originally formulated. For the other cases, see Brian Skyrms, "The Explication of ' $X$ knows that $\mathrm{p}^{\prime}$," Journal of Philosophy, 64 (1967), 373-389, for the pyromaniac case. And see Alvin Goldman, "Discrimination and Perceptual Knowledge," Journal of Philosophy, 73 (1976), 771-791, for the fake barns case.

${ }^{17}$ Roderick Chisholm, Theory of Knowledge (New Jersey: Prentice Hall, 1966), 23.

(c) 2018 Joseph Martin M. Jose and Napoleon M. Mabaquiao, Jr. https://www.kritike.org/journal/issue 23/jose\&mabaquiao december2018.pdf ISSN 1908-7330

$((c))$ BY-NC-ND 
century. ${ }^{18}$ The former is what epistemologists traditionally call the "postGettier period," referring to the first few decades of research done about the Gettier problem. Hazlett provides a succinct survey of this period:

Some (Clark 1963) argued that knowledge cannot be derived from a false premise; others (Lehrer and Paxson 1969) argued that knowledge requires indefeasible justification; others (Goldman 1967) argued that knowledge must be caused by the truth of the proposition known; others (Stine 1967; Goldman 1976; Dretske 1981, Chapter 4) argued that knowledge requires the elimination of relevant alternatives; others (Nozick 1981, Chap. 3; Sosa 1999; Williamson 2000) argued that knowledge requires sensitivity (that you would not believe that $p$, were it not true that $p$ ) or safety (that you would not easily believe falsely that $p$ ). Externalist theories of knowledge flourished during this period-where these are (roughly) those that allow necessary conditions on knowledge (apart from the truth condition) the obtaining of which may be (in some sense) inaccessible to the knower. ${ }^{19}$

As we can observe, the contending positions on how to properly resolve the Gettier problem during this period, as cited by Hazlett, all made use of the strategy whereby the conditions of knowledge are modified in order to accommodate the Gettier cases. There are, however, also approaches during this period that utilize the strategy whereby Gettier's assumptions are put into question. ${ }^{20}$ They include approaches that reject the Principle of Deductive Closure and the assumption that we can be justified in believing a false proposition.

On the other hand, the approaches of the $21^{\text {st }}$ century attempts are more eclectic. One approach questions the very source of the Gettier problem and the solubility of it. It argues, for instance, that the problem has something to do about the nature of luck and our assumptions about the nature of knowledge. ${ }^{21}$ Yet another approach employs metaphilosophical research methods to deal with the epistemological assumptions regarding our

${ }^{18}$ Allan Hazlett, "The Maturation of the Gettier Problem," Philosophical Studies, 172:1 (2015), 2-3.

19 Ibid., 2.

${ }^{20}$ Lemos, An Introduction to the Theory of Knowledge, 25-26.

21 See Linda Zagzebski, "The Inescapability of Gettier Problems," Philosophical Quarterly, 44:174 (1994), 65-75.

(c) 2018 Joseph Martin M. Jose and Napoleon M. Mabaquiao, Jr. https://www.kritike.org/journal/issue 23/jose\&mabaquiao december2018.pdf ISSN 1908-7330 


\section{RESOLVING THE GETTIER PROBLEM}

intuitions on what knowledge is. This approach involves the method of experimental philosophy in order to examine the nature and evidential status of philosophical intuitions. ${ }^{22}$ One notable finding in this approach is that the intuition that knowledge is not present in Gettier cases is only common among non-Asian people, which shows, among others, that there is a discrepancy between the intuitions of epistemologists and lay people, and among the intuitions of lay people of different contexts/backgrounds. ${ }^{23}$ Lastly, there are attempts in the $21^{\text {st }}$ century whose approaches go beyond the confines of epistemology, such as those which utilize theories about the nature of intentional action and luck. ${ }^{24}$ But one of the most promising approaches during this period is the one that aligns itself with the so-called "linguistic turn" in the analytic tradition, whereby philosophical issues are generally regarded as questions about language, or as arising from certain forms of linguistic confusion.

The linguistic approach to the Gettier problem makes use of the various theories of meaning in the (analytic) philosophy of language. A major criticism of the linguistic philosophers against the Gettier problem is that it exploits the principles of logic to argue for cases that may not or do not even happen in our ordinary everyday lives or arise from our linguistic expressions in our everyday communications. It further contends that the circumstances in the Gettier cases, along with their truth claims, are not how our epistemic situation works in everyday circumstances. In this regard, some linguistic philosophers argue that "the form of a statement alone does not provide sufficient basis for judging its truth in normal everyday discourse, that is, natural language, which happens to be the domain of the Gettier cases." ${ }^{25}$ For them, the exploitative use of logic as evidenced by the use of the Principle of Deductive Closure, Principle of Existential Generalization, and Principle of Disjunction Introduction ${ }^{26}$ have taken for granted the role that

\footnotetext{
${ }^{22}$ See Ernest Sosa, "Can there be a Discipline of Philosophy? And can it be Founded on Intuitions?," Mind and Language, 26:4 (2011), 453-467.

${ }^{23}$ See Joshua Knobe and Shaun Nichols, Experimental Philosophy (Oxford: Oxford University Press, 2008), and Weinberg, Nichols, and Stich, "Normativity and Epistemic Intuitions," 429-460.

24 See Duncan Pritchard, Epistemic Luck (Oxford: Oxford University Press, 2005). (2016), 453

25 Yussif Yakubu, "Truth Analysis of the Gettier Argument," Metaphilosophy, 47:3

${ }^{26}$ As a recap, the Principle of Deductive Closure states that "for any proposition $\mathrm{P}$, if $\mathrm{S}$ is justified in believing $\mathrm{P}$, and $\mathrm{P}$ entails $\mathrm{Q}$, and $\mathrm{S}$ deduces $\mathrm{Q}$ from $\mathrm{P}$ and accepts $\mathrm{Q}$ as a result of this deduction, then $\mathrm{S}$ is justified in believing Q" [see Gettier, "Is Justified True Belief Knowledge?" 121]. In short, this principle tells us that justification can be transmitted via deduction from one proposition to another. On the other hand, the Principle of Existential Generalization is "used to infer an existentially quantified formula from a formula which tells us something about some named individual .... For example, consider the simplest possible case of such an inference in natural language. Given 'Arlo Guthrie is a folk singer' I might go on to infer
}

(c) 2018 Joseph Martin M. Jose and Napoleon M. Mabaquiao, Jr. https://www.kritike.org/journal/issue 23/jose\&mabaquiao december2018.pdf ISSN 1908-7330

(c) $)$ BY-NC-ND 
content, context, state of mind, and other extralocutionary factors plays in making sense of the Gettier cases and of our epistemic situations in general. ${ }^{27}$ Such factors are all taken for granted in the epistemological discourse, leading epistemologists, arguably including Gettier, to overlook, if not forget, that natural language and classical logic have different ways of approaching truth. 28

Yussif Yakubu, in his article "Truth Analysis of the Gettier Argument," provides a preliminary sketch of how linguistic approaches to the Gettier problem may proceed in the future. He argues that "an analysis that incautiously deploys the tools of classical logic in evaluating the truth of propositions in practical discourse involving natural language courts error, and the Gettier cases involve analysis of this kind." ${ }^{29}$ He then proceeds to demonstrate such claim by making use of certain theories in the philosophy of language. These theories include P.F. Strawson's distinction of a sentence and a use of a sentence, Immanuel Kant's dichotomy of analytic and synthetic statements, Donnellan's referential and attributive uses of definite descriptions, analytic philosophy's de dicto and de re distinction, Saul Kripke's distinction between semantic reference and speaker's reference (in which Yakubu argues that Kripke's semantic reference parallels the conversational implicature of H.P. Grice), and the uniquely referring phrase of Strawson. ${ }^{30}$ With these various distinctions in our linguistic expressions in mind, Yakubu expects that the conflation of one concept/use/principle with another concept/use/principle in the Gettier cases which brings about the confusions in the Gettier problem will finally disappear. ${ }^{31}$ The linguistic approaches to the Gettier problem that Yakubu finds most promising are those that make use of Kripke's distinction between semantic reference and speaker's reference, and of Donnellan's distinction between the referential and attributive uses of definite descriptions.

One who endorses Kripke's semantic and speaker references as a linguistic approach to the Gettier problem is Moti Mizhari. Mizhari claims that the Gettier cases merely appear to be cases of epistemic failure, for they

'There exists at least one folk singer'." [see Paul Tomassi, Logic (London: Routledge, 1999), 281282]. Lastly, the Principle of Disjunction Introduction states that "given any formula on any line of proof, [such principle] allows us to infer immediately the disjunction of that formula with any other well-formed formula we care to choose. In other words, [it] allows us to take any formula from any line of proof, to write that formula on a new line together with ' $v$ ' and to complete the disjunction with absolutely any other well-formed formula we might like the look of." [see Tomassi, Logic, 83].

${ }^{27}$ Yakubu, "Truth Analysis of the Gettier Argument," 453.

${ }^{28}$ Ibid.

${ }^{29}$ Ibid., 465.

30 Ibid., 459 .

${ }^{31}$ Ibid., 455.

(C) 2018 Joseph Martin M. Jose and Napoleon M. Mabaquiao, Jr. https://www.kritike.org/journal/issue 23/jose\&mabaquiao december2018.pdf ISSN 1908-7330 


\section{RESOLVING THE GETTIER PROBLEM}

are actually cases of semantic failure caused by the presence of what Kripke calls "ambiguous designators." These designators make the Gettier cases misleading because there can be an ambiguity with regard to whether they employ speaker reference or semantic reference. ${ }^{32}$ Accordingly, the ambiguous designator at issue is the definite description "the man who will get the job." Its speaker reference is Jones, while its semantic reference is whoever will fit the description "the man who will get the job."

Yakubu, in his analysis, finds the linguistic approach based on Kripke's distinction similar in nature to Donnellan's: Kripke's semantic reference corresponds to Donnellan's attributive use; and Kripke's speaker's reference to Donnellan's referential use. ${ }^{33}$ According to Yakubu, using the framework of Donnellan's theory of definite description, what is ambiguous with regard to the said definite description is how it is used in the proposition "The man who will get the job has ten coins in his pocket," as uttered by Smith. ${ }^{34}$ Accordingly, Smith uses it referentially as Smith has Jones in mind, while Gettier understands its use in the attribute sense-that is, whoever fits the description specified by the definite description. For our purposes in this essay, we shall elaborate on the Donnellan linguistic approach to the Gettier problem. While we find Yakubu in the right direction in his own analysis of how the Donnellan linguistic approach will proceed in resolving the Gettier problem, he, however, does not delve into the details of this approach, as his main objective in his essay is simply to provide a preliminary sketch as to how a linguistic approach to the Gettier problem can be done. ${ }^{35}$ Our purpose then is to fill in what is lacking in Yakubu's account: ${ }^{36}$ we intend to provide

${ }^{32}$ Moti Mizhari, “Why Gettier Cases Are Misleading?” Logos E Episteme, 7:1 (2016), 31-

44.

${ }^{33}$ For further analysis of this point, see also Philip Atkins' reply to Mizhari's arguments. See Philip Atkins, “Are Gettier Cases Misleading?" Logos \& Episteme, 7:3 (2016), 379_ 384 .

${ }^{34}$ Yakubu, "Truth Analysis of the Gettier Argument," 457-458.

${ }^{35}$ It is interesting to note that Konstanz Christoph Schimdt-Petri also made use of Donnellan's distinction in arguing that Gettier's example is flawed. He provides both a referential and attributive reading of the cases. However, what makes his analysis different is that he argues that what is violated is the belief condition in the JTB, on the other hand, for our case and Yakubu's, it is the truth condition which is our concern. Thus, this paper will be explicating further such initiative. See Konstanz Christoph Schimdt-Petri, "Is Gettier's First Example Flawed?" in Knowledge and Belief, ed. by Winfried Loffler and Paul Weingartner (Austrian Ludwig Wittgenstein Society, 2003), 317-319.

${ }^{36}$ Furthermore, Yakubu claims that there are some versions of the Gettier cases that do not involve a definite description; hence, using Donnellan's theory of definite descriptions as a framework would not be applicable all the time [see Yakubu, "Truth Analysis of the Gettier Argument," 457]. However, we find that in so far as the existing Gettier cases in the literature are concerned, they contain a definite description although not explicitly stated. Hence, what is needed is to reword those Gettier cases in such a way that a definite description can be obviously seen. We have to remember that not all the succeeding versions of the original Gettier cases

(c) 2018 Joseph Martin M. Jose and Napoleon M. Mabaquiao, Jr. https://www.kritike.org/journal/issue 23/jose\&mabaquiao december2018.pdf ISSN 1908-7330

(cc) BY-NC-ND 
the necessary explanation for how the Donnellan linguistic approach can be used effectively in resolving, or dissolving, the Gettier problem as presented in the first case (the Smith case).

\section{The Donnellan Linguistic Strategy}

Donnellan, in his paper "Reference and Definite Descriptions," argues that definite descriptions (expressions that come in the form "the so and so") have two functions: attributive and referential. ${ }^{37}$ When someone uses a definite description attributively, he/she "states something about whoever or whatever is the so-and-so." 38 On the other hand, when someone uses a definite description referentially, he/she "uses the description to enable his audience to pick out whom or what he is talking about and states something about that person or thing." 39

In an assertion, when a definite description is used attributively such definite description functions as a sort of essence. It is because "one wishes to assert something about whatever or whoever fits that description." 40 Hence, the "attribute of being the so-and-so is all important." 41 On the other hand, when a definite description is used in an assertion referentially, such definite description is just one among many tools by which one can use in order to point out, pick out, or call to one's attention a person or thing which other linguistic devices/tools could perform as well. ${ }^{42}$ Hence, "the attribute of being the so-and-so is not important." ${ }^{43}$ To illustrate, let us consider an example

followed the format and wordings of Gettier in his paper. The sheep in the field, pyromaniac and fake barns cases are examples.

${ }^{37}$ Keith Donnellan's distinction between the attributive and referential uses of definite descriptions is a response to Bertrand Russell and P.F. Strawson's views on definite descriptions. One of the main contentions of Donnellan is that Russell and Strawson's view is incomplete in that their understanding of the function of definite descriptions is limited only in the attributive use; hence, making their theory incomplete. According to Donnellan, definite descriptions do not only have an attributive use; but also a referential use. In fairness to Russell, it is not really the case that Russell does not acknowledge the referential use of definite descriptions as used in ordinary language; what he simply claims is that in a logically perfect language, definite descriptions should only be used attributively for using it referentially will confuse it with the function of proper names. The importance of Donnellan's clarification of these two uses of definite descriptions in the context of ordinary language, however, goes beyond its being a critique of Russell's theory of definite descriptions, for being able to resolve certain linguistic puzzles.

${ }^{38}$ Keith Donnellan, "Reference and Definite Descriptions," The Philosophical Review, 75:3 (1966): 285.

${ }^{39}$ Ibid.

${ }^{40}$ Ibid.

${ }^{41}$ Ibid.

${ }^{42}$ Ibid.

${ }^{43}$ Ibid.

(C) 2018 Joseph Martin M. Jose and Napoleon M. Mabaquiao, Jr. https://www.kritike.org/journal/issue 23/jose\&mabaquiao december2018.pdf

ISSN 1908-7330 
given by Donnellan: the proposition "Smith's murderer is insane." 44 Imagine that Smith's good friend, Henry, comes across Smith's body on the road whose body parts are fragmented. Smith's head decapitated, the bones in his arms and legs protruding out of his skin. His clothes soaked in his own blood. All of this points to Smith being murdered in an unimaginable, heinous way. Henry then forms an assertion saying that "Smith's murderer is insane." Such an assertion contains a definite description, "the person who murdered Smith" here expressed simply as "Smith's murderer," which Donnellan says is used in the attributive sense, for Henry does not intend that his definite description be a tool to aid his audience to pick out whomever he is talking about. Rather, Henry uses it to say something about whoever satisfies such description (i.e., whoever murdered Smith is insane). Henry has no particular person in mind in making such an assertion, for he does not know who murdered Smith. Anyone who satisfies the description qualifies as that someone whom Henry is talking about.

On the other hand, consider the same assertion "Smith's murderer is insane," this time uttered by another good friend of Smith, Jack, while witnessing the trial of the person suspected to be Smith's murderer is being cross-examined. Let us suppose that this person is named Jones. Jack has known about the way his friend Smith has been murdered; and he is convinced that the person who did this was Jones. When Jack utters the assertion "Smith's murderer is insane," Jack uses the definite description "Smith's murderer" (or "the man who murdered Smith"), according to Donnellan, in the referential sense, for Jack is using the definite description to help the people around him pick out the person he is talking about. Now whether or not it is true that Jones is the murderer of Smith (in other words, whether Jones fits the description of the definite description) is not important because the definite description is only used as a tool to make the audience pick out what Jack is talking about.

The difference between these two uses of the definite description can also be illustrated by how one answers a question containing a definite description. In a question, when one uses a definite description referentially, one "may succeed in picking out a person or thing to ask a question about even though he or it does not really fit the description." ${ }^{45}$ On the other hand, when one uses a definite description in a question attributively, "if nothing fits the description, no straightforward answer to the question can be given." ${ }^{46}$ To illustrate, imagine that we are in a party and looking at a person that one is interested about. ${ }^{47}$ One then asks one's friend the question "Who

\footnotetext{
${ }^{44}$ Ibid., 285--286.

${ }^{45}$ Ibid., 287.

${ }^{46}$ Ibid.

${ }^{47}$ Ibid.
}

(c) 2018 Joseph Martin M. Jose and Napoleon M. Mabaquiao, Jr. https://www.kritike.org/journal/issue 23/jose\&mabaquiao december2018.pdf ISSN 1908-7330

(c) BY-NC-ND 
is the person drinking martini?" If the definite description "the person drinking martini" is used referentially, and one succeeds in leading one's hearer to pick out the individual one is talking about in the question, the question can still be answered if it happens that the individual is not really drinking martini but water. But, if the definite description is used attributively, and the individual one is talking about is not drinking martini, then the question cannot be answered for the individual does not fit the attribute specified in the definite description. In this case, the attribute is what is important and not the person. The attribute must be satisfied in order for the question to have a straightforward answer.

In commands or orders, "when a definite description is used attributively....and nothing fits the description, the command cannot be obeyed...."48 On the other hand, when a definite description is used referentially, whether or not the person or thing fits the description, the command or order can still be obeyed. For example, Donnellan asks us to imagine that someone is ordered, "bring me the book on the table." If the command is used referentially but the book happens not to be on the table but beside or under it, this command can still be obeyed and one may return to the person issuing such command with the right book at hand. ${ }^{49}$ It is because the attribute of being on the top of the table is not important since both of them knew in their minds what book they are talking about. On the other hand, if such a definite description was used attributively, then the command cannot be obeyed at all if there is no book on the table or if the book is beside or under such table. It is because what is important is the book fitting the description that it is on top of the table.

Let us now look into how the difference of the two uses of definite descriptions will show that that there is a confusion between Gettier's understanding of Smith's epistemic situation and Smith's understanding of his own situation. By epistemic situation we simply mean a circumstance wherein knowledge is at play or is at stake. As we have earlier noted, the definite description that is in question in the first original case, the Smith case, is "the man who will get the job." Now one may ask in what way is such definite description used in the case of Smith when he uttered the proposition "The man who will get the job has ten coins in his pocket?" To begin with, there are two perspectives that have to be considered here. One is the perspective of Smith (which is Smith's experience of his own epistemic situation), and second is the perspective of Gettier (which is his analysis/understanding of the epistemic situation of Smith). From the perspective of Smith, he uttered such a proposition after having been justified

48 Ibid., 288.

${ }^{49}$ Ibid., 287-288.

(c) 2018 Joseph Martin M. Jose and Napoleon M. Mabaquiao, Jr. https://www.kritike.org/journal/issue 23/jose\&mabaquiao december2018.pdf ISSN 1908-7330 


\section{RESOLVING THE GETTIER PROBLEM}

with the evidences (a) that the president of the company told him that Jones would surely be the one who would get the job, and (b) that he knew that Jones had ten coins in his pocket (upon earlier counting them). This only means that the person that Smith has in mind in uttering such definite description and supported by the evidences the he has is Jones. It is Jones and only Jones that Smith has in mind in using the definite description "the man who will get the job." In fact, Smith could have used other definite descriptions to pick out Jones such as "The man whom the president has chosen" or "The man who was with me in the waiting room." Whichever of these that Smith might have used, it will not change the person that he has in mind, which is Jones.

We can thus say that Smith uses the definite description in the referential sense. If we situate such definite description in the JTB, indeed in his belief that "The man who will get the job has ten coins in his pocket," he is referring to Jones and Jones alone. Furthermore, the truth of his proposition, in which the definite description appears, should be determined only in the context of the referential use of the definite description; that is, if it is indeed Jones who will get the job and that he has ten coins in his pocket. If it is not Jones who will get the job, regardless of whether Jones has ten coins in his pocket, the proposition is false. ${ }^{50}$

What is crucial here, however, is when we take into consideration the perspective of Gettier. As we have seen in the original Gettier case, there was something strange that occurred. It was Smith who got the job and that Smith himself has ten coins in his pocket. From such occurrence, Gettier then says that the proposition (e) "The man who will get the job has ten coins in his pocket" is true by virtue of Smith (1) having gotten the job and (2) having also ten coins in his pocket. Smith's belief that proposition (e), according to Gettier, is still true even though what Smith has in mind is Jones. Further, Smith is still justified in believing proposition (e) since his belief is based on evidences and grounds by which he is really justified in having. As we can see, the analysis clearly shows that Gettier is using the definite description, or understands Smith's use of the definite description, in the attributive way because he does not really care about the fact that what Smith has in mind is Jones. What he cares about is to state that whoever will fit the description "the man who will get the job" has ten coins in his pocket.

Smith and Gettier differ as to how they understand the use of the definite description in Smith's proposition. But whose use is the right one?

${ }^{50}$ The proposition "The person who will get the job has ten coins in this pocket," is actually a conjunction of two propositional functions; namely: " $X$ will get the job" and " $X$ has ten coins in his pocket." So, if one of these functions will yield a false proposition, the original function is automatically false, regardless of whether the other propositional function will yield a true proposition.

(c) 2018 Joseph Martin M. Jose and Napoleon M. Mabaquiao, Jr. https://www.kritike.org/journal/issue 23/jose\&mabaquiao december2018.pdf ISSN 1908-7330

$(\mathrm{Cc}) \overline{\mathrm{BY}-\mathrm{NC}-\mathrm{ND}}$ 
Definitely the person uttering the proposition, which is Smith, for it is Smith who is making a knowledge claim with regard to the proposition "The man who will get the job has ten coins in his pocket." The question is whether Smith really knows $\mathrm{p}$ when he utters $\mathrm{p}$; and not whether Gettier knows $\mathrm{p}$ when Smith utters p. It is Smith who has the belief in question and the justification in question for the truth of this belief. What we are considering is the epistemic situation of Smith, whether it is an instance of JTB; and not the epistemic situation of Gettier.

Now given that Smith uses the definite description "the man who will get the job" in his proposition "The man who will get the job has ten coins in his pocket" in the referential sense, this proposition of his is not true but false given that it is Smith, and not Jones, who will get the job. If this proposition is false, then Smith's proposition is not a case of JTB at all. For though the conditions of belief and justification are satisfied, the condition of truth is not. What in fact happened is that Gettier imposed his attributive understanding of the definite description onto Smith's own mind or epistemic situation.

This confusion can also be seen in the other versions of the Gettier cases. Although, there is no explicit definite description that can be extracted from such versions, the dynamics of the uses of definite descriptions can still be applied. For instance, in the case of the sheep in the field, the proposition "There is a sheep in the field" can have an attributive and referential uses. The man looking at a particular sheep in the field and then uttering the proposition "There is a sheep in the field" is operating in the referential use since he has that particular animal in mind. He is using such proposition for us, his audience, to pick out that animal he is referring to. On the other hand, the "Gettier" in this case used it attributively, in a sense that the truth of the proposition was not dependent on whether or not that sheep in front of him was indeed a sheep. The proposition being luckily true was based on a sheep that was behind the hill. Hence, what is important was there is a sheep that satisfies the definite description in the proposition. The "Gettier" does not care about the animal in front of the person.

If we now go back to the argument of Gettier, P2 states that "there are instances where JTB obtains, but knowledge does not obtain;" hence, leading him to conclude that JTB is not sufficient for knowledge. Gettier instantiated P2 via his two cases. Therefore, for Gettier, his two cases are cases of JTB. But our analysis shows the contrary. The case of Smith is in fact not a case of JTB. Having shown earlier that the truth condition does not hold makes Gettier's case problematic. It is because it fails to be a case of JTB, and if it fails to be one, then Gettier would not be able to push further his P2 since he has to make sure that the cases that will instantiate P2 are really cases of

(c) 2018 Joseph Martin M. Jose and Napoleon M. Mabaquiao, Jr. https://www.kritike.org/journal/issue 23/jose\&mabaquiao december2018.pdf ISSN 1908-7330 


\section{RESOLVING THE GETTIER PROBLEM}

JTB, but as we have shown, one of them is not. This then will put the whole argument of Gettier in question.

\section{Conclusion}

In this paper, we have attempted to respond to the Gettier problem by engaging in the so-called "linguistic turn" in the approaches to the Gettier problem. Specifically, we engaged Donnellan's distinction of the attributive and referential uses of definite descriptions to analyze the first Gettier case and a version of such case. In that analysis, we have shown that the definite description "the man who will get the job" in the proposition "The man who will get the job has ten coins in his pocket" is a definite description that can have an attributive and a referential function. Smith, within his own epistemic situation, makes use of such definite description referentially; on the other hand, Gettier, in his analysis of the epistemic situation of Smith, makes use of such definite description attributively. From such difference in uses, we have shown that there is an equivocation at play in the Gettier case. But since it is the epistemic situation of Smith that is in question, it is thus Smith's use of the definite description that should be considered. And in this regard, Smith's proposition is false, thereby disqualifying Smith's proposition as a case of JTB. Consequently, the Smith case fails to serve as a counterexample to the JTB account of knowledge.

Philosophy Department, De La Salle University, Manila, Philippines

\section{References}

Atkins, Philip, “Are Gettier Cases Misleading?" Logos \& Episteme, 7:3 (2016). Austin, J. L. How to do Things with Words (Oxford: Oxford University Press, 1962).

"Performative-Constative," in The Philosophy of Language, ed. by John Searle (Oxford: Oxford University Press, 1971).

Chisholm, Roderick, (Theory of Knowledge. New Jersey: Prentice Hall, 1966).

Christoph Schmidt-Petri, Konstanz, "Is Gettier's First Example Flawed?" in Knowledge and Belief, ed. by Winfried Loffler and Paul Weingartner (Austrian Ludwig Wittgenstein Society, 2003).

Dancy, Jonathan, An Introduction to Contemporary Epistemology (Oxford: Blackwell Publishing, 1985).

Donnellan, Keith, "Reference and Definite Descriptions," The Philosophical Review, 75:3 (1966).

Feldman, Richard, "An Alleged Defect in Gettier Counterexamples," Australasian Journal of Philosophy, 52 (1974).

(c) 2018 Joseph Martin M. Jose and Napoleon M. Mabaquiao, Jr. https://www.kritike.org/journal/issue 23/jose\&mabaquiao december2018.pdf ISSN 1908-7330

(c) $)$ BY-NC-ND 
Gettier, Edmund, “Is Justified True Belief Knowledge?" Analysis. 23:6 (1963). Goldman, Alvin, "A Causal Theory of Knowing," Journal of Philosophy, 64:12 (1967).

"Discrimination and Perceptual Knowledge," Journal of Philosophy, 73 (1976).

Hazlett, Allan, "The Maturation of the Gettier Problem," Philosophical Studies, 172:1 (2015).

Hetherington, Stephen, Good Knowledge, Bad Knowledge: On Two Dogmas of Epistemology (Oxford: Oxford University Press, 2000).

Lehrer, Keith, "Why Not Skepticism?" The Philosophical Forum, 2 (1971).

Lehrer, Keith and Thomas Paxson, Jr., "Knowledge: Undefeated Justified True Belief." Journal of Philosophy, 66:8 (1969).

Lemos, Noah, An Introduction to the Theory of Knowledge (Cambridge: Cambridge University Press, 2007).

Mabaquiao, Napoleon, Jr., Mind, Science and Computation (Quezon City: Vibal Publishing Inc. and De La Salle University, 2012).

Mizhari, Moti, “Why Gettier Cases are Misleading," Logos \& Episteme, 7:1 (2016).

Knobe, Joshua, and Shaun Nichols, Experimental Philosophy (Oxford: Oxford University Press, 2008).

Searle, John, Mind, Language and Society: Doing Philosophy in the Real World (London: Weidenfeld and Nicolson, 1999).

Skyrms, Brian, "The Explication of 'X knows that $\mathrm{p}^{\prime}$," Journal of Philosophy, 64:12.

Sosa, Ernest, "Can there be a Discipline of Philosophy? And can it be Founded on Intuitions?" Mind and Language, 26:4 (2011).

Tomassi, Paul, Logic (London: Routledge, 1999).

Unger, Peter, “A Defense of Skepticism." The Philosophical Review, 80:2 (1971): 198-219.

"An Analysis of Factual Knowledge" Journal of Philosophy, 65:6 (1968).

Weinberg, Jonathan, Shaun Nichols, and Stephen Stich, "Normativity and Epistemic Intuitions," in Philosophical Topics, 29:1/2 (2001).

Yakubu, Yussif, "Truth Analysis of the Gettier Argument," Metaphilosophy, 47:3 (2016).

Zagzebski, Linda, "The Inescapability of Gettier Problems," Philosophical Quarterly, 44:174 (1994).

(c) 2018 Joseph Martin M. Jose and Napoleon M. Mabaquiao, Jr. https://www.kritike.org/journal/issue 23/jose\&mabaquiao december2018.pdf ISSN 1908-7330 
Article

\title{
The Reinterpretation of Tetsurô Watsuji's Communitarian Thought
}

\section{Donghyun Kim}

\begin{abstract}
This paper reconsiders Tetsurô Watsuji's ethics as communitarian thought and the ontological-existential idea by observing his philosophical arguments. Watsuji uses a historicohermeneutical research scheme in considering ethics as a reflection of the place where human beings live. He comprehends the quintessence of human existence as the dual mode of individual and society in terms of it being largely based on the "betweenness" of dialectical movement between the individual and society. Hence, Watsuji's ethics can be postulated as East Asian communitarianism that stipulates the duties and attitudes of people living in East Asian societies. In addition, Watsuji seeks the genuine meaning of ethics by illuminating two concepts: fudo (climate) and ningen (human being). In so doing, he underscores the existential aspect of human existence, highlighting the social and cultural environment. Watsuji points out that Heidegger has not fully reflected on the mode of human existence with the sole concept of time; rather, unlike Heidegger, Watsuji puts forth an argument that the human existence is fundamentally influenced by a particular space and climate. Watsuji ultimately articulates that human beings can become existential subjectivity through the process of the voluntary double negation of human beings that is basically embedded in the communitarian thought. Therefore, Watsuji's philosophical thought connotes the notions of communitarianism and ontological existentialism.
\end{abstract}

Keywords: communitarianism, ontological existentialism, space double negation

(c) 2018 Donghyun Kim

https://www.kritike.org/journal/issue 23/kim december2018.pdf

ISSN 1908-7330 


\section{Introduction}

$\mathrm{L}$

afleur contends that Tetsurô Watsuji's philosophical arguments cover the difference of cultural diversity between the East and the West. ${ }^{1}$ Watsuji's philosophy is, on one hand, deeply rooted in the extensively ancient Japanese culture, primitive Buddhism, and primitive Confucianism ${ }^{2}$ while, on the other hand, influenced by Heidegger's phenomenological existentialism. ${ }^{3}$ To be sure, Watsuji's thought has dealt with the comparative analysis of Eastern and Western philosophical tradition. With his elaboration of the cross-cultural traditions of the East and West, the fundamental essence of his philosophical arguments lies in ethics based primarily on the intense reflection of human being and human existence.

Researchers' previous studies regarding Watsuji's thought vary. Some researchers argue that his idea emphasizes the Japanese emperor system. ${ }^{4}$ According to Piovesana's analysis, Watsuji's philosophical idea on ethics is absolutely socio-communitarian in nature. ${ }^{5}$ Dorsey, on the other hand, claims that Watsuji's thought is neither communitarian nor liberal, ${ }^{6}$ while Sevilla considers Watsuji as a thinker who has both liberal and communitarian thought. ${ }^{7}$ In short, Watsuji's thoughts can be demarcated into

${ }^{1}$ William Lafleur, "Reasons for the Rubble: Watsuji Tetsurô's Position in Japan's Postwar Debate about Rationality," in Philosophy East and West, 5:1 (2001), 1-25.

2 Yukichi Fukuzawa, An Outline of a Theory of Civilization, trans. by Dilworth and Hurst (Tokyo: Sophia University Press, 1973), 226.

${ }^{3}$ David A. Dilworth, "Guiding Principles of Interpretation in Watsuji Tetsurō's History of Japanese Ethical Thought: With Particular Reference to the Tension between the Sonno and Bushido Traditions," in Neglected Themes and Hidden Variations ed. by Victor Sōgen Hori and Melissa Anne-Marie Curley (Nagoya, Japan: Nanzan Institute for Religion and Culture, 2008), 101-112; Kristyna Vojtǐsková, "The Crisis of Japanese Identity in the $21^{\text {st }}$ Century and Watsuji Tetsurô's Ethics," in Asian Studies, 3:1 (2015), 129-144.

${ }^{4}$ Robert Bellah, “Japan's Cultural Identity: Some Reflections on the Work of Watsuji Tetsuro," in The Journal of Asian Studies, 24:4 (1965), 573-594; C. L. Starling, "Asserting Selflessness: The Case of Watsuji Tetsurô," in Shoin Review, 42 (2001), 33-56.

${ }^{5}$ Gino K. Piovesana, Recent Japanese Philosophical Thought 1862-1996: A Survey (London: Routledge, 1996), 141.

${ }^{6}$ Luke Dorsey, “A Japanese Ethics of Double Negation: Watsuji Tetsurô's Contribution to the Liberal-Communitarian Debate," in Otherwise: An Online Journal of Philosophy (2007), 1-13.

7 Anton Luis Sevilla, "Watsuji's Balancing Act: Changes in His Understanding of Individuality and Totality from 1937 to 1949," in Journal of Japanese Philosophy, 2 (2014), 105-134.

(c) 2018 Donghyun Kim

https://www.kritike.org/journal/issue 23/kim december2018.pdf

ISSN 1908-7330

(cc) BY-NC-ND 


\section{TETSURÔ WATSUJI'S COMMUNITARIAN THOUGHT}

four respects: totalitarian, ${ }^{8}$ pseudo-liberalist, ${ }^{9}$ communitarian, ${ }^{10}$ and neither liberal nor communitarian. ${ }^{11}$

This paper will examine not only Watsuji's philosophical standpoint imbedded mainly in communitarian thought by examining his account of ethics, but also the understanding of human existence based predominantly on ontological existentialism. Thus, this paper attempts to demonstrate that Watsuji's philosophical idea mainly involves communitarian thoughts as well as a connotation of concomitantly ontological-existential ideas.

\section{Watsuji's Communitarian Idea grounded in Ontological Existentialism}

To establish his own philosophical outlook, Watsuji attempted to directly respond to Heidegger's book, Sein und Zeit (Being and Time). Watsuji's philosophical foundation reconsiders the ontological aspect of human existence. The basic idea of his ethics embedded in humanity can be understood as "betweenness" between individuals and society so that the human existence is constituted in the dialectical movement between the two. ${ }^{12}$ Watsuji's ethics is largely based on the concept of "betweenness" founded on the principle of "the fundamental law of human beings." 13 In this sense, Watsuji's primary interest at its core lies in ethics premised on the ontological-existential foundation of human existence.

In his book Rinrigaku, Watsuji challenges the Western idea of the relationship of the individual to society. He asserts that this relationship originally derives "from the standpoint of the dual structure-both individual and social - of human existence, [it] did not advance beyond an

\footnotetext{
8 Bellah, “Japan's Cultural Identity," 573-594; Starling, "Asserting Selflessness," 33-56.

${ }^{9}$ See Fukuzawa, An Outline of a Theory of Civilization; Nao Oyama, "Some Recent Trends in Japanese Values: Beyond the Individual-Collective Dimension," in International Sociology, 5 (1990), 445-459.

${ }^{10}$ Yōtarō Kobayashi, "Japan's Individualism in Globalization Trends," in Global Communications Platform: Japanese Institute of Global Communications (9 March 2007), http://glocom.org/opinions/essays/200012 kobayashi jp individ/index.html, 13 April 2017; Piovesana, Recent Japanese Philosophical Thought, 141; Starling, "Asserting Selflessness," 33-56; Jeffrey Wu, "The Philosophy of As-Is: The Ethics of Watsuji Tetsuro," in Stanford Journal of East Asian Affairs, 1 (2001), 96-102.

${ }^{11}$ Dorsey, “A Japanese Ethics of Double Negation," 1-13; Anton Luis Sevilla, “The Communality of Creativity and the Creativity of Community: A Comparison of the Ethics of Nikolai Berdyaev and Watsuji Tetsurô," in Kritika Kultura, 15 (2010), 226-253; Sevilla, "Watsuji's Balancing Act," 105-134; Vojtǐsková, "The Crisis of Japanese Identity," 129-144.

${ }^{12}$ Dorsey, "A Japanese Ethics of Double Negation," 1-13; James M. Shields, “The Art of Aidagara: Ethics, Aesthetics, and the Quest for an Ontology of Social Existence in Watsuji Tetsuro's Rinrigaku," in Asian Philosophy, 19:3 (2009), 265-283.

${ }^{13}$ Tetsurô Watsuji, Watsuji Tetsurô's Rinrigaku, trans. by Robert Carter (Albany: State University of New York Press, 1996), 119.

(c) 2018 Donghyun Kim

https://www.kritike.org/journal/issue 23/kim december2018.pdf

ISSN 1908-7330

(c) BY-NC-ND
} 
abstraction of a single aspect." 14 In contrast to Heidegger's understanding of human existence, Watsuji proclaims that the ethics of human beings should be understood as the dual mode of individual and social of human existence. Heidegger reflects the human existence that is mainly premised on the individual aspect of human beings. Heidegger argues that, "existentially, the constancy of the self means nothing other than anticipatory resoluteness. Its ontological structure reveals the existentiality of the selfhood of the self...the self that is revealed by the reticence of resolute existence [which] is the primordial phenomenal basis for the question of the being of the 'I.'" 15 In Being and Time, Heidegger claims an individualist account of the authentic self as a genuine feature of human beings that is largely a solitary self in explicating human existence. Moreover, Heidegger argues that the "authentic potentiality-of-being" of human existence is only revealed within the context of temporality. ${ }^{16}$ Due to the finitude of human existence associated with temporality, the individualistic aspect of human existence is inevitable in that Heidegger's understanding of human existence conjures up a "voluntaristicindividualistic interpretation of authenticity." 17 Likewise, O'Connell clarifies that the authentic human being (Dasein) as a mode of human existence plays out its own free choices that are completely distinct from social activity. ${ }^{18}$ Thus, although Heidegger to some extent elucidates the social aspect of human beings as being-in-the-world along with other individuals, he primarily maintains an individualistic account of authenticity, particularly when human beings are an inexorably individualistic self. In short, whereas Heidegger seeks to elaborate humans' feature of finite individual life in his philosophy, Watsuji sketches out the essential elements of how finite human existence should be explicated in association with the circumstantial situation (i.e., space).

Watsuji critiques Heidegger for having placed too much emphasis on time and the individual, thus lacking a reflection on the importance of space and the social feature of human beings. Unlike Heidegger, Watsuji argues that human existence should be treated as revealing the dual importance of time and space. ${ }^{19}$ At the same time, Watsuji claims that the social environment of family, community, and society that surrounds human beings is important

14 Tetsurô Watsuji, Watsuji Tetsurō zenshū, Vol. 10, (Kyoto, Japan: Iwanami Shoten, 1962), vi.

${ }^{15}$ Martin Heidegger, Being and Time, trans. by John Macquarrie and Edward Robinson (Cambridge: Blackwell Publishers, Ltd, 1962), 297.

${ }^{16}$ Ibid., 296.

17 Michael Zimmerman, Eclipse of the Self: The Development of Heidegger's Concept of Authenticity (Athens, Ohio: Ohio University Press, 1981), 199.

${ }^{18}$ Derek Robert O'Connell, "Heidegger's Authenticity" (Ph.D. Dissertation., University of Illinois at Urbana-Champaign, 2015), 15.

${ }^{19}$ Ibid., vi.

(c) 2018 Donghyun Kim

https://www.kritike.org/journal/issue 23/kim december2018.pdf

ISSN 1908-7330 


\section{TETSURÔ WATSUJI'S COMMUNITARIAN THOUGHT}

in determining one's understanding of human existence. According to Watsuji, the reality of human beings is closely related to, and influenced by, their geographical and social environments. In the following passage, manifested primarily in ontological existentialism, Watsuji insists on the link between the consciousness of the ego and the sociality of human beings:

What is required for us to search for the independent consciousness of the ' $\mathrm{I}$ ' is the positing of the standpoint of the ' $\mathrm{I}$ ' as existing alone, in which there is no one else with whom the ' $\mathrm{I}$ ' shares the same consciousness. This is the case when, while alone, I look at the wall in my study and think of [my-self] that is looking at it. However, in this case if I have become conscious of the wall as a wall, then social consciousness has already intervened. What is called a wall is that 'form' society imprints on clay or sand as a specific toll (that is, as part of a house). ${ }^{20}$

In this passage, Watsuji demonstrates a communitarian idea in association with the ontological-existential underpinning of human existence that is somewhat akin to Hegel who posits a political system that rests upon both the individual and the whole. Watsuji draws out Hegel's communitarian thought of "the unity of the self and the other," 21 which consists of the fundamental structure of social ethics of human community. In Hegel's account, the nature of humans' everyday life means human agents are individuals interacting in a society. ${ }^{22}$ The characteristic of ethical actions of individuals in society is not only derived from the harmonious collectivity of all members of a community, but also requires self-conscious individuals who have shared their understanding of truth and values and who belong to the specific community. In this sense, Hegel's insistence on the "perfect balance of individuality and identification with the social whole" entails the communitarian notion of human beings who are constantly interacting with other individuals in a particular community. ${ }^{23}$ Watsuji ascertains that, in "social ethics, I can be I only by virtue of its not being isolated and independent." 24

${ }^{20}$ Watsuji, Rinrigaku, 73.

${ }^{21}$ G. W. F. Hegel, Hegel's Philosophy of Right, trans. by T. M. Knox (New York:

Oxford University Press, 1952), § 158.

22 Ibid., § 192.

${ }^{23}$ Jon Stewart, The Unity of Hegel's "Phenomenology of Spirit": A Systematic Interpretation (Evanston: Northwestern University Press, 2011), 238.

${ }^{24}$ Watsuji, Rinrigaku, 83.

(c) 2018 Donghyun Kim

https://www.kritike.org/journal/issue 23/kim december2018.pdf

ISSN 1908-7330

(cc) BY-NC-ND 
In a similar vein, Taylor, who is a communitarian heir of Hegel's moral framework on human society, contends that one's identity is exclusively defined by a fellowship of community or society to which human beings belong:

To speak of orientation is to presuppose a spaceanalogue within which one finds one's way. To understand our predicament in terms of finding or losing orientation in moral space is to take the space which our framework seeks to define as ontologically basic. The issue is, through what framework-definitions can I find my bearings in it? In other words, we take as basic that the human agent exists in a space of questions. And these are the questions to which our framework definitions are answers, providing the horizon within which we know where we stand, and what meanings things have for us. ${ }^{25}$

Taylor maintains that the activities of human beings are fundamentally determined by the commitments and identifications of social role in the specific communal society which Watsuji elucidates as 'space.' Watsuji refers to space as the particular communal society that plays an important role in shaping the moral framework of human beings. Typically, the communitarian thought invokes and underscores the role of community or space based on geographical location. In this sense, Taylor espouses Watsuji's emphasis on space, which contrasts with Heidegger's acknowledgement of time in exploring the existential feature of human beings. Watsuji's idea of the moral framework of human beings is similar to Hegel at the outset and Taylor, who succeeds Hegel's communitarian thought by recognizing the individual identity that is not simply determined by one's own transcendental idea, but by the social environment of the community. Like the Hegelian synthetic analysis of the individual and the whole, which aims to ultimately achieve the absolute spirit of the world (Geist), Watsuji asserts that human existence is to be investigated in terms of both the individual and the society. Hegel refers to the absolute spirit of the world (Geist) as the state that is essential to human beings and exercises its power over individuals. As a result, Hegel recognizes that it is important for communities to maintain the relationships between individuals and the state. Thus, Watsuji seeks to focus on everyday life and politics in favor of individual authenticity, which is only

${ }^{25}$ Charles Taylor, Sources of the Self: The Making of the Modern Identity (Cambridge, M.A.: Harvard University Press, 1989), 29.

(c) 2018 Donghyun Kim https://www.kritike.org/journal/issue 23/kim december2018.pdf ISSN 1908-7330 


\section{TETSURÔ WATSUJI'S COMMUNITARIAN THOUGHT}

possible based on the collective authenticity of communities as Hegel conceives them. ${ }^{26}$ As Mulhall and Swift write, "the identity of human self is bound up with the self's sense of the significance and meaning of the objects and situations it encounters in [social] life." 27 Over the idea of an autonomous individual, Dorsey aptly describes the main feature of communitarianism as an individual who is bound up with social influence. ${ }^{28}$ Likewise, Watsuji seemingly asserts that the social influence toward human beings is largely shaped by space.

Through his communitarian idea, Watsuji claims that the identity of human beings is entirely derived from their social environment or community or space. In addition, Watsuji's essential understanding of the notion of human existence is deeply embedded in Heidegger's ontological existentialism, even though he tries to deviate from Heidegger's thought. ${ }^{29}$ However, unlike Heidegger's commitment to the idea of the finitude of human existence based on his ontological existentialism primarily emphasizing time and the individual, Watsuji calls attention to the space and the social dimensions of human beings. In short, Watsuji's philosophical thought denotes a combination of Hegelian communitarianism and Heideggerian ontological existentialism.

\section{Watsuji's Philosophical Understanding of Ethics and Human Existence}

Watsuji's philosophical interests mainly focus on two concepts related to each other: ethics, and human existence. Watsuji begins to examine the etymological meanings of the ningen (human being, 人間) and Rinringaku (ethics) in order to explore the idea of ethics. He attempts to seek out the true meaning of ethics by explaining two concepts: fudo (climate) and ningen (human being). For Watsuji, fudo refers to nature, meaning "wind and earth...[and] the natural environment of a given land," 30 while ningen means human being. Watsuji recognizes that ethics is the study of human beings and that the locus of ethics lies in the "in-betweenness" of human beings, that is,

\footnotetext{
${ }^{26}$ Michael Gillespie, "The Search for Immediacy and the Problem of Political Life in Existentialism and Phenomenology," in A Companion to Phenomenology and Existentialism, ed. by Hubert L. Dreyfus \& Mark A. Wrathall (Oxford: Wiley-Blackwell, 2009), 532.

27 Stephen Mulhall and Adam Swift, Liberals and Communitarians (Oxford: Blackwell Publishers Ltd, 1992). 13-15.

${ }^{28}$ Dorsey, "A Japanese Ethics of Double Negation," 4.

${ }^{29}$ Sumiko Eguchi, Being a Person: The Ethics of Watsuji Tetsurô and Immanuel Kant (M.A. Thesis, The Ohio State University, 2009), 2-3. Isamu Nagami, "The Ontological Foundation in Tetsuro Watsuji's Philosophy: Kū and Human Existence," in Philosophy East and West, 31:3 (1981), 282; Starling, "Asserting Selflessness," 45-48.

${ }^{30}$ Watsuji, Tetsurō zenshū, 1.

(c) 2018 Donghyun Kim

https://www.kritike.org/journal/issue 23/kim december2018.pdf

ISSN 1908-7330
}

(c) BY-NC-ND 
person to person. ${ }^{31}$ Ningen is composed of two characters: rin, meaning "person" or "human being," and gen, meaning "space" or "between." For Watsuji, a human being is not just an isolated individual, but is also a member of a social group or the group itself: "Rinri, that is, ethics, is the order or the pattern through which the communal existence human beings rendered possible. In other words, ethics consists of the laws of social existence." 32 Offering an etymological analysis, Watsuji explains that human beings certainly pursue "fellowships" because "rin means nakama, signifies a body or a system of relations, which a definite group of persons have respect to each other." 33 In short, Watsuji reasons that humans are social or political beings in that each member of a specific society seeks out a practical connection among human beings. In this context, it can be said that Watsuji shares Aristotle's idea that "human beings are by nature political animals" because individuals are socially immersed in a society from which they cannot escape. In other words, humans are social beings who are easily vulnerable to their environment.

Yet, to a certain extent, Watsuji is not simply a thinker who embraces full-fledged communitarian ideas with regard to his reflection on the essence of human beings and human existence. He also touches upon the importance of isolated individuals by signifying the meaning of the Japanese term nin because it also connotes "person" or "human being." In Watsuji's examination of the etymology of original Chinese characters, the word ningen means "an individual human being." Literally, it means 'between persons' by stating that "on the basis of the evolving meaning of [ningen]...is the public and, at the same time, the individual human beings within it." ${ }^{34}$ Moreover, Watsuji asserts that ethics is the study of human beings (ningen), and it is inevitably perceived as an intimate relationship between the individual and the society. Accordingly, ethics is to be envisaged as "a dual focus on both individuality of the person and the sociality of human relatedness [which is] manifested in the relationships a human being is situated in." 35 Sevilla clearly sheds light on Watsuji's understanding of human existence as follows:

human existence is characterized by a dual-structure (nijûkôzô): it possesses both individuality (kojinsei) and totality (zentaisei). To try to grasp human existence from merely one of these one of these facets (as in individualism and collectivism) is folly, and to be

\footnotetext{
${ }^{31}$ Watsuji, Rinrigaku, 10.

32 Ibid., 11.

${ }^{33}$ Ibid., 10.

${ }^{34}$ Ibid., 13, 15.

35 Sevilla, "The Communality of Creativity," 234.
} 


\section{TETSURÔ WATSUJI'S COMMUNITARIAN THOUGHT}

faithful to only one of these aspects at the exclusion of the other is to go against the fundamental principle of human existence. Various commentators expound on this dual structure in order to express Watsuji's core ethical insight. ${ }^{36}$

At this point, Watsuji has emphasized both the individual human being and the human being who has an ethos of fellowship or membership in society. Thus, Watsuji's preliminary philosophical foundation prescribes the balanced dual nature of human beings, which means human beings must be steadily understood as aspects of both the individual and the social. As Watsuji argues, "neither side alone can explain human existence. But both sides exist only in negating each other. Hence it can be described as a negative dual structure." ${ }^{37}$ To be sure, Watsuji asserts this dual structure of human existence because he sees human existence as that which comprises both individuality and totality.

\section{Watsuji's Emphasis on the Notion of Double Negation}

By emphasizing the dual structure of human existence, i.e., the individual and social, one could say that Watsuji is invoking an eclectic view of the human being understood as individual human beings and individuals who belong to the community in which they live. However, from his etymological analysis of the word ningen (humang being), Watsuji's view of human existence is primarily embedded in the communitarian implication. In this context, Watsuji seemingly adopts Hegel's concept of negation (Aufhebung) in that his approach on the concept of self is closely tied to Hegel's dialectical scheme of negation. Now we can see how Watsuji brings forth the continuous process of negation of individuality and totality in the following:

An individual becomes an individual by negating emptiness (i.e., authentic emptiness) as her own fundamental source. This is the self-negation of absolute negativity. In addition to that, an individual must be subordinate to society through emptying herself, regardless of how this emptying is performed. This means that emptiness is materialized in various associations to varying degrees. Therefore, an individual returns to 'emptiness' itself, through engaging in association of whatever sort. In our attempt to comprehend wholeness itself, its essential feature was also revealed to be emptiness. Absolute wholeness is absolute negativity. Seen in this light,

36 Sevilla, "Watsuji's Balancing Act," 107.

37 Watsuji, Rinrigaku, 101-118. 
human association, inclusive of coercion, is understood to be the movement of negation of negation in which absolute negativity returns to itself through its own self-negation. ${ }^{38}$

Although Watsuji places greater emphasis on the role of individuality that is indispensable to the community, ${ }^{39}$ he appears to privilege totality over individuality. In this sense, the absolute negation of human beings between the individuals and the society is in accordance with Hegel's concept of the dialectical relationship of the individual and the whole. At first glance, Watsuji's assertion of the importance of the individuals is also parallel with that of the society; however, he still emphasizes the role of society by demonstrating the concept of "double negation." In other words, Watsuji's rejection of the self through the double negation leads to the idea that human beings depend upon society for their survival. ${ }^{40}$ In a sense, the idea that individuals should relinquish their right in order to carry out their obligatory role as a part of the whole or a member of certain society could be regarded as a communitarian indication. Moreover, Watsuji's emphasis of the communitarian idea is akin to that of ultra-rationalism or totalitarian thought, according to which the individual must abandon one's free and autonomous self in order for a community to exist. ${ }^{41}$ the community by negating oneself, and submerging individuality in totality. ${ }^{42}$ Here, Watsuji's concept of double negation in accordance with the emphasis of the particular environment does nothing but ascertain the importance of particularistic culture of Japan. Thus, his moral framework is primarily embedded in the culturally relativistic point of view of Japan.

In addition, Watsuji discusses the role of the whole compared to the individual as especially important by providing the following example of a family: "If parents stop behaving as parents, children as children, wives as wives, and husbands as husbands, then the family will be dissolved." 43 Thus, the family can only exist through the members who constitute it. Watsuji concurs with Hegel's idea of the family as the basic unit of human existence. ${ }^{44}$ In other words, the structure of human existence is expressed as the organizations or membership of the community that essentially arises from family. Accordingly, it can be said that Watsuji's understanding of ethics depicts a communitarian idea parallel with Hegel's notion of ethical life (sittlichkeit). Hegel elucidates the ethical life as follows:

${ }^{38}$ Ibid., 116-117.

39 Sevilla, "Watsuji's Balancing Act," 111.

${ }^{40}$ Sevilla, "The Communality of Creativity," 245.

${ }^{41}$ Bellah, "Japan's Cultural Identity," 590-591; Starling, "Asserting Selflessness," 40-41.

42 Dorsey, "A Japanese Ethics of Double Negation," 12.

${ }^{43}$ Watsuji, Rinrigaku, 89.

${ }^{44}$ Hegel, Philosophy of Right, §§ 33, 159.

(c) 2018 Donghyun Kim https://www.kritike.org/journal/issue 23/kim december2018.pdf ISSN 1908-7330 


\title{
136 TETSURÔ WATSUJI'S COMMUNITARIAN THOUGHT
}

\begin{abstract}
Ethical life is the Idea of freedom in that on the one hand it is the good become alive - the good endowed in selfconsciousness with knowing and willing and actualized by self-conscious action - while on the other hand selfconsciousness has in the ethical realm its absolute foundation and the end which actuates its effort. Thus ethical life is the concept of freedom developed into the existing world and the nature of self-consciousness. ${ }^{45}$
\end{abstract}

In Hegel's account, individuals in a particular political community who are largely exposed to its customs and conventions entirely follow the specific ethical principle of this society. Human beings are predominantly embedded in the specific ethical value associated with the ethical life derived from a particular community or society. According to Thompson, Hegel maintains that the moral life of individuals is "completely bound up with their participation" in a particular community. ${ }^{46}$ The Hegelian notion of ethical life refers to the concrete ethical value of human beings who put into effect the commitment of membership in a particular community.

For Watsuji, everywhere, we are determined by collectives - from a small organization of people, such as friendship and family, to a large organization of individuals such as large corporations, nations, and even the global village. Hence, this kind of philosophical argument displays the moral framework of communitarianism derived from the society, not the individual. Watsuji asserts his eclectic view on human beings; he writes: "society must be a community that exists in accordance with and among its members. But it is not communal because of its being universal. Conversely, it is universal because of its being communal. The state of a group becomes a phenomenon common to individuals, because it coerces individuals as that which commands." 47 Moreover, in this context, it can be said that his philosophical stance is closely tied to the fundamental communitarian idea of each member of society belonging to a specific practical interconnection among human beings. Watsuji considers all human beings to be vulnerable to the geographical land, topography, and climate in which they live, so that the mode of human beings is inescapably affected by environment. Thus, Watsuji's moral philosophy culminates in a communitarian ethics of the Japanese family system.

45 Ibid., § 142.

${ }^{46}$ Janna Thompson, Justice and World Order: A Philosophical Inquiry (London: Routledge, 1992), 113.

${ }^{47}$ Ibid., 111-112.

(C) 2018 Donghyun Kim

https://www.kritike.org/journal/issue 23/kim december2018.pdf

ISSN 1908-7330

(c) ) BY-NC-ND 


\section{Conclusion}

Watsuji's ethics primarily originates from a traditional human relationship of obligations and attitudes in the communities of the East. His idea entails the communitarianism that stipulates the traditional human relationship of human beings living in the East Asian community. He considers ethics to be the activity of human beings that is primarily affected by fudo (climate) and space (i.e., its geographical location), so that every society produces its specific culture. In other words, Watsuji's moral framework pinpoints a communitarian idea, signifying that fudo (climate) and space are closely related to the social and cultural aspect of human beings. Watsuji also presupposes the ontological existentialism of Heidegger's commitment to idea of the finitude of human existence in emphasizing the notions of space and the social dimensions of human beings. At the center of Watsuji's philosophical interests lie two concepts related to each other: ethics and human existence. Watsuji examines the ningen (human being) and Rinringaku (ethics) so as to explore the true meaning of ethics. He recognizes ethics as the intense reflection of how human beings exist for survival. Watsuji also highlights the role of space in shaping the ontological existential aspect of human existence. For Watsuji, ethics is the study of human beings; it lies in the "in-betweenness" of human beings. ${ }^{4}$ Accordingly, Watsuji affirms that ethics as the study of human beings (ningen) is inexorably the interactional relationship between individual and the society. Watsuji has emphasized both the individual human being and the human being who has an ethos of fellowship or membership in society. Moreover, his preliminary philosophical foundation prescribes the dual nature of human beings: human beings must be steadily understood as aspects of both the individual and the social. It can be said that Watsuji understands ethics as demonstrating the communitarian idea that is parallel with Hegel's notion of ethical life (sittlichkeit). In this sense, Watsuji's moral philosophy finally ends with a communitarian ethics of the particular Japanese family system. Thus, his communitarian thought can also be equally considered as an ontological-existential ethics based exclusively on Japanese culture.

Institute of Public Policy \& Administration, Chung-Ang University, South Korea

${ }^{48}$ Ibid., 10.

(c) 2018 Donghyun Kim

https://www.kritike.org/journal/issue 23/kim december2018.pdf

ISSN 1908-7330

(cc) BY-NC-ND 


\section{TETSURÔ WATSUJI'S COMMUNITARIAN THOUGHT}

\section{References}

Bellah, Robert N., "Japan's Cultural Identity: Some Reflections on the Work of Watsuji Tetsuro," in The Journal of Asian Studies, 24:4 (1965).

Dilworth, David A., "Guiding Principles of Interpretation in Watsuji Tetsurō's History of Japanese Ethical Thought: With Particular Reference to the Tension between the Sonno and Bushido Traditions," in Neglected Themes and Hidden Variations, ed. by Victor Sōgen Hori and Melissa Anne-Marie Curley (Nagoya, Japan: Nanzan Institute for Religion and Culture, 2008).

Dorsey, Luke, “A Japanese Ethics of Double Negation: Watsuji Tetsurô's Contribution to the Liberal-Communitarian Debate," in Otherwise: An Online Journal of Philosophy, (2007).

Hegel, G. W. F., Hegel's Philosophy of Right, trans. by T. M. Knox (New York: Oxford University Press, 1952).

Heidegger, Martin, Being and Time, trans. by John Macquarrie and Edward Robinson (Cambridge: Blackwell Publishers, Ltd, 1962).

Eguchi, Sumiko, Being a Person: The Ethics of Watsuji Tetsurô and Immanuel Kant (M.A. Thesis, The Ohio State University, 2009).

Fukuzawa, Yukichi, An Outline of a Theory of Civilization, trans. by Dilworth and Hurst (Tokyo: Sophia University Press, 1973).

Gillespie, Michael, "The Search for Immediacy and the Problem of Political Life in Existentialism and Phenomenology," in A Companion to Phenomenology and Existentialism, ed. by Hubert L. Dreyfus \& Mark A. Wrathall (Oxford: Wiley-Blackwell, 2009).

Kobayashi, Yōtarō, "Japan's Individualism in Globalization Trends," in Global Communications Platform: Japan Institute of Global Communications (9 March 2007), http://glocom.org/opinions/essays/200012 kobayashi jp individ/in dex.html, 13 April 2017.

Lafleur, William, "Reasons for the Rubble: Watsuji Tetsurô's Position in Japan's Postwar Debate about Rationality," in Philosophy East and West, 5:1 (2001).

Mulhall, Stephen and Adam Swift, Liberals and Communitarians (Oxford: Blackwell Publishers Ltd, 1992).

Nagami, Isamu, "The Ontological Foundation in Tetsuro Watsuji's Philosophy: Kū and Human Existence," in Philosophy East and West, 31:3 (1981).

O'Connell, Derek Robert, "Heidegger's Authenticity," (Ph.D. Dissertation, University of Illinois at Urbana-Champaign, 2015).

Oyama, Nao, "Some Recent Trends in Japanese Values: Beyond the Individual-Collective Dimension," in International Sociology 5 (1990).

(c) 2018 Donghyun Kim

https://www.kritike.org/journal/issue 23/kim december2018.pdf

ISSN 1908-7330

(cc) BY-NC-ND 
Piovesana, Gino K., Recent Japanese Philosophical Thought 1862-1996: A Survey (London: Routledge, 1996).

Sevilla, Anton Luis, "The Communality of Creativity and the Creativity of Community: A Comparison of the Ethics of Nikolai Berdyaev and Watsuji Tetsurô," in Kritika Kultura, 15 (2010).

"Watsuji's Balancing Act: Changes in His Understanding of Individuality and Totality from 1937 to 1949," in Journal of Japanese Philosophy, 2 (2014).

Shields, James M., "The Art of Aidagara: Ethics, Aesthetics, and the Quest for an Ontology of Social Existence in Watsuji Tetsuro's Rinrigaku," in Asian Philosophy, 19:3 (2009).

Starling, C. L., "Asserting Selflessness: The Case of Watsuji Tetsurô," in Shoin Review, 42 (2001).

Stewart, Jon, The Unity of Hegel's "Phenomenology of Spirit": A Systematic Interpretation (Evanston: Northwestern University Press, 2011).

Taylor, Charles, Sources of the Self: The Making of the Modern Identity, (Cambridge, M.A.: Harvard University Press, 1989).

Thompson, Janna, Justice and World Order: A Philosophical Inquiry (London: Routledge, 1992).

Vojtřsková, Kristyna, "The Crisis of Japanese Identity in the 21 ${ }^{\text {st }}$ Century and Watsuji Tetsurô's Ethics," in Asian Studies, 3:1 (2015).

Watsuji, Tetsurô, Watsuji Tetsurō zensh̄̄ 『和辻哲郎全集』Vol. 10，(Kyoto, Japan: Iwanami Shoten, 1962). Watsuji Tetsurô's Rinrigaku, trans. by Robert Carter (Albany: State University of New York Press, 1996).

Wu, Jeffrey, "The Philosophy of As-Is: The Ethics of Watsuji Tetsuro," in Stanford Journal of East Asian Affairs, 1 (2001).

Zimmerman, Michael, Eclipse of the Self: The Development of Heidegger's Concept of Authenticity (Athens, Ohio: Ohio University Press, 1981).

(C) 2018 Donghyun Kim

https://www.kritike.org/journal/issue 23/kim december2018.pdf

ISSN 1908-7330 
Article

\title{
Narrowing the Gap between Theory and Practice: Community of Inquiry and Its State in the Philippines
}

\section{Marella Ada V. Mancenido-Bolaños}

\begin{abstract}
This paper presents Matthew Lipman's critique of traditional pedagogy as seen in his work Thinking in Education (2003). Lipman points out that traditional pedagogy does not foster reflective thinking. This paper also discusses the historical development of the practice of community of inquiry in the Philippines from the time it was introduced by Zosimo Lee in 1996 to Manila Public Schools, and in 2012 to the teachers of Ayala Foundation, Inc. Teacher Training Institute. This article claims that Lipman's critique of traditional pedagogy mirrors the situation of Philippine classrooms. The author further argues that it is for this reason that the practice of community of inquiry still cannot be fully implemented in the country.
\end{abstract}

Keywords: Traditional pedagogy, Philosophy for Children, community of inquiry, reflective thinking

\section{Matthew Lipman's Critique of Traditional Pedagogy}

ccording to Matthew Lipman, the school is a battleground where the
future of the society is being fought. ${ }^{1}$ He adds that whereas schools
must be initiators of change, most of them remain conservative, as can be seen in the way teachers are trained in their craft. In most cases, teachers are taught to teach using manuals and textbooks. In this kind of training, their teaching ability is measured simply by their capacity to learn and memorize the manuals. Consequently, the change needed in the teaching profession cannot be initiated in the school system because of this practice.

In a democratic society, reasonableness must be inculcated in its citizens through the school system. According to Lipman, "reasonableness is

\footnotetext{
2003), 9.

(C) 2018 Marella Ada V. Mancenido-Bolaños

https://www.kritike.org/journal/issue 23/mancenido-bolanos december2018.pdf

ISSN 1908-7330
}

${ }^{1}$ Matthew Lipman, Thinking in Education (New York, NY: Cambridge University Press, 
not pure rationality; it is rationality tempered by judgment." 2 This implies that schools must exert a conscious effort to treat their students reasonably. Lipman aptly says that "children educated reasonably will then translate to reasonable citizens in the future." 3

With the focus of the curriculum shifting to making students master skills useful for future employability, where do we situate reasonableness in education? Just like their teachers whose ability to teach is measured by their ability to follow the manuals, the students' capacity to think becomes equated with how much of the lessons they have memorized. Likewise, their success is then measured by the scores they get in their exams and their performance tasks. Obviously, educators must start to realize that exam and performance task scores do not necessarily equate with the students' ability to think; rather, they measure the students' ability to copy.

Lipman notes that the "pedagogical problem is, at least in its first stage, to transform the child who is already a thinking child into a child who thinks well." 4 To address this problem, there must be a program that would enable children to address such cognitive tasks and making decisions for themselves. Educational systems, which aim at teaching thinking skills to students, must consider the idea of transforming children into philosophers or decision-makers. In other words, the system must teach children to become more thoughtful, more considerate, and more reasonable individuals. ${ }^{5}$

With these, we realize that there is a need for the development of critical practice as a methodical activity in education. But in order to develop such practice, it must be distinguished from what may be referred to as the "normal practice." A normal practice can be characterized as customary, habitual, traditional, or unreflective, while a critical practice is the opposite. What is normal can be turned into a critical practice through the following: 1) criticism of the practice of one's colleagues, 2) self-criticism, 3) correction of others, and 4) self-correction. Reflection upon a practice includes inquiry into it, while an effective inquiry includes appropriate intervention. ${ }^{6}$ Indeed, a reflective paradigm assumes education to be an inquiry.

Education is an inquiry. Teachers must be able to present a problem to the students rather than immediately offer them solutions they do not understand. The reason why students are not motivated enough is because they do not experience the process of discovering the solution. Therefore, the whole process becomes less fulfilling for them.

\footnotetext{
2 Ibid., 11 .

${ }^{3}$ Ibid.

${ }^{4}$ Matthew Lipman, Fredrick Oscanyan, and Ann Margaret Sharp, Philosophy in the Classroom (Philadelphia, PA: Temple University Press, 1980), 15.

${ }^{5}$ Ibid.

${ }^{6}$ Lipman, Thinking in Education, 16-17.
}

(c) 2018 Marella Ada V. Mancenido-Bolaños https://www.kritike.org/journal/issue 23/mancenido-bolanos december2018.pdf ISSN 1908-7330 


\section{COMMUNITY OF INQUIRY IN THE PHILIPPINES}

In the second chapter of Thinking in Education, Lipman strengthens his criticism of traditional pedagogical practices. He goes on discussing how teachers resist change and how schools, in turn, refuse to take responsibility for the future of the educational system. The teachers' education program cannot just be redesigned unless they have identified clearly the aims of education. ${ }^{7}$ Lipman notes that in this case "knowledge becomes disposable," 8 so that there is no retention of knowledge, what they have learned gets easily forgotten once examinations are over. Teachers of the traditional pedagogy know that the purpose of education is to instill knowledge, and yet even this very goal is not completely achieved because of the failure of the system to create an impact on the minds of the students. There are suggestions for critical thinking; the problem, however, is that teachers insist that they have been teaching for thinking and that nothing new needs to be done. ${ }^{9}$

As discussed earlier, Lipman has made significant criticisms against the standard teaching practices of educators, specifically how they tend to resist change in the system. Teachers are not prepared to teach critical thinking and there are no efforts to engage students to think imaginatively. He stresses that "there was very little teaching for judgment"10 basically because educators do not recognize the importance of teaching it. Teachers are also not able to create a connection between critical, creative, and caring thinking. ${ }^{11}$

From these criticisms, we can glean how future teachers must be taught. Truly, educational institutions must realize the necessity of reevaluating the teacher education program as this will benefit not only future teachers but also the future of the students. Also, learning institutions must realize that it is not enough to just pass on knowledge to students; but rather, the knowledge taught to students must now enable them to critically think for themselves in the future.

With these criticisms, Lipman, together with Ann Margaret Sharp, introduced the community of inquiry as an approach to teach children critical thinking. Lipman's founding of Philosophy for Children started when he realized in the 1970s that his children's school did not give them instruction in reasoning. The problem raised by Lipman is that schools fail to teach children how to think. Thus, he introduced the idea of making children be familiar with philosophy. He noted that when philosophy is properly taught,

\footnotetext{
${ }^{7}$ Lipman, Oscanyan, and Sharp, Philosophy in the Classroom, 207.

${ }^{8}$ Lipman, Thinking in Education, 29.

${ }^{9}$ Ibid., 31.

${ }^{10}$ Ibid., 5 .

11 Ibid.
}

(C) 2018 Marella Ada V. Mancenido-Bolaños

https://www.kritike.org/journal/issue 23/mancenido-bolanos december2018.pdf ISSN 1908-7330

(c) BY-NC-ND 
it could bring a significant improvement in students' thinking. This can be done by using the community of inquiry as a pedagogy. ${ }^{12}$

Lipman's community of inquiry is rooted in Charles Sanders Peirce's scientific inquiry. The term was "broadened to include any kind of inquiry whether scientific or non-scientific." 13 It aims to convert the classroom into a community of inquiry where students listen to one another with a certain level of respect toward one another's ideas. Lipman wants to transform education into a laboratory for rationality where students learn to be reasonable so that they can grow up to be reasonable citizens, reasonable companions, reasonable parents. ${ }^{14}$ Following Hirst, he notes that all scientific knowledge is contingent and must be justified by means of evidence and reasons. ${ }^{15}$ Lipman argues that knowledge should be a finished product of the inquiry process, it is logically organized in such a way that facts supported with evidence, and opinions are accompanied by reason and judgments are made with relevant criteria. He also uses Hirst's theory of thinking in the discipline where when a student is taught history, he must be able to think historically. ${ }^{16}$ Moreover, community of inquiry is also a process which has a sense of direction, that is, it moves where the argument takes it; it is dialogical. ${ }^{17}$ In such situations, we must see the teacher as the one who mediates and not the one who dominates the discussions. ${ }^{18}$ In this approach, we do not run the risk of indoctrinating students because the students are the ones who deliver the discussions based on their experiences and perspectives.

It is important to note that Lipman is aware of the present dilemma of educators. He knows that teachers are not given the free hand on how and what to teach their students because these are matters which are already decided on by school districts. On the other hand, he observes that children in kindergarten are curious, lively, imaginative, and inquisitive. These qualities dwindle as they age especially when these philosopher-like qualities are not nurtured. As a consequence, children eventually perceive only the social aspect of the school and forget about the educational aspect. ${ }^{19}$ Their enthusiasm for learning is not sustained because of the rigidity of the structured learning process. In the current system, we see how classroom discussions are focused on factual details. Students are being numerically graded through their scores in the examination which does not actually speak of how much they have learned but of how much they remember. On this

\footnotetext{
12 Ibid., 3-4.

${ }^{13} \mathrm{Ibid}, 20$.

${ }^{14}$ Ibid., 22.

${ }^{15}$ Ibid.

${ }^{16}$ Ibid., 24.

${ }^{17}$ Ibid., 83.

${ }^{18}$ Ibid., 84.

${ }^{19}$ Ibid., 12.
}

(c) 2018 Marella Ada V. Mancenido-Bolaños https://www.kritike.org/journal/issue 23/mancenido-bolanos december2018.pdf ISSN 1908-7330 


\section{COMMUNITY OF INQUIRY IN THE PHILIPPINES}

note, Van der Leeuw suggests, as quoted by Vansieleghem and Kennedy, that "reflection and reasoning cannot be realized when we only reserve separate hours a week for collective exploration of philosophical questions." 20

One might ask: If traditional schools are not open to the idea of transforming itself into becoming a more reflective and inquiry-based education system, is it possible to form communities of inquiry without transforming the whole education system?

David Kennedy suggests that this could or could not work, considering that there might be inconsistencies between what is being taught in the classroom of a community of inquiry and the traditional classroom setting which could confuse students. Yet, it could work because "wherever the community of inquiry actually forms, it will through its very operation work to transform its setting from transmission to dialogical." ${ }^{21}$ However, Kennedy recognizes that this is a weak proposition because if teachers cannot show how it relates to other aspects of school work, either the classroom will reject it or the scheme will simply not work. ${ }^{22}$ With this, we realize that there is really a need to transform the entire system into a community of inquiry, otherwise participants will not see its relevance and the system will not be able to instigate the change it wants.

While it is essential to learn the theories behind the facilitation of the community of inquiry, it is equally important to learn how to put it into practice. Transforming the system may be a necessity, but this transformation must begin with the teachers who are willing to take on the challenge. The next part of this paper will show how theory can be set into practice.

\section{Narrowing the Gap between Theory and Practice}

The new curriculum for preservice teacher education encourages deep and complex knowledge which emphasizes, according to Bernardo, the "acquisition and cognitive processing of more conceptual, theoretical, and abstract forms of knowledge ..., [stressing] the importance of understanding how knowledge and skills are contextualized or are meaningful in specific problem situations or context of inquiry." ${ }^{23}$ Bernardo suggests that teachers

\footnotetext{
${ }^{20}$ Nancy Vansieleghem and David Kennedy, "What is Philosophy for Children, What is Philosophy with Children-After Matthew Lipman?" Journal of Philosophy of Education, 45:2 (2011), 178

${ }^{21}$ David Kennedy, "The Community of Inquiry and Educational Structure," in Thinking Children and Education, ed. by Matthew Lipman (Dubuque, IA: Kendall/ Hunt Publishing Company, 1993), 356.

22 Ibid.

${ }^{23}$ Allan B.I. Bernardo, "Learning about Learning: Cognitive Processing Constraints in Teacher Educators Developing New Understanding about Learning and Pedagogy and How to
} 
must have an appreciation for the theories of knowledge and the technical strategies to be used in addressing specific aspects of learning.

Cognitive and metacognitive factors in learning are also included in the new curriculum. This dimension of learning is focused on the role of metacognitive process or, in other words, reflecting about thinking, in education. It is also concerned with eliciting the students' prior knowledge to enable the teacher to bridge the gap between what the students already know and what is yet to be learned.

It is noticeable that these new courses in the preservice teacher's curriculum are highly philosophical in nature. We read terms such as cognition, reflection, critical thinking, and nature of knowledge. Yet, when we review the actual curriculum of preservice teachers in the country, courses, such as Philosophy of Education or Epistemology, are absent. This is true even in the top-ranking colleges of education.

Instead of Philosophy of Education and Epistemology, the College of Education of the University of Santo Tomas offers History and Philosophy of Science to science majors and Philosophical and Ethical Foundations of Values Education to religious education majors. It is interesting to note that these two courses are not assigned to the Department of Philosophy. They have courses which are supposed to be philosophical in nature, such as Principles of Teaching I and II, which include the foundations of the discipline, as well as Facilitating Learning, which teaches contemporary theories and researches on the "cognitive, metacognitive, motivational, sociocultural, and individual difference factors in the acquisition of learning." 24 Both of these courses have a common prerequisite: Psychology 1.25

In addition, they offer Scientific Reasoning and Critical Thinking, which is "a study of the methodological components of the social sciences as tools to explain certain phenomena in the understanding of logical reasoning and critical thinking." 26 Finally, there is a Seminar in Education, which discusses the historical, legal, and philosophical foundations of education.

Unfortunately, the only subjects assigned to the Department of Philosophy are Logic and Professional Deontology. This seems anomalous if we consider assigning subjects to those who are equipped to teach courses according to their academic preparation and research. The presence of the term "thinking" in a course title does not immediately warrant that it belongs to psychology. Nor is the term social science exclusive to sociological theory.

Overcome Them," in Ripples of Change: A Journey of Teacher Education Reform in the Philippines (Quezon City: Commission of Higher Education, 2007), 60.

${ }^{24}$ University of Santo Tomas College of Education Course Prospectus (Manila, 2005), $72-94$.

${ }^{25}$ Ibid., 60-61.

${ }^{26}$ Ibid., 101.

(c) 2018 Marella Ada V. Mancenido-Bolaños https://www.kritike.org/journal/issue 23/mancenido-bolanos december2018.pdf ISSN 1908-7330 


\section{COMMUNITY OF INQUIRY IN THE PHILIPPINES}

The foundations or underlying theories of different fields and concepts are philosophical and could be appropriately handled only by the teachers who have the specific preparation for them.

The University of the Philippines does not offer the course Philosophy of Education in the undergraduate program; instead, they have Educational Thought and Practice. In the graduate level, however, they offer Philosophy of Education, Psycho-Philosophical Foundations of Education, Philosophy of Curriculum, and Seminars in Philosophy of Philippine Education, which are being taught by professors equipped to handle the course. ${ }^{27}$

These being said, we cannot expect teachers to efficiently teach reflective thinking to their students because of their lack of training and experience. It would be a challenge to bring Lipman's thoughts into Philippine classrooms precisely because teachers are not fully equipped to take on the task. This is evidenced by the work done by Zosimo Lee.

\section{The State of Community of Inquiry in the Philippines}

Zosimo Lee introduced the practice of reflective thinking in the elementary classrooms and Philosophy for Children after he had attended the Mendham workshop of the Institute for the Advancement of Philosophy for Children (IAPC) in 1996 and in 2000.28 From 1992 to 1996, the faculty members of the Department of Philosophy of the University of the Philippines Diliman were giving lectures on Logic, Epistemology, Metaphysics, and Ethics to the teachers of public schools in Manila, who had initially found philosophy "intimidating and esoteric." 29 This endeavor did not lead immediately to any concrete outcome. In 1996, through the initiative of Dr. Paraluman Giron, the contact was reestablished and the trainings resumed. There were lecture discussions on critical and creative thinking. The teachers proved to be receptive to the ideas because it was at this time that the higher-order thinking was introduced as a requirement in the schools for basic and secondary education. In particular, the teachers of English were the most receptive because they immediately saw the usefulness of the program. They claimed to have been using the pedagogy but did not have the vocabulary for their practice. ${ }^{30}$ Since the concept of higher-order thinking was

\footnotetext{
27 "Academic Programs," in Office of the University Registrar, University of the Philippines, Diliman,http://our.upd.edu.ph/acadprog.php?fbclid=IwAR1LENgmJE8n7g5OyveVvbjof7dxAo pflV5oTXkFdQMPzfy4jibFCgi8KM8.

28 See Zosimo Lee, "Philosophy for Children in the Philippines," in Children Philosophize Worldwide: Theoretical and Practical Concepts, ed. Eva Marshal, Takara Dobashi, and Barbara Weber (Frankfurt: Peter Lang, 2009).

${ }^{29}$ Ibid., 2.

${ }^{30}$ Ibid.
}

(c) 2018 Marella Ada V. Mancenido-Bolaños

https://www.kritike.org/journal/issue 23/mancenido-bolanos december2018.pdf ISSN 1908-7330

(cc) BY-NC-ND 
already introduced to them by the Department of Education (DepEd), they were interested to acquire the skills so they could eventually teach it to their students. The eager teachers realized that "schooling is not always educating, and that educating has to involve enabling their students to become better thinkers." 31 Some of them became critical of their own practice and started to evaluate its philosophical underpinnings. The challenge was that, although the teachers were receptive of the practice, they could not immediately use it in the classroom because of the bureaucracy in their respective schools. Some of them even became "wary of the new techniques and method," reverting back to the feeling that what they were doing was sufficient enough and that there was no need to change or modify it. ${ }^{32}$

Nonetheless, Lee and the other members of the department continued to train public school teachers in Manila for the next two years. The group conducted workshops and regular meetings with teachers in many elementary and secondary schools in Manila. Groups of 25 teachers each began conducting weekly sessions at the Juan Luna Elementary School. For two years the group was able to train 200 teachers, around 35 of whom were convinced to take the second level of further training. Lee noted that "the discussion progressed and certain important debates took place." ${ }^{33}$

The challenge in this program came when the teachers, who were asked to work on their own materials, were not able to comply with the requirement. Lee noted that the teachers might not have learned enough to feel confident about their own work, or they found the task to be difficult. "There was a problem of transfer," Lee said, "in that sense the thinking skills program was not very successful." 34

Moreover, the two-year program was not documented and assessed, and there was no measure to check the impact the "intervention would have on the students." 35 However, in a paper presented by Nancy Sta. Ana, she noted that in 1993 to 1995 :

Statistical data on tests in reasoning and critical thinking before and after using the community of inquiry yielded from $5 \%$ to $12 \%$ increase in scores of pupils. The reasoning/critical thinking test was provided by PNU and was conducted by academic supervisors of English,

\footnotetext{
${ }^{31}$ Ibid.

32 Ibid., 3.

${ }^{33}$ Ibid., 4.

${ }^{34}$ Ibid.

${ }^{35}$ Ibid.
} 
Filipino, and Hekasi supervisors at the beginning and the end of two consecutive school years. ${ }^{36}$

Sta. Ana added that the community of inquiry approach was continuously used by teachers in their language classes, "either as a part of their Reading lessons or as a separate Friday lessons on Philosophy." ${ }^{37}$ At the time of her presentation, she stressed that there were challenges in the implementation of the program. However, she suggested that there may be practical solutions, such as, "teacher mentoring, immersion through guided practice as a participant in a community of inquiry, collaborative partnership with experts, supervised implementation in the teacher's classroom, participation in support system to discuss experiences and pooling of educational resources and materials." 38

Sta. Ana commended the commitment of the practitioners to the program, and to support her claim, she mentioned the achievement of Jesusa Antiquierra of P. Gomez Elementary School who was selected as one of Metrobank's Outstanding Teachers of the Philippines. Antiquierra used the community of inquiry approach in her classes. The award-giving body praised her work saying: "her impact on children is remarkable. Her pupils become an engaging group of reflective, creative, and critical thinkers and philosophers who can identify good reasons, make distinctions and connections, formulate and answer probing questions." 39

Lee, in another article, mentioned that in 2013 there was a renewed interest in the program because of the current shift of the Philippine educational system to K-12. In April 2013, a seminar with Manila public school teachers was conducted and the teachers were immediately convinced that "they should provide this opportunity for their children to develop communities of inquiry." 40

Lee discussed several challenges in the implementation of Philosophy for Children, or P4C, in the Philippines, as follows:

1. Implementation of thinking skill and reflective inquiry program in colleges of education

2. Best practices, models, and paradigms of schools using the Philosophy for Children

\footnotetext{
${ }^{36}$ Nancy Sta. Ana, "P4C: The UP-DepEd Manila Story" (paper presented at the Karunungan Festival 2, O.B. Montessori, Inc., Greenhills, San Juan, 29-30 August 2008).

37 Ibid.

${ }^{38}$ Ibid., 3.

${ }^{39}$ Ibid.

40 Zosimo Lee, "Nurturing Communities of Inquiry in the Philippine Schools," Thinking: The Journal of Philosophy for Children, 20:3-4 (2014), 80.

(c) 2018 Marella Ada V. Mancenido-Bolaños https://www.kritike.org/journal/issue 23/mancenido-bolanos december2018.pdf ISSN 1908-7330
}

(c) BY-NC-ND 
3. Developing instructional materials

4. Training public school teachers in facilitating philosophical dialogue. ${ }^{41}$

As shown earlier, if the curriculum does not foster or cater to the development of thinking skills and reflective inquiry, it would be difficult for teachers to act as models of reflective thinkers since they themselves would not know how to be reflective. In Elicor's recently published article, he notes that "teachers who utilize COI as a pedagogy cannot exercise a hierarchical relation between their intelligence and that of the students." 42 He adds that the teacher must also be open to an intellectual journey with their students and allow himself/herself to be taught, thus, he/she must prod his/her students to dig deeper. ${ }^{43}$ In a way, the teacher must be able to learn and appreciate the shifting of his/her role from being the conveyor of knowledge to being a facilitator of the discussion. Further, the teachers must also be willing to learn from the best practices of the international community of $\mathrm{P} 4 \mathrm{C}$ scholars and practitioners because these could enable them to improve their craft.

Similarly, Kennedy noted that one way of preparing teachers to teach philosophy to children is by making them evaluate their own beliefs and understanding of childhood and the philosophy of childhood. Through this, teachers will gain an understanding of the adult-child relationship which is essential in building a community of inquiry. He also adds that teachers themselves should be engaging in "CPI with each other on an on-going basis, and devoting that inquiry or at least one major dimension of it-specifically to philosophy of childhood." 44

He argues that in understanding childhood, teachers may come across other thoughts which are related to childhood; topics on the human person, human nature, history, literature, technology, and psychology might be brought to fore. Through this kind of critical inquiry teachers are able to "challenge stereotypes and habitual interpretative misunderstanding of children's motives and understanding." 45 Thus, teachers understand the children better and, in the process of engaging with the children, they also realize that some children are doing it better than before, that the children's ear is already becoming more philosophical. ${ }^{46}$ For Kennedy, the teacher's

\footnotetext{
${ }^{41}$ Ibid.

42 Peter Paul E. Elicor, "The Notion of Pedagogical Authority in the Community of Inquiry," Kritike: An Online Journal of Philosophy, 11:2 (December 2017), 90.

${ }^{43}$ Ibid.

44 David Kennedy, "Practicing Philosophy of Childhood: Teaching in the (R)evolutionary Mode", Journal of Philosophy in Schools, 2:1 (2015), 11-14.

${ }^{45}$ Ibid., 9.

${ }^{46}$ Ibid.
}

(c) 2018 Marella Ada V. Mancenido-Bolaños https://www.kritike.org/journal/issue 23/mancenido-bolanos december2018.pdf ISSN 1908-7330 


\section{COMMUNITY OF INQUIRY IN THE PHILIPPINES}

understanding of childhood and the process of CPI (i.e., community of philosophical inquiry) play an important role in the program. Until teachers see the importance and use of CPI, they will not be able to carry on with the program successfully.

Lee argued that the premier schools in the country may have the best facilities and equipment, as well as the most updated collection of books, but the fact remains that the academic practice continues to be unreflective. Teachers still understand teaching as a mere transmission of knowledge without effecting reflection among students. The prevailing method still does not transform students to become active and reflective thinkers. Lee also emphasized that one problem of $\mathrm{P} 4 \mathrm{C}$ in the country is the lack of reading materials. He thinks that students cannot just use Lipman's novels and the other IAPC materials because of their cultural content. Students cannot immediately relate to the texts because the stories are not a part of their worldview. ${ }^{47}$

The development of manuals is important because this is the primary material that can be used to stimulate a community of inquiry. Glenda Oris, another advocate of Philosophy for Children, answered to this call. She has authored a number of children's books, such as Looking out for Heroes; Kwento ng Isang Mambabasa (A Reader's Story); Whuush!; Ang Madyik ni Paolo; Ayun, O! Handaan; Ayun, O! Surpresa; Ayun, O! Laro Tayo!; Ayun, O! Bakasyon na!; and Ayun, O! Pasukan na! In her presentations, Oris makes use of her books as stimulus for a community of inquiry. Her involvement in the program started when she was invited to present a paper during the 15th International Council of Philosophical Inquiry with Children (ICPIC) Conference held in Jinju, South Korea, in July 2011. After the said conference she became one of the two representatives for the Philippines; the other one is Rainier Ibana, who is currently the President of Philosophy for Children and Youth Network for Asia and the Pacific. Since then, she has become a regular speaker in the UNESCO-sponsored conferences organized annually by Ibana and his team.

Looking at the possible contribution of Filipino philosophers to the program, Lee says, "[T]hey can provide intellectual ramparts and guidance that will allow such a process to reach maturity and fruition." 48 Filipino philosophers must look at the program as an opportunity to help in transforming the conduct of classes by making it reconstructive and reflective. This initiative must spring from an authentic desire and the sincerity to support students and teachers who are just learning how to conduct a community of inquiry. Training public school teachers to facilitate

\footnotetext{
${ }^{47}$ Lee, "Philosophy for Children in the Philippines," 15.

${ }^{48}$ Lee, "Philosophy for Children in the Philippines," 9.
} 
a philosophical dialogue is a challenging task inasmuch as a number of them tend to resist the new method and question its efficiency, insisting that the old practice is just as good.

To date, there is a growing number of Filipino philosophers who are willing to take part in training in-service teachers to do reflective thinking in their respective classes. Abigail Thea Canuto of the University of the Philippines wrote her thesis on "Critical Thinking and 'Philosophical Progress' in Dialogues of Grade Two Children in a Community of Inquiry." 49 She also handles philosophy courses at the UP College of Education where she uses the community of inquiry as a pedagogy. Rowena Azada-Palacios started training with Society for the Advancement of Philosophical Enquiry and Reflection in Education (SAPERE) in 2015. She attended trainings in the UK, Singapore, and Korea and already completed the SAPERE level 3 training. To date, she has trained approximately 400 teachers, some have utilized the community of inquiry in their classes. Moreover, she also uses the community of inquiry in her philosophy classes at the Ateneo de Manila University and according to her, she has students from the teacher education program who were able to utilize it in their respective classes as well.

Maria Lovelyn Corpuz-Paclibar and Mark Joseph Calano from Ateneo de Manila University were also able to train with Philosophy with Children and Youth Network for Asia and the Pacific in 2015, and Peter Paul Elicor of Ateneo de Davao University in 2017. Leander Marquez and Cathryne Joy Alvarez of the University of the Philippines, and Marella Ada Mancenido-Bolaños of the University of Santo Tomas attended the 2017 Residential Workshop with the IAPC in Mendham, New Jersey.

Marquez and Alvarez handle the National Service Training Program of the University of the Philippines. In this program, they train college students to facilitate a community of inquiry during the first semester in preparation for their 45-hour community engagement during the second semester at the San Vicente Elementary School in Diliman, Quezon City. Marquez notes that the administrators, teachers, and students of San Vicente Elementary school are very receptive to the practice, and the principal is even willing to enter into a contract with them for the continuity of the said program. ${ }^{50}$

Peter Paul Elicor of Ateneo de Davao University facilitates classes with some indigenous ethnic groups and other marginalized students in Mindanao. Meanwhile, Marella Mancenido-Bolaños, together with Fleurdeliz Altez-Albela and the undergraduate philosophy students of the

49 Abigail Thea O. Canuto, “Critical Thinking and 'Philosophical Progress' in Dialogues of Grade Two Children in a Community of Inquiry" (M.A. Thesis, University of the Philippines, April 2013).

${ }^{50}$ Leander Marquez, correspondence with author, August 2018.

(c) 2018 Marella Ada V. Mancenido-Bolaños https://www.kritike.org/journal/issue 23/mancenido-bolanos december2018.pdf ISSN 1908-7330 


\section{COMMUNITY OF INQUIRY IN THE PHILIPPINES}

University of Santo Tomas, facilitates community of inquiry classes with the alternative learning system students of Juan Luna Elementary School.

The community of inquiry is consistently used by teachers from Ayala Foundation, Inc.'s partner schools. Teachers are continuously trained and monitored by the foundation to ensure that they are able properly utilizing the practice in their respective classes.

\section{Putting Theory into Practice: Community of Inquiry in CENTEX Schools}

In 2012, Lee introduced Philosophy for Children to the Center of Excellence in Public Elementary Education (CENTEX) through the initiative of Ayala Foundation, Inc. (AFI). The outcome of the workshop is the foundation's implementation of the community of inquiry in their partner schools, particularly CENTEX Manila and Batangas. ${ }^{51}$ CENTEX operates in Tondo, Manila and Bauan, Batangas. This project, which is a partnership between DepEd and AFI, started operating in 1998, and since then 634 students have graduated from both schools. ${ }^{52}$

During several meetings and school visits, the author was able to observe an actual COI (community of inquiry) session in CENTEX Manila. The author was able to observe four classes that consistently used the community of inquiry in the conduct of their lessons: Kindergarten, Grade 1, Grade 2, and Grade 5. The author was also able to interview the teachers of these respective classes and selected $5^{\text {th }}$ graders who have been immersed in the program for the longest time.

The conversations with the $5^{\text {th }}$ graders revealed that they liked the program. They emphasized that it changed their views about learning because they had realized that there could be a better way of learning. They appreciated the fact that in the COI there are no definite answers, and everyone can speak their minds without fear of being judged by their classmates. They liked the fact that friendship grew in their class because they eventually learned about the background of their classmates. Students who were able to understand the lesson faster helped the others to understand the more difficult topics. The discussions were not focused only on the more intelligent students in the class, because even the slow learners are given the opportunity to speak.

According to Student A, the community of inquiry changed his view about learning. He realized that "there's something more than being on top of this school ... with the community of inquiry, I feel like I have more

\footnotetext{
51 "CENTEX," in Ayala Foundation

http://www.ayalafoundation.org/program/centex/.

52 Ibid.

(C) 2018 Marella Ada V. Mancenido-Bolaños

https://www.kritike.org/journal/issue 23/mancenido-bolanos december2018.pdf

ISSN 1908-7330
}

(c) $)$ BY-NC-ND 
freedom to express what I want ... you can say that in a community of inquiry, there is no right or wrong answer because it is their opinion." Meanwhile, Student B notes that learning has become more interesting since they started using COI in their class.

The teachers interviewed were very receptive to the program. They are convinced that the community of inquiry has changed their perspective on teaching. According to a grade 5 teacher, in the traditional method, the questions would usually come from her in an effort to help the children understand the topic being discussed. Through COI, however, she realized that children have "varied ideas, if you just allow them to express what they think .... That is, when they learn to be very expressive and articulate on what their thoughts are." She added that the program helped in the development of the children's critical thinking, and that the students were able to develop concepts analytically. She noted that when she was still using the traditional method of providing questions to the students, the discussions were shallow because the class was not able to thoroughly explore the topics; but when she began using COI in her classes, she noticed that the children's line of questioning became critical such that they would now know how to put themselves in the place of the characters in the story.

The author had the chance to observe the conduct of her class and noticed that there were students who were able to facilitate their group. The student facilitators were already able to classify the questions, asking the members of the group which questions were to be addressed first. The students were able to synthesize the discussions and challenge one another's ideas. There were even instances when the children resorted to using the COI even outside the classroom.

The $5^{\text {th }}$ grade teacher recommends that the practice be a continuous one. According to her, if it has been introduced to kindergartners in their English class, it should be possible also to use it in the other subject areas, such as science and math. It should also be practiced at each year level to maximize learning. One of the problems they encountered, however, is that the pedagogy is sometimes used by a teacher in a particular year level, but when the students reach the next year level the new teacher opts for a different method in her class. There is no continuity in the process, thus, they are not able to maximize the development of the students' thinking skills.

With the discussions cited above, it is evident that the students are able realize their ability to generate knowledge. The interview with the students is proof that the students trusted the whole process, they know that they are building on one another's ideas and that they are learning from one another.

In 2017, preschool teachers from Jacinto Zamora Elementary School were also able to bring the practice to their school. AFI recommends that this

(c) 2018 Marella Ada V. Mancenido-Bolaños https://www.kritike.org/journal/issue 23/mancenido-bolanos december2018.pdf ISSN 1908-7330 


\section{COMMUNITY OF INQUIRY IN THE PHILIPPINES}

group of preschool teachers be allowed to teach in first grade during the next academic year to be able to handle the same class they handled during this academic year. This would allow the teachers to follow up on the students' progress.

In a conversation with the AFI's project coordinators, they cited several problems that they encounter in the implementation of the program. They noted that teachers tend to be consumed by the objectives set in their lesson plans as mandated by DepEd that they feel the urge to accomplish it rather than focus on the proper delivery of COI in their respective classes. They were also having difficulty in convincing DepEd to, once and for all, consider P4C training as a valid training that could be credited. The foundation wishes to develop the program further by looking into indicators of success for both teachers and students. They wanted to come up with a measure or rubric for this, because such an instrument can help them convince DepEd to adopt the CENTEX model. Lastly, they want to apply with National Educators Academy of the Philippines (NEAP) for the validation of the Training Institute curriculum and the accreditation of their training hours so that teachers will be encouraged to attend the training and eventually implement the program in the classroom.

\section{Conclusion}

There is still a difficulty in implementing the program in the Philippines as discussed by Lee in his articles. However, there is a consistent growth in the number of scholars who are willing to train basic education teachers and work with public school teachers in implementing the program. There is also a growth in the number of teachers who are convinced to use the pedagogy in their respective classes. The democratic practice in the Philippine educational system where priorities of the DepEd shifts every time a new president is elected contributes to the difficulty in implementing the program. In addition, the priorities set by Division Heads is also an issue. DepEd still adheres to the traditional method of knowledge transfer from teacher to student and is still resistant to new methods.

With the introduction of outcomes-based learning in the country where students are required to produce tangible projects as part of their performance tasks, the idea of allowing students to engage in a community of inquiry in class becomes unimaginable as teachers are not trained to have an ear for philosophical discussions that might ensue in class. According to the Department of Education (February 2018), in Metro Manila alone, there are 517 public elementary schools, 247 public secondary schools, 1,495 private preschools, 1,304 private elementary schools, and 820 private secondary schools that cater to two million students in the region. To be able to convince 
the Division Head to train the teachers in the region and to finally implement it in their classes is a big challenge.

Lipman, Oscanyan, and Sharp in Philosophy in the Classroom (1980), notes that people are predisposed to think that the problem lies in the fact that "many children today are bored and apathetic, and that this is a direct result of their home environment." 53 However, they argue that no matter how little children are stimulated at home, when they enter kindergarten they are curious and very eager to learn. When they reach their third grade, their inquisitiveness starts to dissipate and, by the time they reach middle school, they feel simply compelled to stay in school. Lipman suggests that schools must help children find meanings relevant to their lives. Schools must be able to establish opportunities which will enable children to sustain their curiosity. Teachers may once again argue that they are already doing this in their classrooms. Lipman insists that children must be taught to think as thinking enables us to acquire meaning. ${ }^{54}$

One of the reasons why students are not trained to think reflectively is because even their teachers have not been trained to do reflective thinking. As a result, they lack the creativity to stimulate the minds of the students. Says Lipman, "The problem of method in forming habits of reflective thought is the problem of establishing conditions that will arouse and guide curiosity; of setting up connections in the things experienced that will on later occasions promote flow of suggestions, create problems and purposes that will favor consecutiveness in the succession of ideas." 55

It is clearer now that there is a need to revisit the teacher education curriculum in the Philippines. As long as we do not change the way we look at how teachers are being trained, the case will remain the same. We cannot expect teachers to change their practice unless they have been well-grounded in theory and in reflective, inquiry-based practice. It is when they are able to understand the philosophy behind each pedagogical method will they be able to gain full appreciation of the practice.

Department of Philosophy, University of Santo Tomas, Philippines

\section{References}

Bernardo, Allan B.I., “Learning about Learning: Cognitive Processing Constraints in Teacher Educators Developing New Understanding about Learning and Pedagogy and How to Overcome Them," in

\footnotetext{
${ }^{53}$ Lipman, Oscanyan, and Sharp, Philosophy in the Classroom, 12.

54 Ibid., 12-13.

${ }^{55}$ Lipman, Thinking in Education, 2.
}

(c) 2018 Marella Ada V. Mancenido-Bolaños https://www.kritike.org/journal/issue 23/mancenido-bolanos december2018.pdf ISSN 1908-7330 
156 COMMUNITY OF INQUIRY IN THE PHILIPPINES

Ripples of Change: A Journey of Teacher Education Reform in the Philippines (Quezon City: Commission of Higher Education, 2007).

Canuto, Abigail Thea O., "Critical Thinking and 'Philosophical Progress' in Dialogues of Grade Two Children in a Community of Inquiry," (M.A. Thesis, University of the Philippines, April 2013).

"Values Education for a Democratic Society" (paper presented during the Seminar/Workshop on Values Education, Philosophy of the Human Person, Media Values and Society in the K-12 and Senior High School Context, University of the Philippines, Diliman, Quezon City, 3 December 2016).

"CENTEX," in Ayala Foundation http://www.ayalafoundation.org/program/centex/.

Elicor, Peter Paul E, "The Notion of Pedagogical Authority in the Community of Inquiry," Kritike: An Online Journal of Philosophy, 11:2 (2017).

Kennedy, David, "Practicing Philosophy of Childhood: Teaching in the (R)evolutionary Mode," Journal of Philosophy in Schools, 2:1 (2015).

"The Community of Inquiry and Educational Structure," in Thinking Children and Education, ed. by Matthew Lipman (Dubuque, IA: Kendall/ Hunt Publishing Company, 1993).

Lee, Zosimo, "Nurturing Communities of Inquiry in the Philippine Schools," Thinking: The Journal of Philosophy for Children, 20:3-4 (2014).

"Philosophy for Children in the Philippines," in Children Philosophize Worldwide: Theoretical and Practical Concepts, ed. by Eva Marshal, Takara Dobashi, Barbara Weber (Frankfurt: Peter Lang, 2009).

Lipman, Matthew, Lisa (New Jersey: Institute for the Advancement of Philosophy for Children, 1983).

Philosophy Goes to School (Philadelphia: Temple University Press, 1988).

Thinking in Education (New York, NY: Cambridge University Press, 2003).

Lipman, Matthew, Fredrick Oscanyan, and Ann Margaret Sharp, Philosophy in the Classroom (Philadelphia, PA: Temple University Press, 1980).

Payongayong, Ma. Theresa T., "Creating a Community of Inquiry through Philosophy," Transactions of the National Academy of Science and Technology Philippines, 29 (2007).

Sta. Ana, Nancy, "P4C: The UP-DepEd Manila Story," (paper presented at the Karunungan Festival 2, O.B. Montessori, Inc., Greenhills, San Juan, 2930 August 2008).

Vansieleghem, Nancy and David Kennedy, "What is Philosophy for Children, What is Philosophy with Children-After Matthew Lipman?" Journal of Philosophy of Education, 45:2 (2011).

(C) 2018 Marella Ada V. Mancenido-Bolaños

https://www.kritike.org/journal/issue 23/mancenido-bolanos december2018.pdf

ISSN 1908-7330

(cc) BY-NC-ND 


\section{Maclntyre, Alasdair, Ethics in the Conflicts of Modernity: An Essay on Desire, Practical Reasoning, and Narrative ${ }^{1}$}

Jovito V. Cariño

Imost a decade after his last book (God, Philosophy, Universities: A
Selective History of Catholic Philosophical Tradition, 2009) Alasdair
MacIntyre has once more graced his readers with an opus poised to equal, if not surpass, his now classic work, After Virtue (1981). Quite frankly, it is very tempting to take this latest offering from the Scottish-American philosopher as an updating of his reconstruction of Aristotelian ethics which he proposed, via the aforementioned magnum opus, as a philosophic remedy to mitigate the interminable moral disagreements spawned by modernity. Anyone with adequate familiarity with the MacIntyrean literature would not miss a sense of both continuity and contiguity between the present text and the themes developed elsewhere by MacIntyre. Its comparative worth notwithstanding, the book easily qualifies as a stand-alone reader which could be conveniently enjoyed either by an avid MacIntyrean or a newbie who forays into his oeuvre for the first time. In other words, while an exposure to MacIntyre's writings could be of help, in particular, his critique of modern ethics, its absence by no means poses a barrier to the uninitiated given MacIntyre's proclivity to write in his usual pedagogic, magisterial style. Simply put, the text at hand, like most materials authored by him, is a testament to that rare virtue among philosophers, especially the great ones, to give their thoughts an organic structure, clarify their premises, hint at their conclusions, define their terms and provide transition segments which would allow the reader to sustain his attention in between narrative and conceptual shifts. This indeed is a positive feature but something that is not without paradox considering MacIntyre's avowed aversion to ethics' unfortunate decadence into a field of academic philosophy. As in his other writings, MacIntyre, in this particular book, raises his concern against ethics' narrowing into a compartmentalized knowledge domain under the watch of the so-called experts - theorists, professors, researchers, consultants-who

${ }^{1}$ Cambridge, UK: Cambridge University Press, 2017, 322pp.

(C) 2018 Jovito V. Cariño

https://www.kritike.org/journal/issue 23/carino december2018.pdf

ISSN 1908-7330

(cc) BY-NC-ND 


\section{ETHICS IN THE CONFLICTS OF MODERNITY}

are able to devise a system that explains and resolves every imaginable ethical question but excludes in the process the very person from whom it comes and for whom it matters. Referring to the difficulty of overcoming the depth of philosophic disagreements among modern ethics' schools of thought, MacIntyre inquires: "Does the impasse at which I arrived perhaps result from the nature and limitation of such enquiry, enquiry that is narrowly academic? ... Yet what the compartmentalization of contemporary social life ensures is that those who do have these important life experiences in armies or factories, or farms, or prisons, or whatever are generally educated, just as professional philosophers are, to believe that philosophical reflection and enquiry are matter for academic specialists and not for them. Perhaps, however, at least so far as moral and political philosophy are concerned, this is a mistake. Perhaps philosophers need to begin from everyday questions of plain persons, the plain persons that they themselves were before they took to the study of philosophy." 2 Among the many attributes adopted from both Aristotle and Aquinas, it is perhaps this insistence on the unique and inalienable capacity of the ordinary person to reason and act ethically in pursuit of what is good which marks MacIntyre for me as a compelling Thomistic Aristotelian thinker. Both Aristotle and Aquinas believe that a human person is an ethical agent who has it in her the impetus to engage in rational practices such as inquiry and deliberation in view of her progressive attainment of human flourishing. The exclusion of the average person coincides with modernity's estrangement of reason from the moral debates which weigh down our culture today. The interminable character of these debates, however, is definitely, for MacIntyre, not a reason to lose hope. While there may not yet be a painless end to these debates in sight, his reconstructive Thomistic Aristotelian scheme assures us that we are never out of options.

Department of Philosophy, University of Santo Tomas, Philippines

${ }^{2}$ Ibid., 70-71.

(c) 2018 Jovito V. Cariño

https://www.kritike.org/journal/issue 23/carino december2018.pdf

ISSN 1908-7330

(c) $)$ BY-NC-ND 


\section{Submissions}

\section{Please Read Carefully}

\section{A. What do we publish?}

We are interested in publishing articles, review articles, book reviews, and creative works across the whole range of philosophical topics, but with special emphasis on the following subject strands:

- $\quad$ Filipino Philosophy

- $\quad$ Oriental Thought and East-West Comparative Philosophy

- Continental European Philosophy

- Anglo-American Philosophy

The journal primarily caters to works by professional philosophers and graduate students of philosophy, but welcomes contributions from other fields (literature, cultural studies, gender studies, political science, sociology, history, anthropology, economics, inter alia) with strong philosophical content.

\section{B. How long should a submission be?}

- $\quad$ Article (8,000 words or less)

- $\quad$ Review Article (8,000 words or less)

- Book Review (2,500 words or less)

\section{When should you submit your work?}

Because of the sheer number of unsolicited submissions we receive every day, submission management has become a challenge for us. This often results in the piling-up of submissions, the breakdown of the online submission tool, and, at times, unacknowledged submissions. Therefore, we have devised a scheme to help us manage unsolicited submissions.

- $\quad$ Submissions for the June issue will be entertained ONLY during the January-February period (March-May for the refereeing process)

- $\quad$ Submissions for the December issue will be entertained ONLY during the July-August period (September-November for the refereeing process)

\section{Specific Submission Guidelines}

1. Submissions may be in either English or Filipino with good punctuation, grammar, and spelling. Provide a 200 word abstract in English and at least 4 key words. Please take note of the number of the acceptable word count for your submission (see Section B above).

2. KRITIKE is a refereed journal, so make sure that your text is prepared for blind review, meaning your name and institutional affiliation should not appear in the body of your paper. If you cited your own previous work(s) in the article, delete your name from the citation(s).

3. We recommend that, at the first instance, you use our prescribed citation style. You may also use the Chicago style which resembles our own. $\underline{\text { Click }}$ here to visit the journal's style guide page.

4. Submit your text in 2.0 line spacing with 12 points font size. Quotations exceeding four lines should be indented and single-spaced.

5. Save your paper as either a Rich Text Format file (*.rtf) or a Microsoft Word document (*.doc or *.docx).

6. We recommend that you submit your paper by filling in the online submission tool at the right column of the submissions page for a more systematic and efficient submission process.

7. We have amended our submission management policy (see Section C above). Submissions entered through the online submission tool outside the specified periods in Section C will not be considered. We recommend that you resubmit your work during a specific submission period.

8. By sending us your submission, you agree to be bound to the Terms and Conditions set in Section C of the journal's Publication Ethics and Publication Malpractice Statement. 


\section{Publication Ethics and Malpractice Statement}

KRITIKE is committed to meet the highest ethical standards in research and academic publication. The journal is guided by the following principles:

\section{A. Responsibilities of the Editorial Board}

The Editorial Board ensures that manuscripts are prepared for blind peer-review. It is the responsibility of the Editorial Board to accept, reject, or recommend a manuscript for revision and resubmission. Such decision is based, to a large extent, on the recommendations of nominated experts who act as referees. It is the responsibility of the Editorial Board to inform an author about the status of his/her submission, regardless of the decision. The Editorial Board may choose to reject a paper that violates legal provisions on libel, copyrights, and originality (plagiarism). Information regarding a manuscript under review must remain confidential until it is finally accepted for publication. The Editorial Board does not necessarily endorse the views expressed in the articles published in the journal. As an Open Access journal in the Gold category, KRITIKE does not charge any fees to complete the publication process. No charges are levied against the authors or users for submission or article processing.

\section{B. Responsibilities of the Referee}

The referees nominated by KRITIKE's Editorial Board are experts in their areas of specialization. The referees assist the Editorial Board's decision to accept, reject, or revise and resubmit manuscripts based on their objective assessments and recommendations. A referee must treat an assigned manuscript with utmost confidentially during the peer review process; however, it is the responsibility of the referee to inform the Editorial Board when a legal violation by the author is suspected. The evaluation of a manuscript should be based solely on its academic merit and not on race, gender, sexuality, or religious and/or political orientation of the author.

\section{Responsibilities of the Author}

It is the responsibility of the author to prepare his/her manuscript for blind review. The author must ensure that his/her work is original and not plagiarized. The sources used in the manuscript should be properly cited. An author must not submit the same manuscript to another journal when it is currently under review by KRITIKE. It is the responsibility of an author to inform the Editorial Board right away if his/her manuscript is being considered in another journal or publication medium; in such case, KRITIKE will discontinue the review of the manuscript. If an author's manuscript is published by KRITIKE, he/she must adhere to the provisions set in the Copyrights section of the journal 
If you wish to send us your feedback, general questions about the journal, questions about article submissions, theme suggestions for future issues, or word of intention to be a peer-reviewer or referee, send a message to kritike.editor@gmail.com.

If you wish to be a peer-reviewer or referee, do send us your complete name, e-mail address, institutional affiliation, position, and area of expertise via e-mail (include subject heading: reviewer). If you have any suggestions for specific themes (e.g., "European Philosophy and the Filipino Mind” or "Is there such thing as Filipino Philosophy?") for future issues of the journal, send them via (include subject heading: theme).

Please note that unsolicited submissions should be sent through the journal's Article Submission Tool.

You can also contact us via snail mail:

\section{KRITIKE}

\section{c/o Dr. Paolo A. Bolaños}

Department of Philosophy

Room 109 Main Building

University of Santo Tomas

España, Manila 1015

Philippines 